\title{
THE HIGHER CLASSIFICATION OF THE LYCAENIDAE (LEPIDOPTERA): A TENTATIVE ARRANGEMENT
}

BY

\section{JOHN NEVILL ELIOT}

Upcott House, Bishop's Hull, Taunton, Somerset

Pp. 37I-505 ; 6 Plates ; 162 Text-figures

\begin{abstract}
BULLETIN OF
THE BRITISH MUSEUM (NATURAL HISTORY) ENTOMOLOGY Vol. 28 No. 6
\end{abstract}

LONDON 1973 
The BUlletin OF The BRitish MUSEUM (NATURAL HISTORY) instituted in I949, is issued in five series corresponding to the Departments of the Museum, and an Historical series.

Parts will appear at irregular intervals as they become ready. Volumes will contain about three or four hundred pages, and will not necessarily be completed within one calendar year.

In I965 a separate supplementary series of longer papers was instituted, numbered serially for each Department.

This paper is Vol. 28 No. 6 of the Entomological series. The abbreviated titles of periodicals cited follow those of the World List of Scientific Periodicals.

World List abbreviation

Bull. Br. Mus. nat. Hist. (Ent.).

(C) Trustees of the British Museum (Natural History), 1973

TRUSTEES OF

THE BRITISH MUSEUM (NATURAL HISTORY) 


\title{
THE HIGHER CLASSIFICATION OF THE LYCAENIDAE (LEPIDOPTERA): A TENTATIVE ARRANGEMENT
}

\author{
By J. N. ELIOT
}

\section{CONTENTS}

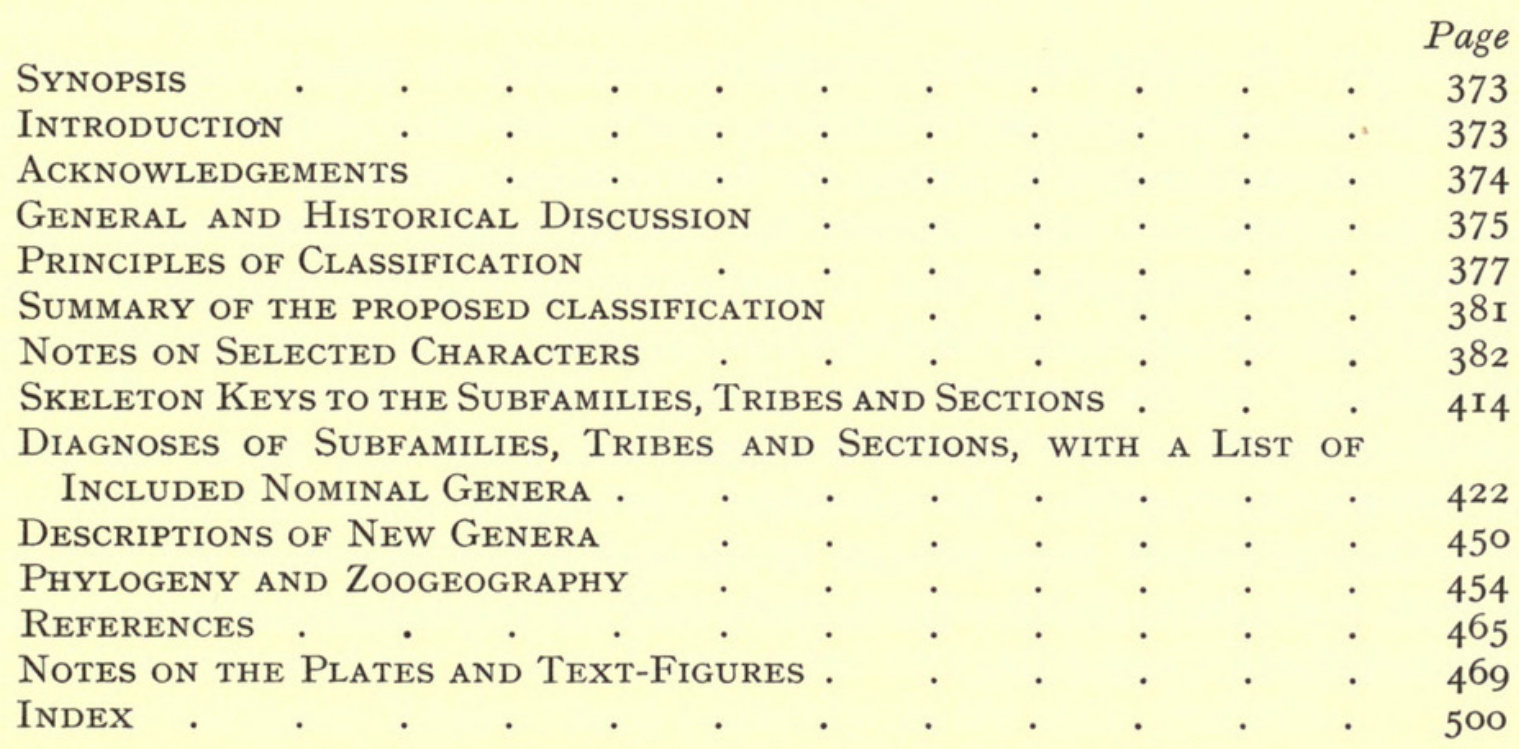

SYNOPSIS

A tentative reclassification is proposed for the Lycaenidae on the basis of the male genitalia, characters of the head, legs and wings, secondary sexual characters and an imperfect knowledge of the early stages. Keys are given to the subfamilies, tribes and sections. All the nominal genera are listed under their respective subfamilies, tribes and sections. Eight new tribes and seven new genera are described; one new generic name is proposed to replace a junior homonym. An attempt is made to reconstruct the phylogeny and zoogeographical history of the family.

\section{INTRODUCTION}

For many years, intermittently and in my spare time, I have been investigating the Oriental Lycaenidae in the hope that ultimately I might prepare keys to all the Oriental species, somewhat on the lines of Evans's well-known keys to the Hesperiidae of the World, and in the belief that such a work would be useful to the growing number of collectors in South-East Asia. In order to provide a framework and logical sequence for such keys I deemed it necessary to start by working out a higher classification; but although the Oriental Lycaenid fauna exceeds that of other regions in richness and variety, it proved impossible to do this in isolation and I found myself drawn into a study of Lycaenidae from other regions. My interest becoming 
increasingly aroused, I decided to extend my examination in outline to the whole world, though it was only after considerable misgivings that I decided to include the Neotropical genera and the wholly African subfamily Lipteninae. I had no personal experience of either group in the field and therefore lacked the confidence imparted by the feeling of 'knowing one's butterflies'. However Riley (I956) had already pointed out that the Neotropical 'Theclas', despite their numbers and varied appearance, were remarkably homogeneous in male genitalia and venation, whilst in the case of Lipteninae it was clear that the groundwork had already been completed by Stempffer during almost a lifetime of meticulous research, supplemented by the work of such experts as Bennett, Clench, Jackson and Roche. I therefore decided to carry out a limited examination of these groups, confined to the typespecies or, in the case of polytypic genera, to representative species of the apparent species-groups. It might well be thought imprudent to base a classification on such limited evidence, especially if differing much from that proposed by Stempffer. However, I felt encouraged to persist for two reasons. Firstly, Clench (I965) had proposed an alternative classification for the Ethiopian Region differing quite substantially from Stempffer's, and it seemed to me that when experts disagreed it was open, and perhaps even valuable, for a layman to act as umpire or to venture a third opinion. In the second place Stempffer had himself expressed the wish that his ideas should attract fruitful criticism; and I can only hope that my ideas are not wholly destructive. In the event my classification approximates more closely to that of Clench than to that of Stempffer, but this does not in any way detract from my admiration for the latter's outstanding contribution to our knowledge of the African Lycaenidae.

\section{ACKNOWLEDGEMENTS}

I wish first to thank the Trustees of the British Museum (Natural History) for permission to make use of the collections and library, and the many members of the Museum staff who helped me in one way or another. Whilst the work was in progress the Lycaenidae were housed at Tring, and I must therefore single out for especial gratitude Messrs G. E. Tite and N. H. Bennett and Miss S. J. May, past or present members of the Tring staff, for much patient assistance given ungrudgingly. I am also greatly indebted to Mr R. I. Vane-Wright, in charge of the butterfly collections, for encouragement and for his painstaking examination of Lycaenid scales under the scanning electron microscope. The following gentlemen kindly read the whole or part of my paper in draft, and many of their criticisms and suggestions are incorporated in the final text: Lt.-Col. C. F. Cowan, Messrs N. D. Riley, R. I. Vane-Wright, G. E. Tite, N. H. Bennett, J. D. Holloway, H. Stempffer and H. K. Clench. It was a particular pleasure to receive comments from the two last-named gentlemen, since their own very extensive work on the Lycaenidae has, to a considerable extent, provided the foundations on which my work is based. I wish to thank Dr A. Sibatani, of Lindfield, N.S.W., for a most helpful discussion on the systematics of the Australian genera and for information on their early stages. Mr D. Sands also kindly provided me with information on the early stages 
of Australian species, and Mr L. E. Couchman gave me his views on the interrelationships of the Australian genera. Dr A. Kapur, Director of the Zoological Survey of India, kindly arranged for the dissection of the unique holotype of Listeria dudgeoni de Nicéville and sent me drawings of its head and genitalia. Major A. Bedford Russell put his collection of Neotropical Lycaenidae at my disposal. Finally I must express my debt to the many previous workers in this field, on whose discoveries I have drawn. If I have not always given them their full due, this is unintentional; the butterfly literature is so vast that it is inevitable that I have overlooked much important work.

\section{GENERAL AND HISTORICAL DISCUSSION}

So far no author has produced a satisfactory classification of the whole of the Lycaenidae, although a notable step in this direction was taken by Clench (I955, amended I965). Other important works in a more limited field are by Toxopeus (I929), who erected a number of new subfamilies, tribes and genera, but without a diagnosis of their characters which was to follow in a later, but unfortunately never published, paper; by Evans (I932, amended by Cantlie, I963), whose keys to the Indo-Burmese genera, based on easily seen external characters, include some artificial groupings; by Riley (I956), who investigated the male genitalia of the tribes and genera of the Holarctic Theclinae; by Shirôzu \& Yamamoto (I956), whose revision of the tribe Theclini, using a variety of characters, is a model of careful analysis; and finally by Stempffer (I957, I967), who in a monumental work on the genera of the African Lycaenidae sets out a tentative higher classification for the Ethiopian Region based primarily on the male genitalia.

In the above works the categories family, subfamily and tribe carry different weight. Indeed the first difficulty which faces any would-be systematist is the fact that no standard criteria have been laid down by which he may decide the limits of each sub-division. Some twenty years ago the family Lycaenidae was generally accepted as a group of approximately equal status with the Riodinidae ${ }^{1}$ within the superfamily Lycaenoidea. However, Clench (I955) divided the former into three families co-equal with the Riodinidae, namely Lycaenidae (sensu stricto), Liptenidae and Liphyridae. Shirôzu \& Yamamoto (I957) added a further family Curetidae. On the other hand Ehrlich (I958, I960), on the basis of many, mainly internal characters, proposed the reduction of the Lycaenoidea to the status of a single family with three subfamilies: Riodininae, Styginae (for the single species, Styx infernalis Staudinger) and Lycaeninae, the last-named including Lycaenidae (sensu Clench), Liptenidae, Liphyridae and Curetidae. I reject so drastic a downgrading as that proposed by Ehrlich, and recognize that there are advantages in upgrading numerically large groups into families, as proposed by Clench, since this facilitates their further subdivision using only the generally accepted categories of subfamily, tribe, genus and subgenus. At the same time I recognize that Ehrlich

\footnotetext{
1The family-group name Riodinidae is used advisedly, pending the outcome of an application by Cowan to the International Commission on Zoological Nomenclature for its retention in preference to at least five earlier available family-group names.
} 
was correct in his view that the four 'families' Lycaenidae (sensu Clench), Liptenidae, Liphyridae and Curetidae all have more characters in common with one another than with Riodinidae or Stygidae, particularly in respect of the widely used family characters of antenna and male foreleg. For this reason I prefer to treat the first four as the single family Lycaenidae, thus restoring to this name its former meaning, even though I very tentatively suggest later (pp. 460-46I) that this taxonomic arrangement may conceivably reflect a false phylogenetic history.

I consider that the category subfamily should be restricted to the major branches of the family tree. Unfortunately this leaves only the categories tribe, genus, subgenus and species for the various minor branches, branchlets, twigs and twiglets, unless one multiplies the subgeneric categories, as for example was done by Munroe (I960) in his classification of the Papilionidae, by introducing sections, subsections, series and species-groups between the subgenus and the species. Such multiplication of minor categories is, I think, rather confusing and I prefer the concept of supertribes and subtribes and, whilst accepting the subgenus as a valid taxonomic concept, deplore its use in practice because of the lengthening of nomenclature involved. Unfortunately the International Code of Zoological Nomenclature does not recognize a separate suffix to distinguish supertribes and subtribes from tribes, and these terms are therefore best avoided. For this reason I equate supertribes with subfamilies and designate subtribes as sections under the name of an included genus, e.g. the Dapidodigma section of Cheritrini.

On this basis I recognize Curetidae (sensu Shirôzu \& Yamamoto) and Liptenidae (sensu Clench) as valid subfamilies, except that I remove the genus Thestor from the latter. Clench divided his family Liphyridae into three subfamilies: Liphyrinae, Gerydinae (which Corbet (I939) had previously replaced by Miletinae) and Poritiinae, but the last-named was only included with some reservation. The rather isolated position of Poritiinae was recognized by Toxopeus (op. cit.), who removed them to Riodinidae, where they occupy a still more anomalous position. Both in their immature and adult stages, as I shall show later, their affinities lie with Lipteninae, the distinction being of supertribal order. I treat them for convenience as a subfamily; if they were to be merged with Lipteninae the name Poritiinae would take priority under the Code. I agree with Clench that Liphyrinae and Miletinae are fairly closely related, the distinction being of supertribal order. I retain both as subfamilies; if they should be merged the name Miletinae would take priority. Clench subdivided his family Lycaenidae (sensu stricto) into a number of groups based chiefly on characters of the legs and the presence or absence of a juxta in the male genitalia. This restricted approach led him into many wrong conclusions, a fact which he recognized as highly probable at the time. I regard the whole assemblage, comprising perhaps 90 per cent. of the family (sensu lato) as of subfamily status. Unfortunately it has been subdivided in the past eighty years into numerous so-called subfamilies, including many of an artificial character. The best natural grouping, of supertribal order, is the traditional popular trinity o'Blues', 'Coppers' and 'Hairstreaks', and I accept these as the subfamilies Polyomf matinae, Lycaeninae and Theclinae respectively. The above ideas can be expressed by the following simple diagram:- 


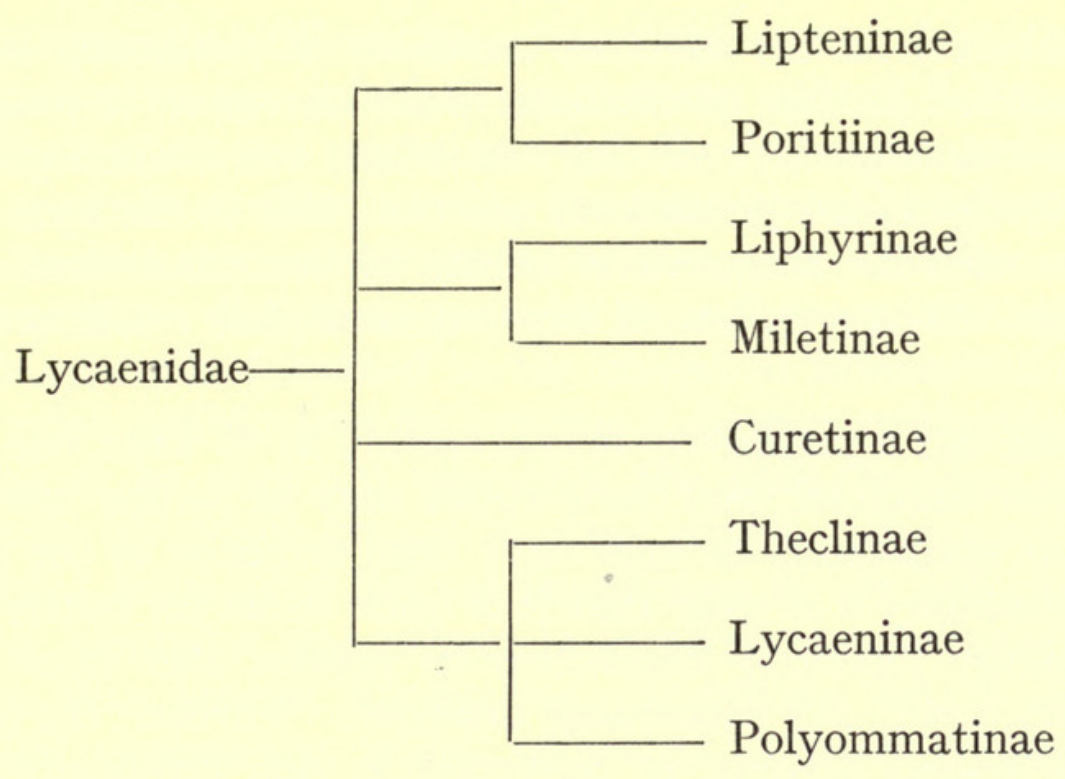

PRINCIPLES OF CLASSIFICATION

In deciding on my classification I have been guided by the principles discussed below.

I. As many characters as possible should be used.

This principle is generally accepted, but a different view has been expressed by Warren (I947), who attempted a classification of the butterflies based on what he called true and complementary characters. Stempffer (I967) has already pointed out that Warren's characterization of the Lycaenidae needs considerable qualification, and when it is examined on a world-wide basis it is found that the true and complementary characters which Warren uses to key out the Lycaenidae are, by his own definition, false characters (i.e., characters which have neither a recognizable frequency of occurrence nor stability of combination and can often be found among members of other units). The conclusion seems obvious. At least at family and lower level it is the combination of many characters that defines the natural groupings. The more characters that are used the more complete will be our picture of each group and the less likely are errors to occur. This is not to suggest that all characters should be treated as of equal importance; some are clearly subject to greater variability than others. The important thing is to recognize that each character has some value, and that its value will differ in different groups.

2. Groups having several characters in common are more likely to be closely related than groups with fewer characters in common.

This principle has been severely criticized by Jordan (I898) in a very important paper on the antennae of butterflies, on the grounds that: 'that evidence is taken as the more weighty, i.e. as qualitatively the better, which is numerically, i.e. quantitatively, the higher'. He goes on to say: 'A satisfactory insight into the true connection between the members of any group of animals will not be gained unless the classifier takes as his aim to ascertain, so far as that is possible from the necessarily incomplete knowledge of the organs, the probable phyletic development of each single distinguishing character, so that we get a picture of the gradual modification of the various organs from the ancestral stage of development into those stages 
of mutation which we now observe in the different members of the group to be classified'. This ideal approach led Jordan, on the basis of the antennae, to propose most convincingly a diphyletic arrangement of the butterflies, one branch giving rise to the Papilionidae and Nymphalidae (sensu lato) and the other to the Lycaenidae, Riodinidae and Pieridae, with the Hesperiidae associated in an indeterminate way with the Lycaenid branch. However, few, if any, entomologists would accept this arrangement to-day.

A major difficulty in working out a phylogeny is uncertainty as to what was the primitive state of any particular character, and the question may be further complicated by ignorance as to what specializations may have been acquired in the past and then secondarily lost. Moreover it is clear that it is quite usual for butterflies which possess some undoubtedly primitive characters to possess also some undoubtedly advanced characters (see p. 4II concerning Liphyra). Further, the ideal phyletic method cannot take proper account of convergence, due presumably to common ecological factors, and still less of haphazard coincidence, which I suspect may be of quite frequent occurrence in nature. I conclude that any attempt to work out a phylogeny on the basis of many characters considered individually would inevitably result in several conflicting solutions, so that in the end one would be forced to adopt a compromise unlikely to be any sounder than a quantitative solution in which intuition had also played a part.

\section{As far as possible uniform criteria should be used.}

This principle needs no justification, but in practice is so beset by difficulties that it merits some discussion. Numerous examples could be quoted of a character which shows constancy in one group and variability in another group of apparently equal taxonomic value. A single example will suffice. Within Theclinae the group of tribes which includes the African and Oriental Deudorigini, the predominantly Neotropical and Holarctic Eumaeini (better known as Strymonini) and the Palaearctic Tomarini occurs in every region in a bewildering variety of external form. It seems that the origin of this group of tribes must be ancient, yet the male genitalia are extraordinarily similar throughout the complex (Riley, I956, refers to them as 'greyhound-shaped'). Judged by this one character alone they might all be lumped into very few genera. In addition, venation shows unusual constancy within each tribe. On the other hand the African and Oriental tribes Iolaini and Cheritrini have a more restricted distribution suggestive of a later origin, yet exhibit very great diversity of pattern in male genitalia and venation even in externally similar forms. Marked variation in both features may extend to the subspecific level in Iolaini, whilst in Drupadia (Cheritrini) the number of fore wing veins varies individually. Clearly extreme variability in male genitalia and venation is as much a character of Iolaini and Cheritrini as extreme constancy in these features is a character of the Deudorigini group of tribes. Possibly Iolaini and Cheritrini are undergoing, or have recently undergone, explosive evolution, though in the case of the latter tribe, which includes a number of very small genera, an alternative explanation, suggested to me by Cowan, is that they are relicts of a once much larger assemblage. 
Despite the difficulties referred to above, I think Stempffer paid insufficient attention to the principle of uniform criteria. For example, he accepts a subdivision of what I regard as the tribe Polyommatini into numerous subfamilies on the grounds of differences in the male genitalia which, to me at least, seem trivial but he does not accord similar treatment to Theclinae in which equally great differences occur. Still stranger is his inconsistency in using the partial asymmetry of the male genitalia (confined to the uncus) in Mimacraea and Mimeresia apparently as the main justification for erecting a distinct subfamily to contain these two genera, although he does not subdivide the tribe Pentilini on the basis of the complete asymmetry which occurs in some genera. Asymmetry is a specialized condition which I think is of limited importance at the higher levels of classification, and I think Stempffer was correct in treating complete asymmetry in Pentilini as of no more than generic significance. It follows that I attach still less importance to partial asymmetry, which seems to be fairly widespread among the butterflies; I have noted well-marked examples in Lycaenidae occurring in the brachia in Horagini, in the juxta in the 'Holochila' margarita Semper species-group (Candaladini) and in the valvae in the Philiris diana Waterhouse \& Lyell species-group (Luciini).

4. It is unwise to accord absolute primacy to any one character.

Stempffer (1967:278), who uses the male genitalia as his primary character, writes: 'I believe it is essential, in order to achieve a coherent system, to establish a kind of hierarchy-arbitrary perhaps-amongst characters, and to follow this throughout a family, only using characters of secondary importance in a supplementary sense'. Yet one does not need to look beyond the pages of Stempffer's own work to see what well-marked differences in the male genitalia may result from the geographic separation of closely related genera. For example the Oriental genus Petrelaea (Text-fig. 78; also Stempffer, I967; fig. I98) and the African genus Pseudonacaduba (Text-fig. 76; also Stempffer, figs I96, I97) are so close on external characters that some authors combine them into a single genus; yet they show considerable differences in the male genitalia, the former having relatively small dorsal structures and large free valvae whilst the latter has heavy dorsal structures and relatively very small valvae which are ventrally conjoined to their mid-point. The one decisive similarity which proclaims their relationship lies in an unusual feature in the penis, namely that the ductus enters on the ventral side (it should be noted that Stempffer's fig. I98, like some of his other figures, shows the penis upside down). Equally striking differences are shown in the related genera Neozephyrus and Austrozephyrus (see Howarth, I956), the former having the uncus reduced to two well-separated lobes and the brachia prominent, the latter having a strongly developed, spiked uncus combined with complete absence of the brachia. On grounds of male genitalia alone they might go into separate tribes and one must turn to their external characters, which establish beyond reasonable doubt their common ancestry.

5. The possibility that similarities may be due to convergence or coincidence must always be considered. 
There is a limit to the number of distinct patterns which can be adopted by any organ. Similarities are, therefore, bound to occur from time to time. These may be pure coincidences, or examples of convergence due to some common external factor, or genuine indications of common ancestry. The more uncommon or abnormal such similarities are, the more likely they are to be due to common ancestry. For example, it seems necessary to associate together in the small Thecline tribe Amblypodiini the rather dissimilar-looking genera Iraota (Oriental) and Myrina (African) because of an uncommon feature of venation (veins 5 and 6 arising together from the apex of the fore wing cell), as well as a dominant tail at vein $\mathrm{Ib}$ and a similar development of hair scales on the hind wing, and common larval food plant (Ficus spp.), despite a different type of pupa (girdled in Iraota, attached by cremaster only in Myrina). But even the most uncommon similarities may be coincidental, for example the reduction of vein II of the fore wing to a short cross-vein linking veins Io and I2 in Cyaniriodes (Poritiinae) and in Pistoria and Oraidium (Polyommatinae), or the possession of scent brands on the abdomen associated with hair brushes on the hind wing in such diverse Lycaenid genera as Poritia, Pilodeudorix and Purlisa, as well as in a few Nymphaloid genera. When two or more unusual characters are shared the probability of coincidence is decreased, and one may be faced with many perplexing problems. For example the genera Catapaecilma and Hypochrysops (Theclinae) share an uncommon form of antenna in which the nudum is divided into regular, rectangular segmental blocks by bands of scales commencing half-way down the club and continuing down the shaft (pointed out for Hypochrysops, but missed for Catapaecilma, by Forbes, I957); they also have in common metallic silvery markings on the under surface of all wings (a very unusual feature except in Aphnaeini) with the usual Lycaenine pattern somewhat modified. In other characters the two genera are very dissimilar, for example in eyes, palpi, male fore tarsus, the possession of three hind wing tails and curious secondary sexual characters in Catapaecilma and taillessness and absence of secondary sexual characters in Hypochrysops. Moreover the male genitalia of both, though falling broadly within the Thecline pattern, do not suggest close relationship. Because of so many differences it is not possible to attribute to them a close phylogenetic origin. A still more perplexing problem is presented by the African genus Uranothauma and the Papuan genus Callictita (both Polyommatinae). Several species of the former genus, including $U$. nubifer (Trimen), agree with Callictita in their external characters, notably in possessing secondary sexual characters quite unlike those found in any other Lycaenid genus except Drina (Theclinae), comprising a dense raised patch of specialized hair and short plume scales on the fore wing disc. In addition eyes, antennae, palpi, legs, venation, pattern and wing shape, including a small tornal lobe on the hind wing (a feature otherwise only found in Polyommatinae in a vestigial state in Cacyreus), are all generally similar. So many resemblances in geographically widely separated genera would appear to be beyond the bounds of coincidence or even of chance convergence. Yet their male genitalia are quite unlike. Those of Callictita (Text-fig. 89) are very attenuated and have two most abnormal features, namely that the brachia arise from the outside of the uncus and tegumen, whilst the penis has a curious, trough-like "foot- 
stalk' (a feature otherwise found in Polyommatinae only in a very reduced form in Zizula and Brephidium, though occurring rarely in different forms in some other Lycaenid subfamilies). The genitalia of $U$. nubifer (Text-fig. 9I), which differ considerably from those of the rest of the genus (Text-fig. Ioo), are stout and compressed but otherwise of fairly normal Polyommatine pattern except for an unusual juxta, which is of the normal furca type but bears two additional, less strongly chitinized processes directed caudad and connected to the inner faces of the valvae by a membrane studded with fine hairs. Such marked genitalic differences seem to rule out the possibility that Callictita and $U$. nubifer should have a close common ancestor. I cannot satisfactorily explain their many similarities, but tentatively suggest that they may be due to convergence under the influence of common factors in the remote past when the ancestors of each may have coexisted in Africa, the descendants of Callictita having since died out there and in all intervening areas. I therefore place Uranothauma and Callictita in separate, though adjacent, sections.

\section{SUMMARY OF THE PROPOSED CLASSIFICATION}

\section{LIPTENINAE Röber}

PENTILINI Aurivillius

Alaena section

Pentila section

Telipna section

LIPTENINI Rober

Durbania section

Mimacraea section

Liptena section

Iridana section

Epitola section

PORITIINAE Doherty

LIPHYRINAE Doherty

Liphyra section

Aslauga section

MILETINAE Corbet

MILETINI Corbet

Miletus section

Megalopalpus section

TARAKINI trib. $\mathbf{n}$.

SPALGINI Toxopeus

Spalgis section

Feniseca section

LAGHNOGNEMINI Clench

GURETINAE Distant

THEGLINAE Swainson

LUCIINI Waterhouse \& Lyell

Lucia section

Hypochrysops section
THECLINI Swainson

Thecla section

Amblopala section

ARHOPALINI Bingham

Arhopala section

Semanga section

Surendra section

OGYRINI Waterhouse \& Lyell

ZESIINI Swinhoe

Zesius section

Jalmenus section

AMBLYPODIINI Doherty

GATAPAEGILMATINI trib. $\mathbf{n}$.

Catapaecilma section

Acupicta section

OXYLIDINI trib. $\mathbf{n}$.

HYPOTHEGLINI trib. $n$.

LOXURINI Swinhoe

Loxura section

Neomyrina section

Drina section

HORAGINI Swinhoe

GHERITRINI Swinhoe

Cherita section

Dapidodigma section

APHNAEINI Distant

Aphnaeus section

Pseudaletis section

IOLAINI Riley

Iolaus section

Britomartis section

Hemiolaus section 
REMELANINI trib. $\mathbf{n}$. HYPOLYGAENINI Swinhoe

DEUDORIGINI Doherty

Deudorix section

Capys section

TOMARINI trib. $\mathbf{n}$.

EUMAEINI Doubleday

Eumaeus section

Trichonis section

LYGAENINAE Leach

Lycaena section

Heliophorus section

POLYOMMATINAE Swainson

LYGAENESTHINI Toxopeus

GANDALIDINI trib. $\mathbf{n}$.

NIPHANDINI trib. $\mathbf{n}$.

POLYOMMATINI Swainson

Cupidopsis section

Una section

Petrelaea section

Nacaduba section

Theclinesthes section

Upolampes section
Danis section

Jamides section

Catochrysops section

Lampides section

Callictita section

Uranothauma section

Phlyaria section

Cacyreus section

Leptotes section

Castalius section

Zintha section

Zizeeria section

Famegana section

Actizera section

Zizula section

Brephidium section

Everes section

Pithecops section

Azanus section

Eicochrysops section

Lycaenopsis section

Glaucopsyche section

Euchrysops section

Polyommatus section

\section{NOTES ON SELECTED CHARACTERS}

The characters which I have selected, other than the male genitalia, are all external ones, since these are the most convenient for making quick identifications. Failure to investigate other internal structures, and in particular the female genitalia, may be a serious omission. Still more serious omissions of the prerequisites of a sound classification, as propounded by Ford (I955: 23I), are failure to examine the data given by the selected characters on a statistical basis, neglect of genetic, cytological and, above all, chemical methods, and failure to use physiological data other than by intuition. Investigations of so comprehensive a nature would involve a lifetime study by more than one specialist and are quite beyond my capacity. However, it is to be hoped that they will be undertaken by others and that their results will confirm the relationships suggested by the few morphological and phenotypical characters which I have selected. In the meantime my proposed classification must obviously be regarded as highly tentative; hence the title of my paper.

I deal below with the selected characters in turn, as far as possible contrasting the subfamilies and other subordinate groups with one another. In this way I hope to spare readers the tedium of having to read through a whole series of subfamily, tribal and section diagnoses in order to extract a morsel of comparative information. It also enables me to shorten the keys by omitting characters that are not essential for identification. I have included many peculiar features which appear to have little or no value in higher classification, since occurring in only a few species, in the interests of presenting a more complete picture of each group. In all cases the groups are those listed on pp. 38I-382. 


\section{Characters of the Abdomen and Male Genitalia}

As there is a regrettable lack of uniformity amongst authors over the nomenclature of the male genitalia, I label one or more examples of each term which I employ for the various components in Text-figs 2-I2I (for abbreviations used see pp. 469-470). I take as the standard pattern of male genitalia one in which all the component parts are present, symmetrical and of average development. Deviations from standard are so frequent that it is difficult to know what classificatory value to put upon them. It is tempting to suppose that marked abnormalities, such as the additional dorsal structures of unknown homology and function which occur in the Brephidium section of Polyommatini (text-fig. I09; also Stempffer, I967: figs 2I8-22I), must be of ancient origin and major taxonomic importance. Such may not be the case. As pointed out to me by Holloway (in litt.), specialization for a particular mode of life tends to produce bizarre morphological characters. Such evolution is usually an 'evolutionary backwater', where ecological restriction and rarity, followed by further specialization, results in continually narrowing the ecological niche of the species until it becomes extinct. From our present knowledge it is impossible to correlate the bizarre dorsal structures of the Brephidium section with a particular niche, but the probably relict distribution of the few extant species, in S. Africa and the Sonoran area of N. America extending to the northern part of the Neotropical Region, suggests that they may be on the road to extinction despite their abundance in their present, limited areas of distribution. As already pointed out, butterflies may undergo quite fundamental changes in the male genitalia more quickly than equivalent changes in pattern or other characters. I therefore doubt whether the male genitalia have the overriding importance in classification which is generally attributed to them; in particular I think it unwise to base major taxonomic divisions on bizarre characters (as in Brephidium) without supporting evidence from other distinctive characters. It is perhaps of significance that Mayr (Ig63 : I03) records that the genitalia of insects are nowadays regarded as of only slight importance as isolating mechanisms.

The genitalia of many species of Lipteninae have been described and figured by Stempffer, sometimes in collaboration with Bennett, in a series of admirable papers. The subfamily shares with Poritiinae a feature not found elsewhere in the family: the saccus (Text-figs 3-I5), when developed, is directed caudad. In Pentilini it is more or less inflexible, but in Liptenini it is flexibly bent back and when the genitalia are withdrawn from the abdomen during dissection it may get retracted so that it ends up pointing in a normal cephalad direction; it must be borne in mind that microscope preparations may, on this account, give a misleading impression of its position in nature. A conventional juxta (Text-fig. 2) does not occur, but a homologous structure is a distinctive feature of Liptenini. This comprises a quite well-sclerotized sheath wrapped round the basal or subbasal part of the penis, from which a pedicel, of variable length, descends to hinge with the apices of the sacculi (Text-fig. 2). The pedicel/sheath complex is not always simple. For example, in Baliochila singularis Stempffer \& Bennett and, to a less striking degree, in Cnodontes and Tetrarhanis (Text-fig. 13 ), the pedicel is continued as two long arms above the point of attachment to the penis. In the typical species of Baliochila (Text-fig. ro) and 
Eresinopsides two rather similar arms, termed 'special processes' by Stempffer, are attached to the top of the sheath and also, by a semi-membranous connection, to the inner face of the tegumen. A much shorter, unpaired dorsal process of the pedicel is borne by Falcuna. Brush organs ${ }^{2}$ occur in a number of genera, almost always in the Epitola and Iridana sections of Liptenini, less commonly in the Liptena section and not at all, so far as known, in the Mimacraea and Durbania sections of Liptenini nor in Pentilini. At any rate I have not found them in the all too few preparations I have made of the last three groups, nor are they reported by Stempffer or Clench. Total absence, if substantiated, would be of importance in confirming the evidence of other characters for the separation of these groups. Their sporadic appearance is parallelled by the equally sporadic appearance of other secondary sexual characters in this and other subfamilies, but this inconstancy does not greatly detract from their significance as taxonomic characters. The brush organs (Pl. 6, figs 35, 36) comprise paired sacs bearing tufts of large scales, usually boat-shaped but sometimes, for example in Aethiopana (Text-fig. I4) Phytala, Powellana, very long and narrow like daffodil leaves, which are attached to the lower end of the vinculum and saccus. The sacs appear to be capable of inflation but otherwise very limited movement, but no doubt the caudal inclination of the saccus enables them to be brought into action when the valvae are opened without the need for further eversion. The scales also appear to be capable of inflation.

The genitalia are remarkably homogeneous in the Epitola and Iridana sections, but exhibit a very wide range of patterns in the Liptena, Mimacraea and Durbania sections of Liptenini. Stempffer (I967:269) suggests that in the latter groups we are confronted with many different lines of descent, some of them very ancient, which have undergone a complete modification of their original external appearance and by convergent evolution have acquired similarities of pattern and development. As the component genera have presumably co-existed and been acted upon by the same external factors for a very long time, and also as some of the genera are mimetic, convergence may well be the correct explanation. However I do not find it entirely satisfying, and an alternative explanation, admittedly no more convincing and inconsistent with the view that the genitalia are not important as isolating mechanisms, is that the differences are due to divergent evolution of the genitalia favouring the prevention of interbreeding between externally similar forms. This does not imply a literal acceptance of the old and discredited 'lock and key' theory; but I do think that when the genitalia of related species differ widely they must have considerable influence as isolating mechanisms. Moreover it seems possible that there may be a correlation between, on the one hand, the homogeneous genitalia of the Epitola and Iridana sections and the almost invariable presence of another, and perhaps more effective, isolating mechanism in the form of brush organs, possibly diffusing specific scents and, on the other hand, the heterogeneous genitalia and absence of brush organs in the other three sections.

${ }^{2}$ The term brush organ was apparently first used by Pierce (Varley, 1962). Both Clench and Stempffer use the term coremata. I prefer the former, as I believe that coremata should be used only for the 'eversible sleeve-like bags sometimes of great length and covered with hairs' (Janse, 1932) which certain moths can extrude from a variety of positions within the abdomen. 
The genitalia of Pentilini differ from those of Liptenini, and indeed from all other Lycaenidae, in having the vinculum interrupted and hinged at the tergal-sternal suture. I divide the tribe into three sections on the basis of further differences in the genitalia. In the Alaena section (Text-fig. 7) the genitalia are symmetrical, with normal brachia and with valvae which are fused, not hinged, to the lower part of the vinculum and are dorsally conjoined by a broad transtilla passing above the penis. In the Pentila section (Text-fig. 6) the brachia are aborted, the valvae are fused to the vinculum and the whole armature is asymmetrical. A further peculiarity is that the penis appears to have a part of the vesica permanently everted into a long, recurved flail (Stempffer, I967, says that it was everted in all the specimens he had examined and my more limited experience has been similar), but the basal portion of the vesica, bearing a large cornutus, is found normally retracted within the penis. The Telipna section, comprising Telipna (Text-fig. 8) with symmetrical genitalia and Ornipholidotos (Text-fig. 9) with asymmetrical genitalia, differs from the two preceding sections in two respects. Firstly, what I take to be the valvae, but termed special processes by Stempffer, are hinged by a membrane to both upper and lower parts of the vinculum. Secondly, the saccus, which may be partially divided, is distally fused with the eighth sternite, which in turn is more strongly sclerotized than usual. The complex formed by the lower part of the vinculum, saccus and sternite is capable of up and down movement and presumably plays some part in clasping the female during copulation. Stempffer (I967: I0, 23) regarded this complex as the valvae, but I cannot agree with his interpretation; compare his figs 4 and 14 with my Text-figs 8 and 9 .

The genitalia of Poritiinae show the affinity of this subfamily to Lipteninae in two respects. Firstly, the saccus, which is quite strongly developed in Deramas (Text-fig. 4) and Zarona, less so in Simiskina and Cyaniriodes (Text-fig. 5) is directed caudad. Secondly, the penis of Cyaniriodes is surrounded by a sheath borne on a pedicel, exactly as in Liptenini. In Deramas and Zarona there is also a pedicel which descends between, but is not hinged to, the sacculi; the latter have strong scimitarshaped sclerites hinged to their apices which loosely embrace the ventral part of the penis, but they are not united to the pedicel nor to each other and so cannot be regarded as a juxta in the strict sense, although the whole arrangement is more or less homologous with a juxta. The remaining genera of Poritiinae (Poriskina not examined) possess neither pedicel nor sclerites, but the inner edges of the sacculi are thickened longitudinally, as though to act as a guide and support for the penis. A feature of the subfamily, first pointed out by Clench (I955), is the possession by both sexes of sparse tufts of bristles of unknown function on the ventral surface of a variable number of the abdominal segments. This feature appears not to occur in any other Lycaenid subfamily, but occurs rarely in Riodinidae, for example in Laxita. The genus Poritia bears scent brands on the sides of the male abdomen used in conjunction with hair tufts on the hind wing, a feature otherwise found in Lycaenidae only in the Thecline genera Pilodeudorix and Purlisa.

Liphyrinae have genitalia of a common-place pattern, including a true juxta. Absence of brachia helps to separate the Aslanga section (Text-fig. I7) from the Liphyra section (Text-fig. I6), but atrophy of the brachia is of such frequent 
occurrence in so many diverse groups that it can only be regarded as a character of very minor significance.

A probably significant feature of Miletinae is that the valvae are dorsally conjoined, or nearly so, by a membrane or some form of transtilla-like structure above the penis, a feature found also in Aphnaeini (Theclinæ). The union takes a number of different forms. In Spalgis (Text-fig. 22) union is by a weakly sclerotized membrane near the distal extremities of the valvae. In Taraka (Text-figs 24, 25), the only genus to lack brachia, union is by a more strongly sclerotized dorsal membrane and in addition the valvae are ventrally conjoined throughout most of their length. In Feniseca (Text-fig. 23) union is by a typical transtilla joining the proximo-dorsal extremities of the valvae. In Lachnocnema (Text-fig. 2I) partial union occurs through two dorsal processes of the valvae, which have been termed labiles, shaped like bent arms, which are fused to the diaphragma along the inner edge of the upper arm, the lower arm being free and directed caudad. In Thestor (Text-fig. 20) there are two labiles which are contiguous on their inner edges but are joined to the valvae only by a membrane. In Miletini (Text-figs I8, I9) union is by a rather weakly sclerotized transtilla which is drawn forward to give a narrow bridge cephalad of the vinculum. The tribe also possesses a curious and unique feature named 'listron' by Fruhstorfer (IgI6). This comprises a pair of long apophyses arising from the proximal edge of the eighth tergite and directed cephalad, which recall female ovipositor lobes and sheathe the characteristic enormous, flattened uncus lobes. In addition the eighth sternite bears a pair of hair brushes. In general the genitalia of Miletinae are so diverse that it seems necessary on this account, as well as because of other external characters, to split them into a number of tribes and sections disproportionately large in relation to their small number of species.

The genitalia of Curetinae (Text-fig. 26), with a large hood-like uncus and valvae dorsally united by a central plate above the penis, show affinity with Riodinidae, as Shirôzu \& Yamamoto (I957) have pointed out, and in particular with the tribe Abisarini.

The genitalia of the related subfamilies Theclinae, Lycaeninae and Polyommatinae tend to be rather similar. However the majority of Theclinae can be separated from the other two subfamilies by a combination of three characters: comparatively heavy dorsal structures, a penis widely open on the dorsal surface for the reception of the ductus and with the zone more or less central and, lastly, comparatively strong sclerotization of the subscaphium. The last feature, which for greater clarity has been omitted from all Text-figs other than Text-fig. 2, reaches its greatest development in Surendra where, as pointed out by Riley (I956), the subscaphium comprises a plate fused to and uniting the bases of the brachia. However the Thecline genitalia show a wide range of variation, and none of the above three characters are constant so that it seems impossible to find a reliable means of separating with certainty all Theclinae from the other subfamilies. Particularly puzzling is the very occasional occurrence of an atypical penis in which the ductus enters cephalad, as in Chaetoprocta (Text-fig. 3I) (Theclini) or the Tajuria mantra (Felder) species group (Iolaini), both of which belong to large tribes which otherwise have a normal Thecline penis. The most specialized genitalia are found in Cheritrini, Oxylidini and Britomartis 
(Iolaini). In Cheritrini the uncus and tegumen are sometimes fused and indistinguishable, with the consequent disappearance of the semi-membranous lateral window which is normally present in all Thecline genera, and the brachia are absent-a rather uncommon feature in Theclinae. In the Oriental Cheritra section the extreme of abnormality is shown by Drupadia and Cowania gen. n. (p. 450) (Text-fig. 42) in which the uncus-tegumen complex comprises large, widelyseparated, triangular plates with their bases extending as far as the junction of vinculum and saccus. The African genus Dapidodigma (Text-fig. 53), forming a distinct section of Cheritrini, has a large hood-like structure above the penis, regarded as the fultura superior by Stempffer (I967: I2I, figs I08, I09) who describes in detail and figures the genitalia. Oxylidini are peculiar in that the normal function, and to some extent position, of valvae and juxta appear to be reversed. The valvae are small, rather rigidly fixed to the vinculum, directed upwards and seem to act as a furca-like support to the penis, whilst the juxta, most highly developed in Syrmoptera (Text-fig. 46), is directed caudad, is capable of up and down movement and appears to be designed for clasping the female during copulation. In Britomartis (Text-fig. 59), as pointed out by Riley (I956), there are curious chitinous structures of unknown function lying within the eighth sternite, which is itself strongly sclerotized and bifid, whilst the genitalia, which are smaller than usual, lie wholly within the eighth tergite. All the component parts are present but the valvae are fused, not hinged, to the vinculum, recalling a similar feature in Pentilini. If overriding importance were to be attached to the male genitalia, it would probably be necessary to place Britomartis in a subfamily by itself. However, apart from Hypolycaena-like antennae, its external characters accord well with those of Iolaini, of which it undoubtedly forms a component.

When dealing with the Holarctic Theclinae Riley (I956) was able to divide the genera into two basic genitalia types: the 'greyhound' type in which the vinculum is inclined, giving a streamline effect, the valvae are small and often ventrally conjoined, the penis is usually long and thin and the juxta is absent; and the 'bulldog' type in which the vinculum is more upright and a juxta is present. The greyhound type is constant in Deudorigini (Text-fig. 65), Tomarini (Text-fig. 64) and Eumaeini (Text-figs 66, 68), whilst the bulldog type is characteristic of Theclini (Text-figs 29-32), Arhopalini (Text-figs 33, 39, 40), Iolaini (Text-figs 55-57) and a number of other tribes. Unfortunately, however, a clear-cut distinction between the two types cannot be maintained on a world-wide basis. The first approach from the greyhound to the bulldog type is made by Hypolycaenini (Text-fig. 60), in which the valvae are rather Deudorigine-like and the juxta is absent, but in which the vinculum is usually comparatively broader and more upright. A few small genera link Hypolycaenini to Iolaini both in their external characters and male genitalia. One of these is Remelana (Text-fig. 6I), which has a small U-shaped juxta but is otherwise of the greyhound type; its penis is furnished with an unusual cornutus resembling two long saw blades similar to the cornutus found in a few African Hypolycaena species. In Remelana loss of juxta by atrophy seems to be indicated. Another link genus is Hemiolaus (Text-fig. 58) which has the male fore tarsus and antennae of Hypolycaenini, but the eyes and secondary sexual characters of Iolaini. 
The particular interest of its genitalia is that they appear to indicate a completely different way in which the juxta may be lost. Its juxta comprises a long, shallow, trough-like plate, briefly incised at its distal end, which, instead of being upright and giving support to the penis as in typical Iolaini, lies parallel to the valvae, which are unusually widely separated at their bases, and is joined to them almost throughout its whole length by a membranous connection near their ventral edges. It would seem that the juxta is evolving towards complete fusion with, and ultimate absorption into, the valvae. The fact that the headquarters of Hemiolaus is in Madagascar (four out of five species) suggests that it is a relict genus which, with Remelana and related genera, may represent the remnants of a bridge now reduced to isolated stepping stones, by which Iolaini and Hypolycaenini were once more broadly united.

Internal shelf-like ridges or linear thickenings of the genitalia occur in several tribes. A longitudinal ridge running across the lateral process of the tegumen to the point of attachment of the brachium is a good diagnostic character of Hypolycaenini (Text-fig. 6o) and also of the Arhopala (Text-fig. 33) and Semanga (Textfig. 40) sections of Arhopalini. More or less similar thickenings or ridges occur in Ancema and Pseudotajuria (Remelanini) (Text-figs 62, 63) and in some species of Eumaeini. More often in Eumaeini any ridge or thickening which may be present is obliquely slanted, and the same applies to Iolaini, in which internal thickenings occur less frequently. Remelana (Text-fig. 6I) is unique in possessing a very wide dentate and corrugated ridge along the distal margin of the lateral process of the tegumen. In other tribes internal ridges do not seem to occur.

As already mentioned, brush organs occur in many Neotropical Eumaeini. A brush organ also occurs in an Oriental species of Iolaini, Myrina jalindra Horsfield, which recent authors have misplaced in Charana; the species requires a new genus, which will be named and described in a later publication. Those brush organs which I have examined fall broadly into three types; there may well be others. The commonest type comprises paired tufts of long specialized scales arising from sacs mounted on the mid-proximal edge of the vinculum, which is usually somewhat shouldered for the purpose but in Thereus (Text-fig. 68) is drawn out into a long arm directed proximad, and apparently incapable of much further extrusion. As well as in Thereus this type occurs in Theritas, Arcas, Psendolycaena, Evenus, Molus, Atlides, Macusia, Mithras, Rekoa, Paiwarria, Lamprospilus, Heterosmaitia and a considerable number of unclassified 'Theclas'. A variant of this type occurs in Chalybs, in which the tufts are situated at the base of the vinculum and are directed distad; it shows an approach to the second type, confined to the curious little genus Ipidecla, in which the tufts are mounted on sacs below the bases of the valvae. The third type comprises compact hair-pencils mounted on an invagination of the internal integument of the abdomen; in Eumaeus and Theorema these pencils are almost as long as the abdomen and appear to be capable of full eversion; in Brangas the pencils are much shorter and appear to be capable of only partial eversion, so that to a certain extent this genus links the Thereus group with Eumaeus. Further study may show that it is possible to subdivide the Eumaeini according to the presence and type of brush-organ. Another curious feature is the presence of 
a deep pit on the ventral surface of the abdomen in Eumaeus, and also in a much less marked form in Evenus. The scales lining the pit are rather narrow, but do not give the impression of being scent scales, and I do not know what purpose the pit serves.

In a few species of Theclinae the end of the female abdomen bears a tuft of specialized scales; a well-known example is the European species Nordmannia acaciae (Fabricius). In Chaetoprocta (Theclini) and Pseudaletis (Aphnaeini) the tufts are particularly large. In the former the specialized scales are long and very deeply incised, resembling a two-pronged fork, and adhere to the eggs, which are laid in a single mass (like some moths, for example the Gypsy Moth, Lymantria dispar (L.)); they presumably serve as an effective 'chevaux-de-frise' against predators. In Pseudaletis the scales are shaped like small spoons with very long handles, somewhat resembling the scales of Nordmannia acaciae. Probably they serve the same purpose as in Chaetoprocta, but as far as I know their function has never been studied, and it seems possible they may diffuse scent either to attract males or to repel predators. It is not possible to use such an uncommon character in higher classification, and its occurrence in widely separated genera must be due to convergence, or even to coincidence.

The Lycaeninae (Text-fig. 69) have male genitalia characterized by long digitate uncus lobes and long brachia, and show great uniformity throughout the small subfamily. Saccus and juxta are always well developed, and the long to moderately long penis is widely open on the dorsal surface for the reception of the ductus with supra- and subzonal portions subequal, as in many Theclinae.

The male genitalia of Polyommatinae, with the exception of the Brephidium section of Polyommatini (Text-fig. Iog) already mentioned on p. 383, are more homogeneous than those of Theclinae. Nevertheless they are of importance in defining the sections of the enormous tribe Polyommatini, since some external characters such as pilosity of the eyes or type of scaling on the palpi, which are often of diagnostic assistance in other groups, are so variable, even infra-generically, as to be of very little use in classification, whilst other characters, such as the position and number of hind wing tails, are equally valueless because of their constancy. I discuss below each component of the male genitalia, drawing attention to any feature which has classificatory value.

(a) Vinculum. Its shape, especially when viewed laterally, may provide useful characters. A pronounced subtriangular extension cephalad, as in Rhinelephas (Text-fig. II 7 ), serves to define the large, predominantly Oriental Lycaenopsis section, even though more or less similar extensions crop up occasionally in other sections, for example in some 'Castalius' species (Text-fig. I04). The absence or very weak development of a saccus is a character of Niphandini (Text-fig. 7I) and of all the sections of Polyommatini other than the small Una (Text-fig. 75) and Petrelaea (Text-figs 76,78 ) sections, whilst its constant presence in Lycaenesthini (Text-fig. 70) is an important character of this tribe.

(b) Tegumen. Is usually rather weakly developed and seldom gives good characters at the section level.

(c) Uncus. The type of uncus has been used in the past to define so-called 
'subfamilies', down-graded by me to sections of Polyommatini. Its shape is variable, ranging from a long, tapered spike in Talicada (Text-fig. II6) through Everes and other closely related genera, in which the shorter uncus is at most only a little incised, into Azanus (Text-fig. II4) in which it is narrowly divided into separate lobes, and on through genera showing a gradually increasing gap between the lobes. I do not regard the uncus as of fundamental importance, but its shape certainly helps to define some sections, notably the Everes and Azanus sections.

(d) Brachia. These are usually simple curved hooks. But in the Leptotes section (Text-fig. I05) they are often more or less dentate or serrate, whilst a good character of Candalidini (Text-figs 72, 73) is that they always bear a branch, usually vestigial, near their apices. Absence or partial atrophy of the brachia occurs sporadically, for example in Erysichton (Nacaduba section), but constant absence is a good character of the Upolampes section (Text-figs 80-88) whilst absence in all but a few of the Lycaenopsis section is also significant.

(e) Valvae. These can seldom be relied upon for good characters, though in a few sections, notably Polyommatus and Euchrysops, they show unusual constancy. On the other hand in some genera, for example Nacaduba, inter-specific differences may be enormous.

(f) Penis. This organ appears to be more important in the classification of the subfamily than any other component of the genitalia. The most useful characters are the point of entry of the ductus, the presence or absence of a coecum and the position of the zone. In Lycaenesthini, Candalidini and Niphandini the penis is widely open on the dorsal surface and the sub- and suprazonal portions are subequal, as in nearly all Theclinae. In Polyommatini the ductus may enter dorsad, with or without a coecum, or cephalad or even on the ventral surface. In most sections the suprazonal portion is very short, but it is more nearly equal in several sections, including the Polyommatus (Text-figs I20, I2I), Euchrysops (Text-fig. II9) and in some members of the Castalius (Text-fig. I04) sections. These three all have the ductus entering cephalad and also usually have alulae at the zone, and thus may be more closely related to one another than to any other section. Frequently the penis ends in a single or double Chapman's process. The most curious penis, bifid and resembling a bird's beak, occurs in the Brephidium (Text-fig. Iog) and Zizula (Text-fig. IIo) sections, suggesting that they must be closely related despite the presence of abnormal and additional dorsal structures in the former which are absent in the latter. The presence of cornuti or their type do not appear to be of significance; for example, in the Upolampes section cornuti range from complete absence through an increasingly complicated series to an astonishing assemblage of every size and shape in Pistoria (Text-fig. 86). As the fascinating little Upolampes section is remarkable for unusual features in genitalia and venation, I have figured the genitalia of all the described component species (Text-figs 8o-88).

(g) Juxta. The presence of a juxta is a constant feature of the family. Usually it is U-, V-or Y-shaped, and has been aptly named the furca, but this shape is not confined to the subfamily. The juxta shows considerable variation in size, especially in Candalidini, where it reaches its maximum in Nesolycaena (Text-fig. 73), whilst in a few species of 'Holochila' it is highly asymmetrical. When not shaped 
like a furca, as in the Una section (Text-fig. 75), or when modified, as in most of the Castalius section, its shape may be of diagnostic importance. It is sometimes difficult to determine whether sclerotizations below the penis should be regarded as part of the juxta or mere sclerotizations of the anellus; occasionally both, with the valvae, form a confusing complex, as in some species of the Upolampes section.

(h) Abnormal features. The curious dorsal structures of the Brephidium section have already been referred to; for further details see Stempffer (I967). Cacyreus (Text-fig. I02) has a quite prominent scaphium which, viewed dorsally, appears as a comparatively weakly sclerotized and more or less triangular process between and below the uncus lobes. An apparently unique feature occurs in Psychonotis (Text-fig. 93); the diaphragma incorporates in its upper half a quite strongly sclerotized semi-circular band which is membranously connected to the lateral processes of the tegumen and forms with the juxta an almost continuous ring loosely surrounding the penis. This band does not appear to be homologous with the sclerotization of the subscaphium which, though often well-developed in other subfamilies, is always absent or very weak in Polyommatinae. The Polyommatus section (Text-figs I20, I2I) almost always has a suspensorium consisting of two moderately sclerotized, rod-like processes descending from the inner face of the tegumen and appearing to act as a guide to the penis, which pierces the diaphragma unusually high up. In the Sonoran and Neotropical species of this section a further peculiarity is the frequent presence of a sagum (Nabokov, I945) comprising paired or conjoined sclerites, sometimes very large and dentate, which loosely sheathe the penis. The Zizula and Zizeeria sections appear to be related because of the possession by Zizula (Text-fig. I09) and Zizina (Text-fig. I06) of long spine- or rod-like processes of the valvae. Other unusual features, such as embellishment of the valvae or uncus lobes by bristles or tufts of long hairs occur sporadically and appear to be of little value in classification.

\section{Characters of the Head}

(a) Antennae. At the family level the antenna, and in particular the presence and arrangement of grooves and carinae, is of primary importance, as shown by Jordan (I898). But in the ungrooved and unridged antenna of Lycaenidae it is difficult to find precise, easily examined characters of use in classification. I have not attempted an examination of the sensory hairs clothing the nudum (unscaled portion) nor of the bristly sensillae borne on most of the segments, since preliminary investigation under low power showed no promise of results likely to be of use in a key. Riley (I956) used the absence of white annulations outlining the shaft (flagellum) segments as a tribal and generic character in the Holarctic Theclinae, but I have not found it to be of significance; in some genera, for example Arhopala, the annulations vary interspecifically from absence to prominence. It appears to be the rule for the total number of segments to vary individually, especially in Miletini, for example Allotinus horsfieldi (Moore) varying from $5 \mathrm{I}$ to 62 segments and Allotinus unicolor Felder varying from 43 to 53 segments in a dozen Malayan examples of each chosen at random. I have not found any convincing evidence of sexual differences in the number of segments, even in Niphanda, a genus exhibiting the most 
marked dimorphism in the shape of the club and extent of the nudum. Clench (I955) made use of a comparison of the length of the longest shaft segment over the length of an average club segment, but it seems to me that the relative length and breadth of the central shaft segments and also the total number of segments more often give helpful, if imprecise, information as to relationships.

In Lipteninae the antennae are variable and of little use for classification even at the generic level. A flattened and abrupt club, sometimes with a dentate profile, to which the nudum is confined is usual in Pentilini and in the Durbania, Mimacraea and Liptena sections of Liptenini, and the same type occurs rarely in the Epitola section (for example in Epitolina) alongside antennae with cylindrical clubs and nuda extending down the shaft.

In Poritiinae the form of antenna is constant, with a cylindrical club and nudum extending in a taper down the shaft. The same applies to Liphyrinae and Miletinae, except that the curious little species Taraka mahanetra Doherty has the nudum confined to a rather abrupt club. Curetinae also have a cylindrical club and tapered nudum, but possess an unique structure of unknown function in the form of a fringe of about a dozen bristles, about as long as the shaft is wide, borne on the ventral surface of the basal three or four shaft segments.

The possession of a cylindrical club has often been used in keys as a character to separate Theclinae from Lycaeninae and Polyommatinae, but there are a number of exceptions in Eumaeini and Hypolycaenini. The abruptness of the club may vary greatly within the tribes of Theclinae, but the club is always gradually incrassate in Arhopalini, Amblypodiini and Zesiini. The nudum is more or less tapered and commonly extends down the shaft in an unbroken taper or in a series of detached patches of decreasing size, and is often more extensive in the female than in the male. Its rather constant extent is a character of some tribes, but in others, for example Aphnaeini and Eumaeini, its extent is extremely variable. The number and length of the segments is also a fairly good character of some tribes, for example in Arhopalini their number always exceeds forty and about the middle of the shaft their length at most barely exceeds their width, whereas in Hypolycaenini their number is always below forty and the shaft segments are at least three times as long as wide. However some tribes, and the subfamily as a whole, exhibit a wide range in the number of segments. The smallest count I have made is 23 in several species of Eumaeini the largest 65 in Arhopala hercules (Hewitson); no doubt a larger count would extend these figures in both directions.

In Lycaeninae the club is more or less flattened and the nudum is confined thereto. The segments usually number between 30 and 35, and on the shaft are rather long and narrow, as in Hypolycaenini.

In Polyommatinae the tribe Niphandini is well characterized by the exceptional degree of sexual dimorphism; in the male the club is moderately abrupt and usually somewhat flattened beneath, and the nudum is confined to it; in the female the club is long, gradually incrassate and cylindrical (except that there is a small area of flattening near the apex in Niphanda fusca (Bremer \& Grey)) and the nudum extends down the shaft almost to its base in an unbroken taper. The antennae also provide a fundamental character in Candalidini; the nudum is crossed by segmental 
bands of scales which commence near the tip of the club and extend a varying distance down the shaft. The same type of banding also occurs in the Thecline tribes Luciini and Catapaecilmatini, though in these the banding commences about half-way down the club; this similarity appears to be due to convergence. In Lycaenesthini and Polyommatini the nudum ends abruptly and is always confined to the club, which is more or less flattened or hollowed beneath. In some species of the former tribe the degree of flattening may be very slight in life, but the hollow club is liable to collapse after death in such a way that the line of flattening divides the nudum into two nearly equal parts, whereas in the latter tribe the nudum is almost wholly contained within the flattened or hollowed portion of the club. In Polyommatinae the number of segments is nearly always under forty and the shaft segments are long and narrow, at least three times as long as wide even in genera with an exceptionally high number of segments such as Danis with about 54 segments or Niphanda with about 44-49 segments.

(b) Eyes. Smooth eyes are a character of Lipteninae, Poritiinae (except some Deramas species), Liphyrinae, Miletinae (except Lachnocnema) and Lycaeninae. Hairy eyes are a character of Curetinae and the Thecline tribes Deudorigini, Tomarini, Hypolycaenini and Eumaeini (though very inconspicuously haired in a few Neotropical genera) and also of the majority of Theclini. In the remaining Thecline tribes smooth eyes are the rule with but few exceptions. In Polyommatinae smooth or hairy eyes are of little help in classification even at the generic level.

(c) Palpi. I have found these of but slight use in classification; moreover sexual differences are often considerable, which restricts still further their convenience as diagnostic characters. Reuter (I896) drew attention to a specialized area in the butterflies on the inner face of the basal joint, which he termed the 'basalfleck'. This area, which occurs in both sexes, is devoid of scales, corrugated and bears minute cones ('kegel'). Its function is unknown and does not appear to have been investigated histologically. Its extent is variable; in Lipteninae and Poritiinae it extends at least the full length of the basal joint and may be continued on the second joint. In Polyommatinae, Lycaeninae and some tribes of Theclinae the cones are concentrated into a single or partially double bi-coloured patch. The cones are extremely small compared with those of other families and any worthwhile examination would have to be carried out under a very high magnification; I have not attempted one. Reuter erected the tribe Miletidi on the basis of the presence of very fine hairs on the basal-fleck in Miletus and Allotinus. These hairs also occur in the African section of Miletini, and appear to be a good tribal character since they do not occur in the other tribes of Miletinae nor in the comparatively closely related Liphyrinae.

The relative length of the joints is occasionally of assistance at tribal or lower level. In the vast majority of genera in males the third joint is shorter than half the second joint, but a third joint at least half as long as the second joint is a constant character of Hypolycaenini and Remelanini. The scaling of the second joint may sometimes be useful, appressed flat or slightly bristly scales being characteristic of Lipteninae (with a few exceptions), Poritiinae, Liphyrinae, Miletinae (except Lachnocnema) Curetinae and several Thecline tribes. Hairy palpi are constant in 
Lycaeninae, whilst in Polyommatinae the scaling, like the pilosity of the eyes, is so variable as to be almost useless for classification. Very small palpi occur in the Liphyra section of Liphyrinae, possibly having some connection with the complete atrophy of the proboscis, but very small palpi also occur in Pentilini, in Pseudaletis (Theclinae: Aphnaeini) and in a few Neotropical Eumaeini in all of which a proboscis of normal dimensions is present. Slender, asymmetrical palpi are constant in Miletini, and in Tarakini occur in Taraka mahanetra Doherty and to a lesser and variable extent in T. hamada (H. Druce).

(d) Proboscis. So far as I am aware the proboscis has not hitherto been used in Lycaenid taxonomy. However it is quite useful at the subfamily level, the important diagnostic feature being the development of sensory hairs on the outer surface and sides of the shaft. The development of the terminal sensory area bearing papillae (? taste-buds) may be of some subsidiary value, but is not a convenient character to use in set specimens as relaxing is usually necessary, and I have not tried to investigate it fully. In Lipteninae (except the Durbania section in which the proboscis is very short and apparently undergoing atrophy) and Poritiinae the shaft bears few, irregularly spaced, fine hairs and in the latter subfamily the terminal papillae are quite prominent. In Liphyrinae and Miletinae there is a regular arrangement of quite closely spaced hairs, except in those genera in which the proboscis is completely absent (Liphyra, Euliphyra, 'Aslauga' pandora H. H. Druce) or very small and apparently undergoing atrophy (some Aslauga species, Taraka). In Curetinae both sensory hairs and terminal papillae are particularly strongly developed. Theclinae, Lycaeninae and Polyommatinae have a smooth proboscis, except that short sensory hairs are quite well developed on the inner surface of the shaft in a number of Neotropical Eumaeini and also in Callictita (Polyommatinae). Terminal papillae are often quite well developed in the first two subfamilies, but in Polyommatinae are weakly developed or absent except in the small Una section.

\section{Characters of The Legs}

The most perplexing character of the Lycaenidae is the occurrence of a segmented, clawed and fully functional fore tarsus in males of a number of quite diverse genera, whereas in the great majority of the genera the male fore tarsus is partially aborted and fused to a single clawless segment. In other butterfly families the development of the fore legs is relatively constant in each sex, and these limbs have been widely used as primary diagnostic characters at the family level. It seems certain that a segmented and fully functional fore tarsus in both sexes represents the primitive state in the butterflies, and consequently those Lycaenid genera bearing such tarsi in the male as well as in the female have usually been regarded as the most primitive in the family (for example see Shirôzu \& Yamamoto, I956). I am by no means convinced that this view is invariably correct, although I think it is possibly so in the case of Liphyrinae and the Miletine tribe Lachnocnemini, in which the males of all the included species have a segmented fore tarsus; indeed, I have assumed later (see Table A) that it is so. But within Theclinae a segmented male fore tarsus occurs in the following genera, some of which appear on other grounds to be only weakly separated from genera having an aborted male fore tarsus: Artopoetes, 
Japonica, Ussuriana, Coreana and Protantigius (Theclini), Sukidion and Pratapa (Iolaini), Titea gen. n. (p. 452) (Luciini) and Theclopsis (Eumaeini). Amongst the foregoing genera the most interesting case is that of Pratapa. It does not seem to have been noted previously that the type-species, $P$. deva Moore, has a segmented male fore tarsus, whereas $P$. icetas (Hewitson), a species having close similarity in male genitalia as well as in all external characters (including secondary sexual characters), has the usual aborted fore tarsus, as do the remainder of the species currently included in this 'omnibus' genus. In Iolaini, as already pointed out on p. 378, there is great diversity of pattern of male genitalia above the species-group level, so that the occurrence of a similar pattern in $P$. deva and $P$. icetas, taken in conjunction with their other similarities, would be almost beyond the bounds of coincidence or convergence if the one was a primitive and the other an advanced species. I think, therefore, that it can be taken as virtually certain that the two species are closely related and that the differentiation of fore tarsi occurred recently. Moreover, despite the principle of irreversibility which would normally prohibit the reacquisition of a character once lost, I think it probable that the segmented fore tarsus is a secondary reacquisition from the aborted state. Further indirect evidence that this may also have occurred in the other Thecline genera with a segmented fore tarsus is supplied by the mere fact that these genera are spread between four tribes, of which I consider two to be phylogenetically quite advanced (see Text-fig. I on p. 47I). If the segmented fore tarsus was primitive, it would be necessary to believe that the ancestors of all these tribes had such a fore tarsus and that the aborted state had later evolved independently in each tribe- a by no means impossible hypothesis, but one which I regard as inherently improbable. Since the Lycaenidae invariably have the female fore tarsus unmodified, the aborted male fore tarsus must be a sex-controlled character. Originally I assumed that the males of all species must carry the gene for the segmented 'female' condition and that reacquisition of a segmented tarsus might occur through mutation or through hybridization of stocks having different sex-determinant values in their genetic make-up. But on referring these ideas to Professor Clarke he replied with the much better suggestion (proposed by his wife Mrs C. A. Clarke) that the gene controlling the fully functional fore tarsus might be located on the $\mathrm{Y}$ chromosome, so that it would normally be confined to females; but occasionally there might be crossing over between the $\mathrm{Y}$ and $\mathrm{X}$ chromosomes so that the males would show it, although the expression might be modified by the total gene complex. It seems at least possible that all the genera with a segmented male fore tarsus may have evolved independently in this way, and therefore I cannot regard this character in the Lycaenidae as one of fundamental significance.

Clench (I955) seems to have attached great importance to characters of the legs. I agree with him that the absence of the paired spurs at the lower end of the midand hind-tibiae are an important diagnostic character of Liphyrinae, Miletinae, Lipteninae and Poritiinae; in the latter subfamily their place seems usually to be taken by a semicircle of five terminal spinelets. In the other subfamilies it seems that tibial spurs are always present, though they may be aborted and impossible to see without descaling the tibiae, for example in some Curetinae and in the 
Thecline genus Eumaeus. But I think that Clench attached too much importance to characters of the aborted male fore tarsus, in particular to details of spining on its inner surface. However it is perhaps worth mentioning that in Amblypodia and Iraota the male fore tarsus is spined on its outer as well as on its inner surface, a character which I have not noted elsewhere and which helps to confirm the relationship of these two rather dissimilar looking genera. The type of ending of the aborted male fore tarsus, basically described by Clench as 'stubby-tipped' or 'produced to a ventrally curved point or hook' is sometimes a useful character, for example it is a stubby-tipped in Lipteninae, Poritiinae and in the Thecline tribes Eumaeini, Amblypodiini and Arhopalini (except in Semanga), whilst it tapers to a point in Curetinae, in the Thecline tribes Deudorigini, Hypolycaenini, Tomarini, Oxylidini, Hypotheclini, Catapaecilmatini and Aphnaeini (but rather blunt in Aphnaeus), in Lycaeninae and in the Polyommatine tribes Lycaenesthini, Niphandini and Polyommatini. But in Miletinae (when not segmented and functional) and the other tribes of Theclinae and Polyommatinae it is either intermediate in character or very variable, for example showing a range of characters between the two extremes in Theclini (see Shirôzu \& Yamamoto, I956). I also do not attach as much importance as Clench to the presence or absence of an endodont within the tarsal claw. Admittedly its strong development is a good character of Aphnaeini (as also of the family Pieridae). But in the remaining Lycaenidae it is at best an imprecise character, being often indicated by a slight thickening of the basal part of the claw. Nor do I attach much importance to the general shape of the legs nor to the relative lengths of the various joints. The tribe Miletini shows more strikingly than any other how greatly the shape of the legs may vary amongst closely related genera. In a few instances a joint may end in some form of projection. In Curetinae, as pointed out by Ehrlich (I958), the coxa of the fore leg is produced slightly below its articulation with the trochanter; the same feature occurs in a more pronounced degree in Riodinidae. The rather isolated genus Tomares bears long, pointed, chitinous projections at the end of the tibia, and I consider these to be a good diagnostic character of the monotypic tribe Tomarini, even though rather similar, though considerably smaller, projections occur in some genera of Aphnaeini.

All the Lycaenidae, except Pentilini, have a characteristic middle leg in both sexes. The inner side of the upper end of the tibia has a trough clothed with small (?specialized) scales and partly bordered by a brush of long, narrow scales, which appears to be associated with a blunt, inverted fan of elongated scales near the lower end of the femur. In Pentilini these features are very weakly developed or absent, so that the middle leg resembles that limb in Riodinidae.

\section{Characters OF THE Wings}

(a) Wing shape. Most of the striking abnormalities seem to be of no more than generic value, for example the saw-toothed fore wing costa in Mimacraea, the deeply incised hind wing tornus in Arcas or the false tornus in Acupicta gen. n. (p. 45I, Text-fig. 47A). The absence of a hind wing tornal lobe is a character of Lipteninae, Poritiinae, Miletinae and Polyommatinae (except that a vestigial lobe is present in the Uranothauma and Callictita sections and in some species of 
the Cacyreus section), but in the other subfamilies its presence or absence is of little significance. The absence of hind wing tails is a fundamental character of Lipteninae, Poritiinae, Liphyrinae, Miletinae and Curetinae, whilst the presence of one or more tails, although inconstant, is an equally important character of Theclinae, Lycaeninae and Polyommatinae. In Theclinae the tails or teeth, up to four in number, give very important tribal characters depending on which tail or tooth is dominant. I define as a dominant tail one which occurs only at one vein ending, or one which is longer or, if slightly shorter, then stouter (as in some Iolaini) than any other tail, or, applicable only in Iraota (Amblypodiini), one which alone is present in all the species of a genus, though it may not be the longest in species with two or more tails. A tail at vein $\mathrm{Ib}$ is dominant in Iolaini, Aphnaeini, Hypolycaenini and Amblypodiini, whilst the tail at vein 2 is dominant in all the other tribes except Ogyrini and Luciini, which are somewhat anomalous. Both these tribes are usually tailless but with the hind wing termen toothed or crenulate, especially in Ogyrini, and with the longest and broadest tooth or crenulation at vein 2. However, in a few species of Ogyrini there is a longer, though narrower tooth or tail at veins $\mathrm{Ib}$ or 3 or even at vein 4 in the female, whilst in the Hypochrysops section of Luciini there is a longer tooth at vein 3 in the type-species of Hypochrysops, H. polycletus (L.). In Cheritrini, Catapaecilmatini and Zesiini there is nearly always a tail or strong tooth at vein $\mathrm{Ib}$ and there is never a tail or tooth at vein 3 unless the former is also present, whereas in the remaining tribes in which the tail at vein 2 is dominant (except in Thaduka: Arhopalini) there is no tail at vein Ib even though there may be tails at vein 3 and even at vein 4 . Very frequently the tails are longer or more numerous in the female than in the male. This applies especially commonly in Eumaeini, the most extreme case being Micandra, in which the male has a tailless and uniformly rounded hind wing, whilst the female, long thought be to a separate species, has the hind wing strongly lobed and bearing two tails. In Lycaeninae there is at most a single tail at vein 2, and the same applies to Polyommatini, the remaining tribes of Polyommatinae being always tailless though in Lycaenesthini the hind wing cilia are usually prolonged at veins $\mathrm{Ib}, 2$ and 3 to give a false impression of three short tails.

(b) Venation. The wide use in the past of venation as the primary character has led to many errors in classification. Nevertheless venation remains a character of some importance provided due allowance is made for individual variation, which is probably quite widespread in all groups. Stempffer (I967:2I5) refers to it in Lycaenesthini, whilst I have found it particularly marked in Miletini and in the Thecline tribes Cheritrini, Catapaecilmatini and Iolaini. Abnormalities of fore wing veins I2, II and IO, often including anastomosis or contact of veins II and I2, are a character of Poritiinae, are frequent in Polyommatini where they usually give good section characters, and occur not very rarely in the Epitola section of Liptenini and in Lycaenesthini. Such abnormalities do not occur in Theclinae, except in Jacoona (Iolaini) and in Sithon, Chloroselas and Kopelates (Deudorigini), nor in the Polyommatine tribes Candalidini and Niphandini, nor in Lycaeninae, Curetinae, Liphyrinae and Miletinae. The presence of all twelve fore wing veins is constant in Liphyrinae, is usual in Lipteninae and occurs also in Deramas and Zarona (Poritiinae) 
and in a few genera of Theclinae, where it may be confined to the male sex and appears to be of limited classificatory significance. The reduction of the fore wing veins to ten occurs in many widely separated genera of Theclinae, but is a constant character of Eumaeini, Hypolycaenini, Oxylidini, Hypotheclini, Catapaecilmatini and Horagini. The ending of fore wing vein 7 on the termen when only eleven veins are present is a character of Curetinae which occurs only very rarely in other groups, for example, in Jacoona and females of Amblypodia (Theclinae). Within Theclinae the points of origin of fore wing veins 6 and 7 sometimes give helpful characters and the same may be said of veins 5 and 6 when they arise close together. The presence of a hind wing precostal vein is a fundamental character of Pentilini and of the Durbania section of Liptenini, and occurs also in Megalopalpus, which represents the Ethiopian element in Miletini. In Poritiinae there are indications of a precostal vein which, at its maximum development, comprises a short, broad but rather ill-defined tooth arising from the basal curve of vein 8 ; but in some species these indications are confined to a mere change in the thickness of vein 8 at this point.

(c) Pattern. Within the family there is a standard pattern which has been analysed by Schwanwitsch (I949). It consists of the following markings on the under surface of both wings, the terms used by Schwanwitsch being placed in brackets: a fine marginal line (first externa); a double series of submarginal markings, the outer often macular, the inner often lunulate or linear (second and third externa); a postdiscal macular, linear, catenulate or banded series (first media); a bar or spot at end cell astride the discocellular vein (first discalis); a series passing through the outer half of the cell (second media); and a subbasal series (second discalis). The markings internal to the end cell bar are often absent or distorted, and the other markings give more important and easily used characters. Suppression of any of them does not appear to be of importance, but any drastic distortion of pattern or the addition of further markings are unusual features suggestive of divertent development. The fact that the family pattern is often unrecognizable or strongly modified in Lipteninae, and to a lesser extent in Liphyrinae and Poritiinae, is a fairly good character of these subfamilies suggesting that they branched off the main trunk of the family tree at an early date. Within the other subfamilies the standard pattern is nearly always readily apparent though there are some notable exceptions, for example in Iraota (Amblypodiini). A tendency towards the suppression of all markings on the under surface in quite well separated genera of Papuan or Australian origin, namely Philiris, Parachrysops and Titea (Theclinae), in some Candalidini, and in Parelodina, Vaga and Famegana (Polyommatini), appears to be an example of convergence of little classificatory significance. Mimicry of the standard Batesian type occurs in some genera of Lipteninae, for example in Mimacraea and Mimeresia. Mimicry in a more general sense may explain certain similarities which occur in various not very closely related genera. For example, in the Oriental Region a number of Thecline genera in the tribes Cheritrini, Loxurini, Iolaini, Hypolycaenini and Deudorigini have brown females with the hind wing bearing a large white tornal area against which the 'false head', formed by a large black tornal spot in space 2 and a long tail, stands out very prominently. This accentuation of the 'false head' probably has protective value. If one can speak of a model in a case 
like this, then the species of Cheritrini, in which sexual dimorphism is less marked than in the other tribes and which I believe to be of wholly S.E. Asian origin, are probably the models - or at least the group in which this pattern originally evolved. More perplexing is the occurrence in a number of well separated Papuan genera or species of an aberrant pattern, in which the under surfaces of the wings are white with broad fuscous costal and marginal borders usually ornamented with prominent streaks or lunules of metallic silvery-green, whilst on the upper surface there are usually broad white discal bands or patches. This pattern is characteristic of the Danis section of Polyommatini (except for the curious and equally aberrantly marked little species Psychonotis purpurea (H. H. Druce) comb. n., which is known only from the Loyalty Is) and occurs also in Polyommatini in several species of the Jamides section and in Caleta mindarus (Felder) and in Theclinae in Waigeum (Hypochrysops section of Luciini), in Hypolycaena danis (Felder) (Hypolycaenini), in Hypochlorosis (Hypotheclini), and in Arhopala critala (Felder) comb. n. and A. florinda (Grose Smith) comb. n. This striking and distinctive pattern suggests warning colours and mimicry, in which case the numerous and common species of the Danis section are presumably the models and the remainder the mimics. If this is correct, the Danis section would appear to be the only distasteful group among the Lycaenidae, although Doherty (I889) has suggested rather unconvincingly that some other Oriental species may be protected because of their brilliant colouring.

(d) Colour. Appears to be of very little significance.

\section{Male Secondary Sexual Characters}

A curious feature of these characters is that they may be present or absent in closely related genera and species. Indeed, in a few species of Cheritrini their presence seems to be a matter of individual variation. This inconstancy, however, does not detract greatly from their value as important and often clear-cut taxonomic characters at subfamily, tribe and section level, whilst in some groups their constant absence may be of equal significance. In the larger tribes there is often a 'standard character' which occurs in the majority of the included genera and species and which, if present, enables one to place an unidentified species into its correct tribe without further ado. These standard characters must be of ancient origin, possibly coinciding with, or closely following, the initial branching off of the ancestral stock.

Unfortunately it is not possible to study the component scales of the varied brands and hair brushes in any detail under an ocular microscope; indeed the limited study which Vane-Wright has so kindly undertaken on my behalf, using the scanning electron microscope, has shown that the ocular microscope may give a totally misleading impression of the structure of the scales. The most striking example is provided by the battledore androconia of the Polyommatini (discussed in more detail on pp. 405-406). Every observer so far has seen and figured apparent 'nodules' of indeterminate shape (it alters at every touch of the focusing screw) placed along the ribs, as in Text-figs I39-I45 etc. But under the scanning electron microscope these nodules are proved to be an optical delusion, no doubt due to some interference factor. Not only are the nodules non-existent, but the trabeculae are seen to be much less conspicuous than usual ( $\mathrm{Pl} .5$, figs 28,30$)$. It seems that the outer lamina 
gets easily torn, as in fig. 28 , but such rents do not seem to have any connection with the appearance of the nodules. Another example of an optical delusion occurs in the purple top scales of all the species of Catapaecilma, but in no other purple species that I have examined; it comprises the appearance of rather blurred, wavy transverse lines, as in Text-fig. I24C. Under the scanning electron microscope (Pl. 3, fig. I4) nothing is seen which could explain these lines, which can have no connection with the 'pepper-pot' appearance of the outer lamina in the spaces between the trabeculae, since the pepper-pot character seems to be standard in blue and purple structural scales of Polyommatinae as well as of Theclinae. VaneWright tells me that he has not so far encountered 'pepper-pot' scales, whose internal structure is clearly shown in Pl. 4, fig. I9, in any other group of butterflies. It was thought that they might occur in Riodinidae, but three blue Riodinids specially examined for the character proved to have scales of a completely different type somewhat resembling those of Morpho. It is possible, therefore, that pepper-pot scales may prove to be a good character of Lycaenidae or even of the Theclinae/ Lycaeninae/Polyommatinae branch of the family. ${ }^{3}$

The scanning electron microscope has shown that there is a great range of differences in detail in both ordinary and specialized scales, but unfortunately it cannot indicate whether they have scent or other chemical properties; but assumed scent scales often have anastomosing ribs, as in Pl. 2, fig. II. A detailed study under the scanning electron microscope of the structure of the scales would be a worthwhile task, but very time-consuming and expensive and far outside the bounds of a preliminary study such as mine. Meantime the distinction between scent and ordinary scales must in many cases remain a matter of guesswork.

Secondary sexual characters provide particularly useful characters in Theclinae and Polyommatinae, and I therefore deal with these subfamilies first.

Theclinae are characterized by the frequent occurrence of so-called brands on the wings. These are broadly of two types:-

(a) contrasting patches formed in a variety of ways from apparently normal or only slightly modified scales,

(b) compact patches of specialized scales which are often associated with 'hair brushes'.

I call the first type 'visual brands' since, although their function is not known with certainty, I cannot conceive what purpose they can fulfill other than visual recognition of the male by the female of the species. They occur sporadically in most of

\footnotetext{
${ }^{3}$ Sellier (1971 $a$ ) has shown that the copper scales of Lycaena dispar (Haworth) (Lycaeninae) and the green scales from the under surface of Callophrys rubi (L.) (Theclinae: Eumaeini) are also of the "pepperpot" type (Uvania type of Sellier), thereby providing further evidence that this type of scale may be the sole type of non-pigmentary scale found in Theclinae, Lycaeninae and Polyommatinae. Sellier also figures structural scales of Apatura ilia (Schiff.) (Nymphalidae) and Gonepteryx rhamni (L.) (Pieridae) of the Morpho type found by Vane-Wright in Riodinidae. It is very desirable that the structural scales of the other Lycaenid subfamilies should be examined, as their type should supply evidence of their phylogeny.

In a second paper Sellier (197 $\mathrm{I} b$ ) figures some Lycaenid androconia, including scent scales from the fore wing brand of Strymonidia spini (Schiff.) (Theclinae: Eumaeini). As might be anticipated, the latter agree closely with those found by Vane-Wright in the Neotropical 'Thecla' bitias (Pl. I, figs 4, 5), of the same tribe, but were clothed with a waxy-looking exudation (presumably the dried secretion of the underlying gland) which could be removed by the application of acetic acid.
} 
the Thecline tribes, so that their use in classification is limited; they also occur rarely in some other subfamilies (see below). The simplest way in which they may be formed is by a group of contrastingly coloured scales, as in the hind wing brand of Dapidodigma. Sometimes the component scales are inserted into the wing sockets at a more oblique angle than the surrounding scales so that they reflect light differently. Sometimes the component scales have their edges rolled inwards. More frequently the brand is due to increased opacity, and such brands can be easily detected by holding the insect against a strong light. Opaque brands may be due to an increase in density of the normal top layer of scales, or additional, usually fuscous, scales may be intermixed with them, as in Ritra (Cheritrini), but more often the upper layer of scales is uniform whilst the underlying and invisible layer of fuscous scales has a greater density, as in the Arhopala atosia (Hewitson) speciesgroup. The latter type of opaque brand may appear as no more than a very faint shadow on the wing.

The second type of brand, in which the scales differ from ordinary scales in shape or size, I term 'scent brands'. When occurring on the hind wing in conjunction with a forward (upward) pointing hair brush on the fore wing dorsum they were termed 'androtheca' by Murray (I935 : I8), who suggested they might be direction-finding organs used for detecting female scent. I think the more usual explanation that they are themselves scent diffusing organs is far more likely to be correct. The size and shape of the scent scales and the position of any associated hair brush are of primary importance.

More often than not brands are composed of only one type of scale, and there is not much difficulty in deciding for oneself whether they are visual or scent brands. But in the Eumaeini the brands are often very complex. The standard tribal character consists of a brand at the apex of the fore wing cell. In its simplest form it is composed of a single type of undersized, presumed scent scale. But in the Neotropical species two or more types of scale may be intermixed or, more often, the brand may consist of two or three contiguous patches each composed of scales of a different shape, size or colour. At Text-fig. I22 I give a diagram of a typical three-part brand consisting of a patch of small, round-ended scales (Pl. I, figs 4, 5), a patch of larger, contrastingly coloured scales (Pl. I, fig. 6) and a ring of much broader and larger scales set at an oblique angle to the wing surface. I believe that only the small scales are scent scales and that the other two types serve for visual recognition. The scent patch is invariably placed at or just beyond the cell apex and opposite the antennal club which is probably used to assist in scent diffusion. A single Nearctic species, Satyrium liparops (Boisduval \& Leconte), has an additional scent brand along the outer part of the cubitus and the bases of veins 3 and 4 .

In many Eumaeini presumed visual brands are also placed at the fore wing cell apex, and such brands may be very large, as in Polyniphes dumenilii (Godart), in which the patch is composed of a mixture of large, round-ended buff and black scales. But sometimes the visual brand is placed on some other part of the wing and beyond the reach of the antennal club, as in the large black patch overlapping the basal half of space 2 in Arawacus, thus contributing some negative evidence that only the scent brands have need of an association with the antennal club. 
In Eumaeini there is an unusually large number of different types of secondary sexual character, which very often occur with the standard tribal character. In view of the great number of superficially similar species it is hardly surprising that so many characters have evolved to ensure correct recognition between the sexes. The most striking character is the extraordinary ex-curved hump on the fore wing costa of 'Thecla' gibberosa Hewitson. Another unique character in Lycaenidae, which I entirely overlooked until Clench drew my attention to it, is the possession by Theritas, Pseudolycaena, 'Thecla' hemon (Cramer) and other 'Thecla' species of a flat, but deep pouch lined with specialized scales in space Ib on the under surface of the hind wing. The means of scent diffusion from this pouch is a mystery to me, since there are no associated hair brushes (the abdominal hair brushes, referred to on p. 388 , could not reach it) nor apparent wing musculature which could evert it; conceivably the antennal club might thrust into it when the wings are closed. In another group of species there is a large, dark patch above the dorsum on the under surface of the fore wing and the hind wing costa may have a prominent hump to cover it; there may also be an apparently associated patch of contrastingly coloured but otherwise ordinary scales on the upper surface of the hind wing. As these fore wing brands, owing to their concealed position, cannot serve any visual purpose, I presume that they must be scent brands. Their component scales are larger than ordinary scales and are of common-place, round-ended shape, but their length and width appear to assist specific distinction. For example, in 'Thecla' cyllarissus (Herbst) the scales are outsize and of normal width, in ' $T$ '. carteia Hewitson the scales are the same shape but much smaller, in 'T.' phoster H. H. Druce the scales are much narrower, whilst in 'T.' strephon (Fabricius) there is a mixture of narrow and broad scales. The genera Heterosmaitia and Allosmaitia are unusual for the tribe in possessing tufts on the upper surface of the hind wing possibly associated with brands on the under surface of the fore wing. In the former genus the tuft is in the cell below the origin of vein 7 and is composed of long, cylindrical scales with swollen bases; it appears to be associated with a polished area on the under surface of the fore wing surrounding a small patch of fuscous, but seemingly normal, scales above vein I. I do not know whether the tuft merely helps to diffuse scent from the fore wing brand or whether it itself both secretes and diffuses scent: but in view of the very abnormal shape of its component scales I think the latter is the more likely alternative. In Allosmaitia the hind wing bears a normal erectile hair tuft at the base of vein 7 which appears to be associated with, though it does not lie exactly opposite, a bare and slightly swollen portion of vein I on the under surface of the fore wing surrounded by a brand of small, pale buff scales with their ends crenulate or concave. In this case I feel moderately sure that the fore wing brand secretes scent and that the hind wing tuft exists merely to diffuse it. In Trichonis there is a large brand on the upper surface of the hind wing associated with an equally large brand on the under surface of the fore wing. In both brands the specialized scales, which I assume to be scent scales, are similar and about the same size as ordinary scales. In $T$. theanus (Cramer) (Text-fig. I28) they are reddish brown and taper towards the apex (some scales being almost pointed), whilst in $T$. immaculata Lathy they are pale buff, shorter and rounded. In Micandra (Text-fig. 
I27) there is a large brand on the fore wing disc composed of two types of scale. I suspect that the much elongated scale, which is pale blue, may be a scent scale.

In Tomarini a small scent patch may be present at the fore wing cell apex, just as in Eumaeini, but the smaller scent scales resemble those of Deudorigini and a second, quite separate scent brand may be present on the fore wing, as in Tomares ballus (Fabricius) (Text-fig. I3I). Moreover the relatively long antennae and short fore wing cell must preclude scent diffusion by the antennal club.

In Deudorigini the standard character, present in the large majority of the species, comprises a scent brand bearing very small scales (Pl. I, fig. 2 and Text-fig. I26) on the upper surface of the hind wing about the origin of vein 7 , which is almost always associated with an erectile hair brush (Pl. I, fig. I) on the under surface of the fore wing dorsum. Additional brands may occur, but never unless the standard character is also present. These often comprise a 'trident mark' of scent scales on the fore wing along the basal portions of veins 2,3 and 4, as in many Rapala species, but compact patches may occur. In a few African species of Hypokopelates there is an additional scent brand overlaid by an erectile hair tuft in space $\mathrm{Ib}$ on the upper surface of the hind wing. Some species of Pilodeudorix are highly aberrant in possessing a scent brand on either side of the abdomen, bearing full-length but rather narrow, round-ended scales and there is a large associated hair brush arising near the base of space Ib on the hind wing. The genus Sithon occupies a rather isolated position in the tribe; not only is it alone in possessing only ten fore wing veins, but it also has an additional scent brand on the hind wing just above vein 6 overlaid by an erectile hair tuft arising in the cell and there are further rather prominent, but non-erectile hair tufts near the bases of spaces Ia and Ib on the fore wing and astride vein 2 on the hind wing.

In Hypolycaenini there is no standard character. Scent brands occur in a few of the African species. In Hypolycaena naara Hewitson and $H$. liara $\mathrm{H}$. $\mathrm{H}$. Druce there is a compact patch of undersized scales (Pl. 3, fig. I3) at the lower corner of the fore wing cell, which at first sight recalls the standard scent brand of Eumaeini; but it is nearer the base of the wing and not opposite the antennal club, which could hardly be used to diffuse the scent. In Tatura lebona (Hewitson) there are two scent brands on the fore wing; these comprise a small patch of rather Deudoriginelike scales at the base of space 2 and also a longish pouch lined with small scales and overlaid by an erectile hair tuft along the basal half of vein I. In a few Oriental species visual or partly visual brands are found on the fore wing disc. They are most prominent in the 'Hypolycaena' phorbas species group, in which a trident mark of small, bifid- or trifid-ended scales at the base of veins 2, 3 and 4 is surrounded by a large patch of ordinary scales of a deeper shade than the rest of the wing. I suspect that the trident mark may be a scent brand.

In Iolaini both scent and visual brands are very frequent. Usually the presumed scent scales hardly differ in appearance from ordinary scales and are about the same size or larger. The standard character consists of a scent brand on the hind wing (Pl. 2, figs IO-I2) concealed beneath a lobe on the fore wing dorsum which bears an erectile hair brush turned up beneath the wing, exactly as in Deudorigini. However the hind wing brand differs from the homogeneous brand of Deudorigini in being 
ill-defined and merging into a surrounding nacreous area of round-ended scales. A number of modifications or other types occur, often in single species, giving rise to a number of monotypic or very small genera. In Creon, as well as the standard character, there is an additional small tuft on the fore wing dorsum composed of enormous, loosely attached, boat-shaped scales (Pl. 2, figs 7, 9). In the type-species of Iolaus the usual hind wing brand and surrounding nacreous area are replaced by a black patch which may serve as a visual brand, since the usual concealing lobe of the fore wing dorsum is not developed, whilst there is a small, apparent scent brand on the under surface of the fore wing beneath the usual hair brush. In several genera there are scent brands beneath overlying hair brushes on the upper surface-in Dacalana and Thrix on the fore wing and in Manto and Hemiolaus on the hind wing. In Dacalana (Text-fig. I36) the scent brand is composed mainly of large scales but some much smaller scales are also included, and both types are unusual for the tribe in having crenulate ends. In Hemiolaus (Text-fig. I35), as if to emphasize its intermediate position between the rest of Iolaini and Hypolycaenini, the scent scales are considerably smaller than usual. In a large number of species there are brands on the fore wing disc. These may be purely visual; but in some cases, for example in Britomartis and Jacoona, they may also incorporate scent scales. In both these genera the brand scales are loosely attached and in Jacoona comprise a mixture of normal-sized, round-ended, brown scales and much larger fuscous scales set at an oblique angle to the wing, especially near the edge of the brand where they stand almost upright. In Purlisa a hind wing hair fringe is used in conjunction with a scent brand on the abdomen - an arrangement otherwise found in Lycaenidae only in Pilodeudorix and in Poritiinae-and the presumed scent scales (Text-fig. I29) are outstandingly large. A still more curious feature occurs in Sukidion comprising a prominent two-part hair fringe along almost the whole length of the fore wing dorsum, the shorter whitish part turned down, the longer fuscous part turned upwards beneath the fore wing. As there is no associated scent brand its purpose is conjectural. Could it be a sort of receptor, as visualized by Murray?

In the very small tribe Remelanini secondary sexual characters are present in all but the monotypic genus Pseudotajuria gen. n. (p. 45I). In Remelana there is an indistinct visual brand on the fore wing disc, generally similar to that of the Hypolycaena phorbas group (p. 403) but with the trident mark more obscure and composed of weakly contrastingly coloured but otherwise perfectly ordinary scales. In Ancema there are hind wing scent brands associated with fore wing hair brushes, as in Iolaini. In the type-species, A. ctesia (Hewitson), there are also two large brands on the fore wing, and the scales in all three brands are similar and much smaller than ordinary scales. In $A$. blanka (de Nicéville), a species only provisionally included in Ancema, there are no fore wing brands and the scales in the hind wing brand are larger and do not seem to differ from those of Iolaini. In general the secondary sexual characters of Remelanini corroborate other characters in suggesting that the tribe occupies a position linking Iolaini and Hypolycaenini.

In Cheritrini, Horagini and Loxurini, three tribes which seem to be rather closely related, a variety of scent and visual brands occur. The scent scales, though variable in shape, are about as large as ordinary scales. The position of the scent 
brands is also variable, for example in a long pit on the hind wing in Yasoda (Loxurini), on the under surface of the fore wing in Thamala (Loxurini) and Horaga (Horagini), and on the hind wing at the base of vein 7 but associated with a further brand on the under surface of the fore wing in Drupadia. In the Drina section of Loxurini the scent scales differ much from those of the rest of Theclinae and the brands are on the upper surface of the fore wing, either as a concentrated discal patch, as in Drina discophora (Felder) (Text-fig. I30), or in the form of streaks along and between the veins, as in D. maneia (Hewitson). In the first-named species the brand is composed of a mixture of scent scales and narrow plume scales; in the latter only the scent scales are present. Both types of brand show an astonishing and inexplicable similarity to the brands found in the Uranothauma section of Polyommatini. Hair brushes on the fore wing dorsum never occur in any of these tribes, but there is a small erectile hair-tuft on the hind wing in Cheritra. In some species scent diffusion may occur through friction when the males indulge in the characteristic Lycaenid habit of moving the hind wings alternately up and down when settled.

In Catapaecilmatini the typical species have the basal portion of vein I of the fore wing slightly swollen and densely clothed with small scales resembling the scent scales of Deudorigini and the same scales occur along some of the other veins. In C. major H. H. Druce and C. lila Eliot the corresponding part of vein I is sparsely clothed with short wavy hair scales, (Pl. 3, figs $\left.\mathrm{I}_{5}, \mathrm{I} 6\right)$, but there are no androconia on the other fore wing veins.

In Amblypodiini the genera Iraota and, to a lesser extent, Myrina have the hair scales along the fore wing dorsum and on the hind wing more developed than usual. The development is particularly strong in Iraota rochana (Horsfield) and the fore wing hairs have become a fairly well formed tuft approaching the hair brush found in Deudorigini, Iolaini and Remelanini. The subbasal area of the hind wing bears somewhat polished but barely modified scales which do not give the impression of being scent scales. In addition, in both genera, the groove in space $\mathrm{Ib}$ of the hind wing is rather densely overlaid by hairs, though the underlying fuscous scales appear to be quite normal. I doubt if any of these features amount to a scent diffusion apparatus, but it seems just possible that they represent scent organs either in the early stages of evolution or else in the later stages of degeneration.

In the remaining tribes of Theclinae secondary sexual characters do not occur except for the rare presence of visual brands in Arhopalini.

In Polyommatinae the androconia, using the term in a wide sense to indicate any type of scale not found in the female, play an important part in the separation of the four tribes. In Polyommatini, leaving aside the Uranothauma and Callictita sections, which I deal with separately, since their secondary sexual characters are quite different to those of the rest of the tribe, the androconia are of three main and two subsidiary types:-

(a) Battledore scales (Pl. 5, figs 25-30 and Text-figs I39, etc). These well-known scales have a variable number of ribs, usually parallel but sometimes converging like the ribs of an open fan, which usually appear to bear separate nodules (p. 399). 
They are known to be scent scales. They are present in at least some species of each section except for the Una, Zizula, Pithecops and Cupidopsis sections, which contain so few species that their absence may not be of taxonomic significance, and the Lampides section which bears modified androconia described below as 'long flask scales'. The battledore scales usually provide good characters at the genus and species-group level, and sometimes at section level also, but they may exhibit quite marked individual variation and are often strongly asymmetrical. They are inserted in the wings in alternate rows with ordinary scales, frequently in a one-forone or slightly higher ratio, but may be much sparser than the latter; indeed, in some species in which they are always sparse, such as Zizeeria maha (Kollar), examples may occur in which they are entirely lacking. They are commonest in blue or purple species, but also occur in a number of brown species. The length of their pedicel is roughly in inverse ratio to the length of the lamina, since the combined length pedicel + lamina must be sufficient to enable them to protrude beyond the overlying ordinary scales. Usually the lamina tapers into the pedicel which is widest at the top and integral with the lamina. However, in two genera, Catochrysops (Text-fig. I40) and Rysops gen. n. (p. 452 and Text-fig. I39), the pedicel tapers to a point at its apex and is very lightly attached to the rather rectangular lamina; and, particularly in the latter genus, care has to be taken in extracting the androconia or the pedicel is left behind and the extracted scale, having no trace of a pedicel, appears to be unstalked. This peculiarity, combined with their similar external appearance and pattern, obliges me to unite these two genera in the Catochrysops section despite differences in the male genitalia and venation. Except in the Zizeeria section (Text-figs I4I-I43), Actizera section (Text-fig. I44) and in Itylos (Text-fig. I45) the apex of the scale is convex. In the first two sections the scales are rather large, with a flat base, parallel sides and a concave or flat apex, and the fact that those of Actizera are virtually indistinguishable from those of Zizeeria suggests that Chapman (I9I0) may have been correct in associating these two genera in his 'subfamily' Zizeeriinae and that Stempffer (I967:275) was incorrect in thinking that they have no close relationship. In Theclinesthes (Text-fig. 159) and some Nacaduba species the scales may be wider at bottom than at top. In Pseudonacaduba (Text-fig. I52), Upolampes (Text-fig. I5I) and Azanus (Text-fig. I46) the base of the lamina is concave, as in ordinary scale, and in the first two genera the scales are virtually indistinguishable. I do not think that this necessarily indicates that these three genera are closely related, but rather that evolution of the battledore character from that of the normal scale has proceeded less far. On other grounds the three genera certainly do not seem to be closely related.

(b) Paddle scales (Text-figs I48, I49). These have a hybrid appearance between long plume scales (see below) and battledore scales, and as they never occur in association with the latter they are probably modified battledore scales. They occur, so far as I know, only in a few species of four not specially closely related genera: Azanus, Jamides, Erysichton and Petrelaea. Their arrangement on the wing is similar to that of the battledore scales, but they may be far more numerous, so as to hide the ordinary scales, as in the Azanus ubaldus (Cramer) species-group. 
(c) Long flask scales (Text-fig. I6I). These occur only in Lampides and serve to emphasize the rather isolated position of this monobasic genus. I presume that they also are modified battledore scales.

(d) Long plume scales (Pl. 5, figs 25, 26). These have sometimes been referred to as hair scales or Haarschuppen, but as they are not circular in section this is a misleading name bound to lead to confusion with true hair scales always present on the wings of both sexes. They occur in a very great number of species in addition to battledore scales, and for this reason I assume that they are highly modified ordinary scales without scent properties. They may be scattered sparsely over the wing, or be gathered in patches at a sufficient density to give the area a shadowy look, as in Lampides boeticus (L.), or be gathered in dense raised patches, as in Agrodiaetus ripartii (Freyer). In the latter species the scales are particularly long and the patch looks as though it ought to have scent diffusion properties, but as the brown wings also bear large numbers of ordinary battledore scales it is probable that it is only a visual brand.

(e) Gelbe Schuppe (Text-fig. I5oB). This type of scale, discovered by Courvoisier (IgI6) and so named by him in a very important paper on Lycaenid androconia, appear to be confined to the Polyommatus section; at any rate Courvoisier did not record them, nor have I encountered them, in any other section. They are rather intermediate in appearance between ordinary and battledore scales, and their function is unknown.

In the Uranothauma and Callictita sections androconia of types not found in the other sections occur. Most species bear dense patches or streaks on the fore wing composed of specialized hair scales, often in association with short plume scales (Text-fig. I62). I am uncertain whether one or both types of scale have special properties but as some species only bear hair scales it seems likely that these are scent scales. Species bearing these highly specialized brands never bear battledore scales, but the species $U$. antinorii Oberthür appears to link the Uranothauma section to the remainder of the tribe. It bears androconia (Text-fig. I57) rather intermediate in appearance between short plume scales and battledore scales which are about the same length as ordinary scales. They are not arranged in brands, but are found in alternate rows with the ordinary scales in exactly the same manner as battledore scales except that they are present in far greater numbers. I think that they are undoubtedly scent scales.

In Niphandini (Pl. 4, figs 20-22 and Text-fig. I6o) very curious, flask-shaped and 'hieroglyphically marked' androconia occur in most species in alternate rows with the ordinary scales, as with the battledore scales of Polyommatini. The usual ribs and trabeculae are completely distorted, and no two scales are patterned alike. The pedicel is minute and set at right angles below the base of the scale, so that an extracted scale appears to be unstalked. The unique character of these scales emphasize the isolated position of Niphanda.

In Candalidini dagger scales (Pl. 4, figs. 23, 24 and Text-fig. I56), so-called because Haase $(\mathrm{I} 888: 3 \mathrm{I} 7)$, who first drew attention to them, described their shape as 
'dolchförmig', are the only type of androconia. They are slightly shorter than ordinary scales and taper evenly to their bases, and the lamina bears fine ribs without any suggestion of nodules. They are frequently gathered into a dense 'trident mark' on the fore wing disc, but may be spread over the wing surfaces, usually at a much higher rate than one androconial per ordinary scale.

I have examined many species of African and Oriental Lycaenesthini without finding any androconia other than long plume scales. However battledore scales have been reported by several authors. Bethune-Baker (I9Io), writing of the African species, says: 'the scales of the wings present no points that call for special attention except for the fact that the long (my italics) battledore scales are very few in number'. Fruhstorfer (in Seitz, I924) says of the Oriental species that the battledore scales of Lycaenesthes lycaenina (Felder) are elliptical, like those of Chilades, whilst those of $L$. philo (Hopffer) are leaf-like, like those of the elpis-group of Jamides, but I have failed to find any in either species. Courvoisier (op. cit.) claims to have found them in all the Oriental species but in only one African species, Anthene amarah (Guérin). His figures, in size, shape and pattern of the ribs, appear to represent ordinary blue or purple top scales, which in this tribe often have relatively few and stout ribs. For example, I have found ordinary purple scales of the African $A$. liodes (Hewitson) (Pl. 3, figs I7, I8) with as few as seven stout ribs. For my part, until I have actually seen them, I remain quite unconvinced of the existence of battledore scales in Lycaenesthini, and I consider that their absence is one of the important diagnostic characters of the tribe.

In Lipteninae secondary sexual characters are always confined to the fore wing. The majority of the species have the fore wing veins more or less swollen at their bases, sometimes in both sexes but always to a more pronounced degree in the male. The latter usually have the veins clothed, sometimes thickly, sometimes sparsely, with small, round-ended scales which are often intermixed with, or underlie, the ordinary scales and extend nearly throughout the whole length of the veins. The size of these scales may vary greatly in any one individual, and it is hard to know whether they should be regarded as androconia or not. In the case of those genera and species, for example Phytala elais Westwood, in which the thickened portion of the veins is short and stout and the small scales are gathered into dense homogeneous brands I assume the scales are scent scales. In a few genera the fore wing may bear a long hair fringe just below vein I, whose only function would seem to be to assist in scent diffusion from the specialized scales lying along vein I. In Aethiopana honorius (Fabricius) (Text-fig. I38) the specialized scales on vein I, lying above a hair fringe, are much longer than ordinary scales, but the specialized scales clothing the other veins are of the usual small type. In Herwitsonia the base of vein I is swollen and clothed with short wavy hair scales (Pl. 6, figs 33, 34), showing in this character an astonishing resemblance to Catapaecilma major (p. 405), space Ia bears a rather dense cover of exceptionally long and wavy hairs and the other fore wing veins bear the usual small scales.

In Poritiinae the secondary sexual characters are always confined to the hind wing or abdomen. There are one or two hind wing brands clothed with very small scent scales (Text-fig. ${ }_{337} \mathrm{E}$ ) and usually provided with overlying hair brushes. 
In Poritia, as already mentioned, there is a brand on the abdomen with an associated hair brush on the hind wing. The scales in this brand (Text-fig. I37 A, B, C) are of two types, the long scale probably being the scent scale.

In Liphyrinae the Liphyra section lacks secondary sexual characters, but in all but one of the species of the Aslauga section there is a small scent brand on the upper surface of the hind wing comprising a strip of small specialized scales overlying a short, slightly swollen, subbasal portion of vein 7 . Under an ocular microscope these scales (Text-fig. I33) give the impression of having a granular surface with faint radiating ribs, but under the scanning electron microscope they are seen to have normal parallel ribs. In Aslauga pandora H. H. Druce (a species probably misplaced in this genus) there is a very large brand on the hind wing clothed with long but rather narrow scales, which I assume to be visual scales.

In Miletinae, the males of most of the species of Miletini have the basal portion of vein 4 thickened and bearing a sparse covering of very small scales (Pl. 6, figs 3I, 32 and Text-fig. I34), and in some species this nearly bare portion is surrounded by a visual brand of contrastingly coloured ordinary scales. The small scales, which I assume to be scent scales, are weakly attached, and in worn specimens it is often found that all have become detached, but their empty sockets testify to their original presence. In some species the extent, and even the existence, of the nearly bare portion is a matter of subspecific variation. The remainder of the subfamily lack secondary sexual characters except that in Thestor there may be a visual brand of contrastingly coloured scales on the fore wing.

In Curetinae there are no secondary sexual characters, nor have I found any in Lycaeninae.

\section{EARLY Stages}

Although the early stages of the majority of Lycaenidae are still unknown, sufficient information has been put on record to give considerable assistance in classification. The following résumé of recorded observations appears to support my proposed classification at the subfamily and, often, at the tribal level.

More information has been recorded about larvae in their later instars, to which my remarks about larvae are confined, than about the other immature stages. As, however, larvae must be subject to a greater variety of external factors favouring differential adaptations than the egg or pupa, the later larval instars must have limited value in classification. Bell (I9I5-I920), whose experience of breeding Oriental butterflies remains unrivalled, thought that the pupal stage was more likely to give sound classificatory characters than any other. As long as ago I889, Doherty attempted a higher classification of the Oriental Lycaenidae based solely on the egg, whilst more recently Clark \& Dickson (I956a), in a very important paper, used the egg and first larval instar for their classification of the South African Lycaenidae from the early stages.

Little seems to have been recorded about the eggs of Lipteninae. Clark \& Dickson (op. cit.) figure the egg of Durbania of a most unusual truncated pyramid shape, and also those of some Pentilini shaped like a truncated dome. The egg of Mimacraea, figured by Stempffer (I957), though shaped more like a depressed 
sphere, is broadly similar to that of Pentilini. The larvae of Lipteninae resemble those of the moth families Lymantriidae and Lithosiidae, and differ widely from those of the rest of the family other than Poritiinae. In particular the head is not much narrower than the body and is barely retractile, whereas the standard Lycaenine larva is characterized by a small retractile head. This difference suggests that the Lipteninae and Poritiinae branch originated at a very early stage in the evolution of the family. The usual larval foods of Lipteninae are lichen and microscopic fungi (Jackson, I937). The pupae are fastened only by the cremaster, but appear usually to retain the larval skin bunched up around the posterior segments. They may be suspended or stand out rigidly, head uppermost, at an angle of about $45^{\circ}$ from the support. ${ }^{4}$

The egg of Poritia was described by Doherty (1889) as hexagonal and quite unlike any other egg he knew. It appears to resemble the egg of Durbania more closely than any other. Rosier (I95I) described the larva of Poritia erycinoides (Felder) as long and thin ( $20 \mathrm{~mm} \times 3 \mathrm{~mm}$ when full-grown), rather square in section, barely tapered at either end and with a thick covering of short white hairs arranged in stellate bundles on the back and in 'bushes' on the sides, and with longer, sparser greyish white hairs projecting laterally. It appears to resemble the Liptenine larva quite closely. It feeds on Castanea and apparently is processionary in habit, a feature which appears to be unique in the family, though simple gregariousness has been recorded in several widely separated groups. The pupa is fastened by the cremaster without a girdle, and the abdomen is bent through a right angle so that the main part of the pupa hangs parallel to its support. Rosier does not mention whether the larval skin is discarded or retained, so one must presume the former in the case of this species. But it is of interest, and possibly of taxonomic significance, that de Nicéville (I890:9) records a remarkable similarity between the pupae of Durbania amakosa Trimen and an unnamed Indian Poritia species, both having the posterior end especially densely covered with very long hairs. It seems highly probable that in each case the observer mistook the undiscarded, bunched-up larval skin for an integral part of the pupa.

In Liphyrinae the egg of Liphyra is shaped like a 'drum or section of a Doric column' (Doherty, op. cit.) or 'cheese' (Waterhouse, I932), and is higher than wide. The egg of Aslauga appears to be rather dissimilar, being 'small, white, oval and with a slight central depression' (Jackson, 1937). All known Liphyrine larvae possess a tough leathery cuticle which extends in a wide, skirt-like carapace to the substrate, so that the larvae somewhat resemble limpets. All live in close association with ants and have a wholly aphytophagous diet. The larva of Liphyra lives as an unwelcome guest in the nests of the large and ferocious tree-ant Oecophylla, devouring the ant

\footnotetext{
${ }^{4}$ After studying the recent book by Clark \& Dickson (I97I) and consulting Dickson, it is clear that some of the information given above concerning the early stages of Lipteninae is incorrect. Dickson (pers. comm.) tells me that the egg of Durbania is circular in plan view, though rather peculiarly shaped when viewed from the side. It is apparent that a large, unretracted head in the adult larva has been found only in the few species of the Epitola and Iridana sections whose early stages are known (Farquharson, 1922). In the very few known larvae of the Liptena, Mimacraea and Durbania sections the head, though not fully retracted, is not unduly large; while in the Pentila section the' only known Pentila larva has a small, fully retracted head (Jackson, 1937), and it is evident that the larva of Alaena is similar (Clark \& Dickson, I971: pl. I10).
} 
larvae and pupating wholly within the larval skin inside the ants' nest, from which the imago is able to escape by its possession of a dense covering of specialized and discardable scales in which attacking ants become entangled. On the other hand Euliphyra, which also lives in the nests of Oecophylla, is tolerated by the ants, which feed its larva with regurgitated food (presumably the secretions of Homoptera) even though it contributes nothing to the ant economy, and the pupa, though it does not entirely discard the larval skin, does not derive nor need protection from it (Lamborn, I9I4). The larva of Aslauga feeds on coccids farmed by ants, which do not interfere with it, and the pupa, which has a completely flat under surface and bears chitinanths (chitinous flower-like outgrowths) on top and sides, is attached only by the cremaster whilst the larval skin is entirely discarded (Bethune-Baker, I925).

It might be thought that the tough carapace of the larvae of Liphyrinae had evolved through association with hostile ants. Special protection is certainly needed by Liphyra; on the other hand the larvae of Euliphyra and Aslauga do not appear to need any greater protection from ants than do larvae of other subfamilies which live as more or less unwelcome guests amidst ant communities, for example the larvae of Miletini and Cupidesthes wilsoni Talbot (Lycaenesthini), for which a leathery cuticle without skirt-like carapace suffices. It therefore seems probable that the carapace is not a recent adaptation but an ancient feature which evolved in the original Liphyrine ancestor and is thus of diagnostic significance. The peculiar pupa of Liphyra and the development of discardible scales in its emergent imago are, however, certainly secondary specializations of limited classificatory value.

In Miletinae the egg is of ordinary Polyommatine shape, though often much flattened and disc-like. The egg of Thestor is exceptional in having a lobe on its upper surface (Clark \& Dickson, I960). The larvae are of normal onisciform shape and are carnivorous or feed on the secretions of the honey gland of Homoptera. The pupae may recline under stones or in ants' nests (Thestor), but when above ground are attached only by the cremaster except that Kershaw (I907) states that in Miletus chinensis Felder a girdle is sometimes present. The resemblance of the pupae of Spalgis and Feniseca to a monkey's head is well known, and those of Taraka and Lachnocnema are similarly shaped, though less realistically pigmented. Stempffer (I967) suggests that Clench attaches too great a classificatory significance to the carnivorous habits of this subfamily and of Liphyrinae, mainly on the grounds of the well-known cannibalistic tendencies of many Lycaenid larvae. However a wholly aphytophagous diet is extremely rare in the other Lycaenid subfamiliesit has been recorded in Niphanda fusca (Bremer \& Grey) and two Spindasis species (Shirôzu, I962) and may occur in a few brown species of Pseudodipsas (Sands, in litt.) - so that its $100 \%$ occurrence in Miletinae and Liphyrinae, taken in conjunction with other characters, seems to me to be decisive in supporting their status as subfamilies.

In Curetinae the egg is shaped like a depressed sphere covered with coarse hexagonal reticulations and with a deep central depression at the apex (Bell, op. cit.). The distinctive larva has large, permanently exserted cylinders on the eleventh segment furnished with whip-like, extrusible processes used for scaring away 
unwanted intruders, and lacks a honey gland. The pupa is almost hemispherical with the ventral surface quite flat and is attached by the cremaster and usually by a girdle also. It has been well figured and its other distinctive features discussed by Shirôzu \& Yamamoto (I957).

In Theclinae the egg is usually 'dome-shaped' or shaped like an inverted cup, but occasionally flattened and more resembling an inverted saucer. But sometimes the egg approaches the Polyommatine shape (widest in the middle and with the top flattened or hollowed), for example in a number of Eumaeini, whilst Doherty (op. cit). placed Catapaecilma and Semanga in his subfamily Lycaeninae (recte Polyommatinae mihi) because of their Polyommatine-like eggs.

The larvae of Theclinae are onisciform (widest and highest in the middle, with the dorsal surface gently convex, like a woodlouse) in a number of tribes, for example Theclini, Arhopalini, Ogyrini, Eumaeini. But this shape is often modified to a greater or lesser extent; for example, in Aphnaeini the larva is rather long and parallel-sided, whilst in Iolaini and some other tribes it is waisted and shouldered (i.e. widest and highest about segments 4 or 5), and may be ornamented with numerous fleshy horns (Horagini) or shorter processes (Cheritrini). The tenth segment nearly always bears a honey gland, and the eleventh segment almost as often bears twin eversible tubercles furnished with spines or flagellae. Bell refers to these tubercles as 'signal towers' used to indicate to attendant ants that the honey gland is ready to be milked, but Clark \& Dickson (I956b) state that they are used for 'dusting' and to scare away unwelcome intruders, including ants whose attentions are no longer required. Apparently the larvae of Aphnaeini can always be recognized with certainty by the fact, first pointed out by Bell and confirmed in greater detail by Clark \& Dickson, that the whip-like tubercles are sheathed within permanently raised protuberances protected by spines-an arrangement strongly recalling the much longer cylinders of Curetinae. A further peculiarity of Aphnaeini is that the larvae exude liquid from a saucer-like depression, called a 'dew patch' by Clark \& Dickson, on one or more abdominal segments in addition to the usual honey gland. Apart from the shape and nature of the tubercles, and the different instars in which they first appear, it seems that the widespread association with ants gives little information of classificatory value. Apart from the very few aphytophagous larvae already mentioned (p. 4II) the larvae of Theclinae almost always feed on dicotyledonous angiosperms, at least in their early instars, but some Eumaeini feed on gymnosperms and there are also a very few monocotyledon feeders. The latter include Sandia feeding on bear grass (Clench, in litt.), a few Hypolycaena and Chliaria species on the flowers of orchids, possibly a few species of the Hypochrysops section of Luciini on Smilax, and all the genera of Loxurini whose life histories are known (Loxura, Yasoda, Eooxylides) feeding on Smilax and Dioscorea. If restriction to monocotyledons should be confirmed in the other genera of Loxurini it could, I think, be regarded as an important diagnostic character of the tribe.

The pupae of Theclinae are varied and possibly of considerable diagnostic importance. In the majority of tribes the last segment of the abdomen is dilated in the form of a horse's hoof, round the under surface of which are fixed the suspensory 
hooklets. However, Bell states that this feature is obscure in Catapaecilma and is absent or weakly developed in the Indian species of Aphnaeini, whilst Clench (in litt.) states it is absent in North American Eumaeini. In those genera in which the larva is onisciform or deviates only a little from this shape the pupae are girdled except sometimes when reclining or sheltered or retaining the larval skin (as in Thecla). Girdled pupae are characteristic of Theclini, Eumaeini, Deudorigini, Tomarini, Hypolycaenini, Remelanini, Arhopalini, Ogyrini, Luciini and the Jalmenus section of Zesiini. In genera in which the onisciform shape of the larva is much modified, the pupa lacks a girdle; and as long ago as I9oo, de Nicéville claimed that in India the genera with girdleless pupae formed a natural group. Girdleless pupae seem to be broadly of two types: standing rigidly with head uppermost, often at an angle from a vertical support; or suspended head downwards with the body arched and capable of hammering the head on the support when alarmed (Jackson, I937; also Bell (op. cit.), who records a number of Lycaenid pupae from other tribes capable of making a noise either by hammering or by moving the segments over one another). The first type appears to be characteristic of Horagini, Cheritrini and the Zesius section of Zesiini. It also occurs in Iolaini, but less commonly than the second type, which also occurs in Loxurini and Catapaecilmatini. The tribe Amblypodiini, which in its adult characters appears to occupy an intermediate position between Arhopalini and Iolaini, is also rather intermediate in its pupal characters. In Amblypodia and Myrina the pupa is girdleless and may be suspended, but often reclines in a crevice or on the ground among dead leaves, whilst in Iraota the pupa is particularly strongly attached at the cremaster yet retains a weak girdle (Bell, op. cit.). In Aphnaeini it appears that the pupa is almost invariably without a girdle (Bell records a girdle only in Spindasis vulcanus (Fabricius)), but as the pupae appear to be always enclosed in some form of shelter or reclining on or below ground, sometimes in an ants' nest, its absence is less likely to be of taxonomic significance than in tribes such as Iolaini which always pupate above ground level.

The larva and pupa of Ancema blanka (de Nicéville), described by Bell as Camena argentea, the only species of Remelanini of which any of the early stages are known, are of interest in helping to establish the closer relationship of this tribe to Hypolycaenini than to Iolaini. The larva is onisciform and the girdled pupa is stout, with the belly flattened to fit the substrate closely, and bears a strong likeness in shape and markings to a monkey's head (this resemblance to the pupae of Spalgini must be coincidental). The only point of resemblance to Iolaini is that the larva feeds on Loranthaceae.

The egg of Lycaeninae, characterized by few and very large indentations, is closer to the Thecline dome shape than to the Polyommatine shape. The larva is onisciform and appears always to lack a honey gland though dew patches may be present, as in Aphnaeini. The food plants are nearly always species of dock (Rumex). The pupa is girdled.

The egg of Polyommatinae has been variously described as 'turban shaped', 'mandarin shaped' or 'button shaped'. It is normally widest in the middle with the top flattened or hollowed, but occasionally, as in some species of Lycaenesthini, it shows a slight approach to the Thecline dome shape. The larvae are onisciform 
and are often ornamented with short protuberances of various shapes. Such ornamentation seems to be of less taxonomic significance than in Theclinae; for example, it seems that there are at least three types of larvae in African Anthene (Jackson, op. cit.): perfectly smooth, bearing a single ridge of tent-like processes, double ridged. The larvae, at least in their early instars, feed on dicotyledons except in Niphanda, whilst a few species of Chilades feed on Cycads as an alternative food plant. The aphytophagous larva of Niphanda is abnormal in increasing gradually in width as far as the tenth segment. As in Theclinae, the association with ants is so varied and widespread as to be of little apparent help in classification. The pupae are always girdled except when reclining or sheltered. The Thecline 'horse's hoof', is not developed, except that Bell states it is present 'though not accentuatedly so' in the Oriental species Lycaenesthes emolus (Godart). In Candalidini the pupa is distinctive in having the abdomen flattened at the edges and bears a double or single flat projection at the front of the head (Waterhouse, I932).

\section{SKELETON KEYS TO THE SUBFAMILIES, TRIBES AND SECTIONS}

The following keys have been kept as short as possible. Characters peculiar to the group have been put first, complementary characters subsequently. It does not follow that the former type of character is of primary diagnostic significance, but merely that it is convenient for identification and may dispense with the need to use any complementary characters. In the case of Theclinae, Lycaeninae and Polyommatinae there is a dearth of characters peculiar to the subfamilies and I have therefore been obliged to include sufficient complementary characters to enable any species to be placed in its correct position in the classification.

\section{Key to The Subfamilies}

I Mid and hind tibiae without paired terminal spurs

- Mid and hind tibiae spurred (but spurs may be very small and difficult to see, e.g. in Curetinae and Eumaeus (Theclinae))

(I) Male fore tarsus fused to a single, stubby-tipped segment. Male genitalia with saccus, when developed, directed caudad. Anastomosis of veins II and 12 or abnormalities of veins Io and I I may occur in fore wing

Male fore tarsus segmented and clawed or, if fused to single segment, ending in a down-curved point which may be short and abrupt. Saccus, when developed, directed cephalad. Veins Io, I I and 12 of fore wing normal and separate.

3 (2) Abdomen bearing sparse tufts of bristles on last 2-5 sternites. External secondary sexual characters, when present, confined to hind wing and abdomen.

PORITIINAE (p. 425)

- Abdomen without ventral tufts of bristles. External secondary sexual characters, when present, confined to fore wing.

LIPTENINAE (p. 422)

4 (2) Fore wing with all I2 veins present. Male secondary sexual characters, when present, confined to hind wing

LIPHYRINAE (p. 425)

Fore wing with II veins. Male secondary sexual characters, when present, confined to fore wing and abdomen.

- MILETINAE (p. 426)

5 (I) Antennal shaft bearing sparse fringe of bristles on ventral surface of basal 3-4 segments. Proboscis shaft bearing prominent and regular series of sensillae on sides. Fore wing with II veins and vein 7 ending on termen; hind wing tailless. No secondary sexual characters. 
Antennal shaft without fringe of bristles. Proboscis smooth-sided, but may bear short sensory hairs on under surface in some genera. In species having I I or Io veins, vein 7 ends on costa or at apex, except in tailed genera Jacoona and Amblypodia (female only). Hind wing often tailed. Secondary sexual characters often present $. \quad . \quad . \quad . \quad . \quad . \quad . \quad$.

6 (5) Antennal club cylindrical, except in some species with ro fore wing veins. Hind wing veins often bearing one or more tails which may arise from veins Ib, 2, 3 or 4 , and usually with a tornal lobe. Male scent scales gathered into compact brands often with associated hair brushes .

THECLINAE (p.428)

Antennal club more or less flattened or hollowed beneath, except in most Niphanda females. Fore wing with II veins (except ro in Cupidopsis). Hind wing never with more than a single tail at vein 2 and not lobed, except in some Lycaeninae and vestigially in some species of Uranothauma, Callictita and Cacyreus sections of Polymmatini. Scent scales not gathered into compact brands except in some Candalidini and Uranothauma and Callictita sections, but occur spread over wing surfaces in alternate rows with ordinary scales; hair brushes never present .

7 (6) Male genitalia (Text-fig. 69) with uncus lobes long, curved and digitate; welldeveloped saccus always present; juxta large usually with wing-like appendages. Fore wing with veins 6 and 7 always close at their point of origin, sometimes connate or briefly stalked. No secondary sexual characters.

LYCAENINAE (p. 44I)

Male genitalia variable, but never closely resembling the pattern of Lycaeninae. Fore wing with veins 6 and 7 separate, sometimes widely so. Except in Lycaenesthini secondary sexual characters present more often than not

POLYOMMATINAE (p. 44I)

\section{Key to the Tribes and Sections of Lipteninae}

Under surface of wings with spinules on veins. Palpi very small, shorter than head. Hind wing with precostal vein. PENTILINI, 3 sections. . .

No spinules on veins. Palpi normally developed. Hind wing without precostal vein, except in Durbania section. LIPTENINI, 5 sections

(I) Male genitalia (Text-fig. 7) symmetrical; brachia present; valvae joined by transtilla above penis . . . . . . . Alaena section (p. 423)

Male genitalia asymmetrical, except in Telipna; no brachia; valvae separate

(1) 


\section{Key to the Sections of Liphyrinae}

Fore wing veins 6 and 7 stalked. Palpi shorter than head. Proboscis absent. No secondary sexual characters. Male genitalia (Text-fig. I6) with brachia

Liphyra section (p. 426)

Fore wing veins 6 and 7 not stalked. Palpi longer than head. Proboscis present (except in Aslauga pandora), but may be small. Secondary sexual characters present on hind wing. Male genitalia (Text-fig. I7) without brachia

\section{Key to the Tribes and Sections of Miletinae}

Male fore tarsus fused to a single segment

Male fore tarsus segmented and clawed

LACHNOCNEMINI (p. 427)

(I) Legs normal. Palpi symmetrical. SPALGINI, 2 sections . . . . . 3

Legs abnormal, very long and thin, or flattened and blade-like, or with swollen tibiae. Palpi asymmetrical (but character variable in Taraka) . $\quad$. 4

(2) Fore wing veins 6 and 7 stalked. Nearctic . . . Feniseca section (p. 427) Fore wing veins 6 and 7 separate, latter from before end cell. Oriental and African . . . . . . . . . . $\quad$ Spalgis section (p. 427)

(2) Male genitalia (Text-figs 24, 25) with uncus/tegumen complex not greatly enlarged; brachia absent. Proboscis very small. Fore wing veins 6 and 7

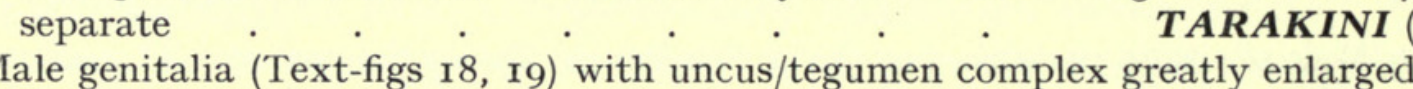
into separate plates; brachia present. Proboscis normal. Fore wing veins 6 and 7 connate or stalked, except in a few species of Allotinus. MILETINI, 2 sections

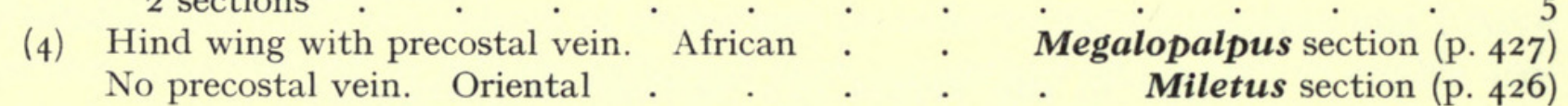

Key to the Tribes and Sections of Theclinae

Hind wing with dominant tail or tooth at vein 2 (but a few species of Ogyrini and Luciini have longest tail or tooth at veins 3 or 4 ) or tailless and with ro or II fore wing veins

Hind wing with dominant tail at vein $\mathrm{Ib}$ (but only bluntly toothed in Gonatomyrina) or tailless and with $\mathrm{I} 2$ fore wing veins (except sometimes in Chrysoritis-see subhead 32)

(I) Fore wing with ro veins and hind wing not tailed at vein $\mathrm{Ib}$. . . . . . Fore wing with I I veins $o r$ with ro veins and hind wing tailed at vein Ib . $\quad . \quad 7$

(2) Male genitalia with juxta. Eyes smooth . . . . . . . . . . . 4 Male genitalia without juxta. Eyes hairy . $\quad . \quad$. $\quad . \quad$. $\quad . \quad$. 5

(3) Antenna with nudum confined to moderately abrupt club; shaft segments about four times as long as wide. No secondary sexual characters. Male fore tarsus ending in tapered, down-curved point .

HYPOTHECLINI (p. 433)

Antenna with gradual club and nudum extending down shaft; shaft segments not much longer than wide. Male with scent brand. Male fore tarsus stubby-tipped. Yasoda, part of Loxura section of LOXURINI

(3) Fore wing veins I I and I 2 touch. Male with hair brush on fore wing dorsum.

Male fore tarsus ends in tapered, down-curved point. Sithon, part of

Deudorix section of DEUDORIGINI (p. 439)

Fore wing veins II and I 2 free. Males never with hair brush on fore wing dorsum. Male fore tarsus stubby-tipped. EUMAEINI, 2 sections $\quad$. $\quad$. 6

(5) Male fore tarsus sybcylindrical and spined throughout. Eumaeus section (p. 440) Male fore tarsus centrally swollen and spined only at tip. Trichonis section (p. 44r) 
7 (2) Hind wing not tailed at vein $\mathrm{Ib}$ (may be toothed). $\quad . \quad$. $\quad . \quad$. $\quad . \quad 8$

$-$

Hind wing tailed at vein $\mathrm{Ib}$

LUCIINI, 2 sections genitalia without juxta THECLINI, 2 sections tail at vein 2

(7) Hind wing tailed at vein 2 or tailless and with antennal nudum extending unbroken below club or with hairy eyes.

Hind wing no tail at vein 2 (may be toothed there). Antennal nudum ending on club or interrupted by bands of scales beginning on club. Eyes smooth.

(8) Male genitalia (Text-fig. 27) with two-pronged uncus; juxta large, Y-shaped.

Male genitalia (Text-fig. 28) with uncus not produced; juxta absent or reduced to a small semi-circular band . . . . Hypochrysops section (p. 429)

(8) Fore wing with veins 6 and 7 connate or stalked _. . . . . . . $\quad$ I I Fore wing with veins 6 and 7 separate (separation may be slight in Deudorigini) I6

(г) Eyes smooth. Palpi not hairy (except in Pseudalmenus). Australian . . I2 Eyes hairy $o r$, if smooth, palpi are hairy. Not Australian . . . . . . I3

(I I) Palpi with third joint very short in male; second joint clothed appressed scales. Fore wing always with I I veins, veins 6 and 7 connate. Hind wing termen usually very crenulate, but not tailed at vein 2 ; rarely with blunt tail at veins Ib, 3 or 4 longer than the crenulation at vein 2. . $\quad$ OGYRINI (p. 43I)

Palpi with third joint at least half as long as second joint; second joint hairy or with some bristly scales. Fore wing sometimes with 12 veins in male; veins 6 and 7 sometimes stalked. Hind wing tail or long tooth at vein 2 longer than any other . . . . Jalmenus section of ZESIINI (p. 432) Legs abnormal, tibiae with large projections at tarsal end TOMARINI (p. 439)

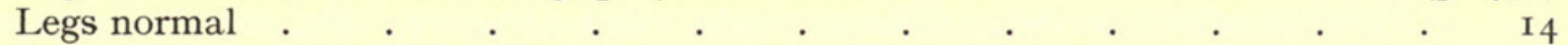

Male with scent brand on hind wing and associated hair brush on fore wing dorsum. Hind wing tailless but produced at tornus. Eyes hairy. Male

Capys section of DEUDORIGINI (p. 439)

No secondary sexual characters. Hind wing not produced except in Amblopala, which has smooth eyes. Male genitalia (Text-figs 29-32) with juxta.

Hind-wing tailless but produced into a long tornal lobe; fore wing apex slightly

truncate . . . . . . . . Amblopala section (p. 430)

Hind wing not produced and usually tailed; fore wing not truncate

Thecla section (p. 430)

Eyes hairy. Male usually with scent brand on hind wing and associated hair

brush on fore wing dorsum . Deudorix section of DEUDORIGINI (p. 439)

Eyes smooth. No scent brands, except on fore wing in some Drina species . $\quad$ I 7

Fore wing origin of vein 5 much closer to vein 6 than to vein 4

Fore wing veins 4,5 and 6 more or less equidistant section of $A$ RHOP

Arhopala section of ARHOPALINI (p. 43I)
. . .

Under surface not white or orange. Hind wing not produced at tornus; tailless or tailed, sometimes at veins 3 and 4 as well as at vein 2 . $\quad . \quad$. $\quad$ I9

Under surface mainly white or orange. Hind wing produced, with long single

Male genitalia (Text-fig. 39) without lateral ridge; valvae ventrally conjoined for at least half their length. Hind wing not tailed at vein 4

Surendra section of $\boldsymbol{A R H O P A L I N I}$ (p. 43I)

Male genitalia (Text-fig. 40) with a lateral ridge (as in Arhopala section); valvae free. Female hind wing tailed at vein 4 as well as at veins 3 and 2

Semanga section of ARHOPALINI (p. 43I) 
2 I (7) Under surface without metallic, silvery markings on all wings.

- Under surface with silvery markings on all wings.

CATAPAECILMATINI, 2 sections

22 (2I) Eyes hairy. Hind wing normally shaped. Male with scent brands on fore wing. Male genitalia (Text-fig. 44) with juxta Catapaecilma section (p. 433) Eyes smooth. Hind wing with false tornus in space $\mathrm{rb}$. No scent brands. Male genitalia (Text-fig. 47) without juxta . . Acupicta section (p. 433)

23 (2I) Fore wing with 12 veins in male; veins 6 and 7 connate.

Zesius section of ZESIINI (p. 432)

Fore wing with ro or I I veins; veins 6 and 7 separate .

24 (23) Antenna with nudum confined to club; shaft segments 3-4 times as long as wide.

Male fore tarsus ending in tapered, down-curved point.

OXYLIDINI (p. 433)

Antenna with nudum continued down shaft; shaft segments less than twice as

long as wide. Male fore tarsus stubby-tipped $\quad$. $\quad . \quad$. $\quad . \quad{ }^{25}$

25 (24) Fore wing with origin of vein 5 much closer to vein 6 than to vein 4 . . $\quad 26$

$-$

Fore wing with veins 4,5 and 6 approximately equidistant .

26 (25) Upper surface mainly blue. Hind wing tail at vein 2 short, about $4 \mathrm{~mm}$. long. Thaduka, part of

Arhopala section of ARHOPALINI

Upper surface mainly white. Hind wing tail at vein 2 broad and about $25 \mathrm{~mm}$ long

Neomyrina section of LOXURINI (p. 434)

27 (25) Hind wing termen stepped at vein 4 as much or more than at vein 3. Male genitalia (Text-fig. 52) with asymmetrical brachia .

HORAGINI (p. 434)

Hind wing termen stepped more at vein 3 than at vein 4 . Brachia symmetrical or absent

28 (27) Male genitalia (Text-fig. 5I) of ordinary pattern, with brachia. Thamala and Eooxylides, part of

Loxura section of LOXURINI (p. 434)

Male genitalia abnormal and without brachia. CHERITRINI, 2 sections .

29 (28) Male genitalia (Text-fig. 53) with juxta and large hood-like structure hinged to valvae and tegumen. African . . . . Dapidodigma section (p. 435)

Male genitalia (Text-fig. 42) without juxta or hood-like structure. Oriental

Cheritra section (p. 435)

30 (I) Fore wing with veins 5 and 6 connate or very close at their origins

AMBLYPODIINI (p. 432)

Fore wing with veins 5 and 6 well separated at their origins except in some Remelanini

3I (30) Palpi very small, less than half length of head. Proboscis very short. Fore wing disproportionately large compared with hind wing

Pseudaletis section of APHNAEINI (p. 436)

Palpi, proboscis and hind wing normally developed

32 (3I) Under surface of fore wing, and often hind wing also, with metallic golden, silvery or nacreous spots or stripes (except in tailless African genus Chrysoritis which often has only II fore wing veins; it resembles a 'Copper' and individuals with II veins work out to subhead 8: Luciini). No secondary sexual characters .

Aphnaeus section of APHNAEINI (p. 436)

Under surface of fore wing without metallic markings. Secondary sexual characters often present

33 (32) In male third joint of palpi at least half as long as second joint. Eyes hairy (except in Pseudotajuria and one Ancema species). Male genitalia without or with only a vestigial juxta.

In male third joint of palpi less than half second joint (except in Pseudiolaus). Eyes smooth (except in Trichiolaus). Male genitalia with juxta.

IOLAINI, 3 sections 
34 (33) Male fore tarsus ending in tapered, down-curved point

Hemiolaus section (p. 437)

$-$

Male fore tarsus stubby-tipped or segmented

. . . 35

5 (34) Antenna with nudum confined to abrupt club. Male abdomen with chitinous structures below the genitalia (Text-fig. 59) Britomartis section (p. 437)

Antenna with rather gradual club and nudum extending down shaft. Abdomen

36 (33) Fore wing with i r veins. Male fore tarsus stubby-tipped.

Iolaus section (p. 436)

Fore wing with ro veins. Male fore tarsus ending in a tapered, down-curved

REMELANINI (p. 437) point

HYPOL YCAENINI (p. 438)

\section{Key to the Sections of Lycaeninae}

Under surface marked as in Polyommatinae. Male fore tarsus ending in a sharp, down-curved point . . . .

Under surface marked as in Theclinae. Male fore tarsus ending in a blunt, rounded point

Heliophorus section (p. 44I)

\section{Key to the Tribes and Sections of Polyommatinae}

Antenna with nudum not crossed by bands of scales. Male fore tarsus ending in a tapered, down-curved point

Nudum crossed by bands of scales almost to tip of club. Male fore tarsus stubby-tipped or briefly tapered to a blunt, rounded point $\boldsymbol{C A N D A L I D I N I}$ (p. 442)

(I) Hind wing cilia elongated into tufts at veins $\mathrm{Ib}, 2$ and 3, except in a few species; never tailed. No specialized scent scales. Male genitalia (Text-fig. 70) with well-developed saccus . . . . LYCAENESTHINI (p. 442)

Hind wing cilia not elongated into tufts, but frequently with a filamentous tail at vein 2. Scent scales usually present. Male genitalia with saccus absent or very weakly developed (except in small Una and Petrelaea sections of Polyommatini)

Antennae exhibit strong sexual dimorphism; in female club long, thin, cylindrical, with nudum extending down shaft almost to base. Male androconia 'hieroglyphically-marked' (Pl. 4, Figs 20-22 and Text-fig. I6o)

Antennae not strongly sexually dimorphic; nudum always confined to club. Androconia various, but never as in Niphandini. POLYOMMATINI, 30 sections .

(3) Fore wing with ro veins . . . . . . . Cupidopsis section (p. 443)

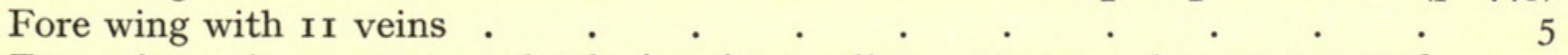

5 (4) Fore wing vein I I not completely free from cell to costa; may be anastomosed with or touch vein $\mathbf{I} \mathbf{2}^{5}$, or be linked to vein $\mathrm{I} 2$ by a short cross-vein . $\quad$. 6

Fore wing vein II completely free from vein I2 . $\quad . \quad$. $\quad . \quad$. $\quad$. 24

6 (5) Male genitalia (Text-figs $75,76,78$ ) with prominent saccus . . . . . . 7

$-$

Saccus absent or weakly developed

(6) Cilia much elongated at hind wing tornus. No scent scales

Una section (p. 443)

Cilia not elongated at hind wing tornus. Scent scales present in two out of three species

Petrelaea section (p. 444)

${ }^{5}$ This character is, unfortunately, not $100 \%$ consistent; for example, in species which normally have veins II and 12 of the fore wing touching, occasional examples may be found in which these veins either anastomose briefly or are completely free. 
8 (6) Fore wing veins II and I 2 do not touch but are linked by a cross-vein

Fore wing veins II and I2 anastomose or touch .

Jamides section (p. 445)

$-$

9 (8) Eyes hairy. Under surface markings catenulate, banded or abnormal or, if maculate, with a fuscous streak below vein $\mathbf{2} 2$ on fore wing

Eyes smooth, except in some species of Zizeeria section with maculate markings but no streak below vein $\mathbf{2} 2$.

ro (9) Male genitalia (Text-figs 8o-88) with brachia absent or vestigial

Brachia present, except in Erysichton (Nacaduba section)

Upolampes section (p. 444)

Under surface with usual Lycaenine pattern greatly modified and usually unrecognisable

Under surface with Lycaenine pattern recognisable

I2 (II) Under surface with black or fuscous costal and marginal borders which absorb all or most of the characteristic Lycaenine markings and sometimes bear metallic silvery streaks or lunules. One aberrant species, Psychonotis purpurea (H. H. Druce), has the under surface of fore wing fuscous with a yellow subapical band and spot end-cell and the hind wing buff bearing an ill-defined reddish postdiscal band. Australian and Oriental

Danis section (p. 444)

Under surface white, yellowish at wing bases, with a black streak from base below the fore wing cell, some small black costal and marginal marks and a subbasal spot on hind wing astride vein la. African Phlyaria section (p. 446)

I3 (II) Androconia (Text-figs I57, I62) (absent in one species, 'Lycaena' heritsia Hewitson) comprise specialized hair scales or short plume scales or a combination of both gathered into raised patches, streaks between the veins or darkened areas; battledore or paddle scales never found. Hind wing sometimes with vestigial tornal lobe

Androconia, if present, comprise battledore or paddle scales. Hind wing without indications of a lobe .

I4 (I3) Male genitalia (Text-figs 90, 9I, I0o) with normal penis; suprazonal portion short. African.
Male genitalia (Text-fig. 89) with penis with foot-stalk; suprazonal portion long and tapered. Papuan .

Callictita section (p. 445)

I5 (I3) Under surface of fore wing with a fuscous streak below vein I2

No fuscous streak below vein 12

Azanus section (p. 448)

Fore wing veins II and I2 touch briefly. Battledore scales (Text-fig. I40) with flat base and pedicel very narrow at its point of attachment. Cato-

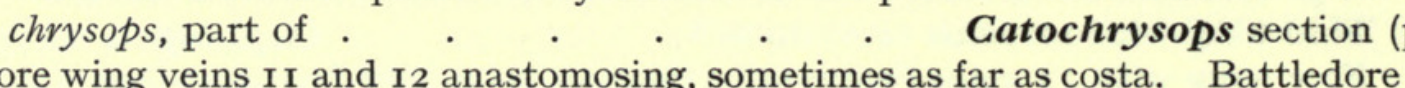
scales with base convex and tapering normally into the pedicel .

I7 (I6) Male genitalia (Text-figs 77, 79) with suprazonal portion of penis short; ductus entering on dorsal surface . . . . . . Nacaduba section (p. 444) Male genitalia (Text-figs 92, 98) with sub- and suprazonal portions of penis subequal; ductus entering cephalad _. . Theclinesthes section (p. 444)

I8 (9) Under surface unmarked except for faintly indicated submarginal series.

Famegana section (p. 447)

Under surface with at least postdiscal markings present $\quad . \quad$. . . . I9

I9 (I8) Under surface no markings internal to postdiscal series except two small costal spots on fore wing . $\quad . \quad$. $\quad . \quad$ Pithecops section (p. 448)

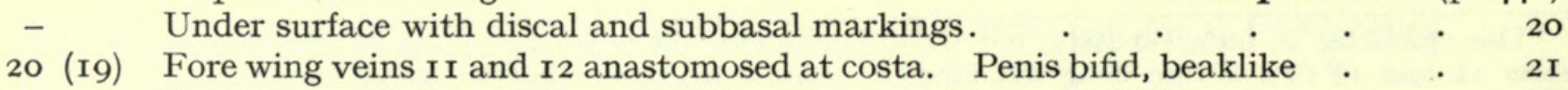

- $\quad$ Fore wing veins II and I2 separate at costa. Penis not bifid . . . 22 
2 I (20) Fore wing with costal spots in spaces 9 and ro on under surface of fore wing. No scent scales. Male genitalia (Text-fig. Iro) without abnormal dorsal

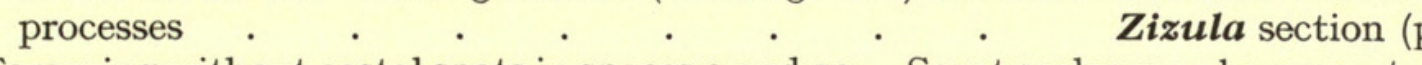

Fore wing without costal spots in spaces 9 and ro. Scent scales may be present. Male genitalia (Text-fig. Io9) with abnormal dorsal processes

(20) Under surface of fore wing with a fuscous streak below vein I2

Brephidium section (p. 448)

Castalius section (p. 447)

No fuscous streak below vein I2, except in Talicada (Everes section) easily recognized by broad, orange marginal area of hind wing .

23 (22) Battledore scales, when present, rounded. Male genitalia (Text-fig. I I6) with undivided uncus . $. \quad . \quad . \quad . \quad . \quad . \quad$ Everes section ( $\mathrm{p}$.

Battledore scales (Text-figs I4I, I43), when present, with upper margin flat or concave. Male genitalia (Text-fig. Io6) with divided uncus

Zizeeria section (p. 447)

24 (5) Androconia, when present, of normal battledore type .

Male with unique, flask-shaped androconia (Text-fig. I6I)

25 (24) Male genitalia with abnormal uncus, lobes not simple .

Lampides section (p. 445)

- Lobes of uncus simple . . . . . . . .

26 (25) Eyes hairy. Uncus lobes bearing a tubercle (Text-figs 102, 103)

Eyes smooth. Uncus lobes double

Cacyreus section (p. 446)

27 (26) Under surface marked like Castalius, with a black streak below vein I2. Male genitalia (Text-fig. I07) without brachia; vinculum broad and rounded.

Zintha section (p. 447)

- $\quad$ No streak below vein I2. Male genitalia (Text-fig II3) with small brachia; lower part of vinculum narrow . . . Eicochrysops section (p. 448)

28 (25) Under surface of fore wing with a fuscous streak below vein I2 (sometimes obscure in Cyclyrius) . $\quad . \quad$. . . . . Leptotes section (p. 446)

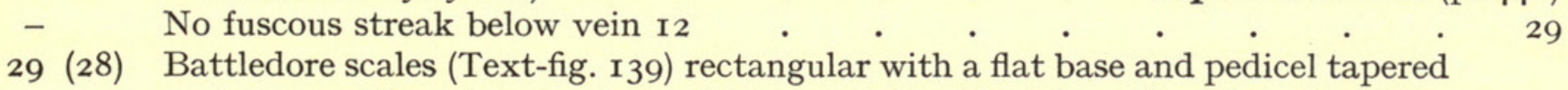
at top and loosely attached. Male genitalia (Text-fig. 96) without brachia.

Rysops, part of . . . . . . . . Catochrysops section (p. 445)

Battledore scales, when present, with base more or less rounded and tapered into the pedicel. Male genitalia with brachia, except in majority of Lycaen-

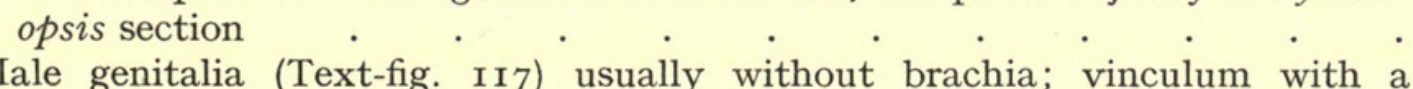

30 (29) Male genitalia (Text-fig. I I7) usually without brachia; vinculum with a
triangular or semi-circular projection directed cephalad; penis with suprazonal portion short, coecum developed . . . Lycaenopsis section (p. 449)

Male genitalia with brachia; vinculum not so strongly produced cephalad; penis without a coecum

3I (30) Male genitalia (Text-fig. I I9) with tegumen reduced; juxta (furca) with short arms . . . . . . . . . . Euchrysops section (p. 449)

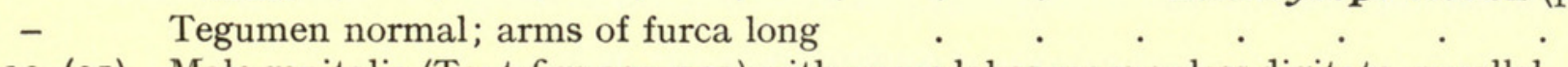

32 (3I) Male genitalia (Text-figs I 2O, I2 I) with uncus lobes more or less digitate, parallel, close together and directed caudad; suspensorium almost always present; penis with alulae at zone $\quad . \quad$. $\quad . \quad$. Polyommatus section (p. 449)

- 33 (32) Battledore scales, when present, rectangular (Text-fig. i44). Penis with ductus entering ventro-cephalad (Text-figs III, II2). African

Actizera section (p. 447)

Battledore scales, when present, rounded. Penis with ductus entering dorsocephalad or cephalad (Text-fig. I I8). Holarctic

Glaucopsyche section (p. 449) 
DIAGNOSES OF SUBFAMILIES, TRIBES AND SECTIONS, WITH A LIST OF INCLUDED NOMINAL GENERA

In each subfamily and tribe I give the name and date of the author who first used the stem of the type-genus in such manner as to constitute a valid family-group name under the current International Code of Zoological Nomenclature. It should not be assumed that the originally included genera and those now included by me are even approximately similar; in some cases no genera are common other than the typegenus. It is perhaps unfortunate that of only four valid Lycaenid family-group names included in the Official List, namely Lipteninae, Pentilini, Strymonidi and Everidi (Cupidinini), the last two fall as subjective synonyms of Eumaeini Doubleday, I847, and Polyommatini Swainson, I827, respectively, which have many years' priority. The butterfly literature is so vast that it is impossible to be certain that the authors and dates are in all cases the earliest. The family-group names listed below should therefore be looked on as provisional, and it is to be hoped that any entomologist spotting an error will bring it to light.

I have aimed to include all Lycaenid generic names other than those which have been placed on the Official Index of Rejected and Invalid Names in Zoology. References to the original descriptions of the genera are not given, since to do so would greatly increase the length of this paper and would merely duplicate the information readily available in Hemming (I967) and Cowan (I968, I970). The order in which nominal genera are listed has no taxonomic significance, but I have tried to position tribes next to their closest relatives - a well-nigh impossible task bearing in mind that evolution is all-directional. I have made no distinction between genera and subgenera, and have shown as synonyms only objective synonyms and preoccupied names which have been superseded by replacement names. I have followed Hemming and Cowan in showing other generic names either as potentially valid and available or as preoccupied and thus invalid. Many genera in the former category have been relegated by other authors, in my view often correctly, to the status of subjective synonyms. Indeed my impression is that far too many genera have been erected for the Holarctic Region, many having no significance above the level of the species-group or even species-subgroup. In other regions, despite the existence of a number of undoubted subjective synonyms a number of new genera are still required and in a later section I make a start by naming and describing several to which I have drawn attention either in text or key.

\section{Family LYGAENIDAE Leach}

Lycaenida Leach, I8I5 : I29. Type-genus: Lycaena Fabricius, I807.

\section{Subfamily LIPTENINAE Röber}

Lipteninae Röber, 1892 : 262. Type-genus: Liptena Westwood, r851.

Fore wing usually with all I 2 veins present, but occasionally with vein 8 absent. Hind wing without tail or tornal lobe; precostal vein sometimes present. Colour and pattern very variable, sometimes mimicking other families; on the under surface the usual Lycaenine pattern is seldom recognizable. Secondary sexual characters, usually present in males, are always confined to the fore wing; these commonly comprise swollen veins clothed with small scales, but patches of specialized scales and hair fringes may be present in addition. Palpi variable; second joint 
usually clothed with appressed scales, but sometimes with bristly or hairy scales. Antennae very variable (see under sections). Proboscis, except when very small and possibly undergoing atrophy, bears few fine sensory hairs on shaft; terminal papillae not strongly developed. Male fore tarsus fused to a single stubby-tipped segment. Mid and hind tibiae without terminal spurs. Male genitalia very variable (see under tribes and sections). Early stages: known larvae are similar to those of Poritiinae, and both differ widely from all other Lycaenid larvae in resembling the larvae of the moth family Lymantriidae, with comparatively broad and barely retractile head and dorsal and lateral tufts of hairs; known foods are lichen and microscopic fungi; pupae are attached by cremaster without girdle and retain the larval skin. Wholly Ethiopian subfamily, divided into two tribes.

\section{Tribe PENTILINI Aurivillius}

Pentilini Aurivillius, I9I4 : 298. Type-genus: Pentila Westwood, I85I.

Fore wing with 12 veins. Hind wing with precostal vein. Under surface with semi-erect spinules on veins; scaling sometimes sparse and may include strongly modified scales (Textfig. 132). Palpi very small, shorter than head. Antenna with abrupt to moderately abrupt club; nudum confined to club (to last four segments in Alaena); segments number about 24-32. Middle leg abnormal, with usual trough on mid-tibia absent or very weakly developed. Male genitalia abnormal and may be asymmetrical; vinculum more or less interrupted and hinged at tergal-sternal suture; saccus directed more or less inflexibly caudad; brush organs apparently never occur. Divided into 3 weakly separated sections on the basis of differences in the male genitalia.

\section{Alaena section}

Male genitalia (Text-fig. 7) symmetrical; brachia present; valvae fused to lower part of vinculum and joined by a transtilla above the penis.

Included genera: Alaena Boisduval, I847; Ptelina Clench, I965.

\section{Pentila section}

Male genitalia (Text-fig. 6) asymmetrical; no brachia; valvae fused to lower part of vinculum; penis very abnormal with an apparently permanently exserted 'flail'.

Included genera: Pentila Westwood, I85I; Liptenara Bethune-Baker, I9I5.

\section{Telipna section}

Male genitalia symmetrical in Telipna (Text-fig. 8), asymmetrical in Ornipholidotos (Text-fig. 9); no brachia; valvae hinged to vinculum at tergal-sternal suture; saccus distally fused to 8 th sternite, which is more strongly sclerotized than usual, and the whole complex capable of up and down movement.

Included genera: Telipna Aurivillius, I895; Ornipholidotos Bethune-Baker, I9I4.

\section{Tribe LIPTENINI Röber}

Under surface without spinules on veins; scaling normal. Palpi longer than head. Midtibia of normal Lycaenine type. Male genitalia with normal vinculum; saccus, when developed, flexible and in its natural position recurved and directed caudad; true juxta absent, but a homologous structure is present comprising a sheath folded round penis and connected to sacculi by a pedicel of varying length; rarely pedicel bears long, paired arms extending dorsad. Divided into 5 sections. 


\section{Durbania section}

Fore wing with 12 veins. Hind wing with precostal vein (absent in remaining sections). Antennae with short, broad and more or less flattened club with nudum confined to its upper half; segments number about 24-32; shaft segments usually about 3-4 times as long as wide. Proboscis very short. Male genitalia (Text-fig. I2) rather variable; brachia present but reduced in Durbania; brush organs apparently do not occur. Rather widely separated from remaining sections and should perhaps rank as a tribe.

Included genera: Durbania Trimen, I862; Cooksonia H. H. Druce, I905; Sheffieldia H. H. Druce, I9I2; Durbaniella van Son, I959; Durbaniopsis van Son, I959.

\section{Mimacraea section}

Fore wing with veins 6 and 7 with a long stalk. Antennae with club variable, sometimes cylindrical and fairly long; nudum confined to club, but more extensive than in Durbania section; segmentation similar. Proboscis of average development (as in succeeding sections). Male genitalia (Text-figs Io, I I) without brachia; in Mimacraea and Mimeresia uncus enlarged and asymmetrical; brush organs apparently do not occur.

Included genera: Mimacraea Butler, I872; Mimeresia Stempffer, I961; Pseuderesia Butler, I874; Teriomima Kirby, I887; Eresiomera Clench, I965; Citr nophila Kirby, I887; Euthecta Bennett, I954; Baliochila Stempffer \& Bennett, I953; Cnodontes Stempffer \& Bennett, I953; Eresinopsides Strand, I9II; Eresina Aurivillius, I898; Toxochitona Stempffer, I956; Argyrocheila Staudinger, I892.

\section{Liptena section}

Fore wing with veins 6 and 7 usually separate though close, occasionally connate or with only a short stalk. Antennae as in Mimacraea section. Male genitalia (Text-figs 3, 13) with brachia present except in a few species of Liptena (an omnibus genus requiring subdivision); brush organs present sometimes.

Included genera: Liptena Westwood, I85I; Falcuna Stempffer \& Bennett, I963; Larinopoda Butler, I87I; Micropentila Aurivillius, I895; Tetrarhanis Karsch, I893; Lectiles Birkett Smith, I960; Leucolepis Karsch, I893, invalid, praeocc.

\section{Iridana section}

Venation more or less as in Liptena section, except that on fore wing vein 2 is strongly bowed down towards vein $\mathbf{I}$ and, in Iridana, vein 7 is incomplete. Antenna with cylindrical club in Teratoneura, but slightly flattened in Iridana; nudum extending down shaft; segments number about $34-42$, those on shaft shorter than in previous sections. Male genitalia (Text-fig. I5) without brachia; brush organs present.

Included genera: Iridana Aurivillius, I920 ( $=$ Iris Staudinger, I89I; Iridopsis Aurivillius, I898, praeocc.); Teratoneura Dudgeon, I909.

\section{Epitola section}

Fore wing with veins 6 and 7 widely separated at origin, vein 7 from well before end cell; veins Io, II and I2 sometimes abnormal, veins II and I2 may be anastomosed or veins ro and I I may be connate or stalked. Antennae with cylindrical club and nudum extending down shaft, except in Epitolina (which is 'odd man out' in several respects and possibly deserves to be placed in a section by itself); segments number up to 48 and may be rather short on shaft. Male genitalia (Text-fig. I4) with brachia, except in Pseudoneaveia; brush organs occur in all genera except Epitolina and Batelusia (Pseudoneaveia not examined); scales of brush organ may be very long and thin (e.g. in Phytala, Hewitsonia, Powellana). 
Included genera: Epitola Westwood, I85I; Deloneura Trimen, 1868; Ebepius Hemming, I964 (= Poultonia Neave, I904, praeocc.); Batelusia H. H. Druce, I9Io; Tumerepedes Bethune-Baker, I9I3; Pseudoneaveia Stempffer, I964; Neaveia H. H. Druce, I9Io; Epitolina Aurivillius, I895; Stempfferia Jackson, I962; Phytala Westwood, I85I; Neoepitola Jackson, I964; Aethiopana Bethune-Baker, I9I5; Hewitsonia Kirby, I87I (= Corydon Hewitson, I869, praeocc.), Powellana BethuneBaker, I908; Hypophytala Clench, I965.

\section{Subfamily PORITIINAE Doherty}

Poritinae Doherty, I 886 : I Iо. Type-genus: Poritia Moore, I886.

Fore wing with Io, II or I 2 veins; vein I I always anastomosed with vein 12 and sometimes with vein ro also. Hind wing with a very short precostal vein or indications thereof; no tail nor tornal lobe. On under surface the normal Lycaenine pattern may be much modified. Secondary sexual characters comprise scent brands usually overlaid by erectile hair tufts on hind wing and, in Poritia, brands on the sides of the abdomen associated with hair fringes on the hind wing. Eyes nearly always smooth (hairy in a few species of Deramas.) Antennae with cylindrical club and nudum extending down shaft; segments vary between 30 and 48; shaft segments about $\mathrm{I}_{\frac{1}{2}-2}$ times as long as wide. Palpi of average development, clothed with appressed scales. Male fore tarsus fused to a single stubby-tipped segment. Mid and hind tibiae without terminal spurs. Ventral surface of abdomen in both sexes bears sparse tufts of bristles on last 2-5 unmodified segments. Male genitalia with brachia; saccus, when developed, directed caudad; true juxta absent, but in Cyaniriodes (Text-fig. 5) there is a homologous structure resembling the sheath and pedicel of Liptenini. In Deramas (Text-fig. 4) and Zarona a similar structure is present, but the pedicel is directed between and not connected to the sacculi, which bear crescent-shaped sclerites which loosely embrace the lower half of the penis distad of the sheath. Early stages: egg hexagonal; larva (see p. 4Io) Lymantriid-like, phytophagous, gregarious and processionary; pupa suspended by cremaster without girdle. No tribes or sections. Oriental.

Included genera: Poritia Moore, I886; Simiskina Distant, I886; Cyaniriodes de Nicéville, I89o; Poriskina H. H. Druce, I895; Deramas Distant, I886; Zarona de Nicéville, I888; Massaga Doherty, I889, praeocc.

\section{Subfamily LIPHYRINAE Doherty}

Liphyrinae Doherty, I889 : 409. Type-genus: Liphyra Westwood, I864.

Fore wing with $\mathrm{I} 2$ veins; veins Io, I I and $\mathrm{I} 2$ free. Hind wing tailless. On under surface the standard Lycaenine pattern is not recognizable. Eyes smooth. Palpi clothed with appressed scales; may be very small. Antennae short and stout, with cylindrical and usually gradually incrassate club; nudum extending down shaft; segments number about 30-44; shaft segments usually about as wide as long. Proboscis usually wholly or partially atrophied, but when normally developed bears a regular series of fine sensory hairs on shaft. Male fore tarsus segmented, clawed and fully functional. Mid and hind tibiae without terminal spurs. Male genitalia rather commonplace (see under sections). Early stages: larva with skirt-like carapace, wholly aphytophagous, living in ants' nests or in close association with ants; pupa attached by cremaster without girdle, sometimes within, or retaining, the larval skin. No tribes, but divided into 2 sections. Mainly African, with weak representation in Oriental and Australian Regions 


\section{Liphyra section}

Large species. Male without secondary sexual characters. Palpi very small, shorter than head. Proboscis wholly atrophied. Male genitalia (Text-fig. r6) with brachia; tegumen strongly recurved cephalad.

Included genera: Liphyra Westwood, I864 (= Sterosis C. \& R. Felder, I865); Euliphyra Holland, I890.

\section{Aslauga section}

Small to moderate-sized species. Male with a small scent brand on hind wing, bearing very small scales, near the base of vein 7 , except in $A$. pandora $\mathrm{H}$. H. Druce, which has a subcostal, probably visual, hind wing brand bearing large, fuscous scales. Palpi of average development. Proboscis variable, normally sized, very small or even completely aborted. Male genitalia (Text-fig. 17) without brachia; tegumen not much recurved. Wholly African.

Included genera: Aslauga Kirby, I890; Paraslauga Bethune-Baker, I924; Egumbia Bethune-Baker, I924; Euliphyrodes Romieux, I937.

\section{Subfamily MILETINAE Corbet}

Gerydinae Doherty, I886 : ıго. Type-genus: Gerydus Boisduval, r836 [= Miletus Hübner, I8I9].

Miletinae Corbet, I939: 63. [Valid under Article 40a of the Code.] Type-genus: Miletus Hübner, I8r9.

Fore wing with II veins, veins Io, II and I 2 free. Hind wing tailless and lobeless. On under surface normal Lycaenine pattern nearly always readily recognizable. Antenna with cylindrical club; nudum extending down shaft, except in one species of Taraka. Eyes smooth, except in Lachnocnema. Palpi variable, sometimes asymmetrical. Proboscis bears a series of fine sensory hairs on shaft, except when partially atrophied. Male fore tarsus segmented or fused to a single segment. Mid and hind tibiae without terminal spurs. Male genitalia very variable, but valvae always dorsally united by a membrane or some form of transtilla-like structure. Early stages: egg round, flattened, disc-like; larva onisciform, wholly aphytophagous; pupa suspended by cremaster, usually without girdle, or reclining on or below ground. Oriental and African, with weak representation in Holarctic Region. Divided into 4 tribes.

\section{Tribe MILETINI Corbet}

Fore wing with secondary sexual characters sometimes present, comprising a swollen portion of vein 4 rather sparsely clothed with small specialized scales (Pl. 6, figs 3I, 32 and Text-fig. I34). Antenna with gradually incrassate club; nudum extending down shaft to base or very nearly so; segments number from about 36 to 62 ; shaft segments short, usually slightly longer than wide. Palpi long, asymmetrical; basal fleck bears a tuft of (?) sensory hairs. Male fore tarsus fused to a single segment and ending in a short, abrupt point. Legs more or less abnormal, very long and thin or flattened and blade-like or with mid and hind tibiae much swollen towards their lower ends. Male genitalia with uncus and tegumen developed into enormous paired plates; brachia present; valvae small, dorsally united by a weakly sclerotized transtilla cephalad of vinculum. Divided into 2 sections.

\section{Miletus section}

Hind wing without precostal vein. Male genitalia (Text-fig. I8) with uncus/tegumen plates subrectangular; brachia almost straight. Oriental.

Included genera: Miletus Hübner, I8I9 (= Symetha Horsfield, I828; Gerydus Boisduval, I836); Miletographa Röber, I892; Archaeogerydus Fruhstorfer, I9I6; 
Allotinus C. \& R. Felder, I865; Paragerydus Distant, I884; Logania Distant, I884 (= Malais Doherty, I889).

\section{Megalopalpus section}

Hind wing with precostal vein. Male without secondary sexual characters. Male genitalia (Text-fig. I9) with uncus/tegumen plates triangular and bearing a broad, lobe-like process directed ventrad; brachia curved. African.

Included genus: Megalopalpus Röber, I886.

\section{Tribe TARAKINI trib. $\mathbf{n}$.}

Type-genus: Taraka Doherty, I889.

Only two very small species. No secondary sexual characters. Antenna with well-defined, cylindrical club; nudum extending down shaft in $T$. hamada $\mathrm{H}$. Druce but confined to club in T. mahanetra Doherty; segments number about 29-3I; shaft segments about 3 times as long as wide. Palpi usually slightly asymmetrical. Male fore tarsus fused to a single segment and ending in a down-curved point. Tibiae somewhat swollen, especially mid-tibia. Male genitalia with uncus deeply divided into rather large, flat plates in T. hamada (Text-fig. 25), but not in T. mahanetra (Text-fig. 24); no brachia; valvae disto-dorsally conjoined by a strong membrane and ventrally conjoined for most of their length. Larvae feed on coccids. Oriental, just extending into Palaearctic Region.

Included genus: Taraka Doherty, I889 (= Taraka de Nicéville, I890).

\section{Tribe SPALGINI Toxopeus}

Spalgiinae Toxopeus, I929: 218. Type-genus: Spalgis Moore, I879.

Small species without secondary sexual characters. Palpi symmetrical. Male fore tarsus fused to a single segment ending in a down-curved point. Male genitalia with uncus not, or not much, excavate; brachia present. Larvae feed on coccids; pupae resemble a monkey's head in miniature. Divided into 2 sections.

\section{Spalgis section}

Fore wing with veins 6 and 7 separate, the latter from before end cell. Antenna with club gradually incrassate; segments number about 33; shaft segments about $\mathrm{r} \frac{1}{2}$ times as long as wide. Male genitalia (Text-fig. 22) with valvae disto-dorsally joined by a weak membrane. Oriental and African.

Included genus: Spalgis Moore, I879.

\section{Feniseca section}

Fore wing with veins 6 and 7 stalked. Antenna with club better defined than in Spalgis; segments number about 26. Male genitalia (Text-fig. 23) with valvae proximo-dorsally joined by a transtilla. Single Nearctic species.

Included genus: Feniseca Grote, I869.

\section{Tribe LAGHNOGNEMINI Clench}

[Luciidi Reuter, I896: 55I.] ${ }^{6}$

Lachnocnemini Clench, I955 : 266. Type-genus: Lachnocnema Trimen, I887.

Thestorinae Clench, I955: 266. [Preoccupied by Thestoridi Tutt, 1907.]

${ }^{6}$ Based on 'Lucia' bibulus (Fabricius), the type-species of Lachnocnema, which is unrelated to true Lucia. Application will be made to the International Commission on Zoological Nomenclature for the suppression of Luciidi Reuter and for the validation of Luciinae Waterhouse \& Lyell, I9I4. 
Small to medium-sized species without secondary sexual characters, except that a visual brand of contrastingly coloured scales may be present on the fore wing of Thestor. Antenna short and stout; club gradual; segments number about 30 ; shaft segments slightly wider than long in Thestor, but rather longer in Lachnocnema. Male fore tarsus segmented, clawed and fully functional. Male genitalia (Text-figs 20, 2I) with brachia; valvae incompletely joined dorsally by labiles. African.

Included genera: Lachnocnema Trimen, I887; Thestor Hübner, I8I9 (= Arrugia Wallengren, I872).

\section{Subfamily GURETINAE Distant}

Curetaria Distant, I884 : I96. Type-genus: Curetis Hübner, I8I9.

Fore wing with I I veins; veins Io, I I and I 2 free; vein 7 ends on termen. Hind wing tailless. No secondary sexual characters. Normal Lycaenine pattern recognizable on silvery white under surface. Eyes hairy. Palpi of average size, clothed with appressed scales. Antenna with cylindrical and rather gradual club; nudum extending down shaft almost to base; segments number about 44 to 48 ; shaft segments a little longer than wide; in both sexes the shaft bears on its ventral surface near the scape a sparse fringe of bristly sensillae of unknown function. Proboscis with prominent series of sensory hairs on shaft; terminal papillae strongly developed. Male fore tarsus fused to a single segment and ending in a tapered, down-curved point. Mid and hind tibiae with inconspicuous terminal spurs. Male genitalia (Text-fig. 26) Riodinid-like; uncus large and hood-like; brachia present; valvae dorsally joined by a central plate above the penis. Early stages: larva with long, permanently exserted cylindrical tubercles on IIth segment; pupa almost hemispherical, ventral surface flat, fastened by cremaster and weak girdle. Oriental, just extending into Palaearctic Region.

Included genus: Curetis Hübner, I8I9 (= Phaedra Horsfield, I829; Anops Boisduval, r836).

\section{Subfamily THECLINAE Swainson}

Theclanae Swainson, I831 : pl. 85. Type-genus: Thecla Fabricius, I807.

Fore wing with Io, II or I 2 veins; vein 7 ends on costa or at apex when only ro or I I veins are present, except in male of Jacoona and female of Amblypodia; veins II and I 2 nearly always free. Hind wing without precostal vein; sometimes tailless but usually with $\mathbf{I}, 2$ or 3 , very rarely 4, tails; sexual dimorphism in length and number of tails frequent; tornal lobe usually developed. On under surface the normal Lycaenine pattern is usually readily recognizable. Secondary sexual characters often present, most commonly comprising patches of specialized scales on fore wing or hind wing which may be associated with erectile hair brushes. Eyes smooth or hairy. Palpi very variable. Antennae nearly always with a cylindrical club, but a flattened club occurs in a few genera of Eumaeini and Hypolycaenini; nudum variable in extent, may be confined to club or may extend down shaft in an unbroken taper or in a series of detached patches; nudum frequently more extensive in female than in male. Proboscis with a smooth shaft except in some genera of Neotropical Eumaeini bearing short sensory hairs on the inner surface. Male fore tarsus usually fused to a single segment, but segmented, clawed and fully functional in a few apparently widely separated genera. Mid and hind tibiae with paired, terminal spurs, but these are rather inconspicuous in a few genera and are almost completely aborted in Eumaeus. Male genitalia very variable; penis more constant than any other component, almost always widely open on its dorsal surface for the reception of the ductus and with the suprazonal and 
subzonal portions usually more or less subequal; brush organs occur frequently in Neotropical genera of Eumaeini. Early stages: egg usually dome-shaped, often flattened on top, more rarely turban-shaped and resembling the egg of Polyommatinae; larvae most often more or less onisciform, but sometimes prominently shouldered or waisted; pupae usually girdled, but in a few tribes may be attached only by the cremaster; last pupal segment usually dilated in the form of a horse's hoof. Cosmopolitan.

\section{Tribe LUGIINI Waterhouse \& Lyell stat. $\mathbf{n}$.}

Luciinae Waterhouse \& Lyell, I9I4 : I I I. Type-genus: Lucia Swainson, I833. ${ }^{7}$

Fore wing with II veins; origin of vein 7 variable, may be separate from, connate or stalked with vein 6 . Hind wing tailless, but termen usually slightly crenulate or toothed. No secondary sexual characters. Eyes smooth. Antennae with cylindrical, moderately abrupt club; nudum variable, may be entire and confined to club (most species of Philivis) or may be crossed by bands of scales commencing about half-way down club and continued down shaft in detached patches; segments number about 25-36; shaft rather narrow, with segments about 3 or 4 times as long as wide. Palpi with second joint clothed with appressed scales or, rarely, with bristly scales. Male fore tarsus segmented and clawed in Titea, otherwise fused to a single segment which is usually stubby-tipped but may be tapered into a point of varying abruptness. Early stages: larvae more or less onisciform, but may be rather parallel-sided or very slightly waisted; pupa girdled or reclining in ants' nests. Australian and Papuan, with very slight extension into S.E. Asia. Divided into 2 sections.

\section{Lucia section}

Males soberly coloured black or brown with limited blue areas or copper. Under surface with normal Lycaenine pattern complete and not ornamented with metallic or silvery markings Male fore tarsus pointed. Male genitalia (Text-fig. 27) with 2-pronged uncus and prominent Y-shaped juxta. Mainly Australian.

Included genera: Lucia Swainson, I833; Paralucia Waterhouse \& Turner, I905; Pseudodipsas C. \& R. Felder, I860.

\section{Hypochrysops section}

Males usually brightly coloured blue, green, purple or coppery orange, rarely white or brown. Under surface almost always with pattern either more or less obsolete or rather distorted and ornamented with metallic silver or green markings. Male fore tarsus stubby-tipped or weakly pointed (except in Titea). Male genitalia (Text-fig. 28) with uncus not produced; juxta absent or reduced to a small semi-circular band.

Included genera: Hypochrysops C. \& R. Felder, I860; Waigeum Staudinger, I895; Philivis Röber, I89I; Parachrysops Bethune-Baker, I904; Titea gen. n. (p. 452).

\section{Tribe THEGLINI Swainson}

Fore wing with I I veins; veins 6 and 7 connate or stalked from apex of cell. Hind wing never with more than a single tail at vein 2. No secondary sexual characters. Eyes hairy or smooth. Antenna with cylindrical club; nudum extending down shaft, sometimes almost to base, in a taper or series of detached patches of decreasing size. Palpi with second joint almost always clothed with hair-like scales. Male fore tarsus exceptionally variable (see under sections). Male genitalia rather variable, but juxta always present, and also brachia except in Austrozephyrus. Early stages: larvae onisciform; pupa girdled, unless reclining or retaining larval skin. Mainly Sino-Himalayan with Palaearctic affinities, extending weakly into Nearctic Region and Sundaland.

${ }^{7}$ See footnote 6 on p. 427 . 


\section{Thecla section}

Wing shape commonplace. Hind wing usually tailed or toothed at vein 2 and with a small tornal lobe, but tailless and lobeless in a few genera. Eyes smooth to densely hairy. Antenna with moderately well-defined club; segments number less than 40 . Male fore tarsus segmented and clawed in 5 genera; in remainder fused to a single segment whose end varies from a tapered down-curved point to a blunt, slightly recurved tip. Male genitalia variable, especially in respect of uncus, which most often comprises the usual two lobes separated by a shallow depression (Text-figs 29, 30), but in some genera there are single or double processes (Text-fig. 3I) sometimes of great length. A large section which might be further divided as in the three paragraphs below, corresponding to the three main branches of the phylogenetic tree figured by Shirôzu \& Yamamoto (I956).

Included genera: Artopoetes Chapman, I9o9; Laeosopis Rambur, I858; Thecla Fabricius, I807 (= Zephyrus Dalman, I8ı6; Aurotis Dalman, I8r6; Ruralis Tutt, I906); Shirozua Sibatani \& Ito, I942; Cordelia Shirôzu \& Yamamoto, I956; Gonerilia Shirôzu \& Yamamoto, I956; Coreana Tutt, I907 (= Bergmania Bryk, I946); Ussuriana Tutt, I907.

Chaetoprocta de Nicéville, I89o; Protantigius Shirôzu \& Yamamoto, I956; Leucantigius Shirôzu \& Murayama, I95I; Ravenna Shirôzu \& Yamamoto, I956; Antigius Sibatani \& Ito, I942; Wagimo Sibatani \& Ito, I942; Araragi Sibatani \& Ito, I942.

Japonica Tutt, I907; Hypaurotis Scudder, I876; Habrodais Scudder, I876; Euaspa Moore, I884; Howarthia Shirôzu \& Yamamoto, I956; Teratozephyrus Sibatani, I946; Esakiozephyrus Shirôzu \& Yamamoto, I956; Neozephyrus Sibatani \& Ito, I942; Chrysozephyrus Shirôzu \& Yamamoto, I956; Iratsume Sibatani \& Ito, I942; Favonius Sibatani \& Ito, I942; Quercusia Verity, I943; Austrozephyrus Howarth, I957; Dipsas Westwood, I85I, invalid, praeocc.

\section{Amblopala section}

Wing shape abnormal; fore wing with apex weakly truncate; hind wing tailless but with tornus drawn into a very long lobe. Under surface aberrantly marked, with a whitish Y-band crossing the hind wing. Eyes smooth. Antenna rather short and stout with a moderately abrupt club; segments number about 40-42. Male fore tarsus fused to a single segment ending in an abruptly tapered point. Male genitalia (Text-fig. 32) commonplace.

Included genus: Amblopala Leech, I893.

\section{Tribe ARHOPALINI Bingham}

Arhopalinae Bingham, 1907 : 284. Type-genus: Arhopala Boisduval, I832.

Fore wing with II veins; veins 6 and 7 separate, latter from before end cell. Hind wing tailless or with up to three tails, that at vein 2 the longest. No secondary sexual characters, other than very occasional occurrence of faint visual brands due to increased density of underlying fuscous scales. Eyes smooth. Antenna with gradual, cylindrical club and nudum continuing in a taper down the shaft; segments number more than 40 ; shaft segments at most only a little longer than wide. Palpi clothed with appressed scales, third joint short. Male fore tarsus fused to a single segment, more or less stubby-tipped, but often slightly recurved and briefly and bluntly pointed (best seen in Semanga). Male genitalia commonplace, brachia and juxta always present. Early stages: larva more or less onisciform, rather flattened in Arhopala section and slightly shouldered in Surendra; pupa girdled. Oriental, with slight extension into the Palaearctic Region. Divided into 3 sections. 


\section{Arhopala section}

Fore wing with vein 5 arising much closer to vein 6 than to vein 4 . Hind wing tailless or, more often, tailed at vein 2; rarely an additional tail at vein 3 and in Thaduka at vein rb also; never tailed at vein 4. Male genitalia (Text-fig. 33) with a prominent internal lateral ridge.

Included genera: Arhopala Boisduval, I832; Narathura Moore, I879; Nilasera Moore, I88I; Panchala Moore, I882; Satadra Moore, I884; Darasana Moore, I884; Acesina Moore, I884; Aurea Evans, I957; Thaduka Moore, I879; Apporasa Moore, I884; Mahathala Moore, I878; Flos Doherty, I889.

\section{Semanga section}

Fore wing with veins 4,5 and 6 more or less equidistant at their origins. Hind wing tailed at veins 2 and 3 in male and with a third tail at vein 4 in female. Male genitalia (Text-fig. 40) with a somewhat weaker lateral ridge than in Arhopala section.

Included genera: Semanga Distant, I884; Keraunogramma Röber, I887; Mota de Nicéville, I890.

\section{Surendra section}

Fore wing venation as in Semanga section. Hind wing never tailed at veins $\mathrm{rb}$ and 4 . Male genitalia without a lateral ridge; valvae ventrally conjoined (as in Deudorigini) for at least half their length; subscaphium very strongly developed and fused to brachia in Surendra, but in Zinaspa (Text-fig. 39) the brachia are free.

Included genera: Surendra Moore, I879; Zinaspa de Nicéville, I890.

\section{Tribe OGYRINI Waterhouse \& Lyell stat. $\mathbf{n}$.}

Ogyrinae Waterhouse \& Lyell, I9I4 : I I4. Type-genus: Ogyris Westwood, I85I.

Fore wing with I I veins; veins 6 and 7 connate from apex of cell. Hind wing usually tailless, but termen often highly crenulate and bearing stout teeth, that at vein 2 being usually the most prominent; but occasionally a longer, stout tail may be present at vein 3 in males or 4 in females. No secondary sexual characters. Eyes smooth. Antenna with gradual, cylindrical club and tapered nudum extending down shaft almost to base, the lower part often as a series of detached patches; segments number about 45; shaft segments hardly wider than long. Palpi clothed with rather long appressed scales; third joint very short. Male fore tarsus fused to a single segment ending in a short down-turned point. Male genitalia (Text-fig. 34) with juxta and brachia. Early stages: larvae onisciform, always on Loranthaceae; pupae girdled, in crevice on or below ground. Australian, with weak extension into Papua.

Included genus: Ogyris Westwood, I85I.

\section{Tribe ZESIINI Swinhoe stat. n.}

Zesiusinae Swinhoe, I9I I : I53. Type-genus: Zesius Hübner, I8I9.

Fore wing with II veins in female, but all I 2 veins may be present in male; veins 6 and 7 connate or stalked from apex of cell. Hind wing tailed or prominently toothed at vein 2, sometimes with shorter tails or teeth at veins $\mathrm{Ib}$ and 3 also. No secondary sexual characters, other than a visual brand of contrastingly coloured scales in Pseudalmenus. Eyes smooth. Antenna with rather gradual, cylindrical club; nudum extending down shaft; segments number about 45; shaft segments less than twice as long as wide. Palpi variable (see under sections). 
Male fore tarsus fused to a single segment ending in a down-curved point. Male genitalia with brachia and juxta. Early stages (based on Zesius and Jalmenus): larvae rather long and narrow, parallel-sided, dorsal line almost straight and bearing short conical teeth; pupa without (Zesius) or with (Jalmenus section) girdle. Oriental and Australian. Divided into 2 sections.

\section{Zesius section}

Fore wing with $\mathbf{2} 2$ veins in male. Hind wing with filamentous tails at veins $\mathrm{Ib}$ and 2 in male and at vein 3 also in female, that at vein 2 the longest. Palpi clothed appressed scales; third joint shorter than half second joint in male. Male genitalia (Text-fig. 38) with unusually large trough-like juxta. Single species confined to Peninsular India.

Included genus: Zesius Hübner, I8I9.

\section{Jalmenus section}

Fore wing with I I or I 2 veins in male. Hind wing tailed or toothed at vein 2 ; further more or less prominent teeth may be present at veins $\mathrm{Ib}, 3$ and 4 ; tail at vein 2 not filamentous, ciliate throughout on its lower side. Palpi with third joint very long (Jalmenus) to moderately short (Pseudalmenus); second joint clothed with some bristly scales (Jalmenus) or hairy (Pseudalmenus). Male genitalia (Text-figs 36,37 ) rather variable. Australian.

Included genera: Jalmenus Hübner, I8I8 (= Austromyrina C. \& R. Felder, I865); Protialmenus Waterhouse \& Lyell, I9I4; Pseudalmenus H. H. Druce, I9o2.

\section{Tribe AMBLYPODIINI Doherty stat. n.}

Amblypodiinae Doherty, I886 : г го. Type-genus: Amblypodia Horsfield, I829.

Fore wing with I 2 veins in males of Amblypodia and Iraota, otherwise I I veins; vein 7 from well before end cell; veins 5 and 6 connate or nearly so from apex of cell (Myrina, Iraota) or close together; Amblypodia female aberrant in having vein 7 ending on termen. Hind wing always tailed at vein $\mathrm{rb}$, but in Iraota there may be a longer tail at vein 2 and a further tail at vein 3 in female. Secondary sexual characters absent or ill-defined (see p. 405). Eyes smooth. Antennae stout, with gradual, cylindrical club and nudum extending down shaft; segments number about 35 or less in Myrina, but over 45 in other genera; shaft segments short, at most barely longer than wide. Palpi, very large in Myrina, clothed appressed scales; third joint short. Male fore tarsus fused to a single stubby-tipped segment; in Iraota and Amblypodia abnormal in being spined on outer as well as inner surface and sides. Male genitalia (Text-figs 43, 45) with brachia and juxta; uncus trifid in Myrina. Early stages: larvae variable, not regularly onisciform; waisted (Amblypodia) or highest and widest at segment 4 (Iraota) or tuberculate (Myrina); pupae suspended or reclining without a girdle in Amblypodia and Myrina. but with a weak girdle in Iraota. Oriental and African.

Included genera: Amblypodia Horsfield, I829 (= Horsfieldia Riley, I922); Iraota Moore, I88I; Myrina Fabricius, I807.

\section{Tribe GATAPAEGILMATINI trib. $\mathbf{n}$.}

Type-genus: Catapaecilma Butler, $\mathbf{1} 879$.

Fore wing with ro veins. Hind wing with at least three filamentous tails at veins $\mathrm{rb}, 2$ and 3 (a fourth tail at vein 4 in an unnamed Papuan species), that at vein 2 the longest. Under surface distinctive, with metallic silvery or nacreous markings; usual Lycaenine pattern distorted. Palpi hairy. Male fore tarsus fused to a single segment ending in a tapered, downcurved point. Secondary sexual characters, eyes, antennae, male genitalia and early stages - see under sections. Oriental. Divided into 2 sections. 


\section{Catapaecilma section}

Secondary sexual characters present; in the typical species these comprise a slightly swollen subbasal portion of vein I of the fore wing clothed with small specialized scales (Text-fig. I24) resembling the androconia of Deudorigini and the same scales clothe most of the other fore wing veins less densely; in two species the swollen portion of vein I is clothed with short hairy scales (Pl. 3, figs $\mathrm{I}_{5}, \mathrm{I} 6$ ) and the other veins do not bear androconia. Eyes hairy. Antenna with moderately abrupt cylindrical club; nudum divided into rectangular blocks by bands of scales commencing half-way down the club and continuing down the shaft; segments number about 30-34; shaft segments about three times as long as wide. Legs very hairy. Male genitalia (Text-fig. 44) with brachia and juxta. Early stages larva more or less onisciform, rather broad and depressed; pupa without girdle, terminal segment not horseshoe-shaped (Bell, I919 : 759760.)

Included genus: Catapaecilma Butler, I879.

\section{Acupicta section}

Hind wing with a 'false tornus' between veins $\mathrm{Ib}$ and 2, so that the true tornal lobe and tail at vein $\mathrm{rb}$ appear to project from the dorsum. No secondary sexual characters. Eyes smooth. Antenna with nudum entire, extending in an unbroken taper down the shaft. Male genitalia (Text-fig. 47) without juxta; valvae small. Early stages unknown.

Included genus: Acupicta gen. n. (p. 45I).

\section{Tribe OXYLIDINI trib. $\mathbf{n}$.}

Type-genus: Oxylides Hübner, I8I9.

Fore wing with ro veins. Hind wing tailed at veins $\mathrm{Ib}, 2$ and 3 , that at 2 the longest. No secondary sexual characters. Eyes smooth. Antenna with moderately abrupt cylindrical club; nudum confined to club; segments number about 25; shaft segments about 3-4 times as long as wide. Palpi clothed with appressed scales. Male fore tarsus fused to a single segment ending in a tapered, down-curved point. Male genitalia (Text-fig. 46) peculiar, with position and apparent function of valvae and juxta interchanged. Early stages unknown. African.

Included genera: Oxylides Hübner, I8I9; Syrmoptera Karsch, I895.

\section{Tribe HYPOTHEGLINI trib. $\mathbf{n}$.}

Type-genus: Hypothecla Semper, I890.

Fore wing with ro veins. Hind wing tailed at vein 2 (figs in Seitz inexplicably show a nonexistent tail at vein $\mathrm{rb}$ ), termen slightly stepped at vein 3, tornal lobe vestigial. No secondary sexual characters. Eyes smooth. Antenna with moderately abrupt cylindrical club; nudum confined to club; segments number about 35; shaft thin, segments about four times as long as wide. Palpi clothed with appressed scales; third joint shorter than half second joint. Male fore tarsus fused to a single segment ending in a tapered down-curved point. Male genitalia (Text-fig. 35) with brachia, rather small valvae and small U-shaped juxta. Early stages unknown. Papuan subregion and Wallacea (Philippines and Celebes).

Included genera: Hypothecla Semper, I89o; Hypochlorosis Röber, I892 (= Pseudonotis H. H. Druce, I894).

\section{Tribe LOXURINI Swinhoe stat. n.}

Loxurinae Swinhoe, I910 : II. Type-genus: Loxura Horsfield, I829.

Fore wing with Io or I I veins; vein 7 from before end cell. Hind wing with dominant tail at vein 2; additional tails may be present at veins $\mathrm{Ib}$ and 3 . Secondary sexual characters 
variable (see under sections); scent scales about the same size as ordinary scales; hair tufts for diffusing scent not present. Eyes smooth. Antenna with gradual to moderately gradual club and nudum extending in an unbroken taper down shaft; length, thickness and segmentation variable (see under sections). Palpi with third joint less than half second joint in males; second joint clothed appressed scales. Male fore tarsus fused to a stubby-tipped segment. Male genitalia rather variable, but brachia and juxta always present. Oriental. Divided into 3 sections.

\section{Loxura section}

Fore wing with veins 4,5 and 6 more or less equidistant at their origins. Hind wing produced and tailed at vein 2 only in Loxura and Yasoda, but rounded and with additional short tails at veins $\mathrm{Ib}$ and 3 in Eooxylides and Thamala. No secondary sexual characters in Loxura, but present in remaining genera; in Yasoda a long scent brand in a groove of hind wing; in Eooxylides a discal brand on upper surface of fore wing; in Thamala a brand on the under surface of the fore wing above the dorsum. Antennae variable; short and stout in Loxura and Yasoda with about 33-37 segments; short and rather slender in Eooxylides with about 36 segments; long in Thamala with about 47 segments. Palpi unusually large in Loxura and Yasoda. Male genitalia (Text-figs 50, 5I) characterized by broad, convex vinculum without a saccus; uncus incompletely divided, exdept in Thamala. Early stages: larvae waisted, smooth, feeding on monocotyledons; pupa suspended without a girdle (Morrell, 1956).

Included genera: Loxura Horsfield, I829; Yasoda Doherty, I889; Eooxylides Doherty, I889 (= Marshallia Doherty, I889; Indoxylides Doherty, I889); Thamala Moore, 1879 .

\section{Neomyrina section}

Fore wing with I I veins; vein 5 close to vein 6 and remote from vein 4 at its origin (as in Arhopala). Hind wing with very long, broad tail at vein 2 and short tails at veins $\mathbf{I b}$ and 3 . No secondary sexual characters. Antenna much shorter than half fore wing costa, yet with about 50 segments. Male genitalia (Text-fig. 49) with dorsal structures much lighter than in Loxura section; vinculum narrow and nearly straight with well-developed saccus. Early stages unknown.

\section{Included genus: Neomyrina Distant, I884.}

\section{Drina section}

Fore wing with I I veins; veins 4, 5 and 6 more or less equidistant. Hind wing tailed only at vein 2. Secondary sexual characters usually present in blue species, but absent in brown species; brands strongly resemble the aberrant brands found in the Uranothauma and Callictita sections of Polyommatini, comprising a fore wing discal patch of densely packed scent scales (Text-fig. 130) mixed with specialized hair scales or streaks of scent scales along and between the fore wing veins. Antenna with about 45 segments. Male genitalia (Text-fig. 48) chiefly distinguished by very small dorsal structures and very long, narrow vinculum. Early stages unknown.

Included genus: Drina de Nicéville, I890.

\section{Tribe HORAGINI Swinhoe}

Horaginae Swinhoe, I910 : Ir. Type-genus : Horaga Moore, I88I.

Fore wing with Io veins. Hind wing with filamentous tails at veins $\mathrm{rb}, 3$ and 2 , that at 2 the longest. Secondary sexual characters, when present, comprise small brands on the under surface of the fore wing. Eyes smooth. Antenna with moderately gradual, cylindrical club and nudum extending down shaft; segments number about 32-34; shaft segments about $\mathbf{1}_{4}^{1}-\mathbf{I}_{4}^{\frac{3}{4}}$ 
times as long as wide. Palpi with third joint less than half second joint, clothed appressed scales. Male fore tarsus fused to a single stubby-tipped segment. Male genitalia (Text-fig. 52) disproportionately large; uncus comprises curious flattened or hollowed blades, which may be short or very long; brachia asymmetrical; juxta small; valvae simple. Early stages: larvae abnormal, waisted and highest about segment 5, furnished with II (Horaga) to I5 (Rathinda) long, fleshy, dorsal and lateral horns; pupa fixed rigidly by cremaster without a girdle head uppermost.

Included genera: Horaga Moore, I88I ; Rathinda Moore, I88I (= Cupido Hübner, I8I9, praeocc.).

\section{Tribe GHERITRINI Swinhoe}

Cheritrinae Swinhoe, I9I0 : Ir. Type-genus: Cheritra Moore, I88I.

Fore wing with Io or II veins, the number sometimes varying in individuals of the same species. Hind wing tailed at veins $\mathrm{rb}$ and 2 (longest) with a short tail or tooth at vein 3 . Secondary sexual characters often present and may comprise large, apparently visual brands on fore wing disc or apparent scent brands bearing specialized scales about the same size as ordinary scales on the upper surface of the hindwing and under surface of the fore wing; in Cheritra a small erectile hair tuft is present on the upper surface of the hind wing. Eyes smooth. Antenna with moderately gradual, cylindrical club and nudum extending down shaft; segments number about 37 to 47 ; shaft segments not more than twice as long as wide. Male fore tarsus fused to a single stubby-tipped segment. Male genitalia abnormal, uncus and tegumen modified, brachia absent. Early stages (based on Cheritra and Drupadia) : larva shaped as in Horagini, but bearing only six dorsal triangular protuberances; pupa without girdle, head uppermost in Cheritra. Oriental and African. Divided into 2 sections.

\section{Cheritra section}

Palpi clothed with appressed scales. Male genitalia (Text-fig. 42) either with uncus and tegumen fused into widely separated, more or less triangular plates or with uncus lobes produced into digitate processes separated from lateral process of tegumen by a reduced lateral window; valvae bearing a costal arm hinged to inner face of uncus/tegumen complex; saccus, if developed, continued ventrad of vinculum; juxta absent. Oriental.

Included genera: Cheritra Moore, I88I; Ritra de Nicéville, I890; Cheritrella de Nicéville, I887; Ticherra de Nicéville, I887; Drupadia Moore, I884 (= Marmessus Auctt. nec Hübner, I8I9); Biduanda Distant, I884; Cowania gen. n. (p. 450).

\section{Dapidodigma section.}

Palpi clothed with bristly as well as appressed scales. Male genitalia (Text-fig. 63) with a large, hood-like structure above the penis hinged to valvae and tegumen; juxta present, resembling an inverted furca. African.

Included genus: Dapidodigma Karsch, I895.

\section{Tribe APHNAEINI Distant}

Aphnaria Distant, I884 : I96. Type-genus: Aphnaeus Hübner, I8I9.

Fore wing with IO, II or I 2 veins; veins 6 and 7 connate or stalked from cell apex. Hind wing rarely tailless, usually with a tail at vein $\mathrm{Ib}$ and often a shorter tail at vein 2 also. Under surface with the usual Lycaenine pattern often strongly modified. No secondary sexual characters. Eyes smooth, except in Aphnaeus and Paraphnaeus. Antennae very variable; club always cylindrical, but may be abrupt or gradual; nudum confined to club or continued down shaft. Palpi variable. Male fore tarsus fused to a single segment ending in a tapered, 
down-curved point, except in Aphnaeus (in which it is almost stubby-tipped). Tarsal claws with a prominent endodont. Tibiae sometimes bear short, chitinous projections at tarsal joint. Male genitalia with juxta and brachia present. Early stages: larvae rather long and parallel-sided, with permanently raised basal rings sheathing the extrusible tubercles of the IIth segment; pupae very rarely girdled, but usually enclosed in some form of shelter or reclining. African and Oriental, with a slight extension into the Palaearctic Region. Divided into 2 sections.

\section{Aphnaeus section}

Under surface nearly always bearing metallic silvery, golden or nacreous spots or stripes on fore wing and often on hind wing also; some species bear superficial resemblance to 'Coppers'. Palpi normally developed, usually clothed with appressed scales but bearing long bristly scales in Erikssonia. Proboscis of average size. Male genitalia (Text-fig. 54) with normally articulating brachia; valvae united dorsally by a semi-membranous band above the penis.

Included genera: Aphnaeus Hübner, I8I9 (= Aphnaemorpha de Nicéville, I89o); Paraphnaeus Thierry-Mieg, I904; Apharitis Riley, I925; Cigaritis Donzel, I847 (= Zerythis Lucas, I849); Spindasis Wallengren, I857; Lipaphnaeus Aurivillius, I9I6; Chloroselas Butler, I886; Zeritis Boidsuval, I836; Desmolycaena Trimen, I898; Axiocerces Hübner, I8I9 (= Chrysorychia Wallengren, I857); Phasis Hübner, I8I9 (= Pseudocapys Murray, I935); Aloeides Hübner, I8I9; Poecilmitis Butler, I899; Chrysoritis Butler, I898; Crudaria Wallengren, I875; Erikssonia Trimen, I89I; Nais Swainson, I833, invalid, praeocc.

\section{Pseudaletis section}

Fore wing rather large in comparison with hind wing. White or orange species, with the markings on the under surface without metallic ornamentation and tending to fade out. Palpi minute, much less than half length of head, clothed with appressed scales. Proboscis functional, but very short. Male genitalia (Text-fig. 4I) with brachia reduced to short pointed processes inflexibly fused to lateral processes of tegumen; lateral window lacking. Female bears prominent tuft of specialized scales on abdomen.

Included genus: Pseudaletis H. H. Druce, I888.

\section{Tribe IOLAINI Riley}

Iolaini Riley, I956 : 285. Type-genus: Iolaus Hübner, I8r9.

Fore wing with Io, I I or, rarely in male only, I2 veins. Hind wing always tailed at veins $\mathrm{Ib}$ and 2 and occasionally at vein 3 also; tail at vein $\mathrm{Ib}$ dominant. Secondary sexual characters (see under sections) usually present. Eyes smooth, except in Trichiolaus. Antenna with cylindrical club; nudum and segmentation variable (see under sections). Palpi clothed with appressed scales; in male third joint less than half length of second joint, except in Pseudiolaus. Male fore tarsus and male genitalia variable (see under sections). Early stages: larvae waisted and shouldered about segments 5 and 6, feeding always on Loranthaceae; pupae attached by cremaster without girdle, usually more or less horizontal or head downwards, less commonly standing out rigidly at an angle from the support with head uppermost. Divided into 3 sections.

\section{Iolaus section}

Secondary sexual characters most commonly comprise a scent brand (Pl. 2, figs Io-I2) below the costa on the upper surface of the hind wing associated with a hair brush on the fore wing dorsum, but a variety of other types occur; in Creon (Pl. 2, figs 7-9) there is a second, much smaller tuft on the fore wing dorsum composed of very large boat-shaped scales; in Iolaus the scent brand is on the under surface of the fore wing lying beneath the hair brush; in Dacalana 
and Thrix (of which Virgarina is a subjective synonym) there is a scent brand beneath an overlying hair brush on the fore wing disc, and in Manto (of which Pseudomyrina is a subjective synonym) a similar arrangement is found near the costal margin of the hind wing; in Purlisa there are scent brands on either side of the abdomen associated with hair fringes on the hind wing; in a number of species there are brands, possibly purely visual, on the fore wing disc. Antenna with nudum continued down shaft; segments about twice as long as wide or a little less. Male fore tarsus segmented and clawed in Sukidion and in the type-species of Pratapa, otherwise fused to a single stubby-tipped segment. Male genitalia (Text-figs 55-57), though showing an unusual degree of interspecific difference, are of more or less commonplace pattern, except in Philiolaus which has a pseudotergum; brachia present usually, but absent or vestigial in Etesiolaus, Argiolaus and some Epamera species; juxta always present. African and Oriental; African genera are listed in first paragraph and Oriental genera in the second.

Included genera: Iolaus Hübner, I8I9; Stugeta H. H. Druce, I89I; Pseudiolaus Riley, I928; Trichiolaus Aurivillius, I898; Tanuetheira H. H. Druce, I89I; Argiolaus H. H. Druce, I89I; Iolaphilus Stempffer \& Bennett, I958; Philiolaus Stempffer \& Bennett, I958; Aphniolaus H. H. Druce, I902; Epamera H. H. Druce, I89I; Etesiolaus Stempffer \& Bennett, I959.

Pratapa Moore, I88I; Tajuria Moore, I88I; Dacalana Moore, I884; Arrhenothrix de Nicéville, I89o; Maneca de Nicéville, I89o; Creon de Nicéville, I896; Bullis de Nicéville, I897; Sukidion H. H. Druce, I89I; Purlisa Distant, I88I; Jacoona Distant, I884; Neocheritra Distant, I885; Manto de Nicéville, I895; Pseudomyrina H. H. Druce, I895; Mantoides H. H. Druce, I896; Thrix Doherty, I89I; Virgarina H. H. Druce, I895; Charana de Nicéville, I89o; Suasa de Nicéville, I89o; Cophanta Moore, I884, Ops de Nicéville, I895, and Creusa de Nicéville, I896, invalid, praeocc.

\section{Britomartis section}

Single species superficially resembling Iolaus section in most characters. Secondary sexual characters comprise a large patch of loosely attached, (?) scent scales on fore wing disc. Antenna Hypolycaena-like, with short, abrupt club and nudum confined thereto; segments number about 32; shaft segments about three times as long as wide. Male fore tarsus as in Iolaus section. Male genitalia (Text-fig. 59) abnormal; armature small; valvae fused to vinculum; additional chitinous structures of a complicated nature within seventh and eighth sternites. Oriental.

Included genus: Britomartis de Nicéville, I895.

\section{Hemiolaus section}

Secondary sexual characters comprise a scent brand beneath an overlying hair brush on the upper surface of the hind wing. Antenna like Britomartis. Palpi with third joint only slightly less than half the second joint. Male fore tarsus ending in a tapered, down-curved point. Male genitalia (Text-fig. 58) with abnormal juxta suggesting a transition to Hypolycaena. African, most strongly represented in Madagascar.

Included genus: Hemiolaus Aurivillius, I923.

\section{Tribe REMELANINI trib. $\mathbf{n}$.}

Type-genus: Remelana Moore, I 884 .

Superficially resembling Iolaus section of Iolaini in wing shape, pattern, secondary sexual characters, antennae and male fore tarsus. Palpi with third joint as long as or longer than half second joint (as in Hypolycaenini), clothed with appressed scales. Eyes hairy or smooth. Male genitalia (Text-figs 6r-63) much closer to pattern of Hypolycaenini and Deudorigini than 
to pattern of Iolaini; juxta absent or vestigial; penis long and thin; valvae ventrally conjoined or separate. Early stages (only known for Ancema blanka de Nicéville, comb. n.) resemble those of Hypolycaenini rather than Iolaini, except that food plant belongs to Loranthaceae; larva more or less onisciform; pupa girdled. Oriental.

Included genera: Remelana Moore, I884; Ancema nom. n. pro Camena Hewitson, I865, praeocc. by Camena Martens, I860; Pseudotajuria gen. n. (p. 45I).

\section{Tribe HYPOLYGAENINI Swinhoe stat. $\mathbf{n}$.}

Hypolycaeninae Swinhoe, I910 : II. Type-genus: Hypolycaena C. \& R. Felder, I862.

Fore wing with ro veins. Hind wing tailed at vein $\mathrm{rb}$, except in Gonatomyrina which has tornus produced, and also at vein 2, except in Leptomyrina; tail at vein rb dominant and may be very long and ciliate on both sides. Secondary sexual characters not often present; in Tatura there is a narrow pouch lined with small scales on vein $\mathbf{I}$ of the fore wing overlaid by an erectile hair tuft and there is a further scent brand at the base of space 2; in 'Hypolycaena' liara H. H. Druce and ' $H$.' naara Hewitson there is a small round brand at the end of the fore wing cell bearing undersized, presumed scent scales (Pl. 3, fig. 13); in the species of the ' $H$ '. phorbas (Fabricius) group there is a larger but more obscure brand on the fore wing disc which may be part scent and part visual; obscure, opaque visual brands occur in a very few other species. Eyes hairy. Antenna with rather abrupt club, cylindrical except in the typical species of Chliaria; nudum usually confined to club, but sometimes continuing down shaft in a series of detached patches; segments number less than 40 , frequently less than 30 ; shaft segments at least three times as long as wide. Palpi with third joint at least half as long as second joint, and usually longer; second joint clothed appressed scales. Male fore tarsus fused to a single segment ending in a tapered, down-curved point. Male genitalia (Text-fig. 6o) with a strong internal lateral ridge, as in Avhopala section of Arhopalini; no juxta; valvae usually rather small and simple and may be ventrally conjoined for up to half their length. Early stages: larvae more or less onisciform; pupae girdled, except sometimes when sheltered or reclining. African and Oriental.

Included genera: Hypolycaena C. \& R. Felder, I862; Chliaria Moore, I884; Zeltus de Nicéville, I890; Leptomyrina Butler, I898; Gonatomyrina Aurivillius, I924; Tatura Butler, I887 (subject to ruling by the International Commission on Zoological Nomenclature).

\section{Tribe DEUDORIGINI Doherty}

Deudoriginae Doherty, I886 : I Iо. Type-genus: Deudorix Hewitson, I863.

Fore wing with I I veins, except in Sithon with Io; veins II and I2 touch or briefly anastomose in three genera. Hind wing tailed at vein 2, except in Capys section, and sometimes at vein 3 also; never tailed at vein rb. Secondary sexual characters most often comprise a scent brand above the hind wing cell associated with a hair brush on the fore wing dorsum (much as in Iolaini); scent scales (Pl. I, fig. 2 and Text-fig. I26) much smaller than ordinary scales. Additional scent brands may occur on fore wing or hind wing or even on the abdomen (Pilodeudorix) with associated hair brush on the hind wing. Eyes hairy. Antenna with cylindrical club, with nudum confined thereto or extending only a short distance down shaft; segmentation variable; segments number from about 44 (Avtipe) to under 30 ; shaft segments from about twice to nearly four times as long as wide. Palpi clothed with appressed scales, except in Pamela. Male fore tarsus fused to a single segment ending in a tapered down-curved point. Male genitalia (Text-fig. 65) 'greyhound-shaped', with rather heavy dorsal structures, inclined vinculum and rather small valvae ventrally conjoined for part of their length; brachia present; no juxta; penis usually long and thin. Early stages: larva more or less onisciform; pupa 
girdled. African and Oriental, extending weakly into Palaearctic and Australian Regions. Divided into two sections.

\section{Deudorix section}

Fore wing with veins 6 and 7 separate, though sometimes very narrowly so, at their origins. Hind wing always tailed.

Included genera: Deudorix Hewitson, I863; Artipe Boisduval, I870 (= Lehera Moore, I884); Virachola Moore, I88I ; Hypomyrina H. H. Druce, I89I ; Actis Karsch, I895; Kopelates H. H. Druce, I89I; Hypokopelates H. H. Druce, I89I; Pilodeudorix H. H. Druce, I89I; Diopetes Karsch, I895; Sithon Hübner, I8I9; Sinthusa Moore, I884; Pseudochliaria Tytler, I9I5; Araotes Doherty, I889, Bindahara Moore, I88I; Rapala Moore, I88I; Hysudra Moore, I882; Nadisepa Moore, I882; Baspa Moore, I882; Bidaspa Moore, I882; Stilbon Rothchild \& Jordan, I905; Vadebra Moore, I884, invalid, praeocc.

\section{Capys section}

Fore wing with veins 6 and 7 stalked or, sometimes in Capys, connate from cell apex. Hind wing tailless but produced at tornus.

Included genera: Capys Hewitson, I865 (= Scoptes Hübner, I8I9, subject to ruling by the International Commission on Zoological Nomenclature); Pamela Hemming, I935 (= Listeria de Nicéville, I894, praeocc.).

\section{Tribe TOMARINI trib. $\mathbf{n}$.}

[Thestoridi Tutt, I907:86, 87. Tomares Rambur, I840 was formerly incorrectly known as Thestor Hübner, [1819] because of an overlooked type-species designation for the latter genus].

Type-genus: Tomares Rambur, 1840.

Fore wing with I I veins; veins 6 and 7 stalked. Hind wing tailless and tornal lobe vestigial. Secondary sexual characters comprise small scent brands on fore wing at cell apex and at base of veins 3 and 4 ; scent scales (Text-fig. I3I) resemble those of Deudorigini. Eyes and palpi densely hairy. Antenna with well-formed club to which the nudum is confined; segments number about 32; shaft moderately stout and segments barely longer than wide. Male fore tarsus fused to a single segment ending in a tapered, down-curved point. Legs stout and hairy, with tibiae bearing large chitinous projections at tarsal joint. Male genitalia (Text-fig. 64) resemble those of Deudorigini. Early stages: larva onisciform; pupa girdled. Palaearctic.

Included genus: Tomares Hübner, I840.

\section{Tribe EUMAEINI Doubleday}

Eumaeidae Doubleday, I847 : 20. Type-genus: Eumaeus Hübner, I8I9.

Fore wing with ro veins; in other respects venation variable. Hind wing seldom tailless, usually tailed or toothed at vein 2 and often with a shorter tail or tooth at vein 3; never tailed or toothed at vein $\mathrm{Ib}$. On under surface the normal Lycaenine pattern may be unrecognizable in some Neotropical genera. Secondary sexual characters usually present (see under sections). Eyes hairy (but sparsely so in some Neotropical genera, especially Arawacus). Antennae extremely variable; club usually cylindrical, but flattened in Strymon and a few related genera; nudum confined to club in Holarctic genera, but often continued down shaft in an unbroken taper or in a series of detached patches in Neotropical genera; segmentation very variable, ranging from about 45 to 23. Palpi variable; very small in Brangas and some Neotropical 
species; scaling may be smooth, bristly or hairy; third joint short. Proboscis often bearing short sensory hairs on its inner surface in Neotropical genera. Male fore tarsus segmented and clawed in Theclopsis, otherwise fused to a single stubby-tipped segment. Male genitalia (Text-figs 66, 68) often furnished with brush organs in Neotropical genera, otherwise remarkably homogeneous and broadly similar to those of Deudorigini and Tomarini. Early stages (very little known for Neotropical genera) : larvae more or less onisciform; pupae girdled. Holarctic and Neotropical. An enormous tribe requiring exhaustive investigation before it can be satisfactorily subdivided using characters other than the male genitalia. Meantime provisionally divided into one large and one very small section, mainly on the basis of differences in the male fore tarsus.

\section{Eumaeus section}

Secondary sexual characters most commonly comprise a brand, which may be scent or visual or a combination of both types, at apex of fore wing cell; presumed scent scales (Pl. I, figs 4, 5 and Text-figs I 22, I23) smaller than ordinary scales; many other types of character may occur on fore wing or hind wing (see p. 388); hair brushes do not occur on fore wing dorsum (as in Deudorigini), but in Heterosmaitia there is a small erectile hair tuft on the hind wing and in Allosmaitia there is a tuft of curious, very long and basally swollen scales in the same place. Male fore tarsus more or less cylindrical and normally spined beneath. Genera are listed in two groups: first, those in which brush organs are not known to occur; secondly, those with brush organs (Ipidecla to Eumaeus).

Included genera: Callophrys Billberg, I820 (= Lycus Hübner, I8I9, praeocc.; Licus Hübner, I823); Mitoura Scudder, I872; Incisalia Scudder, I872; Erora Scudder, I872; Callipsyche Scudder, I876; Ahlbergia Bryk, I946 (= Ginzia Okano, I947; Satsuma Murray, I875, praeocc.); Fixsenia Tutt, I907; Nordmannia Tutt, I907; Strymonidia Tutt, I908; Satyrium Scudder, I876; Chattendenia Tutt, I908 (=Edwardsia Tutt, I907, praeocc.); Thecliolia Strand, I9Io (= Felderia Tutt, I907, praeocc.); Pseudothecla Strand, I9Io (= Erschoffia Tutt, I907, praeocc.); Tuttiola Strand, I9Io (= Klugia Tutt, I907, praeocc.); Superflua Strand, I9Io (= Kollaria Tutt, I907, praeocc.); Neolycaena de Nicéville, I890; Sandia Clench \& Ehrlich, r960; Xamia Clench, I96r; Cyanophrys Clench, I96r; Chlorostrymon Clench, I96r; Electrostrymon Clench, I96r; Euristrymon Clench, I96r; Hypostrymon Clench, I96r ; Ministrymon Clench, I96r ; Phaeostrymon Clench, I96r; Strymon Hübner, I8I8 (= Callipareus Scudder, I872; Uranotes Scudder, I876); Callicista Grote, I873; Calycopis Scudder, I876; Dolymorpha Holland, I93I; Eupsyche Scudder, I876; Panthiades Hübner, I8I9; Parrhasius Hübner, I8I8; Tmolus Hübner, I8I9; Cycnus Hübner, I8I9; Oenomaus Hübner, I8I9; Olynthus Hübner, I8I9; Thestius Hübner, I8I9; Polyniphes Kaye, I904; Iaspis Kaye, I904; Siderus Kaye, I904; Arawacus Kaye, I904; Theclopsis Godman \& Salvin, I887; Nesiostrymon Clench, I964; Allosmaitia Clench, I964; Calystryma Field, I967; Symbiopsis Nicolay, I971; Argus Gerhard, I850, invalid, praeocc.; Bakeria Tutt, I907, invalid, praeocc.

Ipidecla Dyar, I9I6; Theritas Hübner, I818; Mithras Hübner, I8I9; Atlides Hübner, I8I9; Evenus Hübner, I8I9 (= Endymion Swainson, I83I); Chalybs Hübner, I8I9; Thereus Hübner, I8I9; Arcas Swainson, I832; Lamprospilus Geyer, I832; Pseudolycaena Wallengren, I858; Molus Hübner, I8I9; Paiwarria Kaye, I904; Rekoa Kaye, I904; Macusia Kaye, I904; Heterosmaitia Clench, I964; Brangas Hübner, I8I9; Theorema Hewitson, I865; Eumaeus Hübner, I8I9 (= Eumenia Godart. I824; Eumaea Geyer, I834); Eucharia Boisduval, I870, invalid, praeocc. 


\section{Trichonis section}

Fore wing venation commonplace in Trichonis, but extremely abnormal in Micandra (Textfig. 67). Hind wing tailless with rounded tornus, except in female of Micandra, which is tailed and lobed. Secondary sexual characters unlike those found in Eumaeus section, presumed scent scales not smaller than ordinary scales; in Trichonis there are large brands on under surface of fore wing and upper surface of hind wing bearing large specialized scales (Text-fig. I28); in Micandra there is a large brand on fore wing bearing two types of specialized scales (Text-fig. I27). Male fore tarsus short, stout, centrally swollen and spined only at tip. Male genitalia without brush organs.

Included genera: Trichonis Hewitson, I865; Micandra Staudinger, I888.

\section{Subfamily LYGAENINAE Leach}

Lycaenida Leach, I8I5 : I29. Type-genus: Lycaena Fabricius, I807.

Fore wing with I I veins; veins 6 and 7 usually narrowly separated, but sometimes connate or with a short stalk. Hind wing tailed at vein 2 or tailless, tornus lobed or rounded. No secondary sexual characters. Eyes smooth. Antennae with well-formed club, more or less flattened beneath, to which the nudum is confined; shaft segments at least three times as long as wide. Palpi clothed with hairy or bristly scales. Proboscis with smooth shaft. Male fore tarsus fused to a single segment ending in a sharp or rounded point. Male genitalia (Textfig. 69) with tegumen much reduced and uncus comprising long, digitate lobes; brachia, saccus and juxta strongly developed; penis generally long and thin, widely open on its dorsal surface for the reception of the ductus, supra- and subzonal portions subequal, in general recalling the Thecline penis. Early stages: egg usually a flattened dome with large indentations; larva onisciform; pupa girdled. Mainly Holarctic, but weakly represented in all other Regions (see footnote on p. 464). Divided into two sections.

\section{Lycaena section}

True 'Coppers' with Polyommatine-like markings on under surface. Male fore tarsus ending in a sharp, tapered, down-curved point.

Included genera: Lycaena Fabricius, I807 (= Migonitis Sodovsky, I837; Lycia Sodovsky, I837; Rumicia Tutt, I906); Heodes Dalman, I8I6 (= Chysoptera Zincken, I8I7); Loweia Tutt, I906 (= Palaeoloweia Verity, I943); Hyrcanana BethuneBaker, I9I4; Helleia Verity, I943; Palaeochrysophanus Verity, I943; Sarthusia Verity, I943; Phoenicurusia Verity, I943; Thersamonia Verity, I9I9; Tharsalea Scudder, I876; Gaeides Scudder, I876; Chalceria Scudder, I876; Epidemia Scudder, I876; Disparia Verity, I943, invalid, praeocc.

\section{Heliophorus section}

With Thecline-like markings beneath. Male fore tarsus ending in a blunt, rounded point.

Included genera: Heliophorus Geyer, I832 (= Ilerda Doubleday, I847); Iophanus Draudt, I920.

\section{Subfamily POLYOMMATINAE Swainson}

Polyommatidae Swainson, I827 : 187. Type-genus: Polyommatus Latreille, I804.

Fore wing with I I veins, except in Neuvellipes and Triclema (Lycaenesthini) and Cupidopsis (Polyommatini); veins 6 and 7 separate at their origins, sometimes very narrowly so. Hind wing tornus rounded or with a vestigial lobe in a few genera; tailless or with a filamentous tail at vein 2 only. Eyes and palpi very variable. Antenna with well-defined club more or less 
flattened or hollowed beneath, except in Niphanda females; shaft segments not less than three times as long as wide. Proboscis with shaft smooth, except in Callictita (Polyommatini) which bears some short, fine sensory hairs on its inner surface; terminal sensory area usually very weakly developed. Male fore tarsus fused to a single segment and, except in Candalidini, ending in a tapered, down-curved point. Mid and hind tibiae with terminal spurs. Male genitalia moderately variable (see under sections). Early stages: egg flattened or depressed, usually widest in the middle and not wider at base than at top; larva onisciform; pupa girdled or reclining.

\section{Tribe LYGAENESTHINI Toxopeus stat. $\mathbf{n}$.}

Lycaenesthinae Toxopeus, 1929: 218. Type-genus: Lycaenesthes Moore, I866.

Fore wing with veins II and I2 free or touching or briefly anastomosed. Hind wing tailless, but with cilia almost always elongated into tail-like tufts at veins $\mathrm{rb}, 2$ and 3 . Secondary sexual characters absent, except for the presence of long plume scales (p. 407), believed not to be scent scales. Eyes usually hairy, but smooth in a few species of Cupidesthes. Antenna with club almost cylindrical in a few species; nudum confined to club. Male genitalia (Text-fig. 70) with uncus divided into separated lobes; brachia, juxta and saccus present; penis widely open on dorsal surface for reception of ductus, coecum developed, sub- and suprazonal portions subequal. African, with rather weak representation in Oriental Region.

Included genera: Lycaenesthes Moore, I866; Anthene Doubleday, I847; Cupidesthes Aurivillius, I895; Neurypexina Bethune-Baker, I9Io; Neurellipes BethuneBaker, I9Io; Monile Ungemach, I932; Triclema Karsch, I893.

\section{Tribe GANDALIDINI trib. $\mathbf{n}$.}

Type-genus: Candalides Hübner, I8I9.

Fore wing with veins II and I 2 free. Hind wing tailless. On under surface there is a tendency for markings to become obsolete in a few species. Male secondary sexual characters comprise only dagger scales ( $\mathrm{Pl}$. 4, figs 23,24 and Text-fig. 156 ), which may be concentrated into a 'trident mark' along the bases of veins 2, 3 and 4 and/or may spread over the wings in alternate rows with ordinary scales. Eyes smooth. Antenna with nudum interrupted by bands of scales to tip of club or nearly so. Male fore tarsus more or less stubby-tipped in majority of species, but occasionally tapered to a blunt, rounded point. Male genitalia (Text-figs 72,73 ) flattened in profile; lobes of uncus well-separated; brachia distinctive in having a short bifurcation shortly before the tip, but the branch is long in one species of Evina; juxta present, small or large, and asymmetrical in the margarita species group of 'Holochila'; saccus weakly developed or absent; penis widely open on the dorsal surface for reception of ductus, coecum barely developed. Early stages: larva onisciform; pupa distinctive with edges of abdomen flattened and upturned and with a single or double projection at head.

Included genera: Candalides Hübner, I8I9; Erina Swainson, I833 (= Holochila C. Felder, I862); Cyprotides Tite, I963; Microscena Tite, I963; Adaluma Tindale, I922; Nesolycaena Waterhouse \& Lyell, I905; Zetona Waterhouse, I938; Holochila sensu auctt. nec C. Felder ${ }^{8}$.

\section{Tribe NIPHANDINI trib. $\mathbf{n}$.}

Type-genus: Niphanda Moore, 1875 .

Fore wing with veins II and I2 free. Hind wing tailless. Secondary sexual characters comprise 'hieroglyphically-marked' scales (P1. 4, figs 20-22 and Text-fig. I6o) arranged in

\footnotetext{
8It is understood that Couchman is renaming this genus.
} 
alternate rows with ordinary scales. Eyes hairy. Antennae exhibit strong sexual dimorphism; club moderately abrupt in male, more or less flattened beneath and with nudum confined thereto; in female club gradually incrassate, cylindrical (but flattened at tip in N. fusca (Bremer $\&$ Grey)) and with nudum extending down shaft almost to base. Palpi clothed with appressed scales. Male genitalia (Text-fig. 7I) with dorsal structures rather Thecline-like, only slightly excavate between lobes of uncus; penis widely open on dorsal surface for reception of ductus; valvae simple; juxta a short, broad Y; no saccus. Early stages (only for $N$. fusca) : larva slightly abnormal, increasing in girth gradually as far as tenth segment, aphytophagous. Oriental and Eastern Palaearctic.

Included genus: Niphanda Moore, I875.

\section{Tribe POLYOMMATINI Swainson}

Fore wing with veins II and I 2 variable, may be free, touch or anastomose; in a few species vein II may arise from vein Io; in Jamides section an additional vein linking veins I I and I 2 occurs. Hind wing tailed or tailless. Secondary sexual characters comprise various types of specialized scales, of which battledore androconia (Pl. 5), arranged in alternate rows with ordinary scales, are much the most frequent; in Uranothauma and Callictita sections compact patches or streaks of specialized hair and short plume scales occur. Eyes variable. Antennae with nudum confined to club. Palpi variable. Male genitalia with undivided uncus in Everes section, otherwise divided (narrowly and imperfectly in Azanus section) into separated lobes: brachia usually present, but never bifurcate as in Candalidini; juxta usually furca-like, but occasionally reduced to a small plate or otherwise modified; saccus not or only very slightly developed, except in Una and Petrelaea sections; penis very variable, giving better section characters than other components of genitalia, frequently ornamented with complex cornuti or scobinate patches. Cosmopolitan.

I have to admit complete failure in my efforts to find a satisfactory basis for subdividing this very large tribe into a few major natural groups. I have therefore fallen back on naming no less than thirty 'sections', many of them of no more than subsection or even generic worth. Where one section appears to be particularly close to another I have said so in the diagnoses which follow. Where, as in the majority of cases, I am uncertain where a section's affinities lie I have made no comment.

\section{Cupidopsis section}

Fore wing with only ro veins. Hind wing tailed or tailless.' No secondary sexual characters. Male genitalia (Text-fig. 74): penis with ductus entering on dorsal surface, coecum developed; saccus weakly developed. African.

Included genus: Cupidopsis Karsch, I895.

\section{Una section}

Fore wing with II veins, as in all succeeding sections; veins II and I2 anastomosed, as far as costa in Una. Hind wing tailless, with cilia elongate at tornus. No secondary sexual characters. Eyes and palpi intensely hairy. Male genitalia (Text-fig. 75) typically with brachia atrophied, but present in Orthomiella; penis long, with ductus entering cephalad or ventro-cephalad, sub- and suprazonal portions subequal; saccus moderately developed. Oriental. Appears to be fairly close to the next section.

Included genera: Una de Nicéville, I89o; Orthomiella de Nicéville, I89o. 


\section{Petrelaea section}

Fore wing with veins I I and I 2 anastomosed. Hind wing tailless. Secondary sexual characters comprise paddle scales in Petrelaea (Text-fig. I48) or rather rectangular battledore scales with concave bases in Pseudonacaduba (Text-fig. 152). Eyes and palpi hairy. Male genitalia (Text-figs 76,78$)$ : penis long, ductus entering on ventral surface, sub- and suprazonal portions subequal; saccus developed, strongly so in Pseudonacaduba. Oriental and African.

Included genera: Petrelaea Toxopeus, I929; Pseudonacaduba Stempffer, I943.

\section{Nacaduba section}

Fore wing with veins I I and I 2 anastomosed, in Neolucia as far as costa. Hind wing tailed or tailless. Battledore androconia usually present, but in Erysichton lineata (Murray) very long paddle scales occur. Eyes and palpi hairy. Male genitalia (Text-figs 77, 79) with brachia present in all genera except Erysichton; penis with ductus entering on dorsal surface, a short coecum usually present, suprazonal portion short and usually furnished with a single or double Chapman's process sometimes of great length. Oriental and Australian.

Included genera: Nacaduba Moore, I88I; Prosotas H. H. Druce, I89I; Ionolyce Toxopeus, I929; Catopyrops Toxopeus, I929; Erysichton Fruhstorfer, I916; Paraduba Bethune-Baker, I906; Neolucia Waterhouse \& Turner, I905; Hypojamides Riley, I929 (included provisionally; female only seen).

\section{Theclinesthes : ection}

Superficially similar to Nacaduba section. Battledore scales (Text-fig. I59) commonplace, but may be enlarged basally. Male genitalia (Text-figs 92, 98) with broad to fairly broad vinculum; penis basally dilated and apically tapered with ductus entering cephalad. Papuan and Australian, appearing to form a link between Nacaduba and Upolampes sections, and also fairly closely related to Danis and Callictita sections.

Included genera: Theclinesthes Röber, I891; Thaumaina Bethune-Baker, I908; Utica Hewitson, I865, invalid, praeocc.

\section{Upolampes section}

Fore wing with veins Io, II and I 2 abnormal; veins II and I 2 anastomosed or touching; in some species vein ro arises from vein II, in others vein I I arises from vein Io; in Pistoria vein I I is reduced to a short cross-vein between veins io and I2. Hind wing tailed or tailless. Pattern on under surface somewhat abnormal; usual markings often conjoined into black bars or bands, including sub-basal bands on one or both wings. Battledore scales (Text-fig. I5I) resembling those found in Pseudonacaduba (Petrelaea section) occur only in Upolampes. Male genitalia (Text-figs 8o-88) with brachia absent or vestigial; penis short and stout, with ductus entering cephalad, suprazonal portion short; valvae and juxta variable, both simple in Upolampes and Discolampa, but in other genera combining with anellus to form a complicated structure from which it is impossible to detach the penis without tearing the structure apart. Oriental.

Included genera: Upolampes Bethune-Baker, I908; Caleta Fruhstorfer, I922; Pycnophallium Toxopeus, I929; Discolampa Toxopeus, I929 (= Ethion Shirôzu \& Saigusa, I962); Pistoria Hemming, I964 (= Mambara Bethune-Baker, I908, praeocc.).

\section{Danis section}

Fore wing with veins I I and I 2 touching briefly. Hind wing tailed or tailless. Pattern of under surface always abnormal, usually with fuscous costal and terminal borders often ornamented with metallic silvery green markings and with all other markings obsolete; in one 
aberrant species, Psychonotis purpurea (H. H. Druce) comb. n., the under surface is yellowish buff with obscure reddish brown markings. Battledore scales, absent in Epimastidia, resemble those of Jamides in Danis (Text-fig. 158) but in Psychonotis are commonplace (Text-fig. 154). Eyes hairy. Palpi hairy or bristly. Male genitalia (Text-fig. 94): penis with ductus entering cephalad, suprazonal portion rather short; in Psychonotis (Text-fig. 93) an apparently unique feature occurs: the upper part of the diaphragma bears a sclerotized band rather weakly connected to the apices of the furca-shaped juxta and to the lateral processes of the tegumen, so that the band and juxta form a ring surrounding, but well separated from, the penis. Papuan, extending weakly across Wallace's Line and into Australia.

Included genera: Danis Fabricius, I807 (= Thysonotis Hübner, I8I9; Hadothera Billberg, I820; Damis Boisduval, I832); Psychonotis Toxopeus, I930; Epimastidia H. H. Druce, I89I.

\section{Jamides section}

Fore wing with the usual I I veins and an additional short cross-vein linking veins II and I 2 , which are otherwise completely free of one another. Hind wing tailled or toothed. On the under surface the usual Lycaenine pattern is arranged in stripes, but in a few species of Pepliphorus the discal and basal markings are faded out and the pattern approaches that of Danis, with silvery green ornamentation sometimes present. In most species rather large battledore scales, with ribs converging as in a fan, are present, but in Jamides cyta (Boisduval) only paddle scales occur. Eyes hairy. Scaling of palpi variable. Male genitalia (Text-fig. 95): penis with ductus entering on dorsal surface, coecum quite well-developed, suprazonal portion short. Oriental, extending into Australian Region.

Included genera: Jamides Hübner, I8I9; Pepliphorus Hübner, I8I9 (= Peplodyta Toxopeus, I929).

\section{Catochrysops section}

Fore wing with veins II and I 2 touching briefly in Catochrysops but free in Rysops. Hind wing tailed. Battledore scales (Text-figs I39, I40) rectangular, with the pedicel tapered to a point where it is attached to the scale and consequently very easily broken off. Eyes and palpi hairy. Male genitalia (Text-figs 96, 97) with brachia present in Catochrysops, absent in Rysops; penis with ductus entering cephalad, suprazonal portion short. Oriental, with single relict species in Madagascar.

Included genera: Catochrysops, Boisduval, I832; Rysops gen. n. (p. 452).

\section{Lampides section}

Fore wing with veins 6 and 7 free. Hind wing tailed. Androconia (Text-fig. I6r) unique; in addition long plume scales are sufficiently dense to give a shadow on the wings. Eyes and palpi hairy. Male genitalia (Text-fig. IоI): penis with ductus entering on dorsal surface, coecum barely developed, suprazonal portion short. Old World and Australia.

Included genus: Lampides Hübner, I8I9 (= Cosmolyce Toxopeus, I927; Lampidella Hemming, I933).

\section{Callictita section}

Fore wing with veins I I and I 2 briefly anastomosed. Hind wing tailed and with a vestigial tornal lobe. Secondary sexual characters aberrant for tribe, comprising a large discal patch on fore wing densely clothed with a mixture of specialized hair scales and short plume scales. Eyes and palpi hairy. Proboscis bears inconspicuous, short sensory hairs on its inner surfaceMale genitalia (Text-fig. 89) abnormal, particularly in respect of penis which bears a trough. like 'footstalk' and has the suprazonal portion long and tapered. Papuan. Bears a close 
superficial resemblance to the species of the next section, especially to Uranothauma nubifer (Trimen), and may well be related thereto despite marked differences in male genitalia.

Included genus: Callictita Bethune-Baker, I908.

\section{Uranothauma section}

Superficially very similar to the preceding section in all respects, including pattern. Fore wing with veins II and I2 touching or briefly anastomosed. Hind wing tailed and with a vestigial lobe in some species. Secondary sexual characters typically similar to Callictita; in some species the brands comprise streaks between and along the fore wing veins bearing either specialized hair scales or a mixture of hair and short plume scales; in $U$. antinorii (Oberthür) scent scales (Text-fig. 157) intermediate in appearance between short plume scales and ordinary battledore scales are arranged in alternate rows with the ordinary scales, but in far greater numbers than usual on the fore wing though in the normal proportion on the hind wing; there are no scent scales in Lycaena heritsia Hewitson, a species usually misplaced in Phlyaria. Eyes and palpi hairy. Male genitalia typically (Text-figs 90, 100) commonplace; penis with ductus entering on the dorsal surface, coecum not developed, suprazonal portion short and blunt; in $U$. nubifer (Text-fig. 9I) the genitalia differ considerably and the species should perhaps be included in a separate genus; the armature is more compact, the penis ends in a prominent Chapman's process and the juxta is abnormal in bearing two additional arms directed distad as well as the usual arms of the furca. African. Closely related to the next two sections.

Included genus: Uranothauma Butler, I895.

\section{Phlyaria section}

Fore wing with veins II and I 2 briefly anastomosed. Hind wing tailed. Pattern of under surface abnormal, white with yellowish wing bases, a black streak from base below fore wing cell, some small black costal and marginal spots and a black sub-basal spot astride vein ra of hind wing. Androconia of commonplace battledore type. Eyes hairy. Palpi bristly. Male genitalia (Text-fig. 99) similar to Uvanothauma, except that valvae are widely separated at their bases and juxta is shaped like three sides of a square. Single African species usually associated with $L$. heritsia (see above), but larvae are quite different (Jackson, 1937).

Included genus: Phlyaria Karsch, I895.

\section{Cacyreus section}

Fore wing with veins II and I $_{2}$ free. Hind wing tailed or tailless, with a vestigial lobe in Cacyreus and with cilia elongated at tornus in typical species of Harpendyreus. Androconia of commonplace battledore type. Eyes and palpi hairy. Male genitalia (Text-figs ro2, ro3) with uncus lobes bearing short to long tubercles; a sclerotized scaphium present in Cacyreus; penis generally similar to that of Uranothauma. African.

Included genera: Cacyreus Butler, I898 (= Hyreus Hübner, I8I9, praeocc.); Harpendyreus Heron, I909.

\section{Leptotes section}

Fore wing with veins I I and I 2 free. Hind wing tailed. Battledore androconia of ordinary shape. Eyes and palpi hairy. Male genitalia (Text-fig. I05) with brachia sometimes spinose or dentate; penis with ductus entering cephalad, suprazonal portion short and bearing a prominent, bifid Chapman's process. Holotropical, extending narrowly into the Holarctic Region.

Included genera: Leptotes Scudder, I876; Syntarucoides Kaye, I904, Cyclyrius Butler, I897; Syntarucus Butler, I900 (= Langia Tutt, I906). 


\section{Castalius section}

Fore wing, veins II and I 2 touch or anastomose. Hind wing tailed. Battledore scales, present only in Tarucus, of commonplace type. Eyes smooth. Palpi variable. Male genitalia (Text-fig. I04) very variable, especially among African species currently misplaced in Castalius (see Stempffer, 1967); penis, sometimes very small, with ductus entering cephalad, sub- and suprazonal portions subequal and the latter tapered, alulae present at zone; juxta variable, usually a furca bearing wide, curtain-like appendages (tectoria of Bethune-Baker) which enfold the penis, but may be reduced to a small lamella; valvae usually bearing large, internal spine-like processes (virgae excitatae of Bethune-Baker). African and Oriental, with slight extension into Palaearctic Region.

Included genera: Castalius Hübner, I8I9; Tarucus Moore, I88I.

\section{Zintha section}

Fore wing with veins II and I 2 free. Hind wing tailed. Pattern of under surface Castalius like. Battledore scales (Text-fig. I55) commonplace. Eyes smooth. Male genitalia (Text-fig. 107) quite unlike preceding section; brachia absent; vinculum broad and strongly convex; penis very curious, stout, ductus entering cephalad, sub- and suprazonal portions subequal with the latter divided into two separate processes, the upper wide and dentate, the lower narrow and more or less spatulate. Single African species.

Included genus: Zintha gen. n. (p. 453).

\section{Zizeeria section}

Fore wing with veins II and I 2 touching. Hind wing tailless. Battledore scales (Text-figs I4I, I43) rectangular, with their upper margins deeply concave in Zizina. Eyes smooth or hairy. Male genitalia (Text-fig. I06); penis with ductus entering on dorsal surface and with a short coecum; valvae bear tufts of long hairs, spines or other processes. African and Oriental, with slight extension into Palaearctic and Australian Regions. Probably fairly closely related to the next four sections.

Included genera: Zizeeria Chapman, I9ıо; Zizina Chapman, I9ıо; Pseudozizeeria Beuret, I955.

\section{Famegana section}

Fore wing with veins I I and I 2 touching briefly. Hind wing tailless. All markings on under surface obsolete except for obscure submarginal series. Battledore scales (Text-fig. I53) commonplace. Eyes smooth. Palpi bristly. Male genitalia (Text-fig. ro8) with dorsal structures heavy, uncus lobes ending in pointed processes, brachia stout and rather rigidly fixed to lateral processes of tegumen; penis widely open on dorsal surface, sub- and suprazonal portions subequal. Single Oriental and Australian species.

Included genus: Famegana gen. n. (p. 453).

\section{Actizera section}

Superficially similar to Zizeeria section, but veins II and I2 of fore wing are free. Battledore scales (Text-fig. I44), present in two out of three species, virtually indistinguishable from those of Zizeeria. Eyes smooth. Palpi hairy. Male genitalia (Text-figs III, II2): penis with ductus entering ventro-cephalad; in two species the valvae bear short, transtilla-like costal processes directed inwards. African.

Included genus: Actizera Chapman, I9ro.

\section{Zizula section}

Fore wing with veins II and I2 anastomosed to costa. Hind wing tailless. No androconia. Male genitalia (Text-fig. I Io) very abnormal; penis short and stout with ductus entering ventro- 
cephalad, suprazonal portion divided into two tapered processes resembling a beak, subzonal portion with a short 'footstalk', valvae bifid and furnished with a very long, flexible rod-like process, a basal arm turned inwards and a tuft of long spines. Holotropical.

Included genus: Zizula Chapman, Igro.

\section{Brephidium section}

Fore wing with veins II and I2 anastomosed to costa, as in Zizula except that in Oraidium vein I I arises from vein ro. Hind wing tailless. Battledore scales, present only in Brephidium, narrow in American species (Text-fig. 142), commonplace in African species. Eyes smooth. Palpi hairy. Male genitalia with highly abnormal dorsal structures of uncertain homology, lateral processes of tegumen bearing finger- or rod-like, hairy or spinous processes, also one (Brephidium) or two (Oraidium-Text-fig. Io9) additional processes between uncus lobes; penis beak-like, as in Zizula but without a 'footstalk' in Oraidium; for further details see Stempffer (1967: Text-figs 218-221). Discontinuous and relict distribution in South Africa and Sonoran zone of Nearctic extending into northern part of Neotropical Region.

Included genera: Brephidium Scudder, I876; Oraidium Bethune-Baker, I9I4.

\section{Everes section}

Fore wing with veins II and 12 anastomosed briefly. Hind wing tailless or tailed. Battledore scales (absent in brown species) commonplace. Eyes smooth. Palpi hairy or bristly. Male genitalia (Text-fig. I 6 ) with uncus not divided into separate lobes though weakly excavate in typical genera; brachia small; penis with sub- and suprazonal portions subequal, ductus entering cephalad; valvae often bear internal projections recalling the 'virgae excitatae' of Castalius section. Mainly Palaearctic, but extending into Oriental, Australian and Nearctic Regions. Rather closely related to next two sections.

Included genera: Everes Hübner, I8I9 (= Ununcula van Eeeke, I9I5); Cupido Schrank, I80I (= Zizera Moore, I88I); Tiora Evans, I9I2; Bothrinia Chapman, I909 (= Bothria Chapman, I908, praeocc.); Tongeia Tutt, I908; Shijimia Matsumura, I9I9; Talicada Moore, I88I; Binghamia Tutt, I908 (based on misidentified typespecies).

\section{Pithecops section}

Fore wing with veins II and I2 anastomosed, sometimes as far as costa. Hind wing tailless. No androconia. Eyes smooth. Palpi hairy. Male genitalia (Text-fig. II5) similar to Everes section except that uncus is broadly divided almost to its base. Oriental.

Included genus: Pithecops Horsfield, r828; Eupsychellus Röber, I89I.

\section{Azanus section}

Fore wing with veins II and I 2 anastomosed briefly. Hind wing tailless. Androconia of two rather abnormal types: long paddle scales (Text-fig. 149) and rather rectangular battledore scales with concave bases (Text-fig. 146) as in Upolampes and Pseudonacaduba. Eyes hairy. Palpi hairy or bristly. Male genitalia (Text-fig. II4) broadly resemble those of Everes section except that uncus is narrowly divided. African and Oriental.

Included genus: Azanus Moore, I88r.

\section{Eicochrysops section}

Fore wing with veins I I and I 2 free. Hind wing tailed or tailless. Battledore scales commonplace. Eyes smooth. Palpi bristly. Male genitalia (Text-fig. II3) distinguished by uncus 
bearing two lobes, the upper pair 'rolled up like a cornet' (Stempffer, 1967: 237); penis rather small, with ductus entering dorso-cephalad. African.

Included genus: Eicochrysops Bethune-Baker, I924.

\section{Lycaenopsis section}

Fore wing with veins I I and I 2 free. Hind wing tailless except for a short tail in one species. Battledore scales commonplace. Eyes and palpi smooth or hairy. Male genitalia with uncus lobes usually produced, sometimes to a stout spike, and turned inwards and downwards; brachia usually absent or vestigial; vinculum with a pronounced subtriangular extension directed cephalad; penis with ductus entering on dorsal surface, coecum more or less developed, sometimes, as in Rhinelephas (Text-fig. I I 7), of great length, suprazonal portion short, bearing a single Chapman's process of variable length. Oriental extending into Holarctic.

Included genera: Lycaenopsis C. \& R. Felder, I865; Neopithecops Distant, I884; Parapithecops Moore, I884; Megisba Moore, I88I; Pathalia Moore, I884; Arletta Hemming, I935 (= Moorea Toxopeus, I927, praeocc.); Celastrina Tutt, I906; Notarthrinus Chapman, I908; Acytolepis Toxopeus, I927; Oreolyce Toxopeus, I927; Monodontides Toxopeus, I927; Akasinula Toxopeus, I928; Ptox Toxopeus, I928; Udara Toxopeus, I928; Rhinelephas Toxopeus, I928; Uranobothria Toxopeus, I928; Parelodina Bethune-Baker, I904; Vaga Zimmerman, I958; Papua Röber, I892, invalid, praeocc.; Cyaniriodes Matsumura, I9I9, invalid, praeocc.

\section{Glaucopsyche section}

Fore wing with veins II and I2 free. Hind wing tailless. Battledore scales commonplace. Eyes smooth or hairy. Palpi hairy or bristly. Male genitalia (Text-fig. II8) commonplace; penis with ductus entering dorso-cephalad or cephalad, no coecum, suprazonal portion short; in Glaucopsyche a small saccus directed ventrad. Holarctic, extending very weakly into Oriental Region.

Included genera: Glaucopsyche Scudder, I872; Phaedrotes Scudder, I876; Scolitantides Hübner, I8I9; Apelles Hemming, I93I; Philotes Scudder, I876; Turanana Bethune-Baker, I9I6 (= Turania Bethune-Baker, I9I4, praeocc.); Palaeophilotes Forster, 1938; Praephilotes Forster, I938; Pseudophilotes Beuret, I955; Shijimiaeoides Beuret, I955; Sinia Forster, I940; Iolana Bethune-Baker, I9I4; Maculinea van Eecke, I9I5; Caerulea Forster, I938; Phengaris Doherty, I89I.

\section{Euchrysops section}

Fore wing with veins I I and I 2 free. Hind wing tailed or tailless. Battledore scales commonplace. Eyes smooth or hairy. Male genitalia (Text-fig. II9); penis with alulae at zone, ductus entering cephalad, sub- and suprazonal portions usually subequal, but latter may be rather short; juxta a furca with short arms. African, with very weak extension into Oriental and Australian Regions.

Included genera: Euchrysops Butler, I900; Lepidochrysops Hedicke, I923 (= Neochrysops Bethune-Baker, I923, praeocc.); Thermoniphas Karsch, I895; Oboronia Karsch, I893; Athysanota Karsch, I895.

\section{Polyommatus sect on}

Fore wing with veins II and I 2 free. Hind wing tailless in Holarctic species but often tailed in tropical species. Battledore scales (Pl. 5, figs 25-30 and Text-figs I47, I50) commonplace, except in Itylos (Text-fig. 145) in which the outer margins are excavate or crenulate; in addition 
'gelbe schuppe' (Text-fig. г5ов) may be present. Eyes and palpi variable. Male genitalia (Text-figs I 2O, I2I) with lobes of uncus more or less digitate and directed caudad; a suspensorium, comprising a pair of rather weakly sclerotized arms descending from the top of the inner faces of the lateral processes of the tegumen, is nearly always present; penis generally similar to that of the Euchrysops section, with alulae at the zone; in Neotropical species a sagum (p. 39I) is nearly always present. Cosmopolitan.

Included genera: Polyommatus Latreille, I804; Plebejus Kluk, I802; Lycaeides Hübner, I8I9; Cyaniris Dalman, I8I6; Nomiades Hübner, I8I9; Aricia R. L., I8I7 (= Gynomorphia Verity, I929); Pseudoaricia Beuret, I959; Kretania Beuret, I959; Ultraaricia Beuret, I959; Agriades Hübner, I8I9; Vacciniina Tutt, I909; Albulina Tutt, I909; Bryna Evans, I9I2; Meleageria Sagarra, I925; Agrodiaetus Hübner, I822 (= Hirsutina Tutt, I909) ; Lysandra Hemming, I933 (= Uranops Hemming, I929, praeocc.); Plebicula Higgins, I969; Eumedonia Forster, I938; Plebulina Nabokov, I944; Icaricia Nabokov, I944; Chilades Moore, I88I; Edales Swinhoe, I9I0; Luthrodes H. H. Druce, I895; Freyeria Courvoisier, I920; Hemiargus Hübner, I8I8; Itylos Draudt, I92I; Pseudochrysops Nabokov, I945; Cyclargus Nabokov, I945; Echinargus Nabokov, I945; Pseudolucia Nabokov, I945; Paralycaeides Nabokov, I945; Nabokovia Hemming, I960 (= Pseudothecla Nabokov, I945, praeocc.); Parachilades Nabokov, I945.

\section{DESCRIPTIONS OF NEW GENERA}

\section{COWANIA gen. n.}

Gender feminine. Type- and sole species: Horaga achaja Fruhstorfer, I9I2.

Allied to Drupadia Moore, I884, with which it agrees fairly closely in the shape of the fore wing and in lacking veins 8 and 9, in the smooth eyes, flat-scaled palpi and stubby-tipped male fore tarsus. Antenna with cylindrical club a little stouter and more abrupt than in Drupadia, with the tapered nudum extending a little over half way down the shaft. Hind wing rather different to Drupadia, without a tail or tooth at vein 3 though the termen is stepped there, a tail about $2.5 \mathrm{~mm}$ long at vein $\mathrm{Ib}$ with its inner edge ciliate and a longer filamentous tail about $4^{\circ} \mathrm{O} \mathrm{mm}$ long at vein 2 (exactly as in Horaga; in Drupadia this tail is longer, broader, ciliate on both sides and the vein is continued some distance down it). On the upper surface of the male hind wing there is a rather ill-defined subcostal black patch and there is a rather similar patch above the dorsum on the under surface of the fore wing, both patches being composed of scales which are not strongly modified and do not give the impression of being scent scales.

Male genitalia (Text-fig. 42) similar in structure to Drupadia, but comparatively about twice as large. Vinculum narrow, ending in a small saccus which is continued in the same plane downwards. Uncus and tegumen not differentiated, comprising large, widely separated, triangular processes with their apices twisted and ending in a small up-turned spoon and their bases fused to the vinculum as far as the saccus (in Drupadia the uncus-tegumen complex ends in long, gently curved, digitate processes). Brachia absent. Valvae large, triangular, ending in a down-curved hook, hinged to the extreme base of the vinculum and top of the saccus and also connected by a membrane at the end of a costal arm to the inner face of the uncus-tegumen complex. Juxta absent.

The genus is dedicated to my friend and old collecting companion Lt.-Col. C. F. Cowan, who first pointed out (I966a: I08) that the type-species was not a Horaga, but was structurally related to 'Marmessus', a name generally misused in the past for Drupadia until Cowan (I966b) pointed out the error. 


\section{ACUPICTA gen. n.}

Gender neuter. Type-species: Catapoecilma (sic) delicatum de Nicéville, I887.

Nearest to Catapaecilma Butler, I879, but differing in many respects. Eyes smooth (hairy in Catapaecilma though sparsely so in one species). Palpi hairy, third joint short. Antenna with gradual, cylindrical club; segments number about 37, those on the shaft being only a little longer than wide; shaft with white segmental bands on the upper surface; on the lower surface the nudum is continuous, but with its edges slightly indented at each segment, and reaches almost half-way to base in male and two-thirds to base in female; thereafter continuing in a few detached patches (in Catapaecilma the nudum is crossed by bands of scales which commence half-way down the club). Legs generally as in Catapaecilma, with male fore tarsus ending in a tapered, down-curved point. Wing shape and venation as in Text-fig. $47 \mathrm{~A}$, the most unusual feature being the false tornus between veins $\mathrm{Ib}$ and 2 ; hind wing typically with filamentous tails at veins $\mathrm{Ib}, 2$ and 3 , that at vein 2 being the longest, but in an unnamed species from the Papuan subregion there is a fourth short tail at vein 4. Upper surface powdery blue in both sexes with broad fuscous borders; under surface ochreous densely striated with brown and bearing a large number of small metallic silver streaks which are difficult to reconcile with the normal Lycaenid pattern. Male without secondary sexual characters (present in all species of Catapaecilma). Male genitalia (Text-fig. $47 \mathrm{~B}, \mathrm{C}$ ) with the dorsal parts recalling those of Catapaecilma, but differing in lacking a juxta and in having comparatively smaller valvae and a larger penis.

Hypochrysops bubases Hewitson, I875, only known to me by the female holotype, is provisionally placed in this new genus.

Catapaecilma should have been spelled Catapoecilma by its author, and some subsequent authors have used this spelling. However, under the Code this emendation is not justified. The name is clearly intended to describe the brocade-like under surface markings; Acupicta was suggested to me by Lt.-Col. C. F. Cowan as a very rough Latin equivalent.

\section{PSEUDOTAJURIA gen. n.}

Gender feminine. Type- and sole species: Tajuria donatana de Nicéville, I888.

Nearest to Ancema nom. n. (see p. 438), of which it should possibly rank as a subgenus. It differs from Ancema as follows. Fore wing narrower and hind wing less produced. Fore wing with vein 7 relatively long, arising well before the end of the cell and remote from vein 6 ; vein 9 relatively short, arising well beyond the centre point of vein 7 (in Ancema vein 7 arises just before the apex of the cell and close to vein 6 whilst vein 9 is long, arising from vein 7 just before its centre point). The hind wing cell is half the breadth of the wing, the upper discocellular vein is much shorter than the lower and the latter is inclined basad so that it is nearly parallel to the termen (in Ancema the cell is less than half the wing, the upper and lower discocellular veins are equal and more or less in direct continuation of one another, so that the lower corner of the cell is very acute). The under surface pattern, yellow with green subtornal markings on the hind wing, is rather close to that of Remelana, whereas that of Ancema, with subtornal orange markings above tornal black spots, resembles that of many genera of Iolaini. No secondary sexual characters (present on all wings of Ancema). Eyes smooth (clothed with 
long hairs in the type species of Ancema, though smooth in Ancema blanka de Nicéville, a species tentatively included in Ancema because of the similarity of its male genitalia to the type-species despite considerable differences in venation and secondary sexual characters. Antenna with club a little more abrupt and nudum a little less extensive than in Ancema. Palpi with third joint slender and half the length of the second joint in both sexes (in Ancema the third joint is a little longer than half the second joint in the male and nearly as long as the second joint in the female). Male genitalia (Text-fig. 62) of a similar pattern to those of Ancema (Text-fig. 63), though differing in detail as follows: brachia longer and thinner, valvae basally conjoined for a shorter distance and with a much shorter lower process, penis shorter and stouter vinculum less inclined.

\section{TITEA gen. $\mathbf{n}$.}

Gender feminine. Type-species: Candalides sublutea Bethune-Baker, Igo6.

The type-species was included by Tite (1963) in Philivis, but it differs structurally from all but one of the other included species by possessing in the male a segmented and fully functional fore tarsus bearing twin claws. The male genitalia are also fairly distinctive in possessing valvae which are broadly united ventrally (Tite: fig. 68). Colour and pattern are also distinctive; on the upper surface the male is metallic blue or bluish green with broad black borders, and on the under surface both sexes are rich yellow or orange and unmarked except for a series of metallic silver submarginal dashes. In the type-species the female hardly differs externally from the male.

Clench (I955: 269) pointed out long ago that a new genus was required for a new species near 'Candalides' sublutea, and it is with his permission that I now describe this genus. Clench states (in litt.) that his species has since been identified as Philiris caerulea Tite, I963, which is the only other species to be included in Titea. P.caerulea was described by Tite from a single male from the Rawlinson Mts. However it is of interest that there are in the British Museum (Natural History) two females from New Guinea with brown wings both bearing large orange patches and with the under surface paler and yellower but otherwise similar to T. caerulea. As one of them bears the same data as the holotype of $T$. caerulea, it seems likely that they will eventually prove to be females of this species.

The genus is dedicated to Mr G. E. Tite, lately on the staff of the British Museum (Natural History) in recognition of his outstanding contribution to our understanding of the very difficult 'omnibus' genus Philiris and in gratitude for many past kindnesses.

\section{RYSOPS gen. n.}

Gender feminine. Type-species: Lycaena scintilla Mabille, I877.

Stempffer (I968:238, fig. 204) has already drawn attention to the unique characters of the type- and sole included species, and it is with his permission that I name 
this new genus. Aurivillius included the type-species in Eicochrysops BethuneBaker, I924, but I believe that it is most nearly related to Catochrysops Boisduval, I832, to which it bears a striking resemblance both in its external pattern and in the very unusual structure of the male battledore androconia (Text-figs I39, I40), already discussed on p. 406. It also has generally similar eyes, palpi, antennae and legs, but differs in having veins II and I2 of the fore wing completely free, whereas they touch briefly in Catochrysops. The male genitalia (Text-fig. 96; also, in more detail, Stempffer, I967 : fig. 204) do not closely resemble those of any other genus.

The name Rysops has no meaning, but is intended to suggest a relationship with Catochrysops.

\section{FAMEGANA gen. n.}

Gender masculine. Type- and sole species Lycaena alsulus Herrich-Schäffer, I869.

The type-species has been placed by recent authors in Zizina or Zizeeria, with both of which it shares a general similarity in size, appearance and habits.

Eyes smooth (hairy in Zizina). Palpi with second joint clothed with bristly scales, third joint long, slender, acuminate. Venation commonplace, with veins II and I2 of the fore wing briefly touching, as in the Zizeeria section. Under surface of the wings unmarked except for the usual submarginal series, which may fade out in dry season forms. Male with commonplace battledore androconia (Text-fig. I53), unlike the rectangular androconia of the Zizeeria section (Text-figs I4I, I43). Male genitalia (Text-fig. I08) unlike those of any other species known to me, the principal peculiarity being the very stout brachia which are hinged wholly to the lateral processes of the tegumen and are capable of only limited movement.

'Famegana' is the northern Queensland aboriginal word for 'small', and was suggested to me for this little species by Mr L. E. Couchman.

\section{ZINTHA gen. $\mathrm{n}$.}

Gender feminine. Type- and sole species: Lycaena hintza Trimen, I864.

The type-species has been included by recent authors in Castalius, itself an 'omnibus' genus requiring subdivision, where, as pointed out by Stempffer (1967:207), it has occupied a particularly anomalous position. In venation it differs from all 'Castalius' species in having veins I I and I 2 of the fore wing completely free. Externally it differs from the usual black and white pattern in being plain blue on the upper surface in the male and in bearing battledore androconia (Text-fig. I55). Male genitalia (Text-fig. 107; also Stempffer, 1967: fig. 177, in which the penis is drawn upside down) vaguely recall the genitalia of the Lycaenopsis section by the absence of brachia and strongly curved vinculum, but the penis is of an unique shape.

As the male genitalia are so different to those of all the other species of the Castalius section which are known to me, I have placed Zintha in a section by itself. 
List of new combinations resulting from the above descriptions:-

Cowania achaja (Fruhstorfer) comb. $\mathbf{n}$.

Acupicta delicatum (de Nicéville) comb. $\mathbf{n}$.

Acupicta bubases (Hewitson) comb. $\mathbf{n}$.

Pseudotajuria donatana (de Nicéville) comb. n.

Titea sublutea (Bethune-Baker) comb. n.

Titea coerulea (Tite) comb. $\mathbf{n}$.

Rysops scintilla (Mabille) comb. $\mathbf{n}$.

Famegana alsulus (Herrich-Schäffer) comb. n.

Zintha hintza (Trimen) comb. $\mathbf{n}$.

PHYLOGENY AND ZOOGEOGRAPHY

\section{Phylogeny}

In working out a suggested phylogeny of the butterflies the chief difficulty is uncertainty as to what was the primitive state of any character. A further difficulty lies in deciding the extent to which characters may have been secondarily modified or lost. For example, the abdominal brush organs in Liptenini and the Neotropical Eumaeini might be explained as secondary specializations which have evolved separately and by coincidence in these two rather widely separated groups (both morphologically and geographically), which on this account should be regarded as advanced. On the other hand, abdominal brush organs occur in a variety of forms in the butterfly family Danaidae and in a great many moths; so an alternative explanation of their presence is that they have evolved from an ancestral organ which was once present in all the Lepidoptera but which has since been entirely lost in most groups. If the latter explanation is correct, then on this account the Liptenini and Neotropical Eumaeini should be regarded as the most primitive Lycaenid groups.

In Table A I list I9 characters-mainly external and from a phylogenetic point of view probably not the most significant-with my opinion as to their primitive or specialized states. In Table B I consider each character in relation to my proposed classification into subfamilies and tribes, scoring each out of Io with the exception of the male genitalia scored out of 20 . It will be seen that all my groups contain, in varying proportions, a mixture of primitive and specialized characters. This was to be expected, and the tables are mainly of interest as indicating the broad degree of specialization which each group has undergone. The mixture of primitive and specialized characters does, however, serve to emphasize the difficulties inherent in basing phylogenies on single characters, as was attempted by Jordan (1898) using the antennae (see p. 377). The hypothetical family-tree in Text-fig. I has therefore been based partly on an intuitive evaluation of the selected diagnostic characters. 


\section{TABLE A}

\begin{aligned} & \multicolumn{1}{c}{ Character } \\ I & Male genitalia \\ & \\ & \\ 2 & Hind wing shape \\ 3 & $\begin{array}{l}\text { Number of fore wing } \\ \text { veins }\end{array} \\ 4 &$ Veins I I and I2 of \\ & fore wing \\ 5 & Hind wing precostal \\ & vein \\ 6 & Pattern \\ 7 & Eyes \\ 8 & Antennal club \\ 9 & Antennal nudum \\ I0 & Palpi \\ & \\ I I & Proboscis \\ I 2 & Legs \end{aligned}

I3 Male fore tarsus

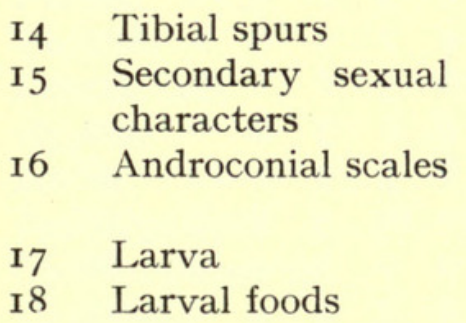

I9 Pupa
Primitive (a)

All components present, relatively simple and of average development

Tailless and lobeless

I 2 veins

Free

Present

Normal Lycaenine

Smooth

Gradual and cylindrical

Extending down shaft

Average length, symmetrical

Smooth, average length

Subcylindrical and of average development

Segmented and clawed

Present

Absent

Barely differing from ordinary scales

Onisciform

Feeding exclusively on green plants

Girdled or reclining
Specialized (b)

One or more components absent or strongly modified or with additional components, or asymmetrical

Tailed and lobed

Io or I I veins

Anastomosed or linked

Absent

Strongly modified or mimetic

Hairy

Abrupt, flattened or hollowed

Confined to club

Very short, or long, or asymmetrical

With sensory hairs, or atrophied Abnormal (e.g. swollen, flattened or bearing terminal projections on coxae or tibiae)

Fused to a single segment (stubby-tipped more specialized than pointed)

Absent

Present

\section{Strongly differentiated}

Differently shaped

Different diet (e.g. partly or wholly carnivorous, or feeding on lichen)

Ungirdled

\section{TABLE B}

Tribe

Pentilini

$\begin{array}{lllllllllllllllllllll}\mathrm{a} / \mathrm{b} & \text { I } & 2 & 3 & 4 & 5 & 6 & 7 & 8 & 9 & \text { I0 } & \text { II } & \text { I2 } & \text { I3 } & \text { I4 } & \text { I5 } & \text { I6 } & \text { I7 } & \text { I } 8 & \text { I9 } & \text { Total }\end{array}$

Liptenini

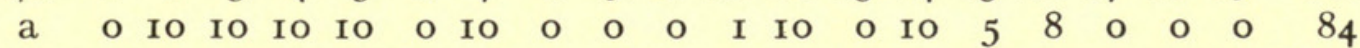

b 20 o

$\begin{array}{lllllllllllllllllllll}a & \text { I0 } & \text { Iо } & 9 & 8 & 4 & \text { 0 } & \text { I0 } & 3 & 5 & 9 & \text { I } & 9 & \text { 0 } & \text { Iо } & 2 & 5 & \text { 0 } & \text { 0 } & \text { 0 } & 95\end{array}$

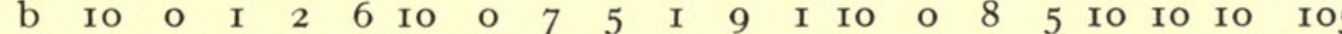

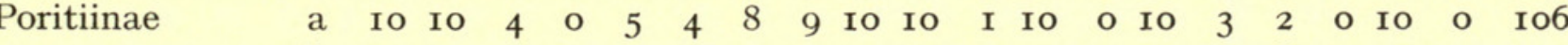

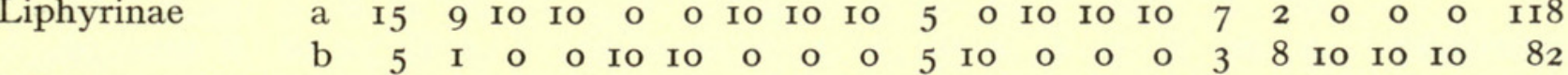

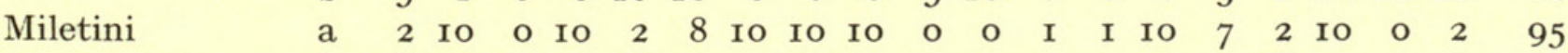

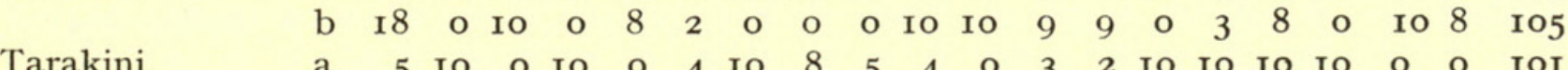

$\begin{array}{llllllllllllllllllllll} & \text { a } & 5 & \text { 10 } & 0 & \text { I0 } & 0 & 4 & \text { 10 } & 8 & 5 & 4 & 0 & 3 & 2 & \text { Io } & \text { Io } & \text { 10 } & \text { 10 } & 0 & 0 & \text { Ior }\end{array}$

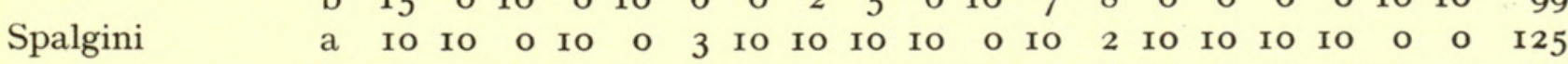

b Iо о го о го 7 о 
Table B. continued.

Tribe $\mathrm{a} / \mathrm{b} \quad \begin{array}{lllllll}\mathrm{I} & 2 & 3 & 4 & 5 & 6\end{array}$ $\begin{array}{llllllllllllll}7 & 8 & 9 & \text { Io } & \text { II } & \text { I2 } & 13 & \text { I4 } & \text { I5 } & \text { I6 } & \text { I7 } & \text { I8 } & \text { I9 }\end{array}$ Total

Lachnocnemini

Curetinae

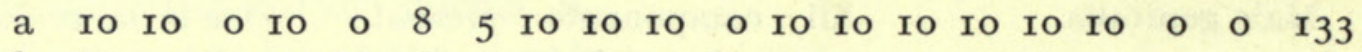

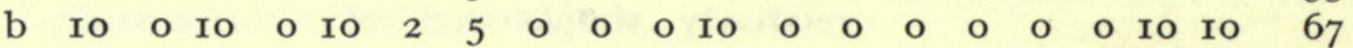

Luciini

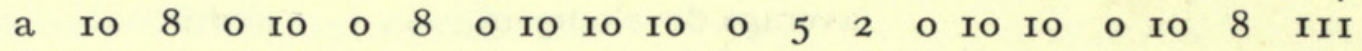

b IO 2 IO 0 IO 2 I0 0 o

Theclini

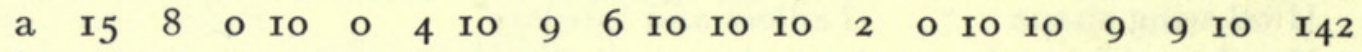

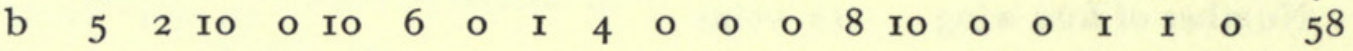

Arhopalini

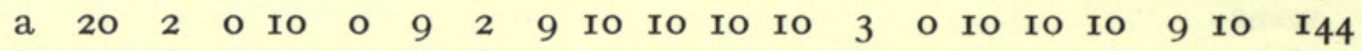

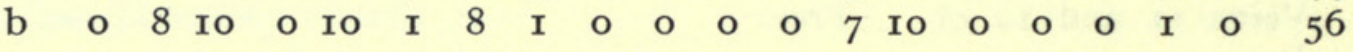

Ogyrini

a 20 I 0 Io 0 Io Io Io Io Io Io Io 0 o Io Io Io Io Io $I_{5} \mathrm{I}$

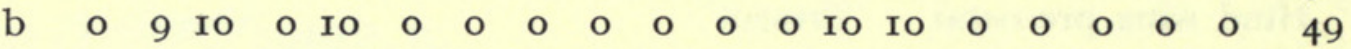

Zesiini

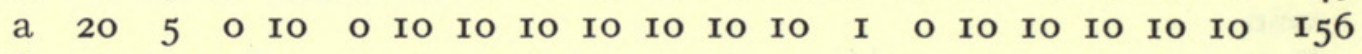

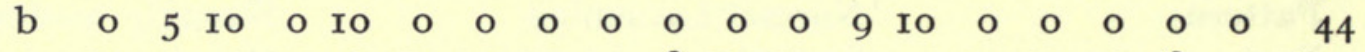

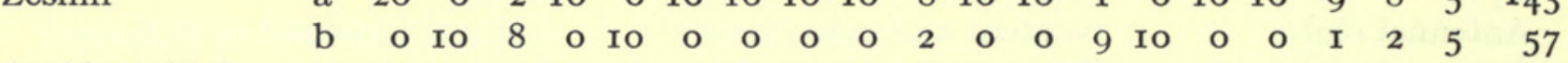

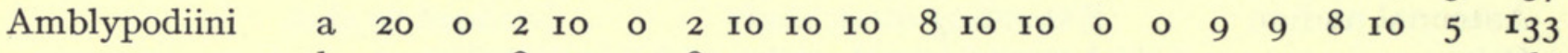

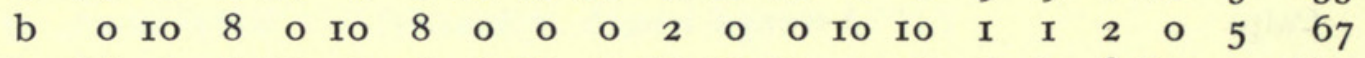

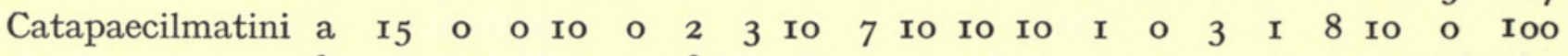

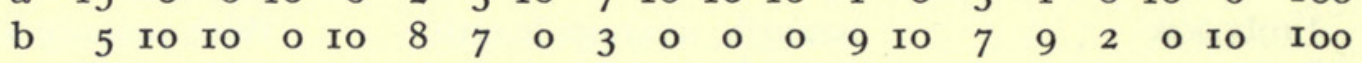

Oxylidini a 5 o o ro o ro ro ro o ro ro ro 1 o ro ro - $-\quad$ - 96

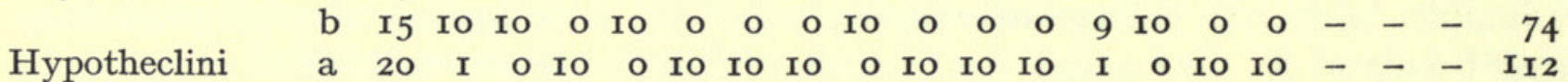

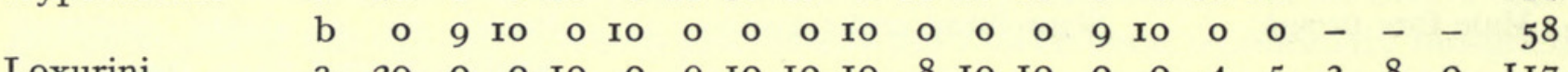

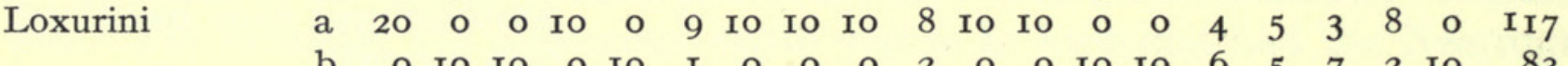

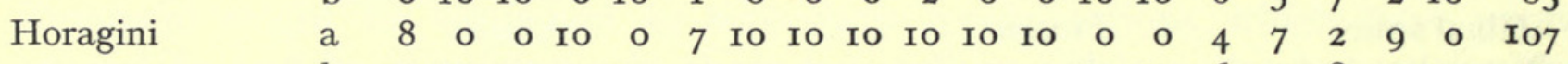

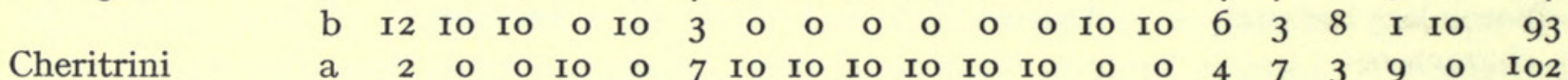

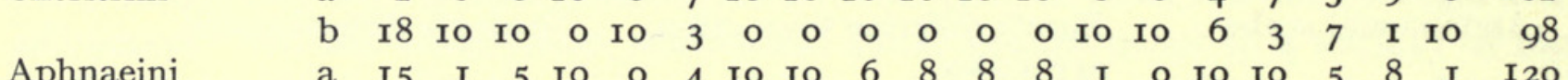

$\begin{array}{llllllllllllllllllllll} & \mathrm{b} & 5 & 9 & 5 & \mathrm{o} & \text { 10 } & 6 & 0 & 0 & 4 & 2 & 2 & 2 & 9 & 10 & 0 & 0 & 5 & 2 & 9 & 80\end{array}$

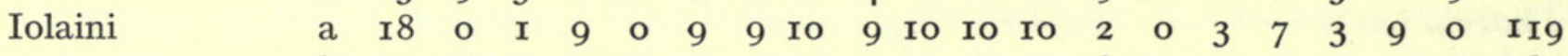

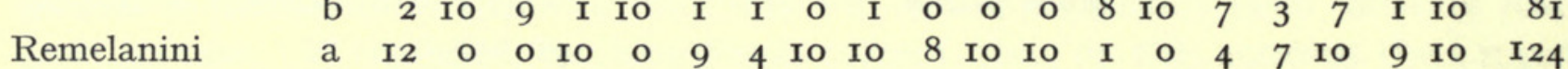

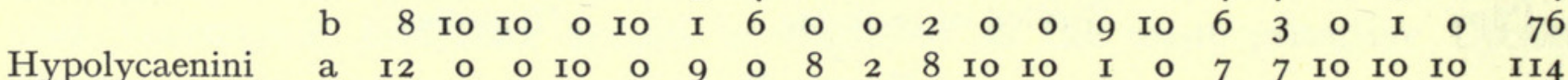

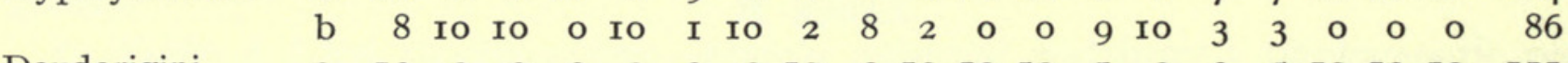

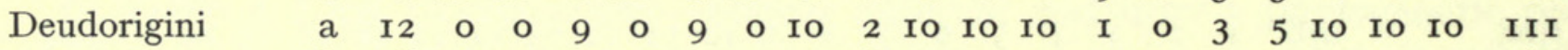

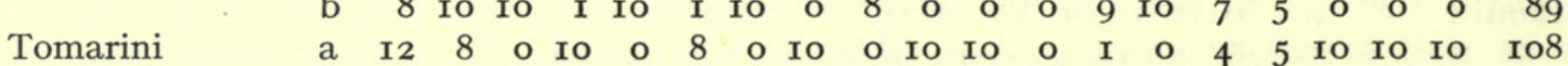

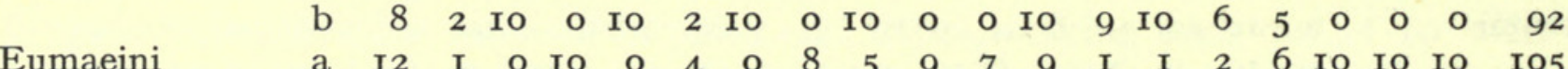

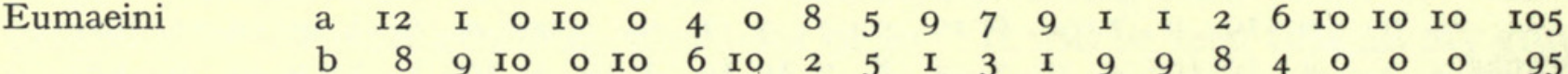

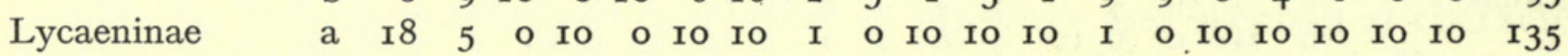

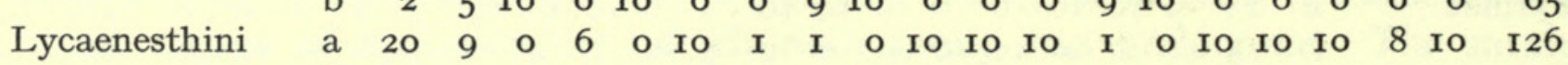

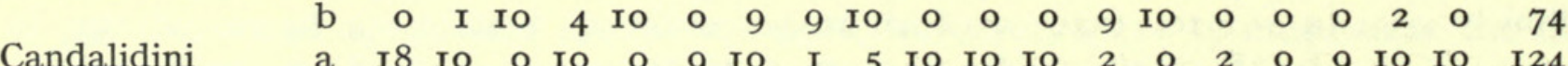

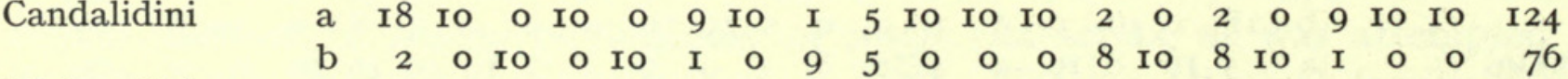

Niphandini a 20 Iо

b 0 o

$\begin{array}{lllllllllllllllllllll}\text { a } & \text { I7 } & 5 & 0 & 5 & 0 & 9 & 4 & 0 & 0 & 9 & \text { 10 } & \text { Io } & \text { I } & \text { o } & 2 & \text { o } & \text { 10 } & 8 & \text { 10 } & \text { 100 }\end{array}$

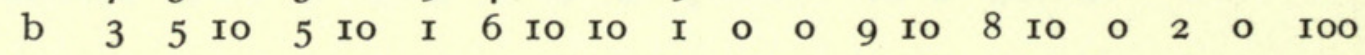

The scoring of characters (out of ro, except male genitalia out of 20). Second column indicates (a) primitive, (b) specialized. The characters are numbered as in Table A. In the case of Oxylidini and Hypotheclini nothing is known of the early stages and characters $17-19$ are not scored. 


\section{ZOOGEOGRAPHY}

In the absence of all but the most meagre fossil record the zoogeography of the butterflies must be deduced from their present distribution, their present powers of dispersal and our still limited knowledge of palaeogeography.

In Table C I summarize the present distribution of the Lycaenid subfamilies and tribes and in Table $\mathrm{D}$ the distribution of the sections of the very large tribe Polyommatini. My delimitation of the Ethiopian, Neotropical and Nearctic Regions follows conventional lines. In the case of the Oriental Region, I accept the view of Gressitt (I956) who, using evidence mainly derived from the Coleoptera, considered

\section{TABLE C}

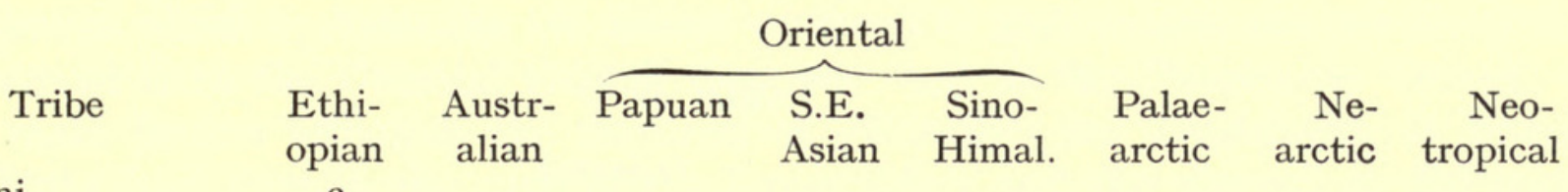

Liptenini

Pentilini

Poritiinae

Liphyrinae

Miletini

Tarakini

Spalgini

Lachnocnemini

Curetinae

Luciini

Theclini

Arhopalini

Ogyrini

Zesiini

Amblypodiini

Catapaecilmatini

Oxylidini

Hypotheclini

Loxurini

Horagini

Cheritrini

Aphnaeini

Iolaini

Remelanini

Hypolycaenini

Deudorigini

Tomarini

Eumaeini

Lycaeninae

Lycaenesthini

Candalidini

Niphandini

Polyommatini

\section{c}

C

b

a

a

c

b

b

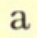

c

C

\section{c}

c

(a)

(a)

(a)

b

b

(a)

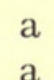

$\mathrm{a}$

a $a$

a

a b

c

c

a

$\mathrm{a}$

a $\quad b$

a b

a $\quad$ a

$b$

a $\quad$ b $\quad$ a

c

b b b

c $\quad b \quad a$

b

b

c

b

$\mathrm{a}$

$\mathrm{a}(\mathrm{NZ})$

(a)

b

a

b

b

a

c

b a

c $\quad$ c

$\begin{array}{lll}\mathrm{a} & \mathrm{b} & \mathrm{a}\end{array}$

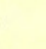

(a)

$\begin{array}{lll}\mathrm{a} & & \\ \mathrm{b} & & \\ \mathrm{b} & \mathrm{a} & \\ \mathrm{c} & & \\ \mathrm{b} & \mathrm{b} & \mathrm{b} \\ \mathrm{c} & \mathrm{b} & \mathrm{a} \\ \mathrm{b} & & \end{array}$

$\mathrm{a}$

a (1)

The distribution of Lycaenid tribes. $\quad \mathrm{a}=\mathrm{I}-4$ species, $\mathrm{b}=5-20$ species, $\mathrm{c}=$ more than 20 species. In the case of the Australian Region, groups are placed in brackets when all the component species are thought to have arrived since the start of the Pleistocene Period and are confined to Queensland and/or Northern Territory. 
that it extended from the Yangtse Basin in the north to Ceylon and through the Malay Archipelago to the Cape York Peninsula of Australia and to the whole of Polynesia. Its butterfly fauna is decidedly mixed, so that it is best divided, albeit somewhat arbitrarily, into subregions. In doing so I have disregarded the Polynesian Subregion of Gressitt, since it is unimportant in considering the origin of the Lycaenidae, and have modified his other subregions. The S.E. Asian Subregion (sensu mihi) comprises virtually the whole of the Oriental Region in its traditional, restricted sense and extends from S.E. China to Ceylon and as far east as Weber's Line; its characteristic species are lowland or submontane in habit and appear to be centred in Sundaland. The Papuan Subregion lies east of Weber's Line. What I have elsewhere termed the Sino-Himalayan Subregion (Eliot, I969) is a particularly

\section{TABLE D}

\begin{tabular}{|c|c|c|c|c|c|c|c|c|}
\hline \multirow[b]{2}{*}{ Section } & \multirow[b]{2}{*}{$\begin{array}{l}\text { Ethi- } \\
\text { opian }\end{array}$} & \multirow[b]{2}{*}{$\begin{array}{c}\text { Austr- } \\
\text { alian }\end{array}$} & \multicolumn{3}{|c|}{ Oriental } & \multirow[b]{2}{*}{$\begin{array}{l}\text { Palae- } \\
\text { arctic }\end{array}$} & \multirow[b]{2}{*}{$\begin{array}{l}\mathrm{Ne}- \\
\text { arctic }\end{array}$} & \multirow[b]{2}{*}{$\begin{array}{l}\text { Neo- } \\
\text { tropica }\end{array}$} \\
\hline & & & Papuan & $\begin{array}{l}\text { S.E. } \\
\text { Asian }\end{array}$ & $\begin{array}{l}\text { Sino- } \\
\text { Himal. }\end{array}$ & & & \\
\hline Cupidopsis & $\mathrm{a}$ & & & & & & & \\
\hline Una & & & & $\mathrm{a}$ & $\mathrm{a}$ & & & \\
\hline Petrelaea & $\mathrm{a}$ & & $\mathrm{a}$ & $\mathrm{a}$ & & & & \\
\hline Nacaduba & & $\mathrm{b}$ & $\mathrm{c}$ & c & & & & \\
\hline Theclinesthes & & $\mathrm{b}$ & $\mathrm{a}$ & & & & & \\
\hline Danis & & (a) & $\mathrm{c}$ & $\mathrm{a}$ & & & & \\
\hline Upolampes & & & $\mathrm{b}$ & $\mathrm{b}$ & & & & \\
\hline Jamides & & (b) & $\mathrm{b}$ & $\mathrm{c}$ & & & & \\
\hline Catochrysops & $\mathrm{a}$ & (a) & $\mathrm{b}$ & $\mathrm{a}$ & & & & \\
\hline Lampides & $\mathrm{a}$ & $\mathrm{a}$ & $\mathrm{a}$ & $\mathrm{a}$ & $\mathrm{a}$ & $\mathrm{a}$ & & \\
\hline Callictita & & & $\mathrm{a}$ & & & & & \\
\hline Uvanothauma & $\mathrm{b}$ & & & & & & & \\
\hline Cacyreus & $\mathrm{b}$ & & & & & & & \\
\hline Leptotes & $\mathrm{b}$ & (a) & $\mathrm{a}$ & $\mathrm{a}$ & & $\mathrm{a}$ & $\mathrm{a}$ & $\mathrm{b}$ \\
\hline Phlyaria & $\mathrm{a}$ & & & & & & & \\
\hline Castalius & c & & & $\mathrm{b}$ & $\mathrm{a}$ & $\mathrm{a}$ & & \\
\hline Zintha & $\mathrm{a}$ & & & & & & & \\
\hline Famegana & & $\mathrm{a}$ & $\mathrm{a}$ & $\mathrm{a}$ & & & & \\
\hline Zizeeria & $\mathrm{a}$ & $\mathrm{a}$ & $\mathrm{a}$ & $\mathrm{a}$ & & $\mathrm{a}$ & & \\
\hline Actizera & $\mathrm{a}$ & & & & & & & \\
\hline Zizula & $\mathrm{a}$ & $\mathrm{a}$ & $\mathrm{a}$ & $\mathrm{a}$ & & & $\mathrm{a}$ & $\mathrm{a}$ \\
\hline Brephidium & $\mathrm{a}$ & & & & & & $\mathrm{a}$ & $\mathrm{a}$ \\
\hline Pithecops & & (a) & $\mathrm{a}$ & $\mathrm{a}$ & & & & \\
\hline Azanus & $\mathrm{b}$ & & & $\mathrm{a}$ & & $\mathrm{a}$ & & \\
\hline Everes & & (a) & $\mathrm{a}$ & $\mathrm{a}$ & $\mathrm{b}$ & $\mathrm{b}$ & $\mathrm{a}$ & \\
\hline Eicochrysops & $\mathrm{b}$ & & & & & & & \\
\hline Euchrysops & $\mathrm{c}$ & (a) & $\mathrm{a}$ & $\mathrm{a}$ & & & & \\
\hline Glaucopsyche & & & & & $\mathrm{a}$ & $\mathrm{c}$ & $\mathrm{b}$ & \\
\hline Lycaenopsis & & (a) & c & $\mathrm{c}$ & $\mathrm{b}$ & $\mathrm{a}$ & $\mathrm{a}$ & \\
\hline Polyommatus & $\mathrm{b}$ & (a) & $\mathrm{a}$ & $\mathrm{b}$ & $\mathrm{b}$ & $\mathrm{c}$ & $\mathrm{b}$ & $\mathrm{c}$ \\
\hline
\end{tabular}

The distribution of the sections of Polyommatini. $\quad \mathrm{a}=\mathrm{I}-4$ species, $\mathrm{b}=5^{-20}$ species, $\mathrm{c}=$ more than 20 species. In the case of the Australian Region, groups are placed in brackets when all the component species are thought to have arrived since the start of the Pleistocene Period and are confined to Queensland and/or Northern Territory. 
complex area which widely overlaps the S.E. Asian Subregion but at a higher average elevation. Its original centre probably lay in the area of S.E. Asia termed Cathaysia by du Toit (I937) and others. To-day it essentially comprises the upper basin of the Yangtse, but extends through the highlands of Yunnan, Indo-China and Burma and along the outer slopes of the Himalayas, with a few characteristic elements, such as Heliophorus (Lycaeninae) reaching, at a moderate elevation, as far east as Wallace's Line. The Palaearctic Region is clearly defined in its western half by the Sahara and the deserts of Central Asia, only a few African and Oriental species having invaded its southern fringes, but in its eastern half its boundary with the Sino-Himalayan Subregion is extremely blurred and in part altitudinal. The Australian Region includes the Cape York Peninsula, but I have placed in brackets those groups which in Australia are almost confined to Queensland and are likely to have arrived from the Oriental Region since the start of the Pleistocene Period.

The main factors affecting the dispersal of butterflies are availability of larval food plants (and ants in the case of the Lycaenidae) and the efficacy of different sorts of geographical barrier-climatic, water, desert. It would be easy to overemphasize the importance of larval food. Many Lycaenid larvae are polyphagous and in some cases the correct symbiotic ant appears to be of greater importance than the correct food plant (Bell, I9I5); adaptations to new food plants and ants are probably frequent in the long term. In theory climatic barriers should also be surmountable in the long term, but in the Lycaenidae only a few existing groups have a wide climatic tolerance, so that climate must have played an important part in restricting past dispersals. Water gaps and deserts have probably been of still greater importance, particularly the latter, since desiccation must be one of the greatest dangers faced by a travelling butterfly. To cross wide water or desert gaps butterflies should ideally be large and tough, like the Monarch Butterfly, Danaus plexippus (L.), or very small and light so that they can the more easily be passively transported by winds, especially those of tropical typhoon force. No Lycaenid species comes within the first category and it is probably significant that those whose distribution is most easily explicable by trans-ocean dispersal, such as Zizula, are all small. Rafting of the early stages might occur, but probably only over short and calm water gaps. Few Lycaenidae show any strong migratory tendency; a notable exception is Lampides boeticus (L.), which is widely distributed in Eurasia, Africa and Australia, but has not succeeded in spreading to the New World. However the occurrence of weakly separated Lycaenid genera in oceanic islands, such as Vaga in the Bonin and Hawaian Islands and Hypojamides in Tahiti, proves that Lycaenidae do succeed occasionally in crossing very wide ocean gaps in which intervening islands provide only widely-spread stepping stones. But the poverty of island faunas also proves that such dispersal must be very rare, so that it is unlikely to have played an important role in evolution. On the other hand it is clear that mass dispersal can take place across short water gaps, as proved by the post-Miocene invasion of the Papuan Subregion, further discussed below, by butterflies of evident S.E. Asian origin along island chains which have never been continuous land. But even in this case the persistent, though rather narrow, deep water gaps represented by Wallace's and Weber's Lines have clearly acted as checks to spread 
and to gene interaction, so that speciation has been able to proceed on a large scale on either side. I conclude that any marked climatic barriers or wide water or desert gaps must have had a decisive effect in determining the evolution of the Lycaenidae, but that narrower gaps and island chains will have had little influence at generic and higher levels.

Fortunately the reality of continental drift has at last received general acceptance. Its bearing on the evolution of the butterflies can, however, only be assessed realistically if the approximate time they evolved as a suborder is known. Forbes (I932) dated this as far back as the Jurassic. Zeuner (I960) suggested the mid-Cretaceous; this date does not appear to have been challenged by later workers and is adopted for my suggested reconstruction of the history of the Lycaenidae. At that date the world-wide dispersal of the marsupials indicates that there can have been no ocean barrier capable of preventing the dispersal of butterflies to all continents, though other barriers, particularly climatic ones, may well have existed. However the break-up of Gondwanaland and Laurasia was already far advanced. The final separation of Africa and South America, in the region of Liberia and northern Brazil, is dated by Tarling \& Tarling (I97I) to -92 million years. These authors state that at this date India and the still-joined continents of Australia and Antarctica had already broken away from Africa, the first two lying far to the south of their present latitudes, whilst North America had separated from all the other continents. N.W. Africa may still have had some connection with S.W. Europe, but the Tethys Ocean separated the rest of Africa, as well as the southern continents, from Eurasia by a gap which widened progressively eastwards.

Table $\mathrm{C}$ shows that the Lycaenidae exist to-day in the greatest abundance and variety in the S.E. Asian Subregion of the Oriental Region, with Africa lagging only a little behind. The greater variety in the former may be due in part to its more complex geological history. In both regions the greatest wealth of species occurs in the tropical rain forest areas. The Lycaenidae are very poorly represented, in terms of the number of subfamilies, tribes and sections, in both Americas and, as will be shown later, their present Lycaenid fauna is clearly derived from the Old World. On the other hand the Riodinidae are extremely abundant and varied in the Neotropical Region, but are rather poorly represented in the Oriental Region, still more so in the Palaearctic and Ethiopian Regions and are absent from the Australian Region (sensu stricto). This distribution strongly suggests that the Lycaenoidea originated in the tropical areas of Gondwanaland and that the separation of South America from Africa resulted in the fundamental division of the superfamily into Riodinidae and Lycaenidae respectively. However this suggestion needs some qualification. The Lycaenid subfamilies Curetinae, Poritiinae and Lipteninae each share some separate characters with different groups within Riodinidae, especially in certain features of the male genitalia ( $\mathrm{I}$ am indebted to Clench (in litt.) for drawing my attention to common features found in Lipteninae and some Neotropical Riodinidae). This suggests that all Riodinidae may not be descended from one single ancestor and all Lycaenidae from another; but rather that the evolution of Lycaenoidea may have proceeded far enough, before the break-up of Gondwanaland, for the superfamily tree to have begun to put out branches. These 
incipient branches, whose species would be barely separated from the original Lycaenoid ancestor, may have given rise to Riodinid groups in the New World and to Lycaenid groups in the Old, their distinctive family characters, such as the strongly atrophied male fore tarsus and grooved antenna of Riodinidae compared with the comparatively weakly degenerate fore tarsus and ungrooved antenna of Lycaenidae, having evolved subsequently by convergence in the New and Old World respectively. If this should becorrect, then the fundamental division into Lycaenidaeand Riodinidae, though convenient for taxonomic purposes, would reflect a false phylogenetic history.

Within the Old World the ancestral Lycaenid stock must have spread quickly from Africa into Eurasia without meeting any climatic check, since at that time S.W. Europe lay much further to the south than today and had a tropical climate. On the other hand it is not at all likely that this stock could have reached India, Australia or Antarctica because of the water and climatic barriers, even allowing for the fact that world climates were more equable than to-day. Subsequently the northward drift of Africa and western Eurasia, the climatic deterioration which apparently set in during the Tertiary, the development of the Sahara and the continuing barrier of Tethys must have led to the progressive isolation of the African Lycaenid fauna from that of Eurasia. Groups confined to tropical rain forest would have been isolated first, giving rise to such branchings as the Poritiinae in Eurasia and the Lipteninae in Africa. Other groups may have maintained intermittent contact for longer periods, but the individuality of much of the African Lycaenid fauna suggests isolation over a long period. Finally, India's northward drift, culminating in fusion with Eurasia during the Pliocene, reopened a route between Africa and S.E. Asia and allowed some interchange of their fauna. My impression, further discussed later, is that movement was mainly from Africa to Asia, and this movement is continuing to-day, though necessarily now confined to xerophile genera such as Azanus.

Within Eurasia the rotational movement which gave rise to the northward drift of western Europe and the accompanying climatic deterioration must have progressively forced into S.E. Asia all those groups which could not adapt to colder and drier conditions. Furthermore, an arm of Tethys extending broadly northward across Central Asia may have partially and intermittently subdivided the continent and given rise to separate eastern and western centres of development. Among the groups which became adapted to a temperate climate the Theclini, Heliophorus section of Lycaeninae and the Everes section of Polyommatini probably developed in the east and the Tomarini in the west, whilst the Lycaena section of Lycaeninae and the Polyommatus and Glaucopsyche sections of Polyommatini were probably more northern and holocontinental. I doubt whether the Pleistocene glaciations had much effect on the composition and distribution of the Palaearctic Lycaenidae at the generic level, but in the western part of the region the restriction of the fauna to separated refuge areas during the cold phases must have helped greatly to accelerate speciation.

As I have already stated, I think it unlikely that India had a Lycaenid fauna until its northward drift brought it close to, or even into contact with, Eurasia. This view agrees generally with that of Holloway (I969), who considered that the 
whole of its present butterfly fauna can be attributed to recent colonisation, mainly from S.E. Asia. Peninsular India has no endemic Lycaenid genera except the monobasic Rathinda and Zesius. Rathinda is only doubtfully distinct from the Oriental genus Horaga and is clearly derived from it. The case of Zesius is more interesting; its nearest relative is the Australian Jalmenus, and at first sight it is tempting to suppose that these may be two relict genera descended from a common Gondwanan ancestor. However, neither genus, in any of their characters, suggests a particularly ancient origin and I think it far more likely that both are descended from a common Oriental Miocene or post-Miocene ancestor whose descendants have died out in intervening areas. I possibly differ from Holloway in thinking that many of the present Lycaenidae of S.E. Asia are not old endemics but are derived from African invasions which came in across India in post-Miocene times and thereafter underwent secondary development in India as well as in Sundaland and in the Sino-Himalayan Subregion. The largest of these supposed African immigrant groups are the Thecline tribes Iolaini and Aphnaeini. The large majority of the Oriental members of both these tribes differ but little from their African relatives, so that long isolation seems out of the question. Moreover I think it highly significant that no member of either tribe has succeeded in crossing Weber's Line, despite being strong insects with considerable powers of dispersal, whereas the majority of the undoubtedly endemic S.E. Asian groups such as the Curetinae, the Thecline tribes Arhopalini, Horagini, Catapaecilmatini and many sections, such as Nacaduba and Jamides, of the comparatively weak-flying Polyommatini have reached the Papuan Subregion. Had the Iolaini and Aphnaeini been present in S.E. Asia in late Miocene times, when the Melanesian Arc started to emerge, I think it certain that they would be represented in the Papuan fauna to-day. Other groups and genera represented in S.E. Asia to-day, which I suspect are similarly derived from Africa, even though some of their component species have reached Australia, include Spalgini, Lycaenesthini and the Oriental species of the Leptotes, Castalius, Azanus and Euchrysops sections of Polyommatini.

The zoogeography of the Indo-Australian butterflies has bee discussed by Holloway \& Jardine (I968). They stated that there was evidence of extensive land connections between Australia and Asia in the late Cretaceous, when there was a more uniform climate, fauna and flora throughout, and dated the arrival from Asia of the endemic Australian butterflies to the early Tertiary. However, in a later paper Holloway (I970) points out that recent work on sea floor spreading and continental drift has shown that these Asian connections probably did not exist and that Australia, after splitting from Antartica in the early Tertiary, was isolated from all other land areas until its slow northward drift brought it into proximity with Papua during the late Pliocene. He suggests that some of the autochthonous butterflies, such as the Satyrid tribe Hypocistini, may have entered Australia from South America via Antarctica at the start of the Tertiary. Whatever the position may be in other butterfly families or insect orders, ${ }^{9}$ a South American origin for

\footnotetext{
${ }^{9}$ In the case of the older established insect orders there is a marked similarity between the faunas of Australia, New Zealand and Chile (Riek, I970).
} 
any of the Australian Lycaenidae is out of the question and it is necessary to search for an alternative explanation for the evolution of the Australian 'endemics'. Solely on the basis of present distribution the group having the best claim to be of Australian origin is the Thecline tribe Ogyrini, which is almost confined to Australia proper, only two or three species occurring in New Guinea. Other possible endemics are the Candalidini and Luciini. Of the eight described genera in Candalidini six monobasic or small genera are confined to Australia, whilst in a seventh, Erina, one species has spread outside Australia to Sumba and New Guinea. The eighth genus, 'Holochila' sensu auctt., is a large omnibus genus containing four speciesgroups each probably of at least subgeneric worth. The two smallest groups are as strongly represented in Australia as in New Guinea, whilst the other two have many more species in New Guinea; but as no species of 'Holochila' has been found in the Moluccas, Bismarcks or Solomons this preponderance of New Guinea species could be attributed to secondary, explosive development in New Guinea in late Pliocene times when the single large island of to-day may have consisted of several smaller land areas. In the case of Luciini, the Lucia section is almost confined to Australia and may have evolved there; the more numerous Hypochrysops section, although quite well represented in Australia, is much more strongly represented in the Papuan Subregion, with representatives in all the outlying island groups (one species, Hypochrysops coelisparsus (Butler), has even reached continental Asia.) I think that the most likely explanation for the origin of all these groups lies in the belief of Zeuner (I943) and others that there was land a little to the north of the present position of New Guinea connected to Asia by island stepping stones at the start of the Tertiary. The ancestors of these groups may have reached this 'protoPapua' from Asia at this time and become isolated there by the development of the deep geosyncline which submerged all the stepping stones. It is thought that the proto-Papua remained in existence until the mid-Miocene, when the present mountain ranges of New Guinea and the Melanesian Arc which connects them to S.E. Asia began to emerge. If the proto-Papua and the newly emergent New Guinea co-existed for a short time the butterfly fauna could have transferred from the one to the other and later on spread to Australia where, in the absence of competition, some explosive evolution may have taken place in the last few million years.

To-day's Papuan Lycaenid fauna, except in so far as ancient endemic elements may have survived in the area during the earth movements of the Miocene, as postulated above, must date from the raising of the Melanesian Arc, to be followed by the emergence of the Inner and Outer Banda Arcs. These routes would have allowed progressive invasion of Papua, and thence of Australia, by S.E. Asian elements. Amongst these Miocene and later arrivals in Papua, the ancestors of Callictita (Polyommatini) must have derived from stocks more widespread at that time but to-day surviving only in Africa in distantly related forms. Other characteristic Papuan groups, such as the Danis section of Polyommatini, probably evolved explosively in Papua from ancestors no longer identifiable or extinct in other areas. During the low sea levels of the Pleistocene the invasion of S.E. Asian butterflies must have continued at an increased rate, and many species confined in Australia to 
N.E. Queensland must have arrived during this period. The reverse radiation of Papuan butterflies towards Asia has evidently been on a much smaller scale.

The most interesting and unexpected invaders of the Australian Region are the 'Coppers' (Lycaena section of Lycaeninae) to-day confined to New Zealand. It seems impossible to suppose that these have been long isolated since they show only slight differences, both in facies and male genitalia, from their Holarctic relatives. They possibly reached New Zealand during a low sea level phase of the Pleistocene when world climates were colder. They must, in any case, have crossed enormous water gaps, and the genus Lycaena (sensu lato) must at that time have had a wider distribution. To-day no Coppers survive nearer than the Himalayas unless, conceivably, some species linger undetected in the mountains of New Guinea or New Caledonia. ${ }^{10}$

I have already stated that the Lycaenid fauna of the New World is derived from the Old. This needs some further justification. Much the most abundant and characteristic New World group, both in North and South America, is the Thecline tribe Eumaeini. Because of the similarity of the male genitalia, of the arrangement of the hindwing tails and, to a lesser extent, of the androconial scent scales, this tribe must share a common ancestry with the Deudorigini and Tomarini of the Old World. All the Old World species, with the single exception of the monobasic Sithon, have eleven forewing veins, whilst every species of Eumaeini has only ten, suggesting that ten forewing veins were an ancestral character of the latter tribe. It is not possible to conceive that the Eumaeini gave rise to the Old World groups, since this would involve the reacquisition by the latter of a lost vein, and therefore the common ancestor of the three groups must have lived in the Old World. When and where the Eumaeini first developed can only be speculated upon. They are most abundant and varied in South America, suggesting that the original ancestor lived there, possibly having come in from Africa across the Atlantic early in the Tertiary at a time when the Atlantic gap was much narrower. Thence they could have radiated to North America by a further trans-ocean spread, or overland across the temporary isthmian land connection which Tarling \& Tarling (I97I) state existed some thirty to forty million years ago (but most authors, e.g. Darlington, I965) seem to hold the view that South America was completely isolated from North America throughout the whole Tertiary until the present isthmian connection was established some three to four million years ago). Alternatively the original ancestor may have entered North America first via the Bering route, but I think this is much less likely. In any case the tribe shows so much diversity as to suggest that simultaneous development continued in both North and South America for a very long time, probably with regular interchange across the comparatively narrow water gap separating the two continents, culminating in the mass exchange which must have taken place when the present land connection was established. In addition, at a late stage in the tribal development (? Upper Pliocene onwards),

\footnotetext{
${ }^{10} \mathrm{Dr}$ Sibatani (pers. comm.) has told me that he has discovered, in the highlands of New Guinea, between $85^{\circ 0^{\prime}}$ and $950^{\prime}$, the existence of an apparently new genus of Lycaeninae containing at least two species, which, in appearance, recalls the Neotropical genus Iophanus. I am grateful to Dr Sibatani for allowing me to give advance notice of his very interesting discovery.
} 
many species adapted to a temperate or cold environment crossed into Eurasia by the Bering route, probably during a period of mutual interchange which brought into North America from Asia the Lycaeninae, the ancestors of the Thecline genera Hypaurotis and Habrodais and the Polyommatus (part), Glaucopsyche, Everes and Lycaenopsis sections of the Polyommatini. The present Eurasian species of Eumaeini show very slight differences from their Nearctic relatives, and the tribe has been present in the Old World for too short a time to adapt to a tropical climate or to spread outside the Palaearctic Region and the Sino-Himalayan Subregion of the Oriental Region.

The other major endemic New World group comprises that part of the Polyommatus section containing Hemiargus and related Neotropical and Sonoran genera. These are more specialized than the Old World genera, having acquired the bizarre character of a sagum. This character cannot, I think, have evolved in the short period elapsing since the supposed late Pliocene Eurasian/American interchange, and I think the original ancestor of this group of genera probably reached the New World as early as the mid-Tertiary. As most of the component species are adapted to a temperate climate, it is more likely that the ancestral stock entered via the Bering route than across the Atlantic. Of the remaining New World groups, Feniseca (Spalgini) and Brephidium, Leptotes and Zizula (Polyommatini) may have arrived by waif dispersal across the Atlantic from Africa, a method already suggested by Clench (1963) for Brephidium and Leptotes, though he thinks the Bering route a more likely alternative for Zizula. As Feniseca is quite strongly differentiated from its nearest African relatives, I think its arrival in the New World must have occurred a very long time ago, perhaps not later than the mid-Tertiary. The American species of Brephidium are less strongly differentiated, but apart from some genitalic differences their androconial scent scales are quite distinct, so that their arrival can hardly have been very recent. The other two genera probably arrived much later.

\section{REFERENCES}

Aurivillius, C. I9I4. In Seitz, A., Gross-Schmetterlinge der Erde (2); Exotische Fauna 13. Africanischen Tagfalter (1908-1925). 613 pp., 8o pls. Stuttgart.

Bell, T. R. I915-1920. The common butterflies of the Plains of India, Parts 17-25. J. Bombay nat. Hist. Soc. $23: 48$ I-497; idem, $24: 656-672 ;$ idem, $25: 430-453 ; 636-664$; idem, $26:$ 98-140, 438-487, 750-769, 94I-954; idem, $27: 26-32$.

Bethune-Baker, G. T. I9Io. A revision of the African species of the Lycaenesthes group of Lycaenidae. Trans. ent. Soc. Lond. 1910 : I-84, I3 pls.

1918. A revision of the genus Tarucus. Trans. ent. Soc. Lond. 1918 : 269-296, 7 pls.

1925. A revision of the Liphyrinae, together with a description of the puparium of Liphyra brassolis and of the pupae of Aslanga vininga and A. lamborni (Lepidoptera). Trans. ent. Soc. Lond. 1925 : 199-238, 24 pls.

Bingham, C. T. I907. Fauna of British India. (Ist Ed.); Butterflies 2. viii +480 pp., Io pls., I04 figs. London.

Cantlie, K. I963. The Lycaenidae portion (except the Arhopala group) of Brigadier Evans' The Identification of Indian Butterflies 1932 (India, Pakistan, Ceylon, Burma). I56 pp., 5 pls. Bombay. 
Clark, G. C. \& Dickson, C. G. C. I956a. Proposed classification of the S. African Lycaenidae from the early stages. J. ent. Soc. Sth. Afr. $19:$ r95-2I5.

1956b. The honey gland and tubercles of larvae of the Lycaenidae. Lepid. News 10 : $37-40,3$ pls.

1960. The life histories of two species of Thestor (Lepidopt.: Lycaenidae). J. ent. Soc. Sth. Afr. $23: 278-283,2$ pls.

- 1971. Life Histories of the South African Lycaenid Butterflies. xvi +272 pp., 125 pls. Cape Town.

Clench, H. K. I955. Revised classification of the butterfly family Lycaenidae and its allies. Ann. Carneg. Mus. 33 : 26I-275.

1963. A synopsis of the West Indian Lycaenidae, with remarks on their zoogeography. J. Res. Lepid. 2 (4) : 247-270, 2 pls.

- 1965. In Fox, Lindsey, Clench \& Miller. The Butterflies of Liberia. Mem. Am. ent. Soc. $19.2+43^{8}$ pp., 233 figs, 3 maps, 2 graphs.

Chapman, T. A. I9Io. On Zizeeria (Chapman), Zizera (Moore), a group of Lycaenid butterflies. Trans. ent. Soc. Lond. 1910 : 479-497, ro pls.

Corbet, A. S. I939. A revision of the Malayan species of Allotinus Felder \& Felder. Trans. R. ent. Soc. Lond. $89: 63-77$, I pl., 23 figs.

Courvoisier, L. G. i9i6. Über Männschenschuppen bei Lycaeniden. Verh. naturf. Ges. Basel 26 : I I-48, 2 pls.

Cowan, C. F. I966a. Indo-Oriental Horagini (Lepidoptera: Lycaenidae). Bull. Br. Mus. nat. Hist. (Ent.) 18 (4) : ro3-I4I, 3 pls.

— 1966b. The generic name Marmessus Hübner. Ann. Mag. nat. Hist. (13) 9: 4I 7-4r8. 1968. Annotationes Rhopalocerologicae. 20 pp. Berkhamsted.

- 1970. Annotationes Rhopalocerologicae i970. 70 pp. Berkhamsted.

Darlington, P. J. JR. I965. Biogeography of the southern end of the World. vii + 236 pp., 38 figs. Cambridge, Mass.

Distant, W. L. I882-I886. Rhopalocera Malayana. I6 +482 pp., 44 pls. London and Penang.

Doherty, W. 1886. A list of butterflies taken in Kumaon. J. Asiat. Soc. Beng. 55 : 103-140.

— I889. On certain Lycaenidae from Lower Tenasserim. J. Asiat. Soc. Beng. 58 : 409-440, 2 pls.

Doubleday, E. 1847. List of the Specimens of Lepidopterous Insects in the Collection of the British Museum (2). $2+57$ pp. London.

Ehrlich, P. R. I958. The comparative morphology, phylogeny and higher classification of the butterflies. (Lepidoptera: Papilionoidea). Kans. Univ. Sci. Bull. 39 (8) : 305-370.

- 1960. A note on the systematic position of the giant Lycaenid butterfly Liphyra brassolis Westwood. Pan-Pacif. Ent. 36 : 133-135.

Eliot, J. N. 1969. An analysis of the Eurasian and Australian Neptini (Lepidoptera: Nymphalidae). Bull. Br. Mus. nat. Hist. (Ent.) Suppl. $15 . \quad$ I 55 pp., 3 pls, Ior figs.

Evans, W. H. 1932. The Identification of Indian Butterflies, 2nd ed. ro +454 pp., 32 pls. Madras.

FarQuharson, C. O. et al. 1922. Five years observations (1914-1918) on the bionomics of southern Nigerian insects, chiefly directed to the investigation of Lycaenid life histories and to the relation of Lycaenidae, Diptera and other insects to ants. Trans. ent. Soc. Lond. 1921 : 319-53I, I9 pls, 6 figs.

Forbes, W. T. M. I932. How old are the Lepidoptera? Am. Nat. $66: 452-460$.

- 1957. The Lycaenid antenna. Lepid. News 11 : 15-16.

Ford, E. B. 1955. Moths. $19+266$ pp., 56 pls, 7 figs, 12 maps. London.

Fruhstorfer, H. r9i6. Ein neues Organ bei den Gerydinae (Lycaenidae). Societas ent. $31: 2$.

1924. In Seitz, A., Gross-Schmetterlinge der Erde (2); Exotische Fauna 9. Indo-Australischen Tagfalter (1908-1927). Ir97 pp., I77 pls. Stuttgart. 
Gressitt, J. L. 1956. Some distribution patterns of Pacific Island Fauna. Syst. Zool. 5 : II -32 .

HaAse, E. I888. Duftapparate indo-australischen Schmetterlinge (3). Dt. ent. Z. Iris 1 : $28 \mathrm{I}-336$.

Hemming, F. 1967. The generic names of the butterflies and their type-species. Bull. Br. Mus. nat. Hist. (Ent.) Suppl. 9. 509 pp.

Holloway, J. D. 1969. A numerical investigation of the biogeography of the butterfly fauna of India, and its relation to continental drift. Biol. J. Linn. Soc. 1: 373-385, I fig. - 1970. The biogeographical analysis of a transect sample of the moth fauna of Mr. Kinabalu, Sabah, using numerical methods. Biol. J. Linn. Soc. 2 : 259-286, 2 pls, 7 figs.

Holloway, J. D. \& Jardine, N. I968. Two approaches to zoogeography: a study based on the distribution of butterflies, birds and bats in the Indo-Australian area. Proc. Linn. Soc. Lond. 179 : 153-188, 2 I figs.

Howarth, T. G. I957. A revision of the genus Neozephyrus Sibatani \& Ito (Lepidoptera: Lycaenidae). Bull. Br. Mus. nat. Hist. (Ent.) 5 (6) : 233-272, I05 figs.

Jackson, T. H. E. I937. The early stages of some African Lycaenidae. Trans. R. ent. Soc. Lond. 86 : 20I-238.

Janse, A. J. T. I932. The moths of South Africa 1. II +376 pp., I5 pls, I30 figs. Durban.

Jordan, K. I898. Contributions to the morphology of Lepidoptera. Novit. zool. 5: 374-4I5, 73 figs.

Kershaw, J. C. 1907. Butterflies of Hong Kong and South-east China. ${ }_{5} 6$ pp., 2 I pls, 4 figs. Hong Kong.

LAMBORN, W. A. I9I4. On the relationship between certain West African insects, especially ants, Lycaenidae and Homoptera. Trans. ent. Soc. Lond. $1914: 436-524,4$ pls.

LeAch, W. E. I8I5. In Brewster, D., The Edinburgh Encyclopaedia 9. $2+766$ pp. Edinburgh.

Mayr, E. I963. Animal species and Evolution. I4 +797 pp., 65 figs. 43 tables. Cambridge, Mass.

Miller, L. D. 1968. The higher classification, phylogeny and zoogeography of the Satyridae (Lepidoptera). Mem. Am. ent. Soc. 24. I 74 pp., 327 figs, 7 tables.

Morrell, R. I956. Notes on the life histories of a number of butterflies of the subfamily Theclinae (Lycaenidae). Malay Nat. J. 10 : ro4-108, 3 pls, 2 figs.

Munroe, E. I96r. The Classification of the Papilionidae (Lepidoptera). Can. Ent. Suppl. 17. $5 \mathrm{I} \mathrm{pp}$.

Murray, D. I. I935. South African Butterflies, a Monograph of the family Lycaenidae. 195 pp., I7 pls. London.

Nabokov, V. I945. Notes on Neotropical Plebejinae (Lycaenidae: Lepidoptera). Psyche, Camb. 52 : I-6I, 8 pls.

Nicéville, L. DE. I89o. The Butterflies of India, Burmah and Ceylon 3. xi +503 pp., 6 pls. Calcutta.

- I9oo. The food-plants of the butterflies of the Kanara District of the Bombay Presidency, with a revision of the butterflies there occurring. J. Asiat. Soc. Beng. 69 : 187-277.

Reuter, E. I897. Über die Palpen der Rhopaloceren. Acta Soc. Sci. fenn. 22 (I). xvi + 588 pp., 6 pls.

Riek, E. F. I970. Endemism in the Australian Insect Fauna. Proc. R. ent. Soc. Lond. (C) 35 (5) : 17 .

Riley, N. D. I956. The genera of Holarctic Theclinae: a tentative revision. Proc. Ioth Int. Congr. Ent. 1 : 28I-288.

Röber, J. I892. In Staudinger, O. \& Schatz, E., Exotische Schmetterlinge 2; die Familien und Gattungen der Tagfalter. 284 pp., 50 pls. Fürth.

Rosier, J. P. I95I. Metamorphosis of some Javanese butterflies (2). Idea 9 : 26.

Schwanwitsch, B. N. I949. Evolution of the wing pattern in the Lycaenid Lepidoptera. Proc. zool. Soc. Lond. 119 : 189-263. 
Sellier, R. I97i $a$. Données sur les apports de la microscopie électronique à balayage, pour l'étude ultrastructurale des écailes alaires chez les lépidoptères diurnes. C. R. Acad. Sc. Paris (Série D) 273 : 2097-2100, 4 pls.

I97 $b$. Etude morphologique en microscopie électronique à balayage de quelques types d'androconies chez les lépidoptères diurnes. Idem, $273: 255^{0-2553, ~} 4$ pls.

Shirôzu, T. I962. Study of immature stages and foodplants. J. Lepid. Soc. $15: 245^{-24} 8$

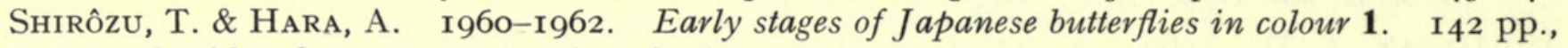
6o pls; idem 2. 139 pp., 60 pls. Osaka.

Shirôzu, T. \& Yамамото, H. I956. A generic revision and the phylogeny of the tribe Theclini (Lepidoptera: Lycaenidae). Sieboldia $1: 329-42 \mathrm{I}, 5 \mathrm{I}$ pls.

\& — 1957. Systematic position of the genus Curetis (Lepidoptera: Rhopalocera). Sieboldia $2: 43^{-5}$ I, 15 figs.

Stempffer, H. I957. Les lépidoptères de l'Afrique noire francaise (3) : Lycaenides. Init. afr. $14:$ I-228, 33I figs.

1967. The genera of the African Lycaenidae (Lepidoptera: Rhopalocera). Bull. Br. Mus. nat. Hist. (Ent.) Suppl. 10. 322 pp., I pl., 348 figs.

Swainson, W. 1827. A sketch of the natural affinities of the Lepidoptera diurna of Latreille. Phil. Mag. (2) 1 (3) : I80-I88.

1831-1832. Zoological Illustrations, or original figures and descriptions of new, rare, or interesting animals... (2) 2, pls 46-9I. London.

Swinhoe, C. r9io-i9i2. Lepidoptera Indica 8. ix +293 pp., 67 pls. Idem 9. $8+278$ pp., 5 I pls. London.

Tarling, D. H. \& Tarling, M. P. I97I. Continental Drift. 1 I 2 pp., 4 pls, 43 figs. London.

Tite, G. E. I963. A revision of the genus Candalides and allied genera. Bull. Br. Mus. nat. Hist. (Ent.) 14 (5) : I99-259. 4 pls, I I9 figs.

TorT, A. L. DU. I937. Our wandering continents. I3 +366 pp., 48 figs. Edinburgh.

Toxopeus, L. J. I929. De Riodinidae en Lycaenidae van het eiland Java. Tijdschr. Ent. 72 : $215^{-244}$.

Tutt, J. W. 1907-1908. Natural History of British Butterflies. 2. x, 495 pp., 28 pls. London.

VARLey, G. C. 1962. A Plea for a New Look at Lepidoptera with Special Reference to the Scent Distributing Organs of Male Moths. Trans. Soc. Br. Ent. 15 (3) : 29-40, 2 figs.

Waterhouse, G. A. 1932. What Butterfly is that? 29I pp., 34 pls. Sydney.

Waterhouse, G. A. \& Lyell, G. I914. The Butterflies of Australia. 238 pp., 888 figs. Sydney.

Warren, B. C. S. I947. Some Principles of Classification in Lepidoptera, with special Reference to the Butterflies. Entomologist 80 : 208-2I7, 235-24I, 262-268, 280-282.

Zeuner, F. E. 1943. Studies in the Systematics of Troides Hübner (Lepidoptera: Papilionidae) and its Allies; Distribution and Phylogeny in Relation to the Geological History of the Australasian Archipelago. Trans. zool. Soc. Lond. 25 (3) : 107-184, I 5 figs.

1946. Dating the Past. I $8+444$ pp., 24 pls, Io3 figs. London.

1960. Notes on the evolution of the Rhopalocera. Proc. IIth Int. Congr. Ent.: 3Io-3II. 
All the scanning electron micrographs were taken by Mr R. I. Vane-Wright, other than Pl. 4, fig. I9, taken by Mr B. S. Martin, from a specimen prepared by Miss Penny Duttson. The plates were prepared by Mr R. L. Smiles, from prints made by Mr Roger Freeman. The published micrographs represent only a small part of those taken; for the convenience of later workers the negatives permanently stored in Electron Microscope Unit of the British (Museum (Natural History) are listed below:

Species

Anthene liodes

Catapaecilma major

Creon cleobis

Cyprotides cyprotus

Freyeria trochylus

Hereitsonia boisduvalii

Hypolycaena liara

Liptena tullia

Miletus chinensis

Niphanda tessellata

Polyommatus icarus

Rapala iarbas

Thecla bitias
Negative numbers

$\mathrm{E} 7 / 342-356$

E7/357-36I; E8/2I5-225

E7/I55-I72; E8/226-227; E8/24I-245, 247-248

E9/232; E9/266-267

E7/338-34I(ㅇ); E8/249-25I (ฮึ)

E7/I77-I89

E9/I2I-I23

$\mathrm{E} 9 / 225-227$

$\mathrm{E}_{5} / 624-634$

$\mathrm{E} 8 / 252-254 ; \mathrm{E} 8 / 265-268$

$\mathrm{E} 8 / 2 \mathrm{II}-2 \mathrm{I} 4 ; \mathrm{E} 8 / 264 ; \mathrm{E} 9 / 260-265$

E5/635-645

$\mathrm{E} 8 / 255-263$

The text-figures are drawn freehand, and no claim is made to great accuracy or artistic merit. For the purpose of this work neither is needed, in the case of the male genitalia the aim being merely to show the general pattern. Magnification is not constant, some genitalia diagrams having been drawn for convenience at a relatively high or low magnification, but the figures of scales (Text-figs I22-I62) are roughly at the same magnification. In nearly all cases only the nearer half of the genitalia has been drawn, but in a few cases (e.g. Text-fig. 6) the complete armature has been drawn; in such cases the more distant half of the armature is drawn in thinner lines. The following abbreviations have been used:-

$$
\begin{aligned}
& \mathrm{a}=\text { alula } \\
& \mathrm{b}=\text { brachium } \\
& \mathrm{ba}=\text { basal arm } \\
& \mathrm{c}=\text { coecum } \\
& \mathrm{ca}=\text { costal arm } \\
& \mathrm{cor}=\text { cornutus } \\
& \mathrm{cp}=\text { Chapman's process } \\
& \mathrm{cpl}=\text { central plate } \\
& \mathrm{crs}=\text { crescent-shaped sclerite } \\
& \mathrm{di}=\text { diaphragma } \\
& \mathrm{du}=\text { ductus seminalis } \\
& \mathrm{f}=\text { flail }
\end{aligned}
$$


hs $=$ hood-like structure

j $=$ juxta

$1=$ labile

lpt $=$ lateral process of tegumen

lr $=$ lateral ridge

$\mathrm{lw}=$ lateral window

$\mathrm{p}=$ penis

pd = point at which lobes of uncus, valvae, or saccus divide

ped $=$ pedicel

sa $=$ saccus

sag = sagum

$\mathrm{sb}=$ sclerotized band

$\mathrm{sbz}=$ subzonal portion of penis

sc $=$ scaphium

sh = sheath

sl $=$ sacculus

$\mathrm{sp}=$ special process

$\mathrm{spz}=$ suprazonal portion of penis

ss $=$ subscaphium

sus $=$ suspensorium

$\mathrm{t}=$ tubercle

$\mathrm{tm}=$ transverse membrane

trs $=$ transtilla

tsh $=$ tergal-sternal hinge

$\mathrm{v}=$ valva

vi $=$ vinculum

$\mathrm{ul}=$ lobes of uncus

$\mathrm{x}=\mathrm{X}$-piece

$\mathrm{z}=$ zone

${ }^{11}$ Since completing Text-fig. I I have changed my views concerning the status of Aphnaeini, and consider that this tribe must rank as a major division of Theclinae, approximately coequal in status to all the other tribes lumped together. My reasons are:-

a) The musculature of the male genitalia differs from that of the remainder of the subfamily, which shares a common pattern with Lycaeninae and Polyommatinae (Sibatani, pers. comm.).

b) As well as the distinctive features of the early stages, already discussed (p. 4I2), it is apparent that the head of the adult larva is comparatively large and, usually, not, or only a little, retracted (Clark \& Dickson, I971 : pls. 75-94).

c) Alone in Theclinae all twelve fore wing veins are frequently present in both sexes.

d) The exceptionally prominent endodont in the tarsal claw. 


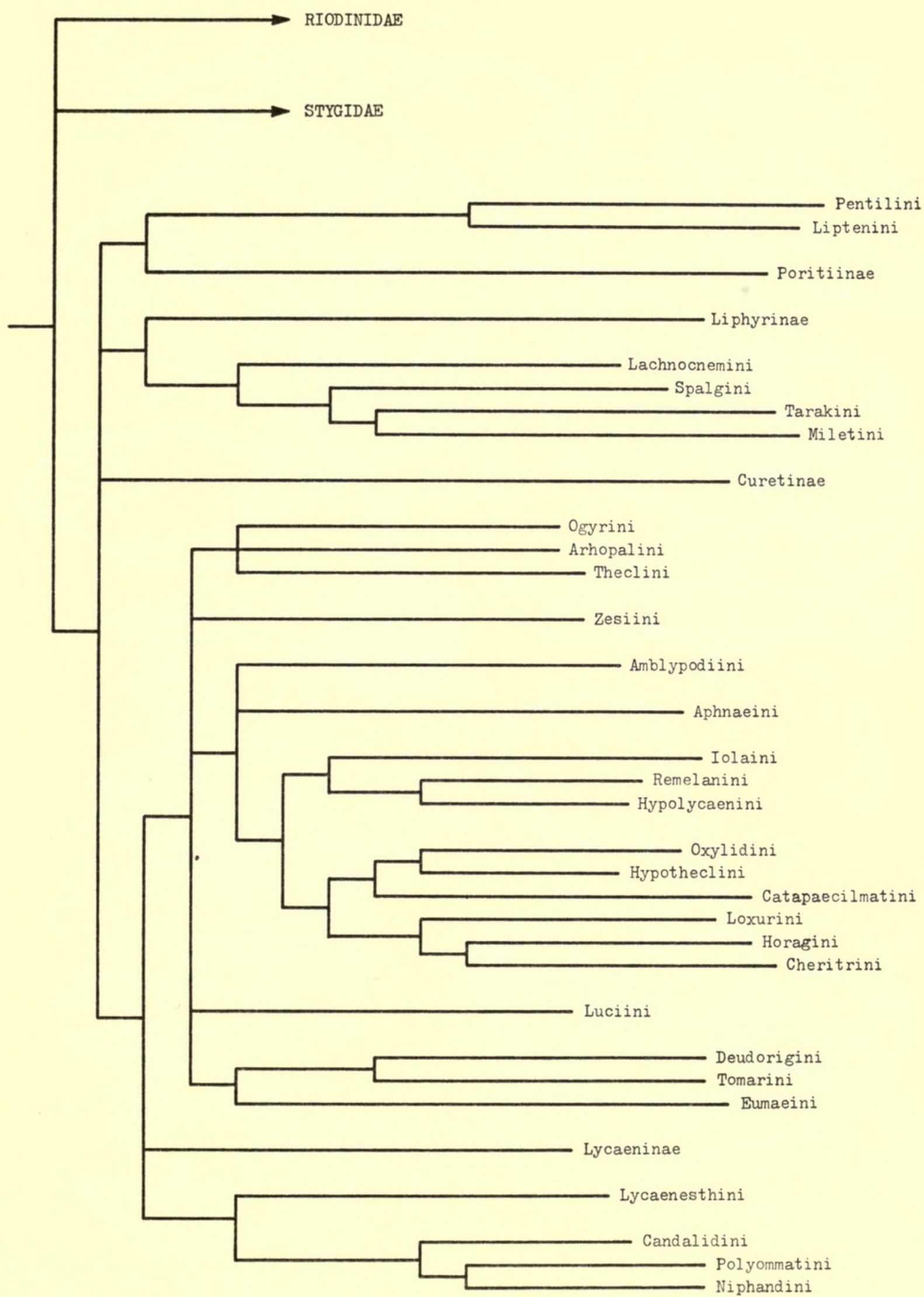

Fig. I. The phylogeny of the Lycaenidae. The extent of the horizontal lines towards the right indicates the approximate degree of specialization. ${ }^{11}$ 

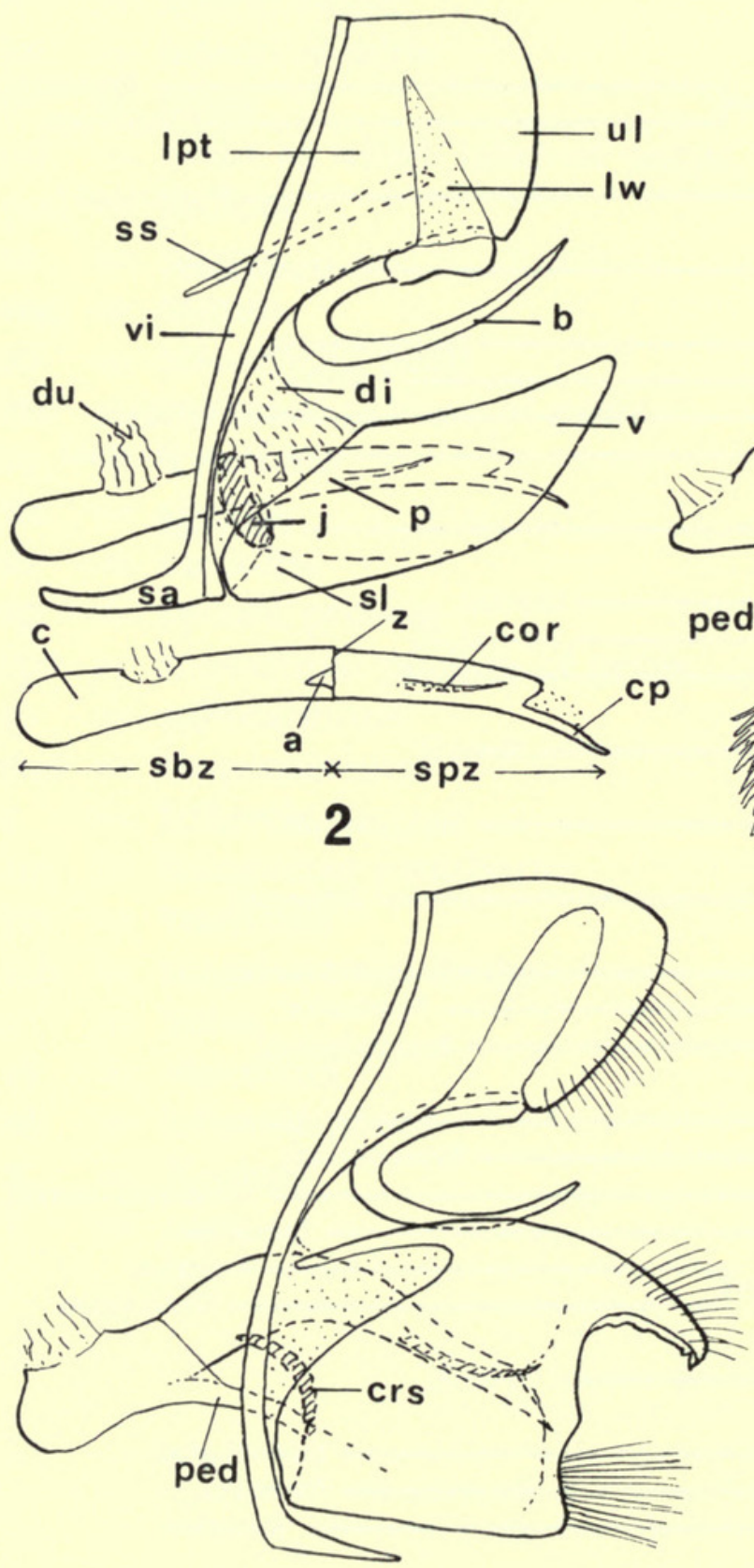

4

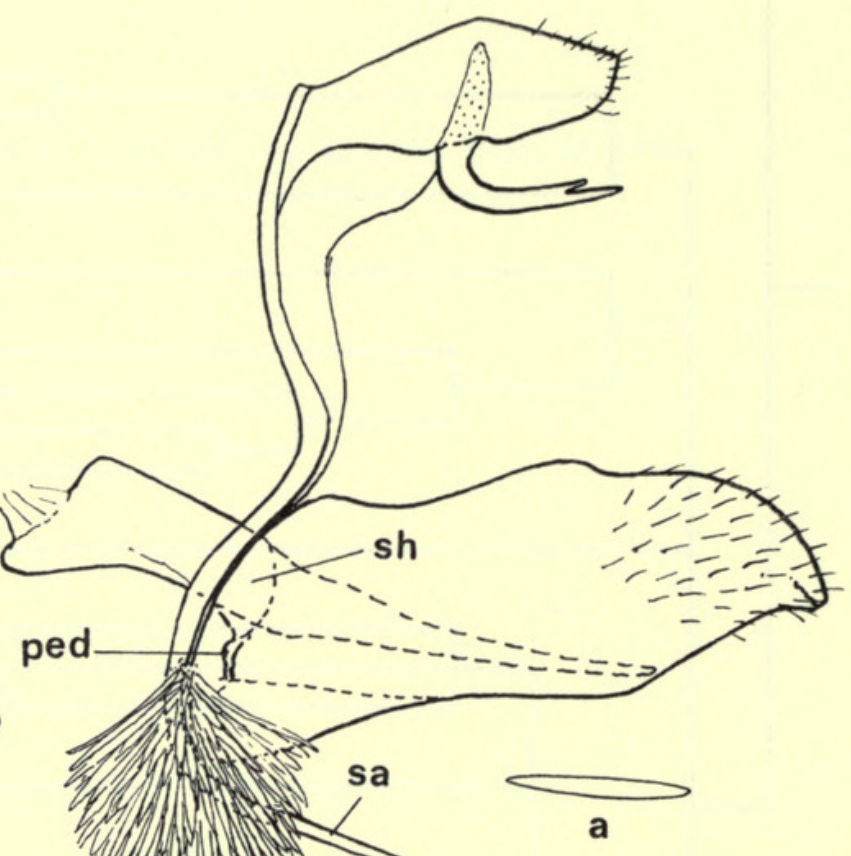

3

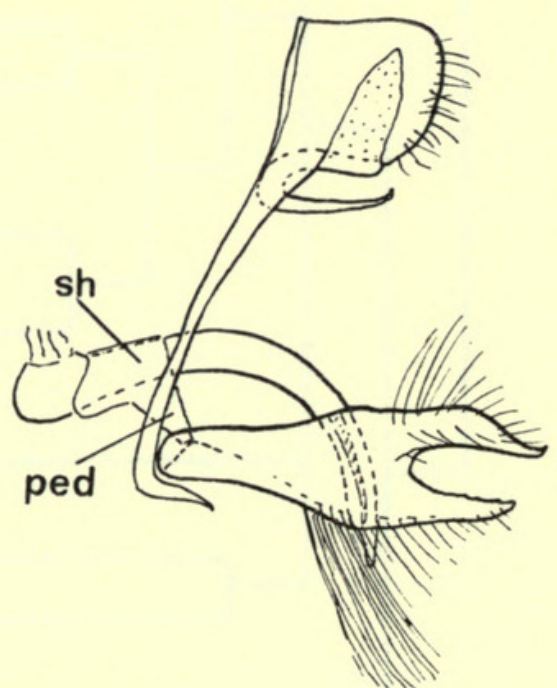

5

Figs 2-5. Male genitalia. 2. Notional species to illustrate most of the terms used for the components of the male genitalia. 3. Liptena despecta (Holland). 4. Deramas livens Distant. 5. Cyaniriodes libna (Hewitson). 


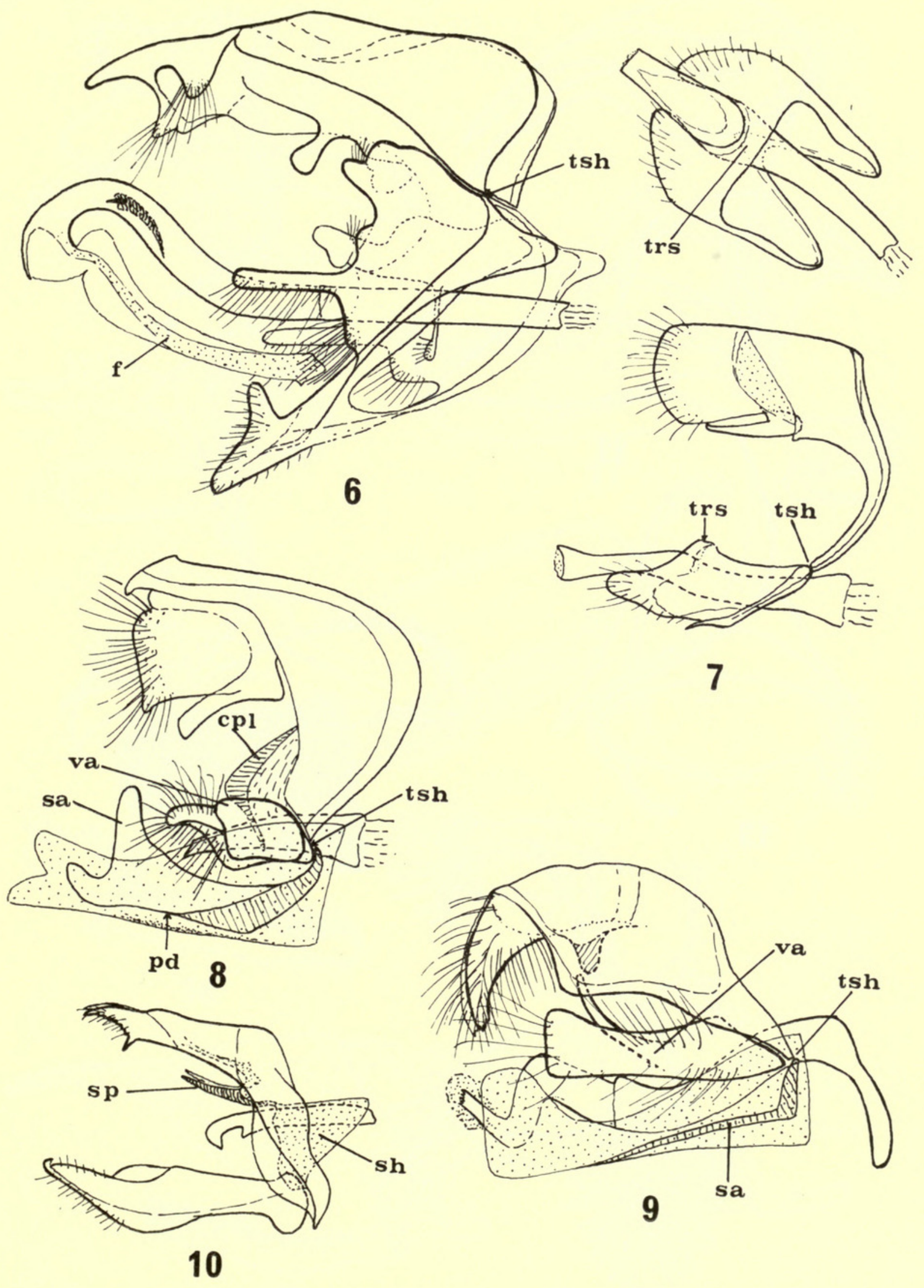

Figs 6-Io. Male genitalia. 6. Pentila tropicalis (Boisduval), complete armature. 7. Alaena amazoula Boisduval. 8. Telipna acraea (Westwood), 8th sternite dotted. 9. Ornipholidotos peucetia (Hewitson), 8th sternite dotted. Io. Baliochila aslauga (Trimen). 


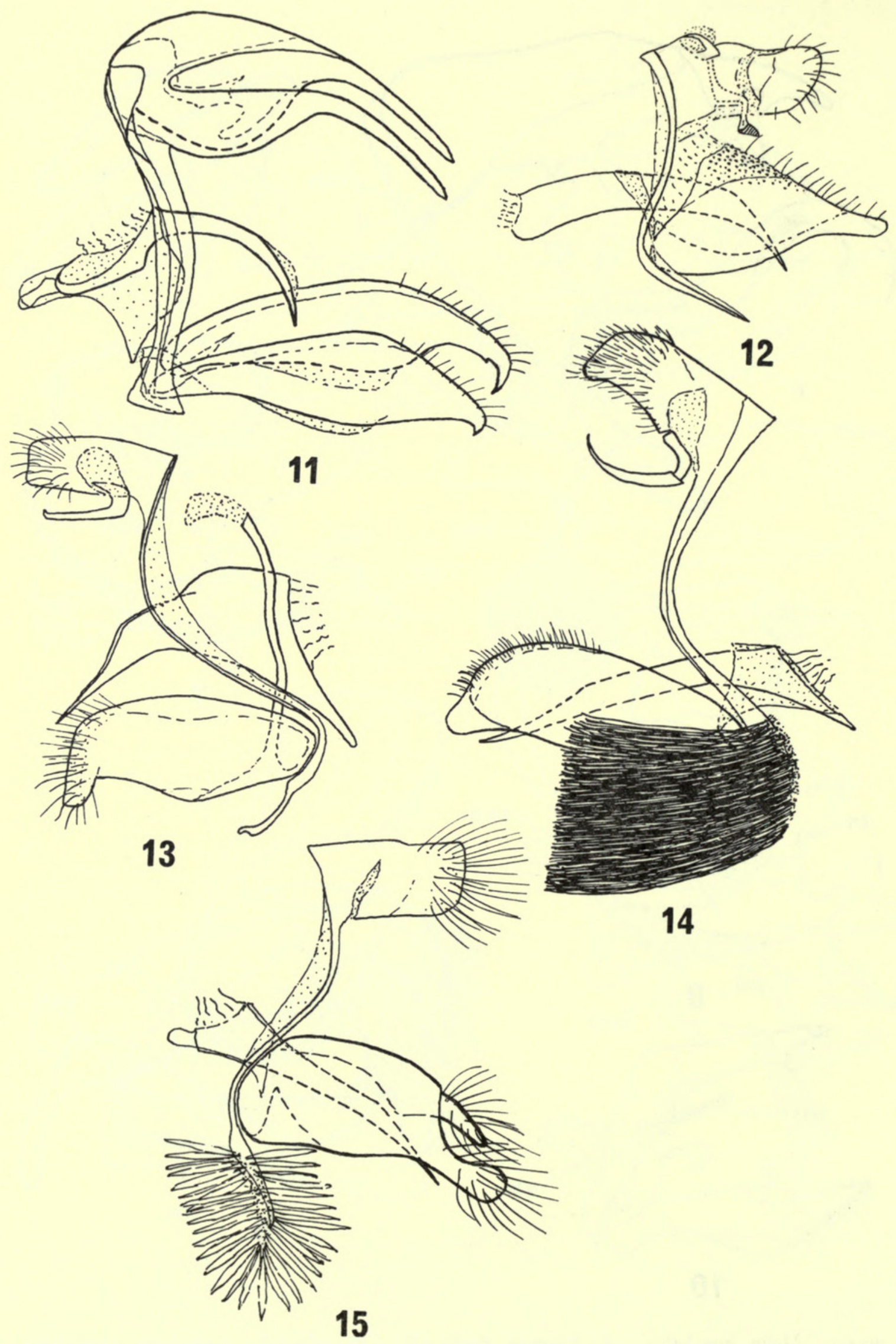

FIgS II-I5 Male genitalia. II. Mimeresia libentina (Hewitson), complete armature. 12. Durbania amakosa Trimen. 13. Tetrarhanis ilma (Hewitson). 14. Aethiopana honorius (Fabricius). I5. Teratoneura isabellae Dudgeon. 

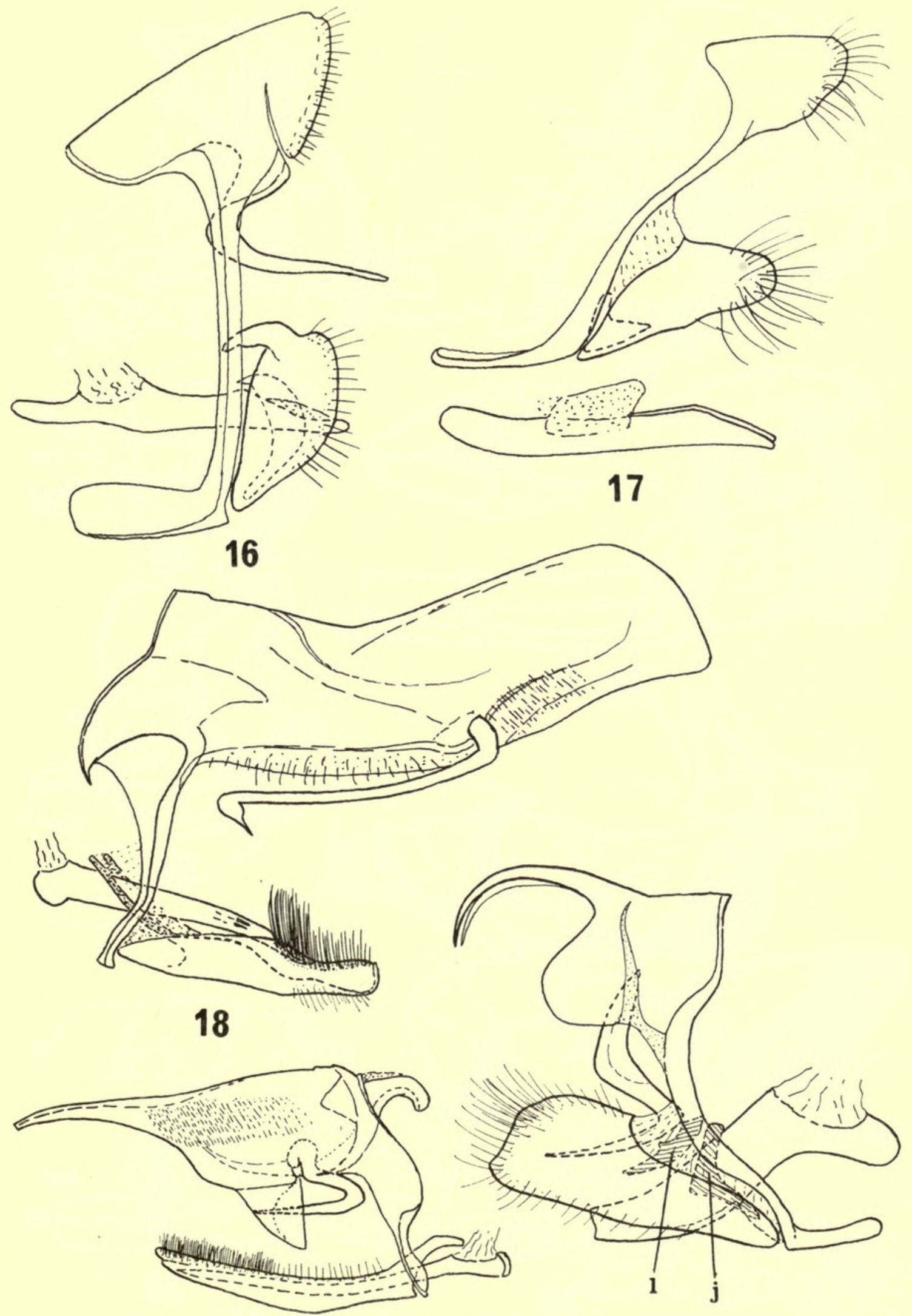

19

20

FIgS I6-20 Male genitalia. 16. Euliphyra mirifica Holland. I7. Egumbia ernesti (Karsch). I8. Miletus gaesa (de Nicéville). r9. Megalopalpus zymna (Westwood). 20. Thestor protumnus (L). 

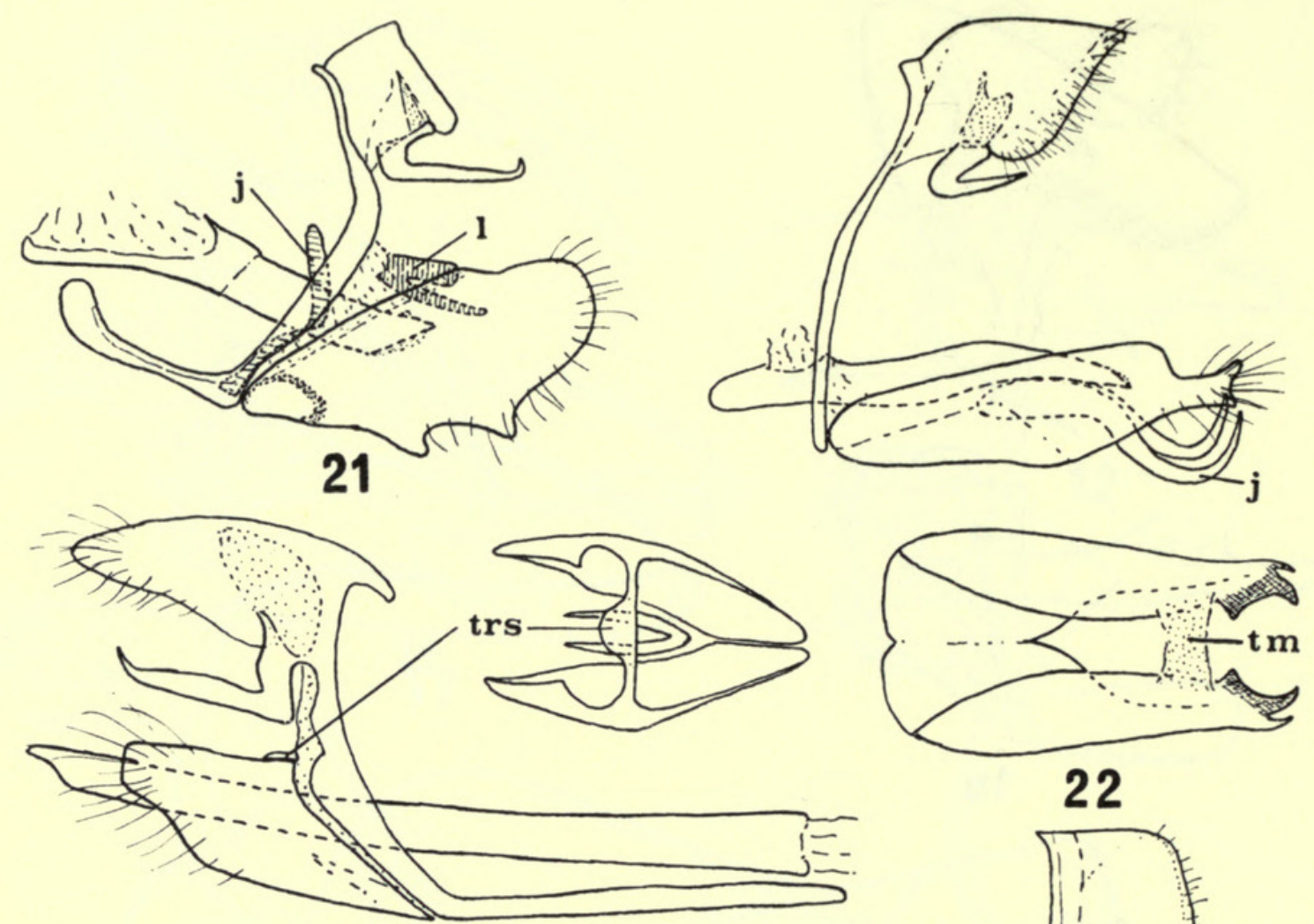

22
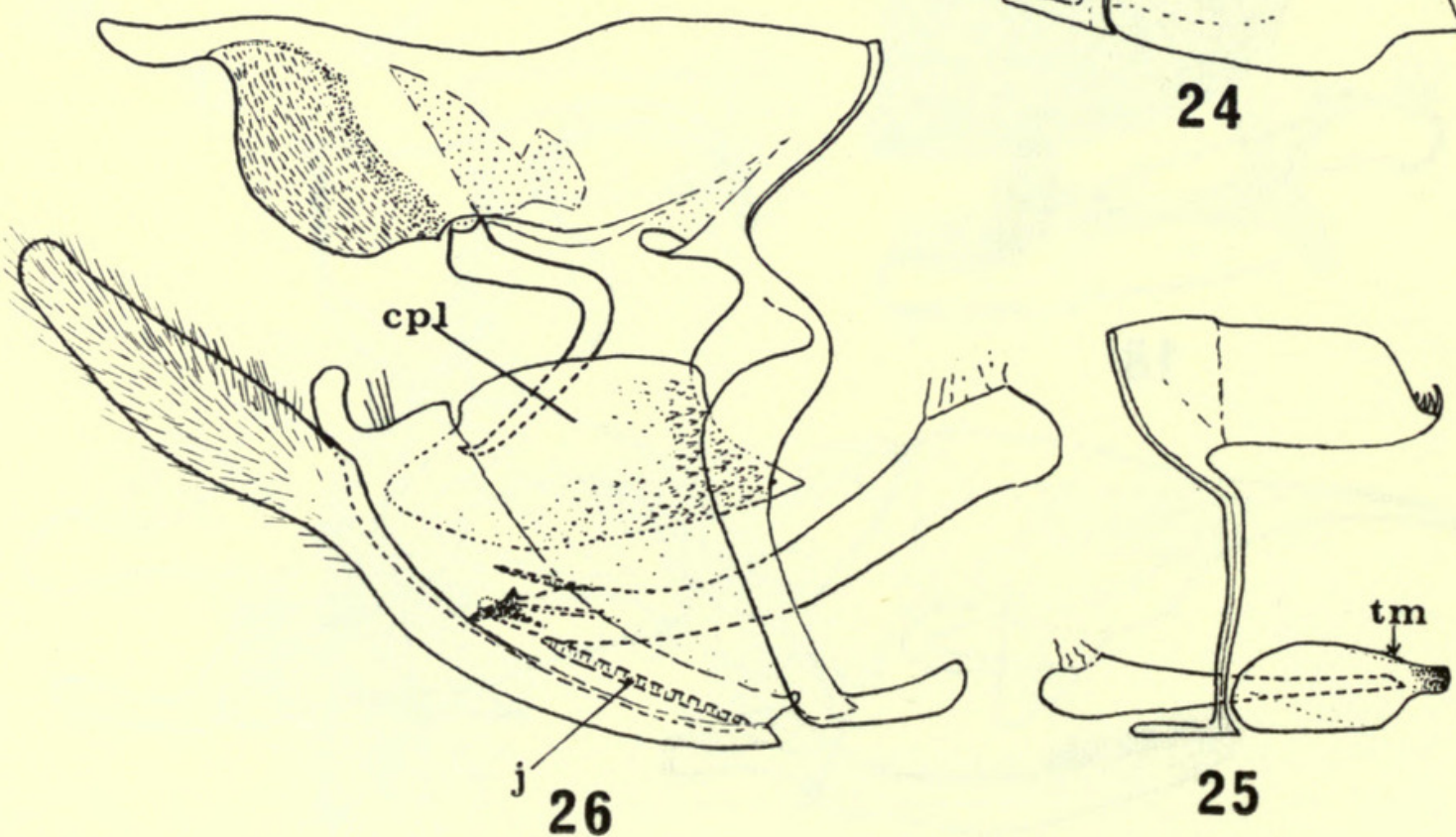

FIgS 21-26. Male genitalia. 2I. Lachnocnema bibulus (Fabricius). 22. Spalgis epius (Westwood). 23. Feniseca tarquinius (Fabricius). 24. Taraka mahanetra Doherty. 25. Taraka hamada (H. Druce). 26. Curetis regula Evans. 

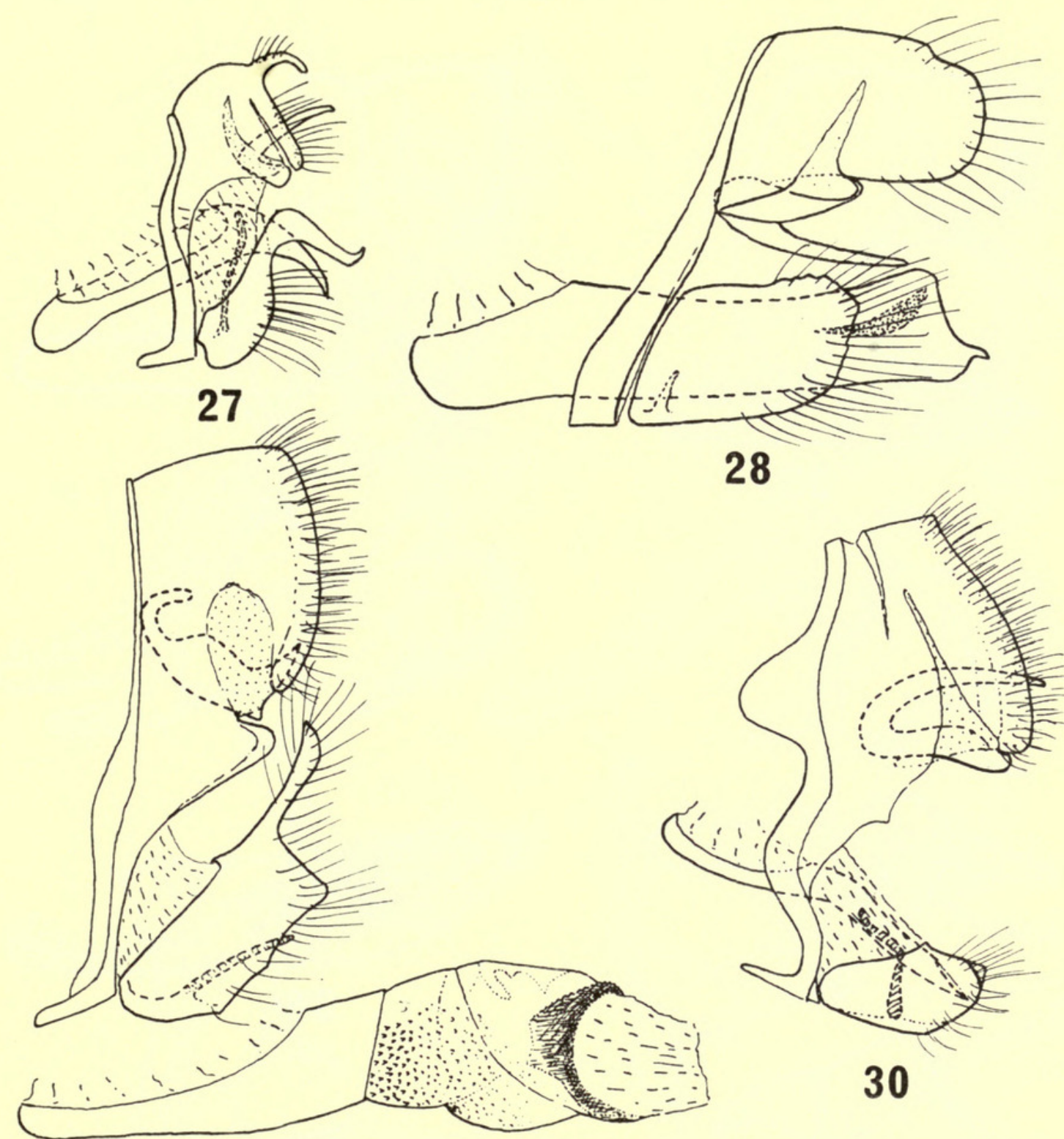

\section{9}
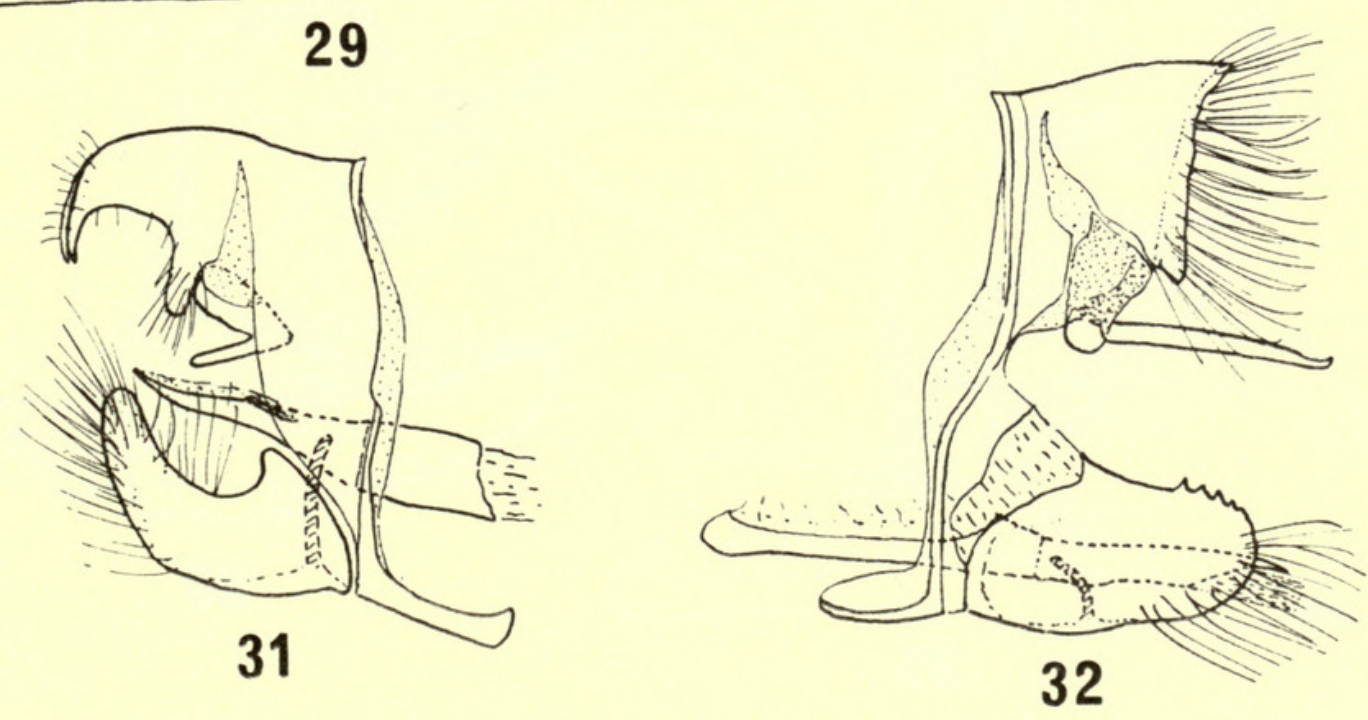

FIgS 27-32. Male genitalia. 27. Paralucia aenea (Miskin). 28. Waigeum ribbei Röber. 29. Quercusia quercus (L.). 30. Thecla betulae (L.). 31. Chaetoprocta odata (Hewitson). 32. Amblopala avidiena (Hewitson). 

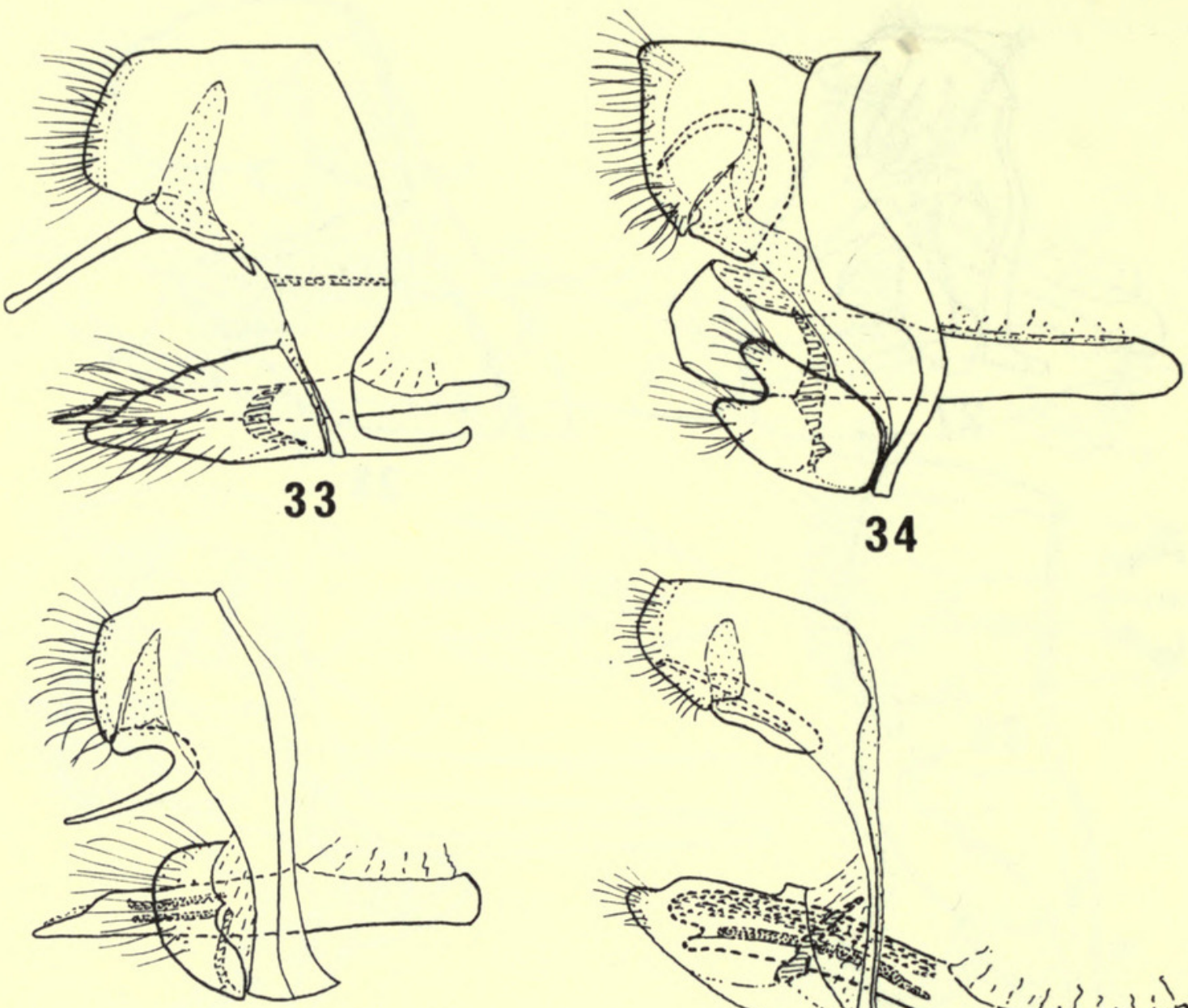

35
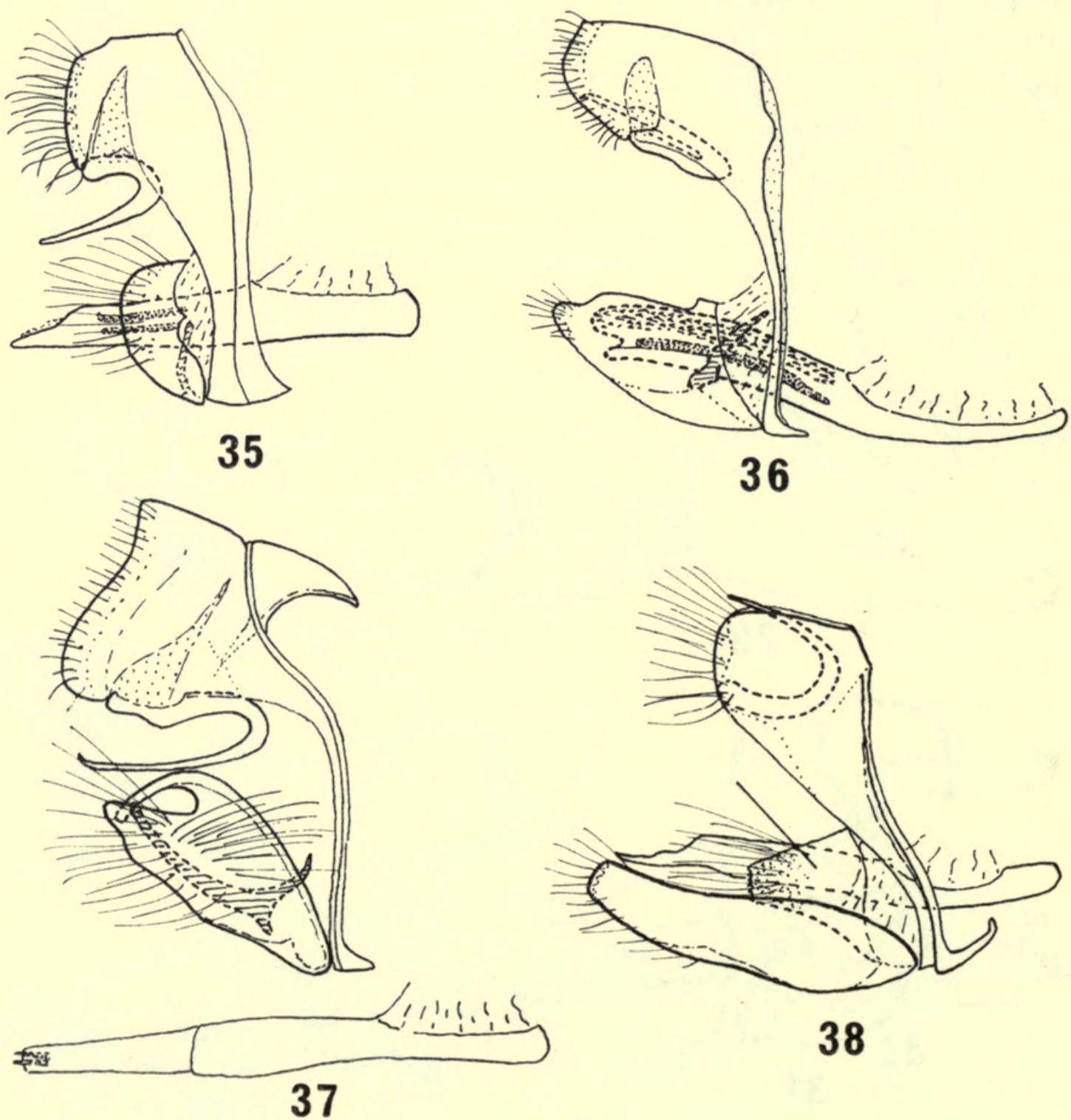

36

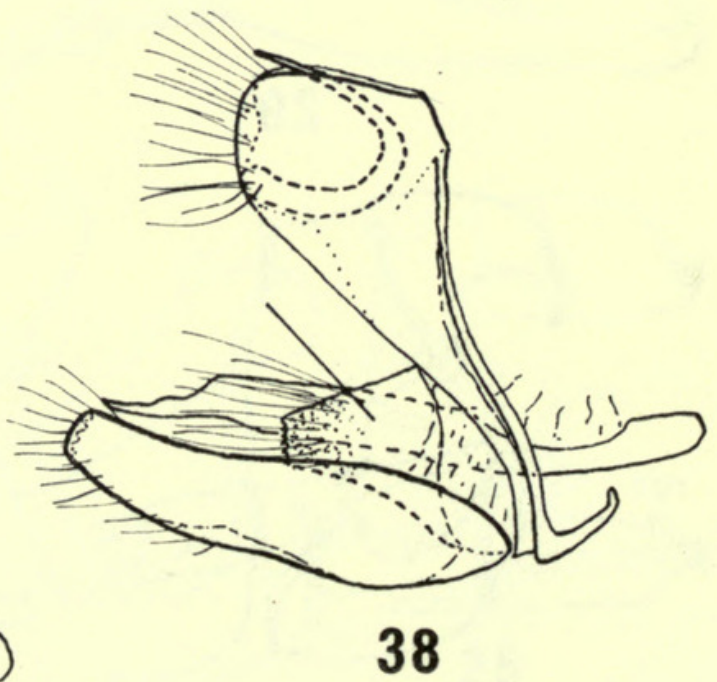

Figs 33-38. Male genitalia. 33. Arhopala critala (Felder). 34. Ogyris genoveva Hewitson. 35. Hypothecla astyla (Felder). 36. Jalmenus evagoras (Donovan). 37. Pseudalmenus chlorinda (Blanchard). 38. Zesius chrysomallus Hübner. 

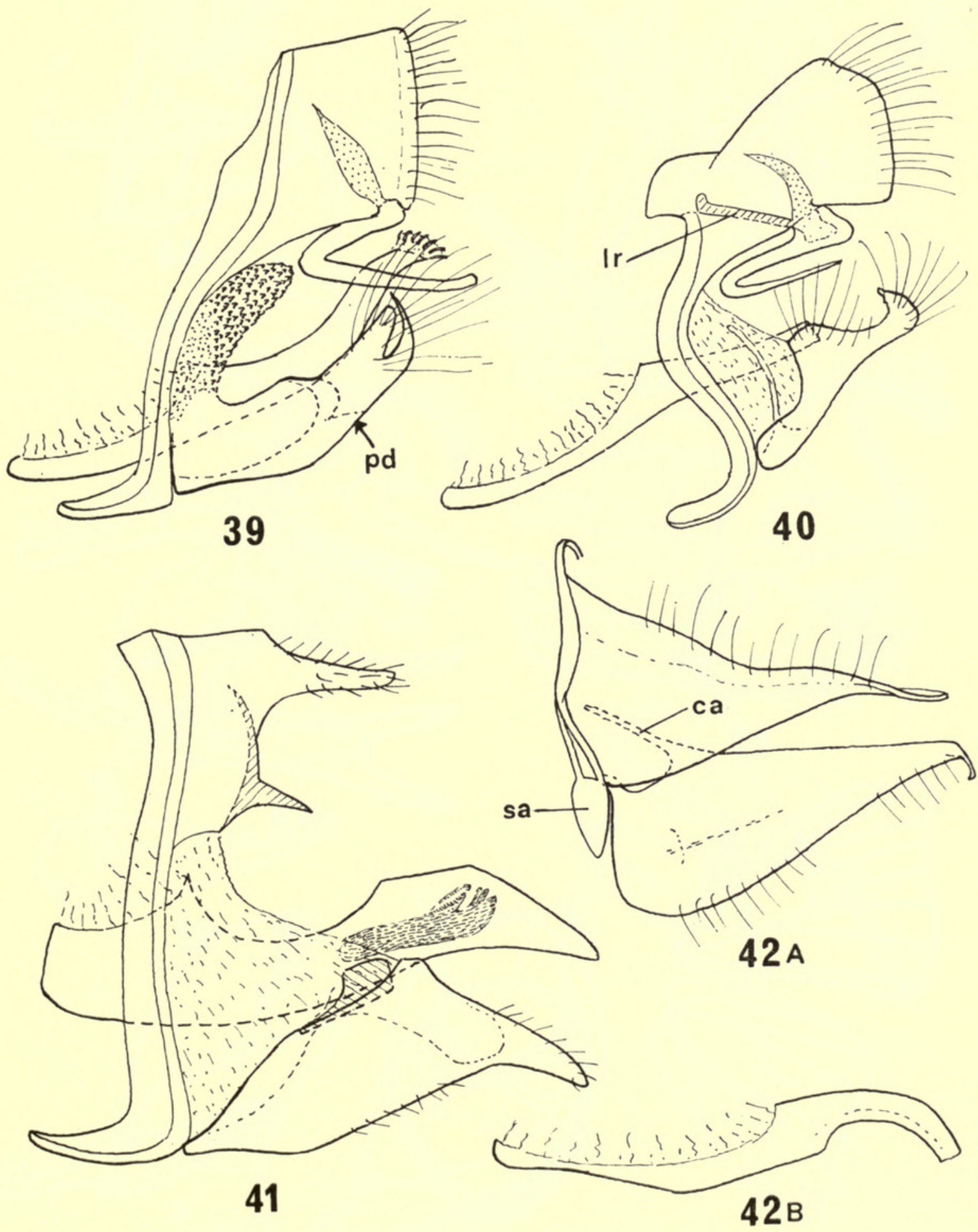

Figs 39-42. Male genitalia. 39. Zinaspa todara (Moore). 40. Mota massyla (Hewitson). 4I. Pseudaletis clymenus (H. H. Druce). 42. Cowania achaja (Fruhstorfer), A, lateral view without penis; $\mathrm{B}$, penis. 


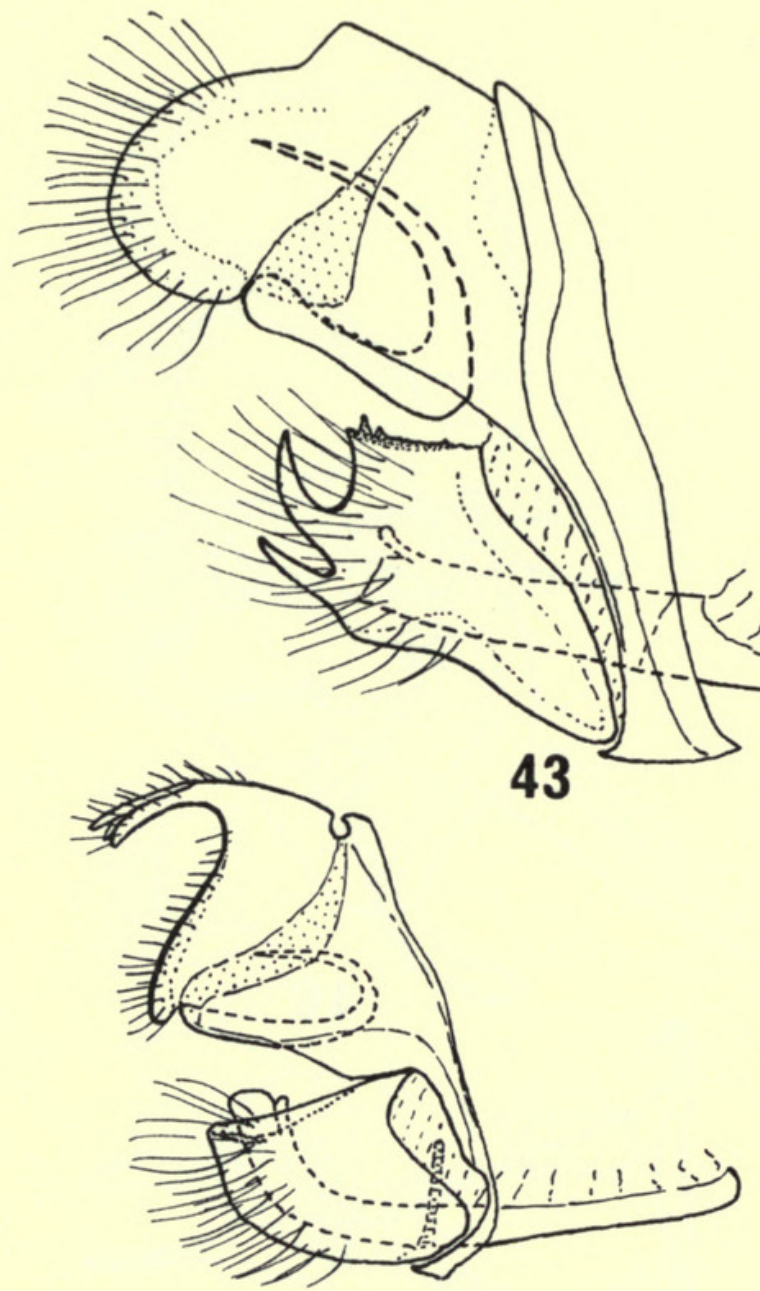

45

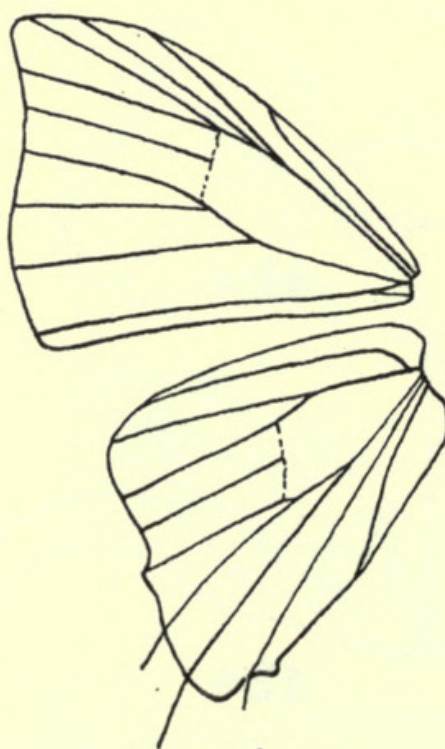

A

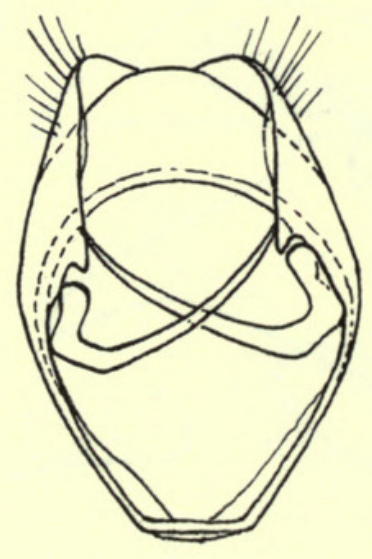

B

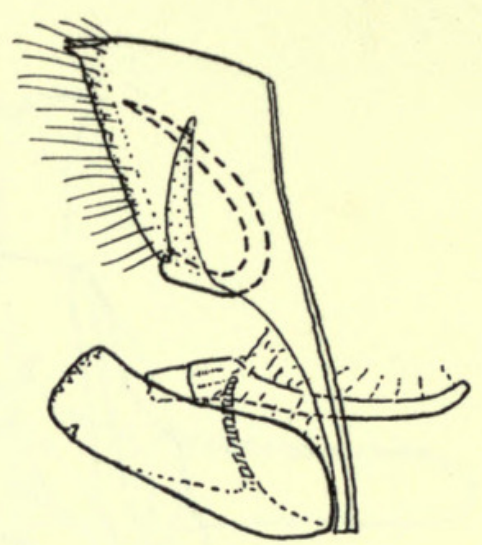

44

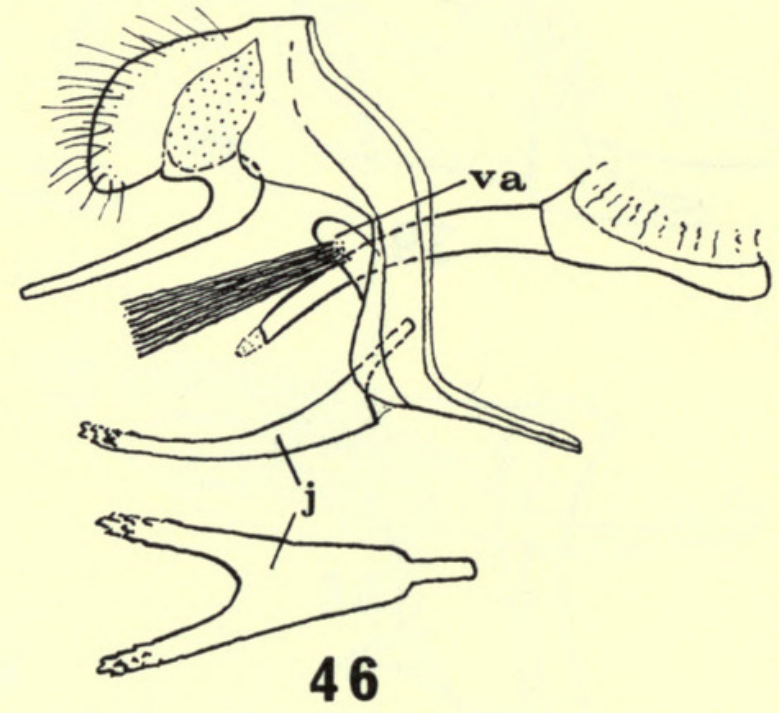

47

Figs 43-47. Male genitalia and wing-venation. 43. Amblypodia narada Horsfield. 44. Catapaecilma major Fruhstorfer. 45. Myrina silenus (Fabricius). 46. Syrmoptera amasa (Hewitson). 47. Acupicta delicatum (de Nicéville), A, venation; B, ring viewed distally; $\mathrm{C}$, lateral view of armature. 


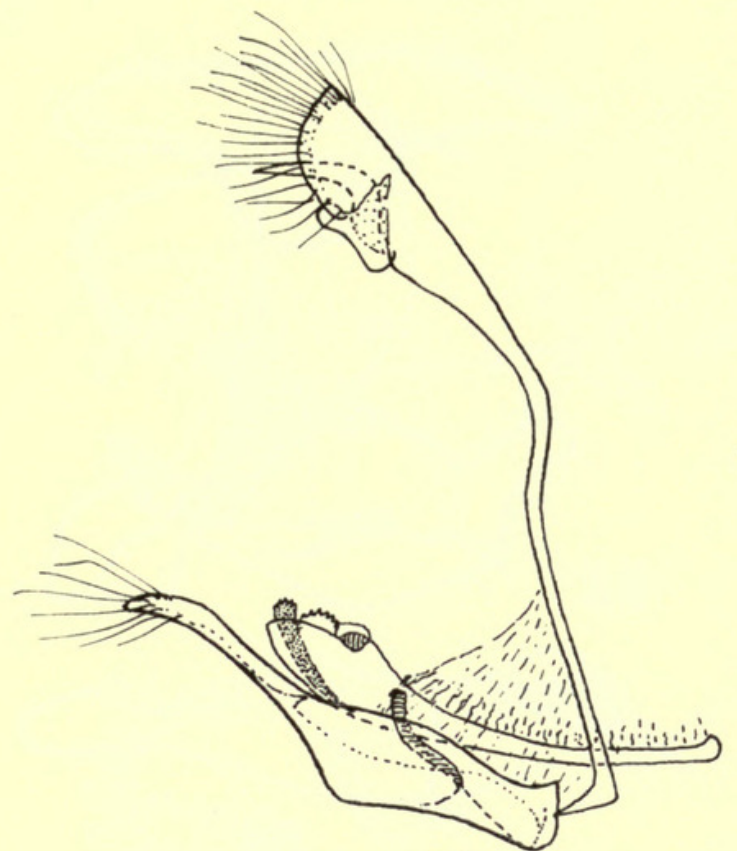

48
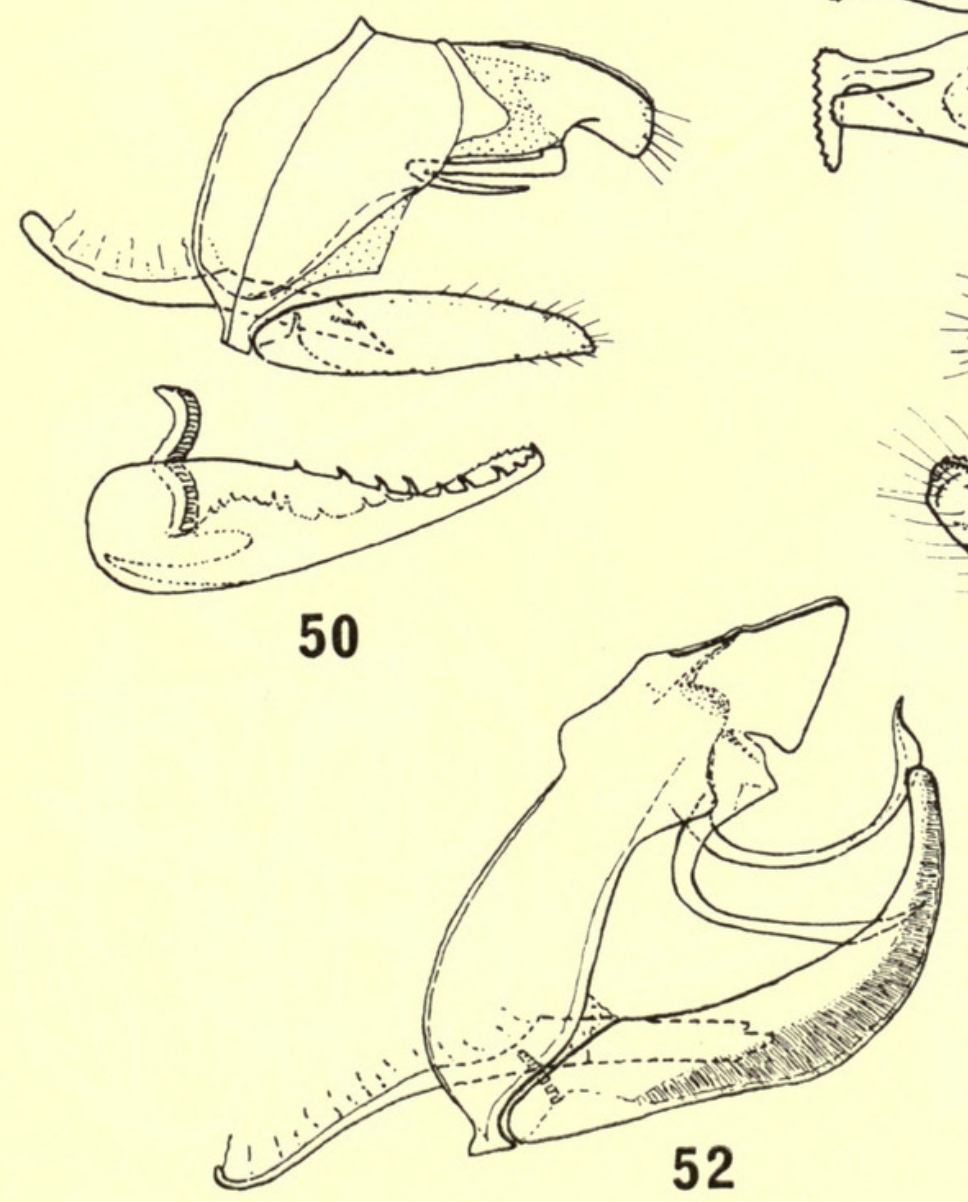
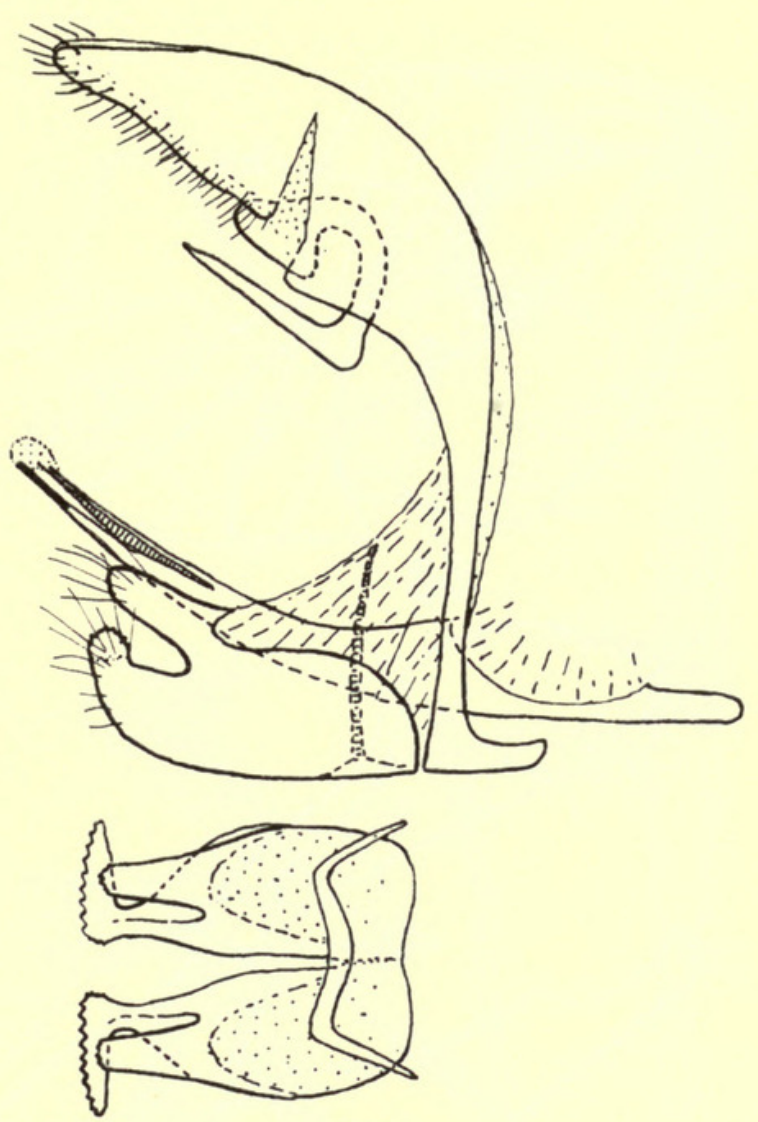

49

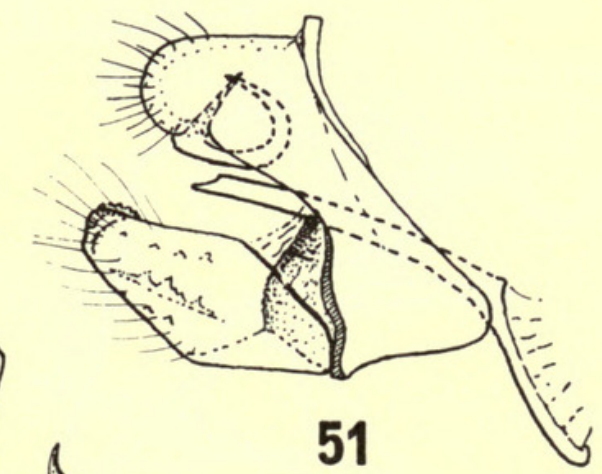

Figs 48-52. Male genitalia. 48. Drina cowani Corbet. 49. Neomyrina nivea (Godman \& Salvin), above, complete armature; below, dorsal view of valvae + juxta. 50. Loxura cassiopeia Distant. 5I. Thamala marciana (Hewitson). 52. Horaga maenala (Hewitson), complete armature less right valva. 


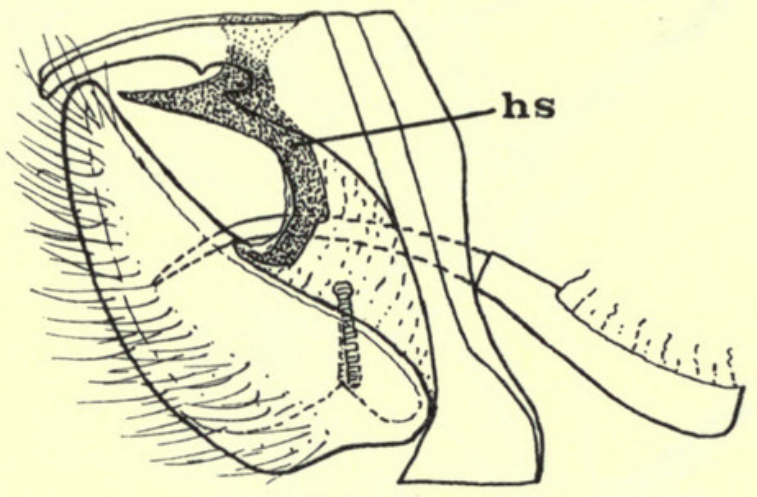

53

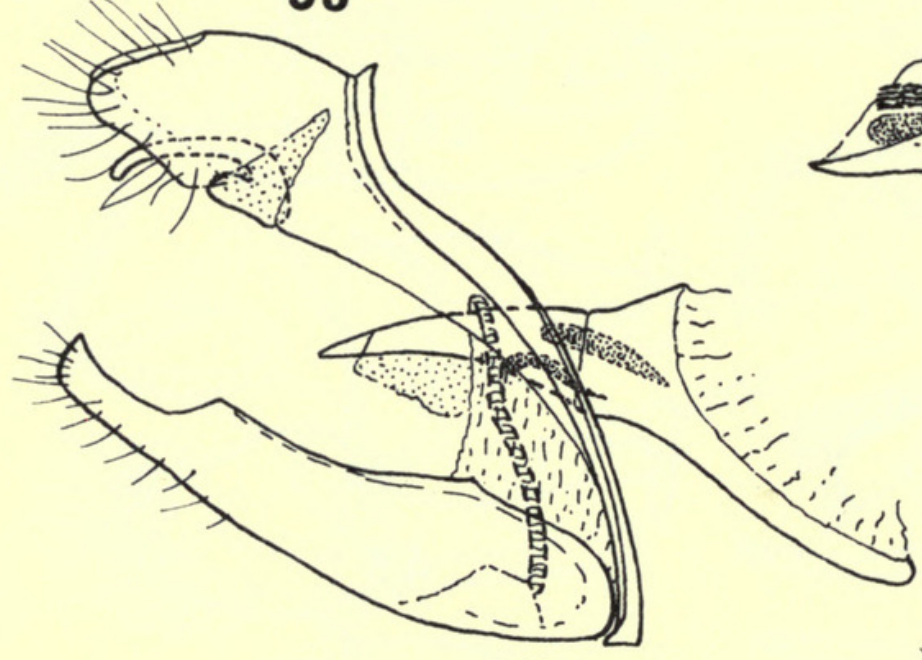

55

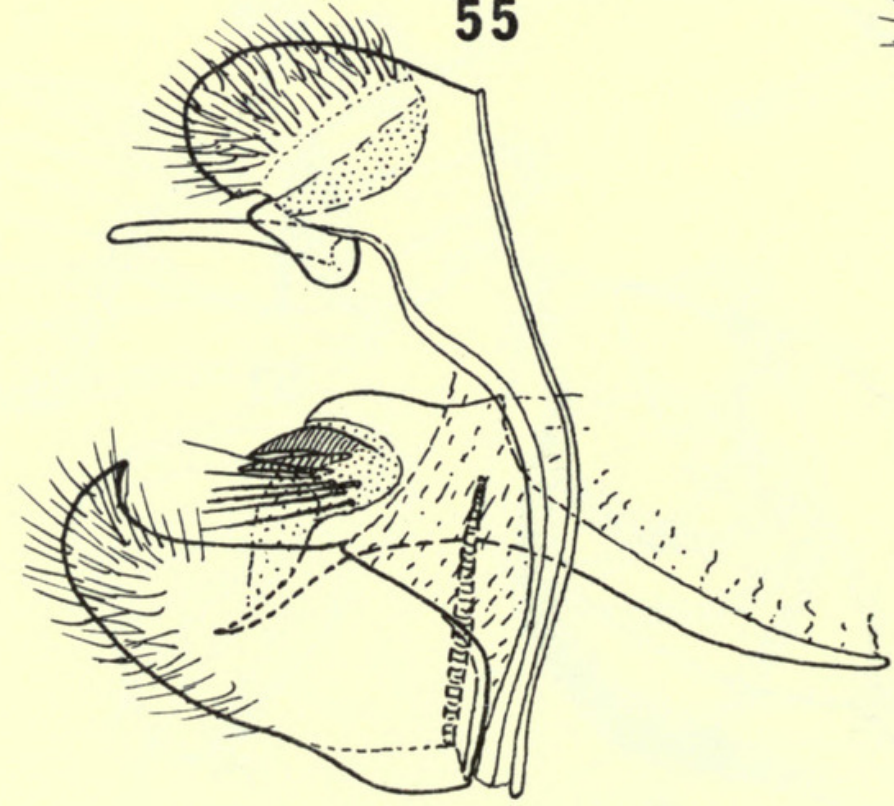

57

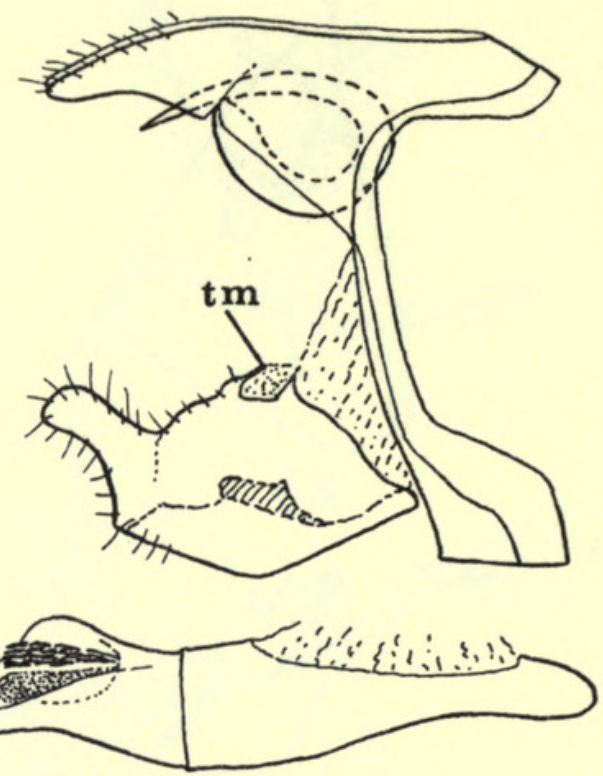

54

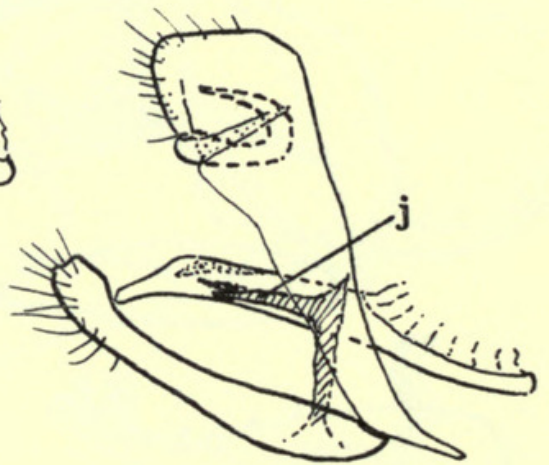

56

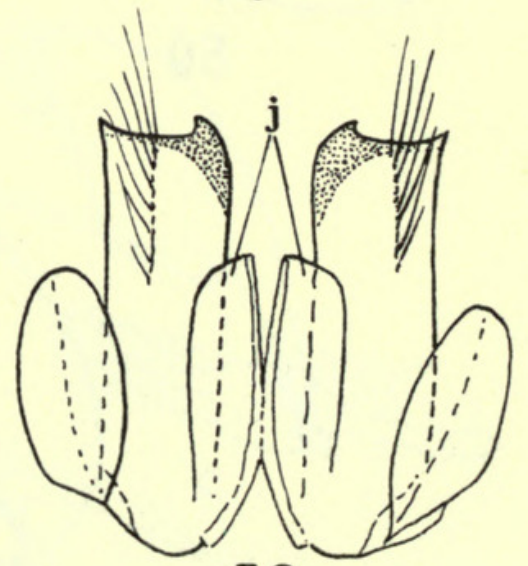

58

FIgS 53-58. Male genitalia. 53. Dapidodigma hymen (Fabricius). 54. Spindasis syama (Horsfield). 55. Iolaus eurisus (Cramer). 56. Pratapa deva (Moore). 57. Jacoona anasuja (Felder). 58. Hemiolaus coeculus (Mabille), dorsal view of valvae + juxta. 


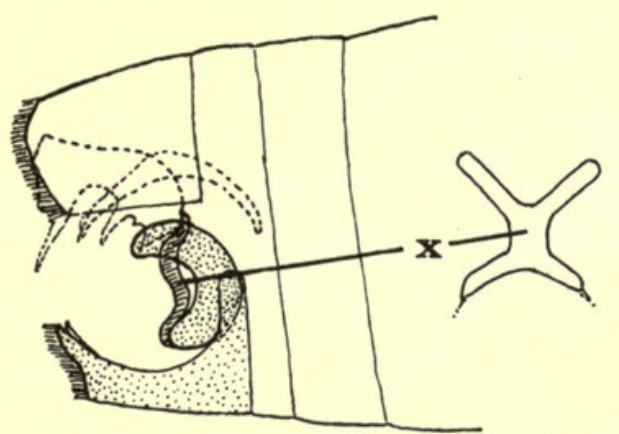

59
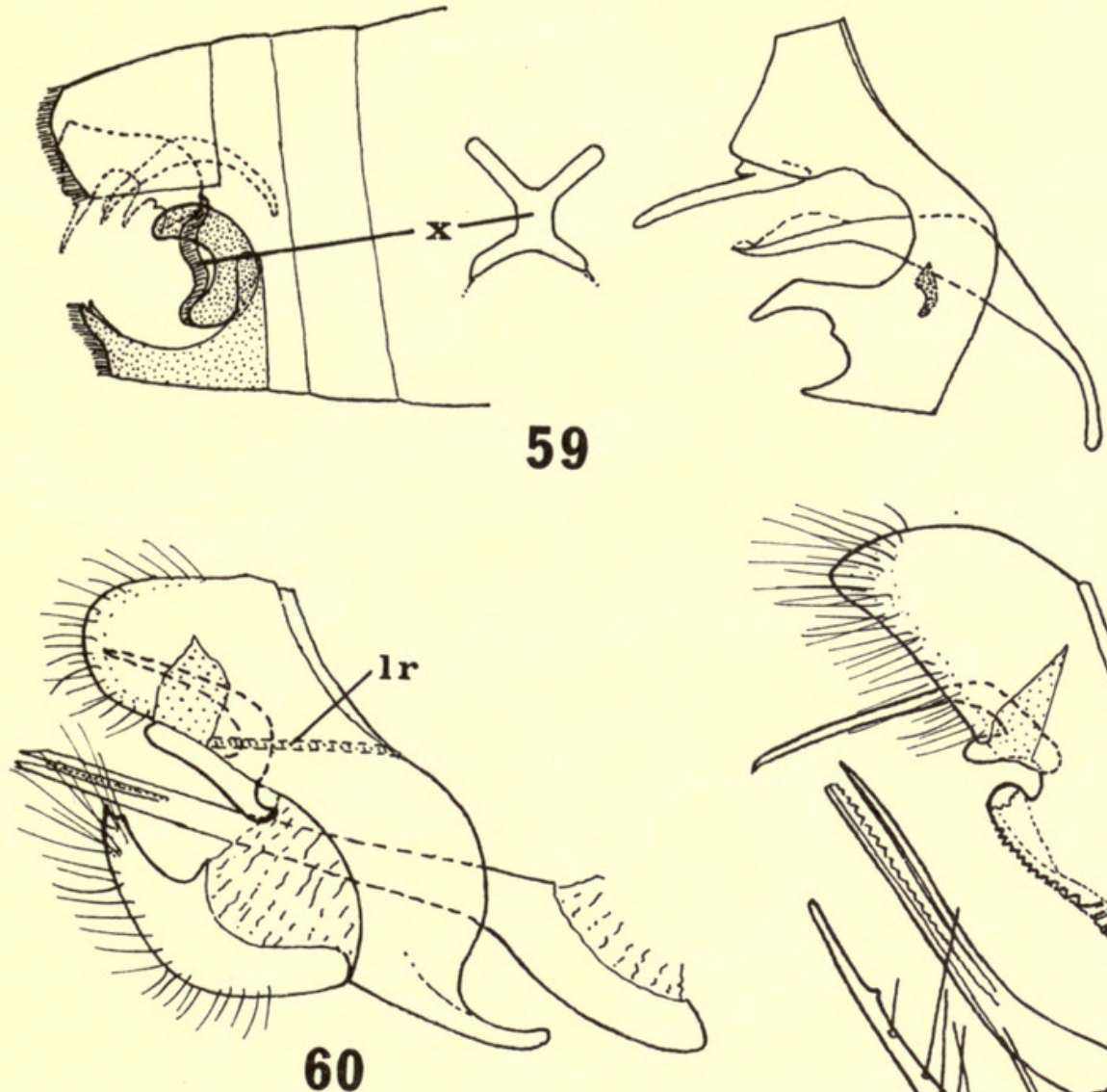

60

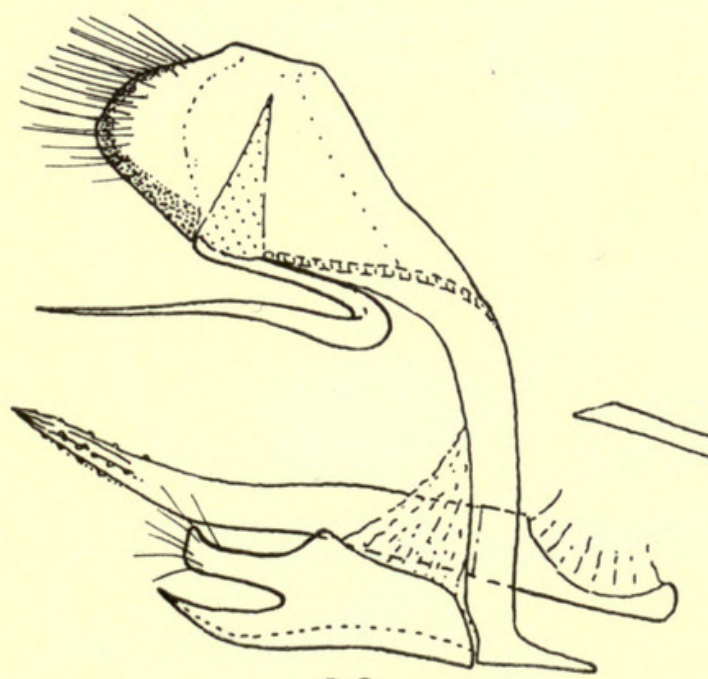

62
61
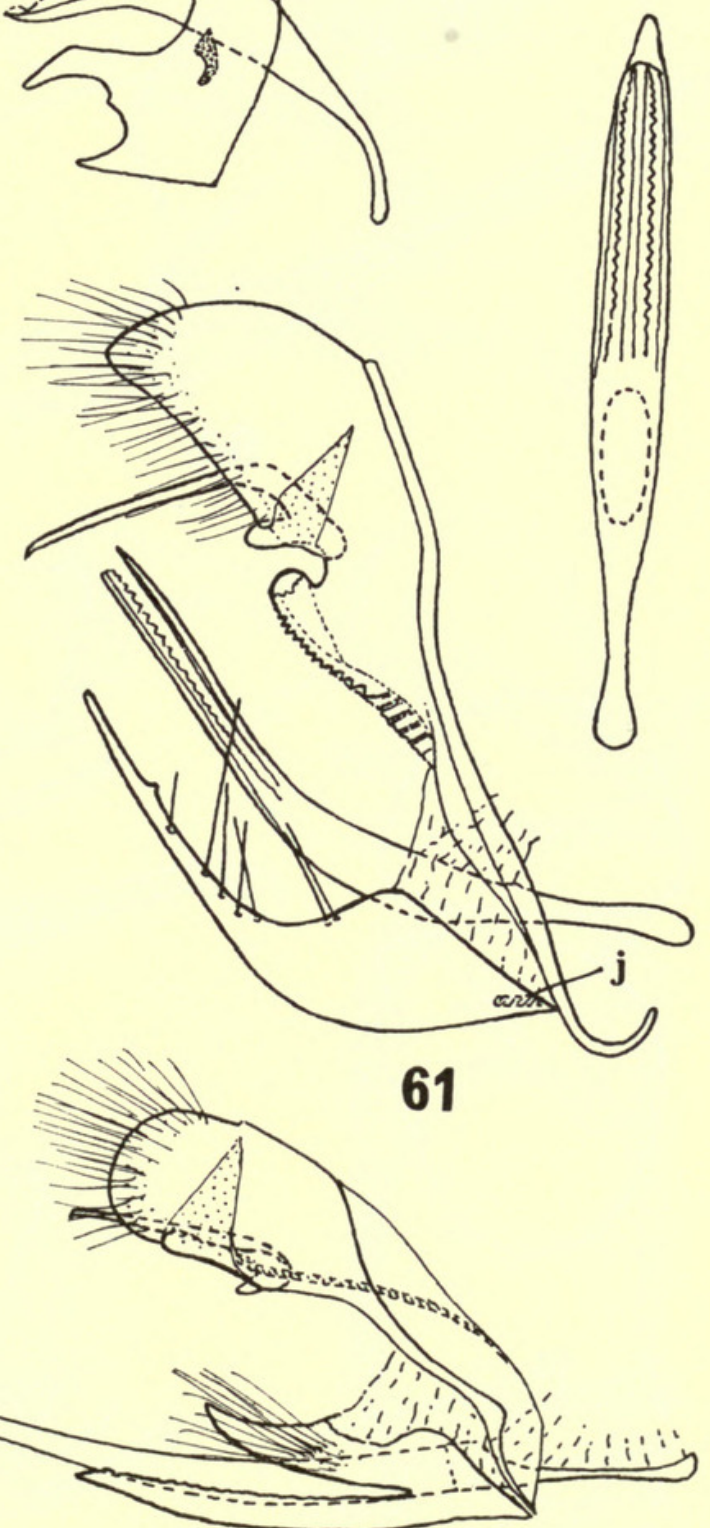

63

FIGS 59-63. Male genitalia. 59. Britomartis cleoboides (Elwes), left, terminal portion of abdomen to show armature in situ and abdominal chitinous structures; centre, X-piece; right, armature. 60. Gonatomyrina lava (L.). 61. Remelana jangala (Horsfield) armature and, above right, dorsal view of penis. 62. Pseudotajuria donatana (de Nicéville). 63. Ancema blanka (de Nicéville). 

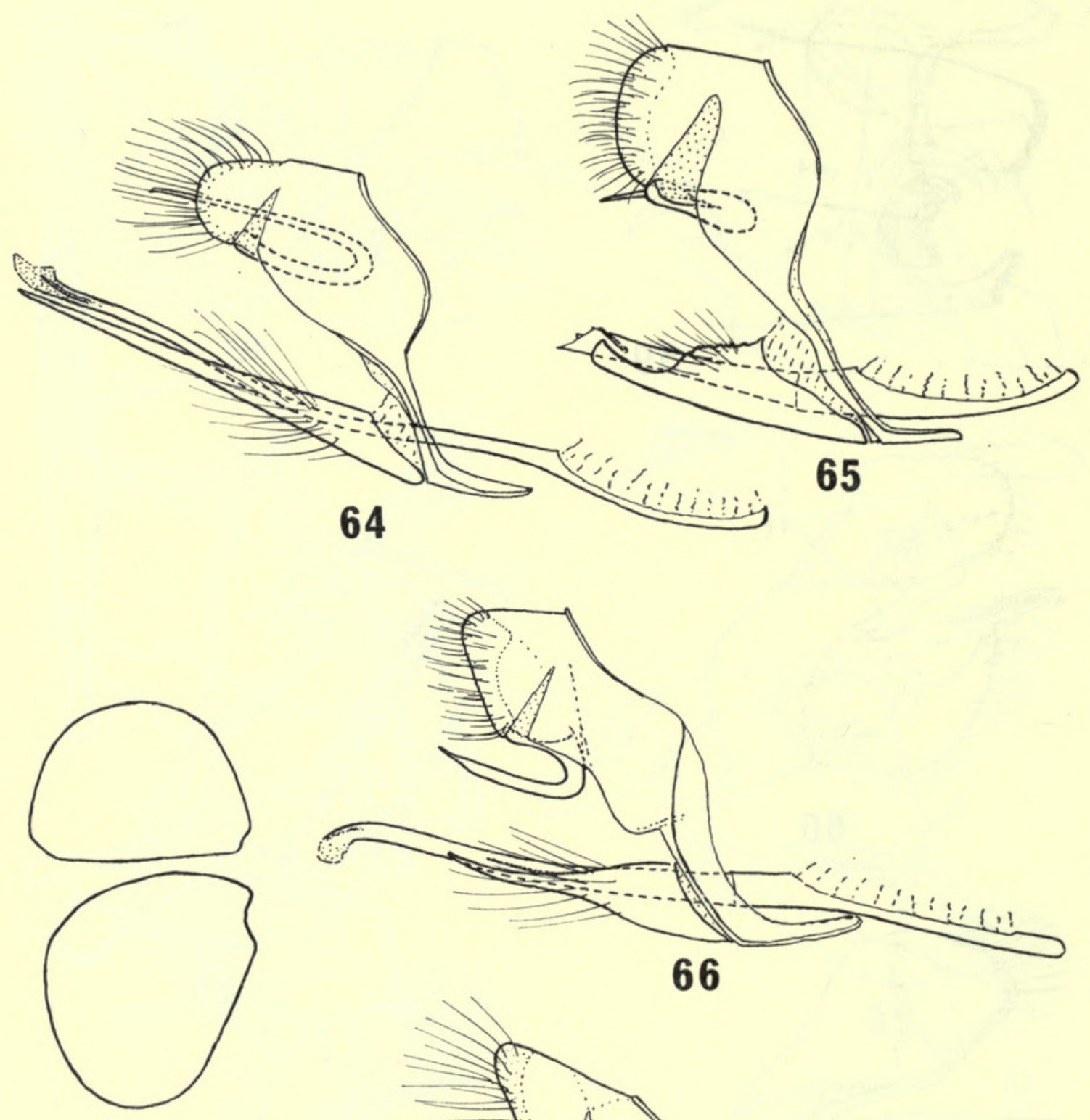

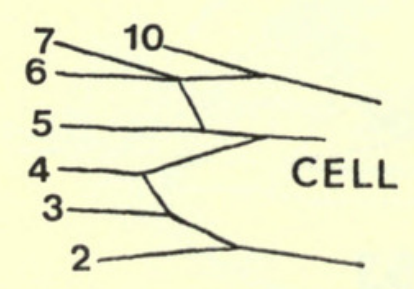

67

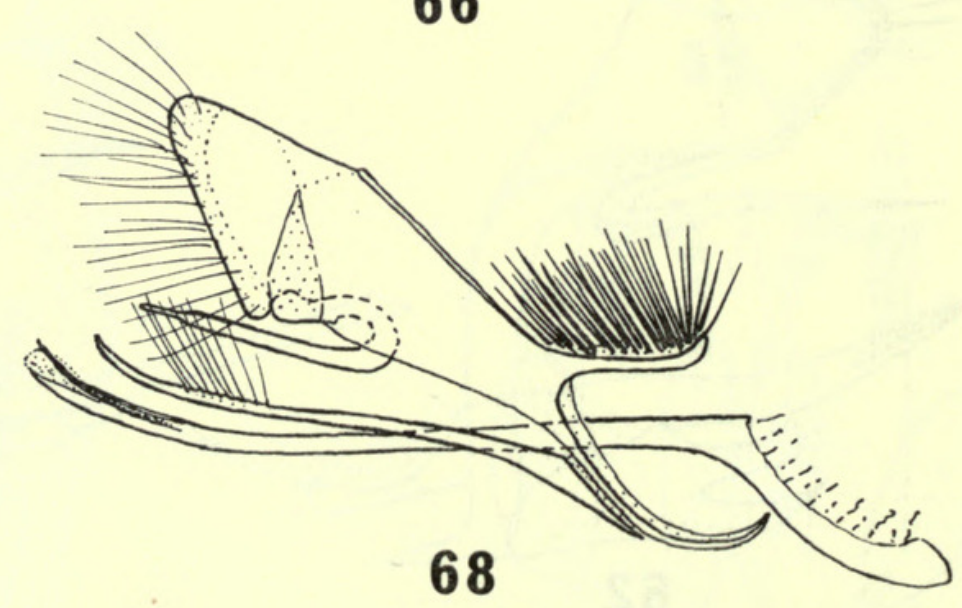

FIgs 64-68. Male genitalia and wing venation. 64. Tomares ballus (Fabricius). 65. Deudorix epijarbas (Moore). 66. Strymon melinus Hübner. 67. Micandra platyptera (Felder), above, outline of wings; below, venation of part of fore wing. 68. Thereus lausus (Cramer). 

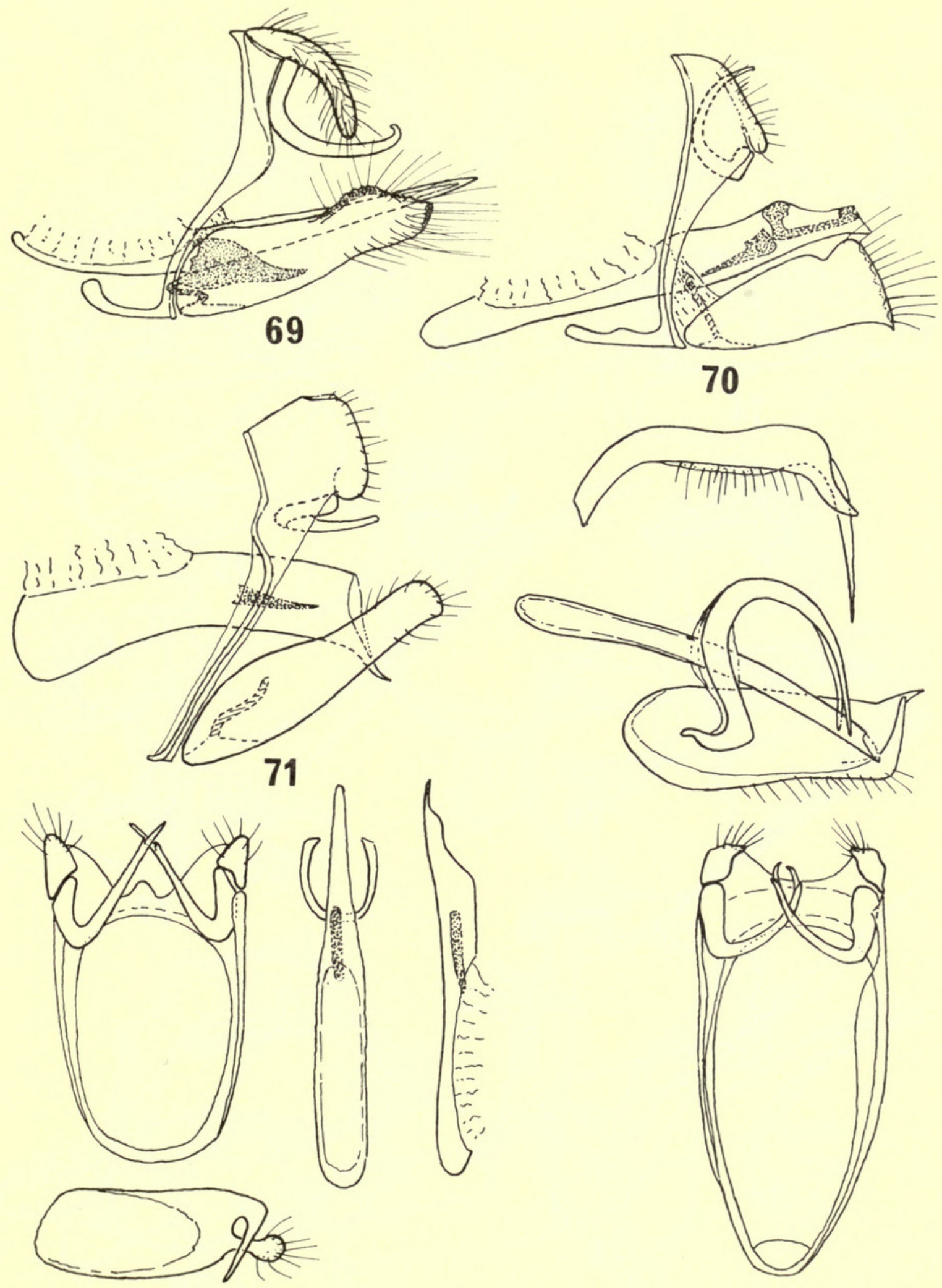

72

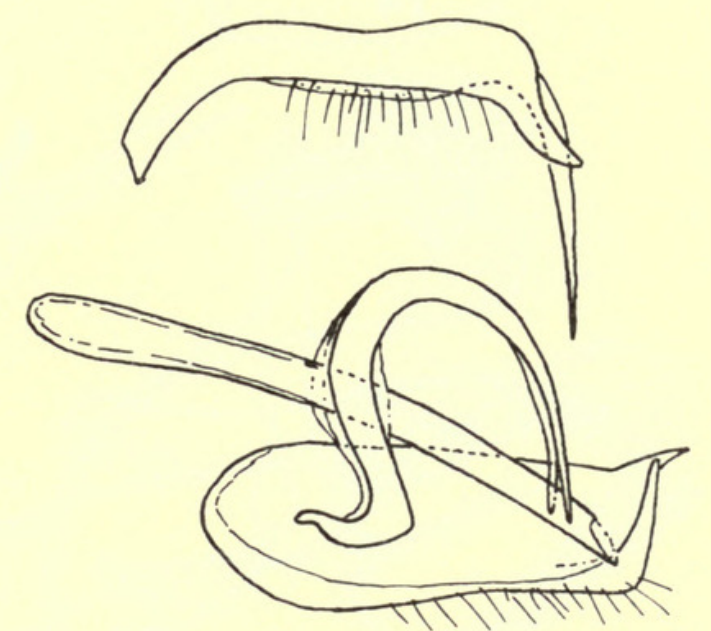

70

Figs 69-73. Male genitalia. 69. Lycaena salustius (Fabricius). 70. Lycaenesthes lycaenoides (Felder). 71. Niphanda tessellata Moore. 72. Zetona delospila (Waterhouse), ring viewed distally, dorsal view of penis + juxta, lateral view of penis and internal view of right valva. 73. Nesolycaena albosericea (Miskin), above, dorsal view of right valva; centre, internal view of right valva + juxta; below, distal view of ring. 


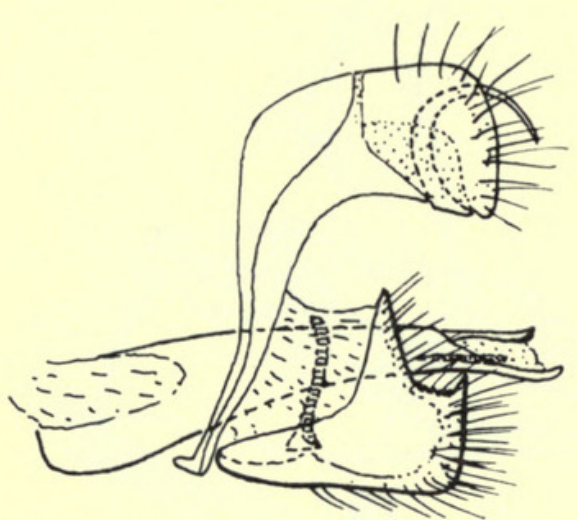

74

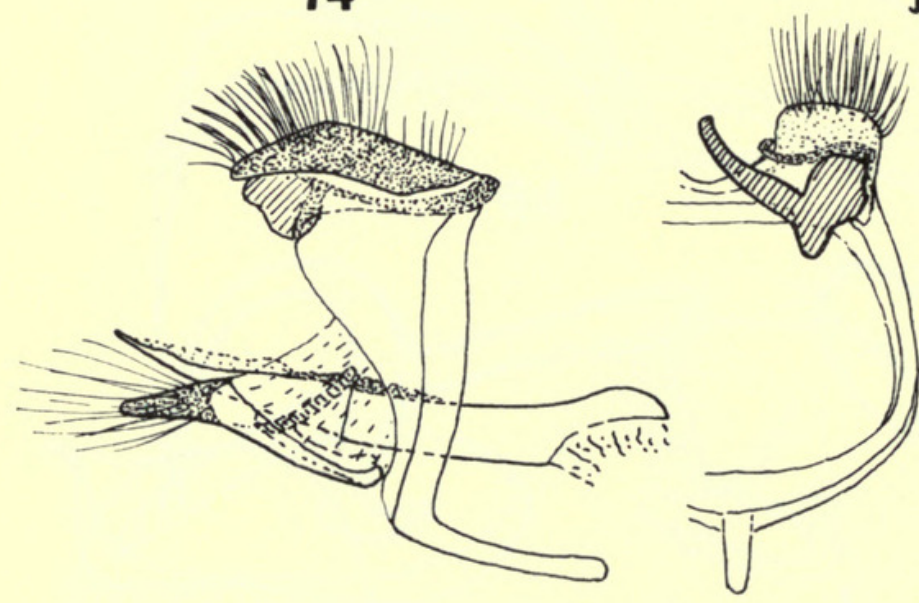

76

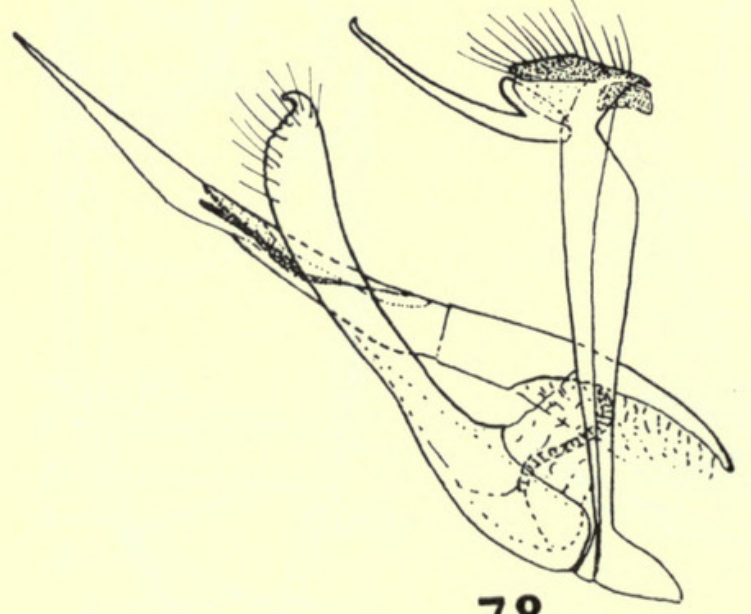

78

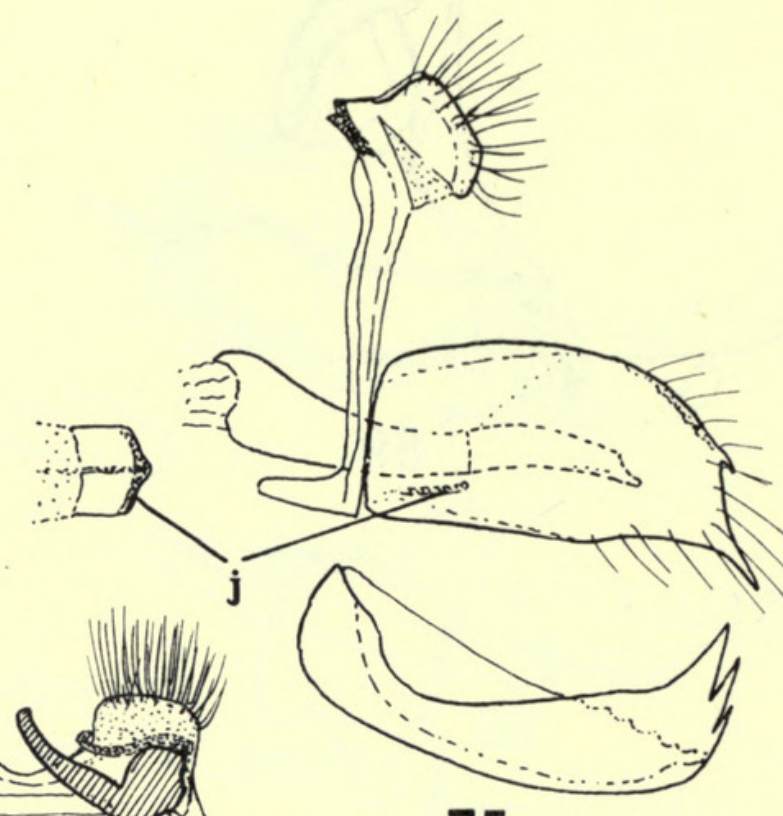

75

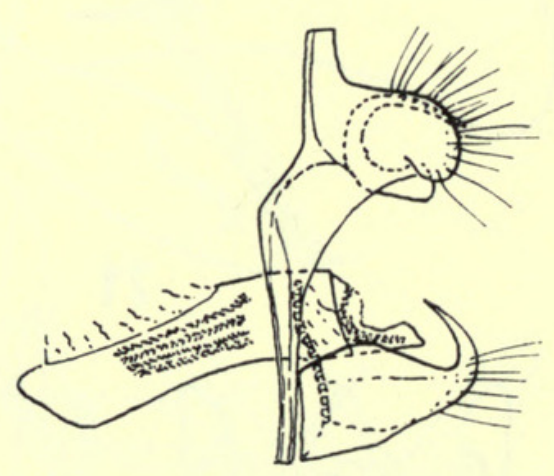

77

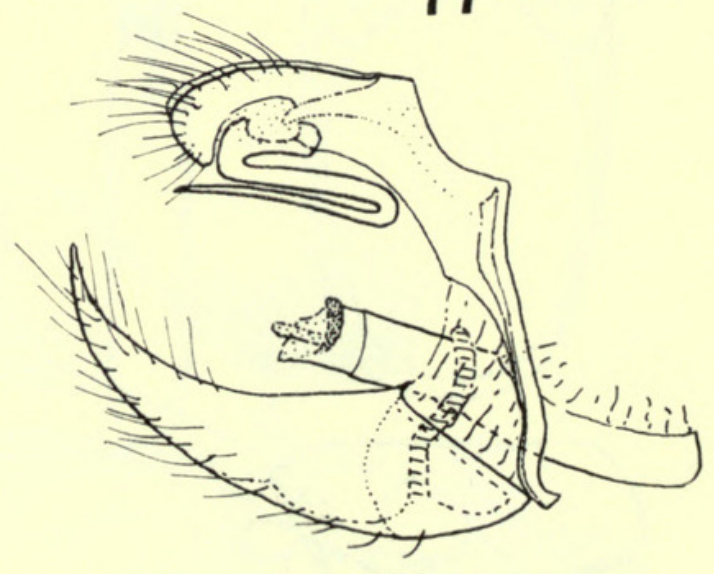

79

Figs 74-79. Male genitalia. 74. Cupidopsis cissus (Godart). 76. Una usta (Distant), armature and, below, ventral view of right valva. 76. Pseudonacaduba sichela (Wallengren), armature and, right, distal view of right half of ring. 77. Prosotas gracilis (Röber). 78. Petrelaea dana (de Nicéville). 79. Neolucia mathewi (Miskin). 

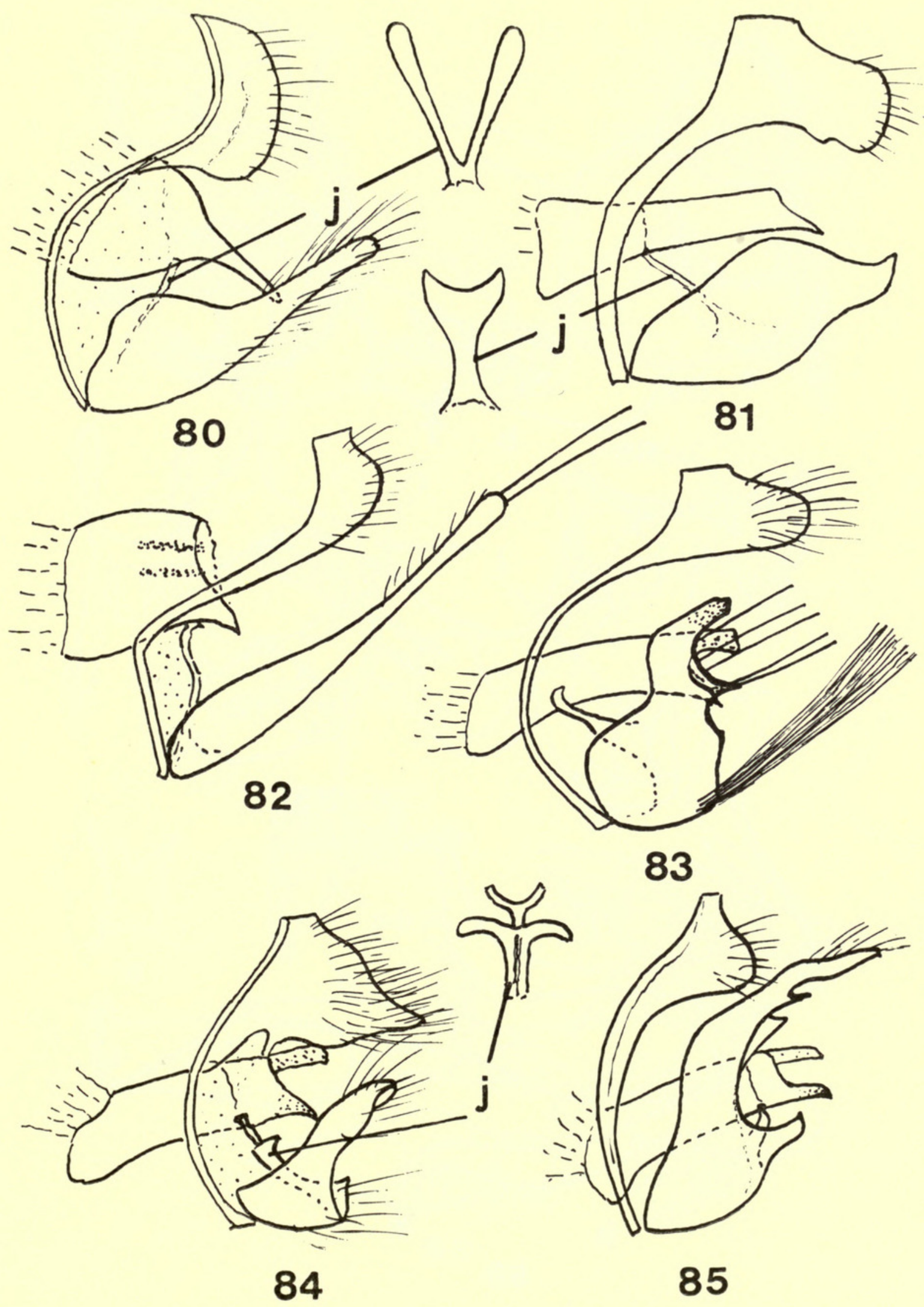

Figs 8o-85. Male genitalia. 8o. Discolampa illissus (Felder) comb.n. 81. Upolampes evena (Hewitson). 82. Discolampa ethion (Westwood). 83. Caleta decidia (Hewitson). 84. Caleta caleta (Hewitson). 85. Caleta mindarus (Felder). 


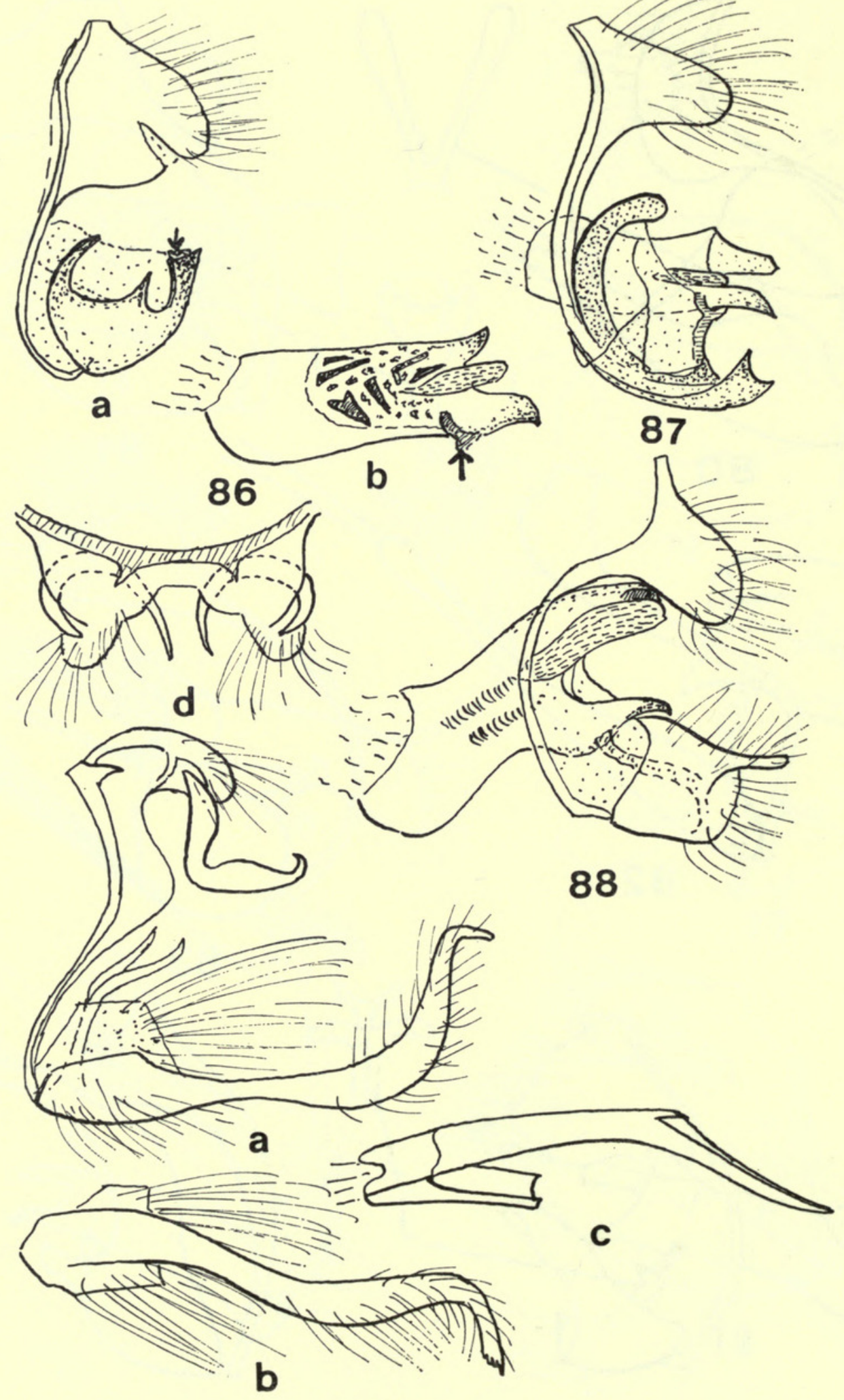

\section{9}

Figs 86-89. Male genitalia. 86. Pistoria nigropunctata (Bethune-Baker). 87. 'Caleta' (? gen. n.) elna (Hewitson). 88. Pycnothallium roxus (Godart). 89. Callictita arfakiana Wind \& Clench, a, lateral view of armature; b, ventral view of right valva, c; dorsolateral view of penis; d, dorsal view of dorsum. 


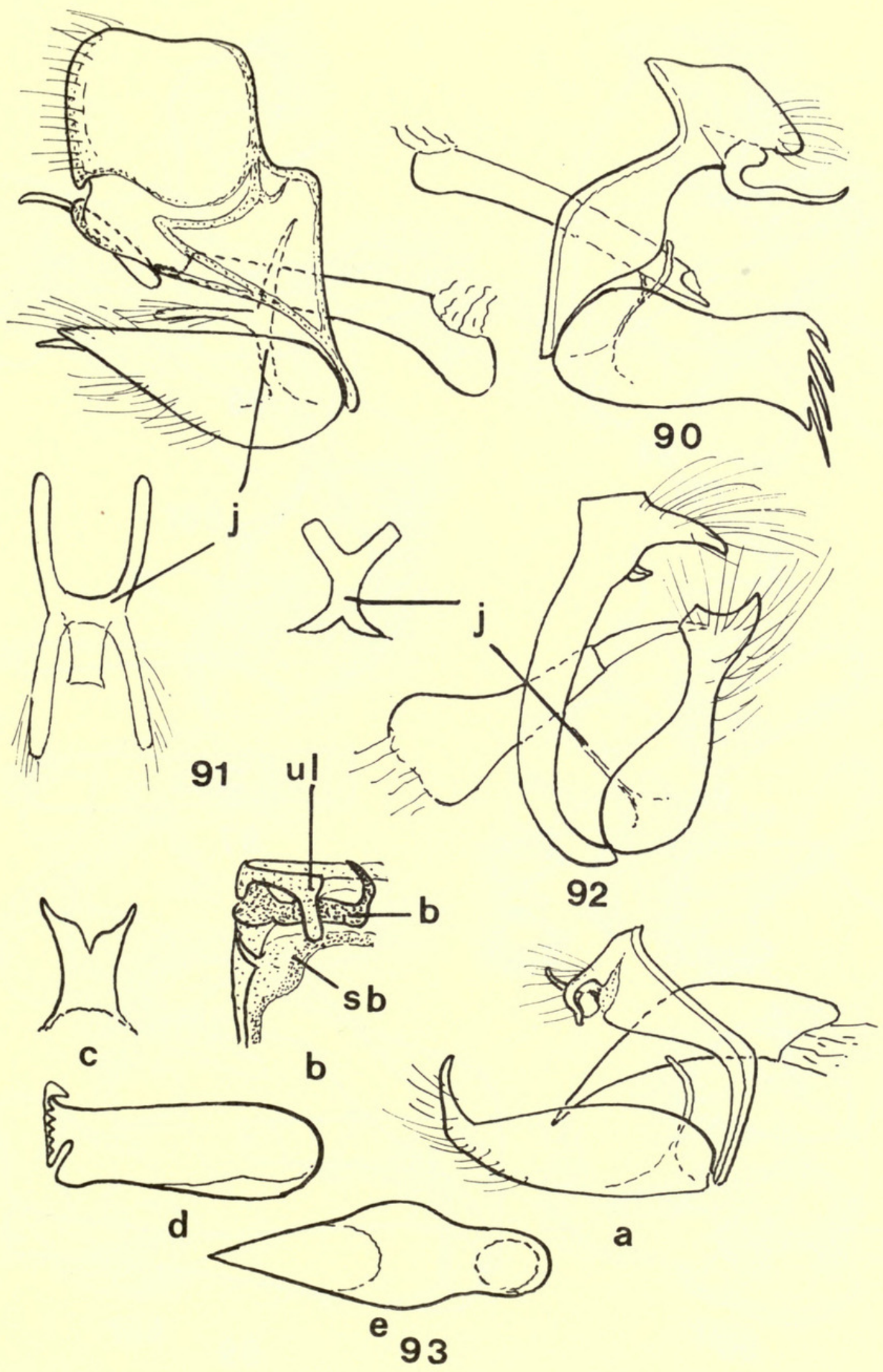

FIGS 90-93. Male genitalia. 90. 'Phlyaria' (Lycaena) heritsia (Hewitson). 91. Uranothauma nubifer (Trimen). 92. Thaumaina uranothauma Bethune-Baker. 93. Psychonotis purpurea (H. H. Druce) a, lateral view of armature; $b$, distal view of dorsal structures; c, juxta; d, internal view of left valva; e, dorsal view of penis. 

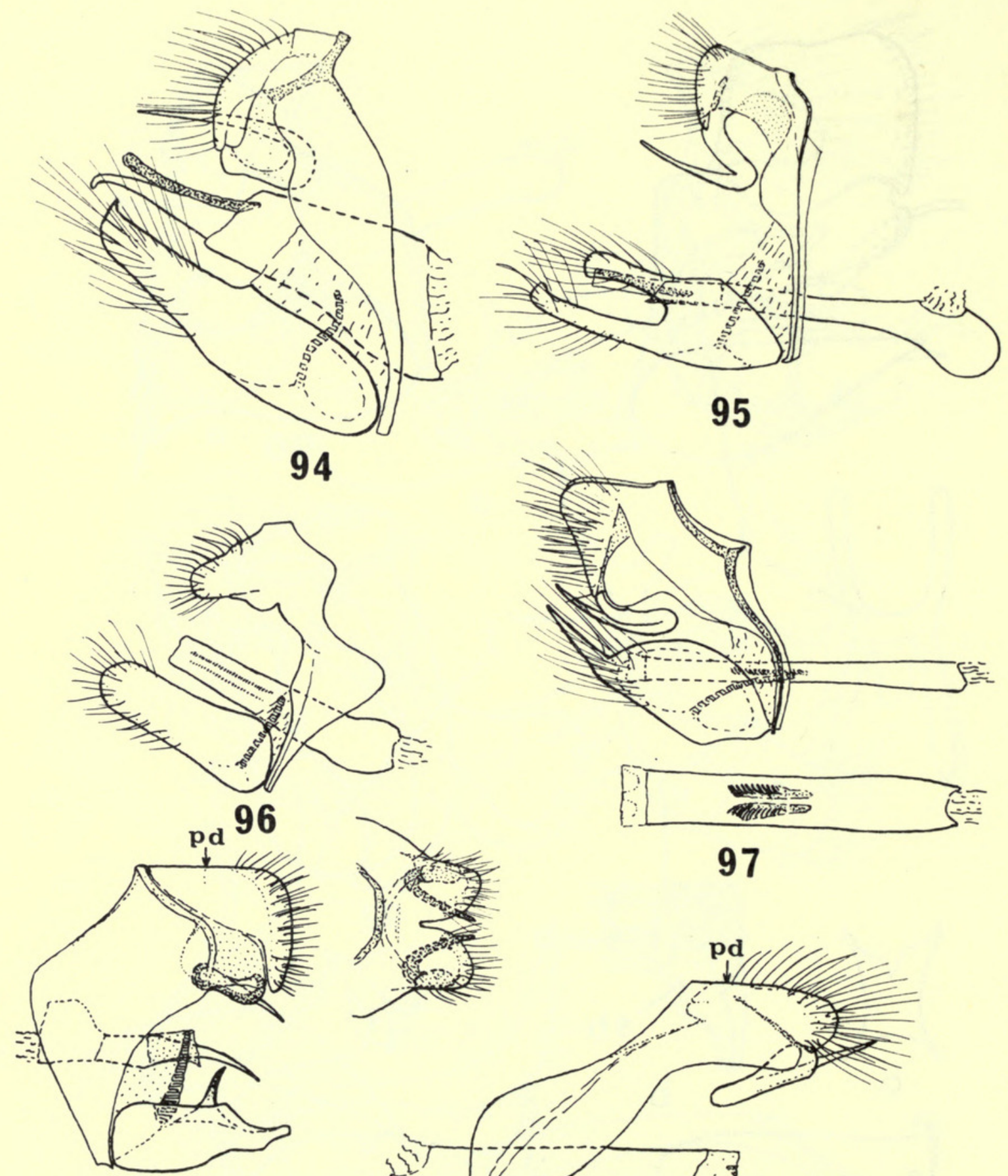

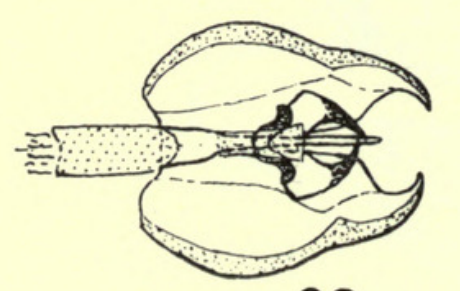

98

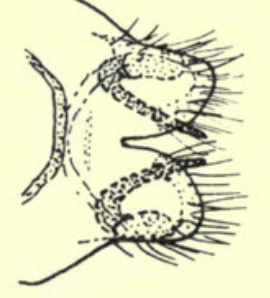

97

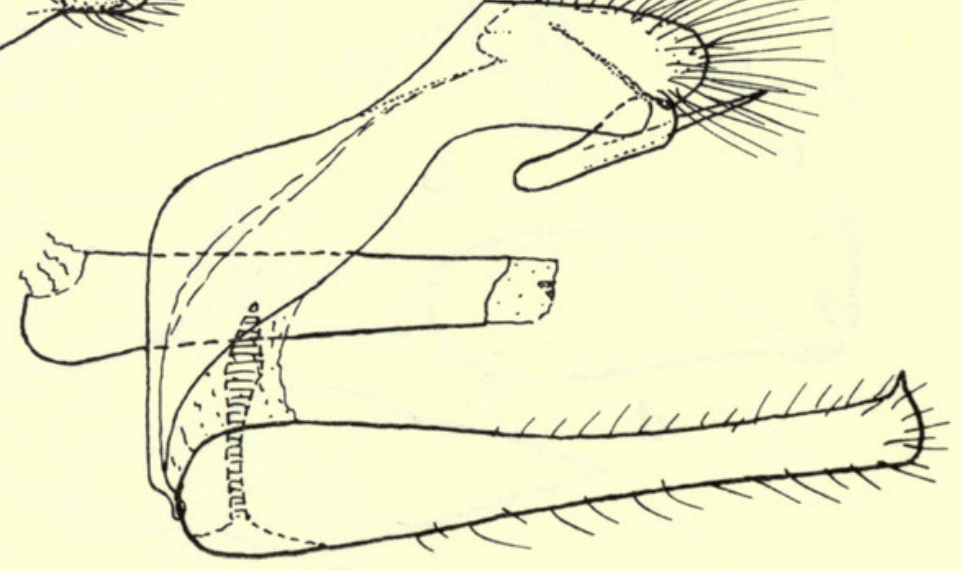

99

Figs 94-99. Male genitalia. 94. Danis danis (Cramer). 95. Jamides pura (Moore). 96. Rysops scintilla (Mabille). 97. Catochrysops panormus (Felder). 98. Theclinesthes serpentata (Herrich-Schäffer) comb. n., armature and, right, dorsal view of dorsum; below, dorsal view of valvae + juxta + penis. 99. Phlyaria cyara (Hewitson). 

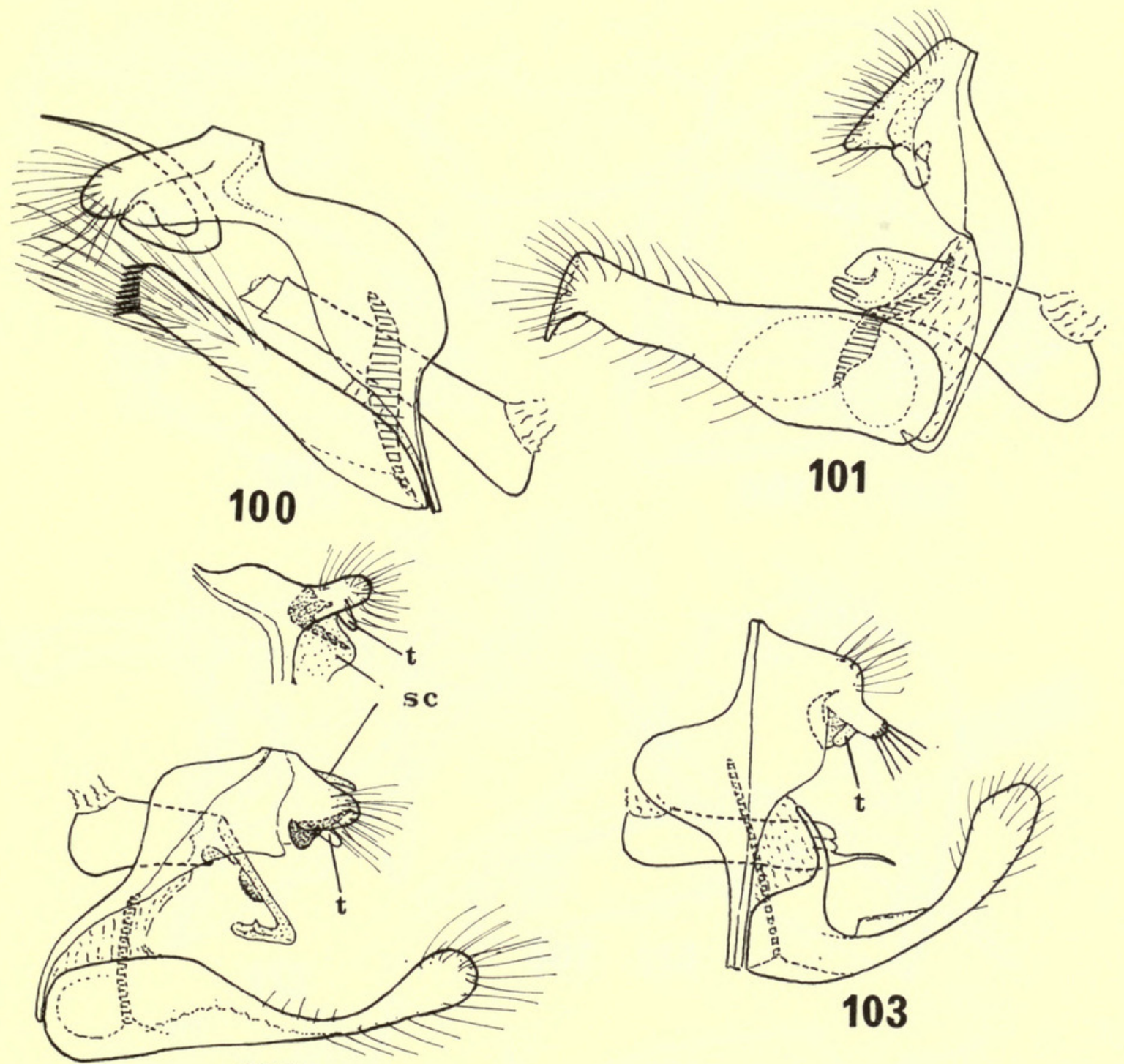

103

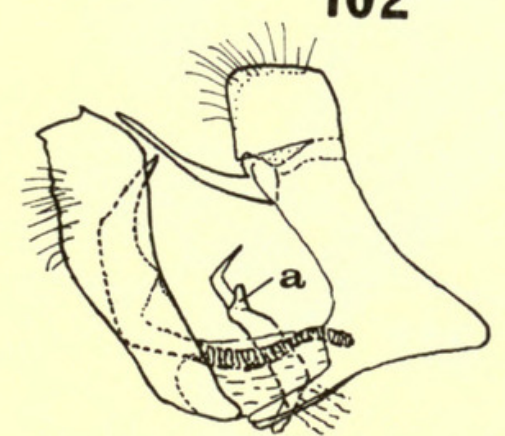

104

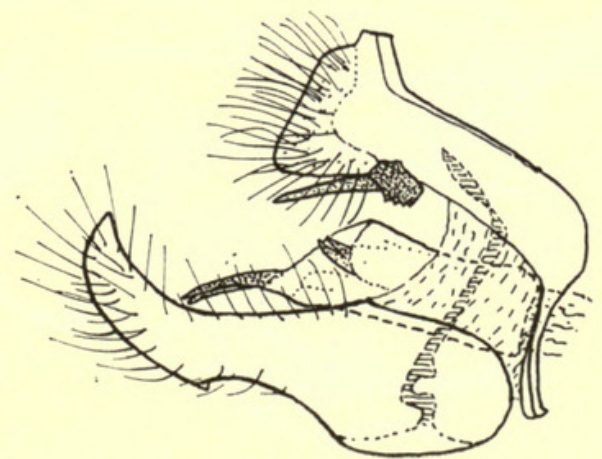

105

FIGS I00-105. Male genitalia. Iоo. Uvanothauma antinorii (Oberthür). Ior. Lampides boeticus (L.). I02. Cacyreus lingeus (Cramer). I03. Harpendyreus tsomo (Trimen). I04. 'Castalius' melaena (Trimen), armature and, right, dorsal view of penis. I05. Leptotes cassius (Cramer). 

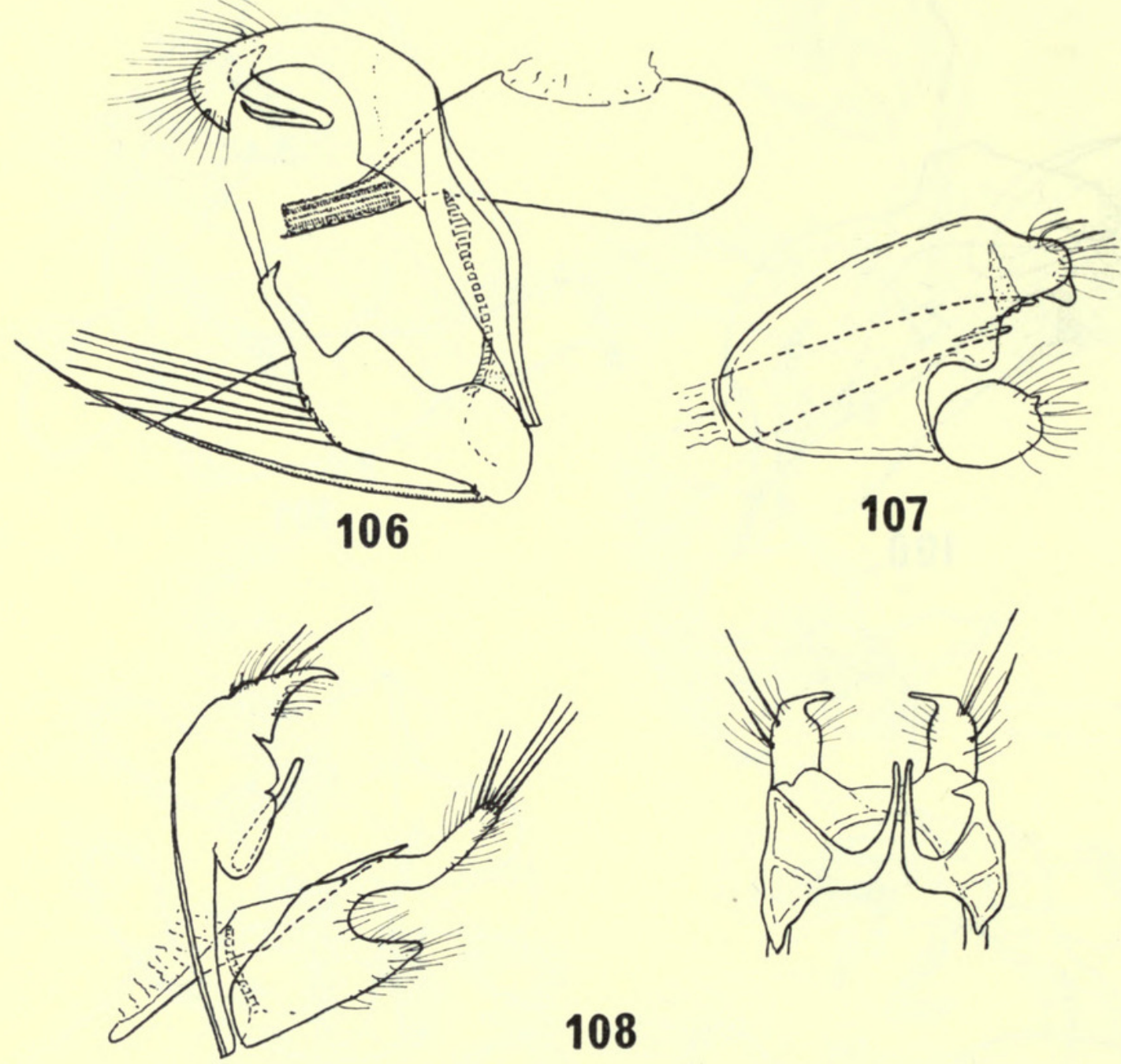

\section{8}

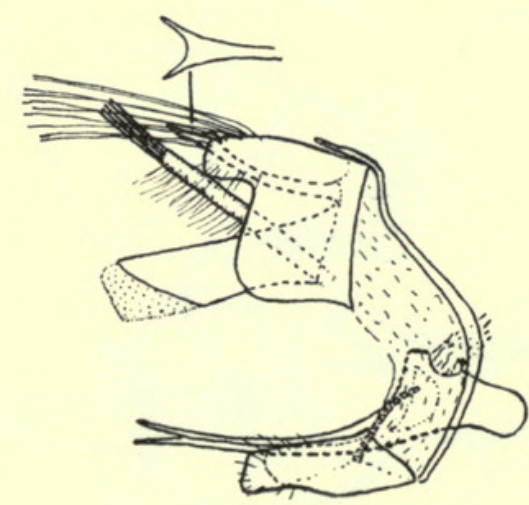

109

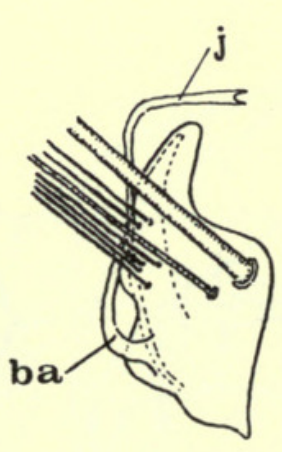

110

Figs 106-I 10. Male genitalia. 106. Zizina otis labradus (Godart). 107. Zintha hintza (Trimen). I08. Famegana alsulus (Herrich-Schäffer), armature and, right, ventral view of dorsum. I09. Oraidium barbarae (Trimen). r ro. Zizula hylax (Fabricius), armature and, left, enlargement of valva + juxta. 

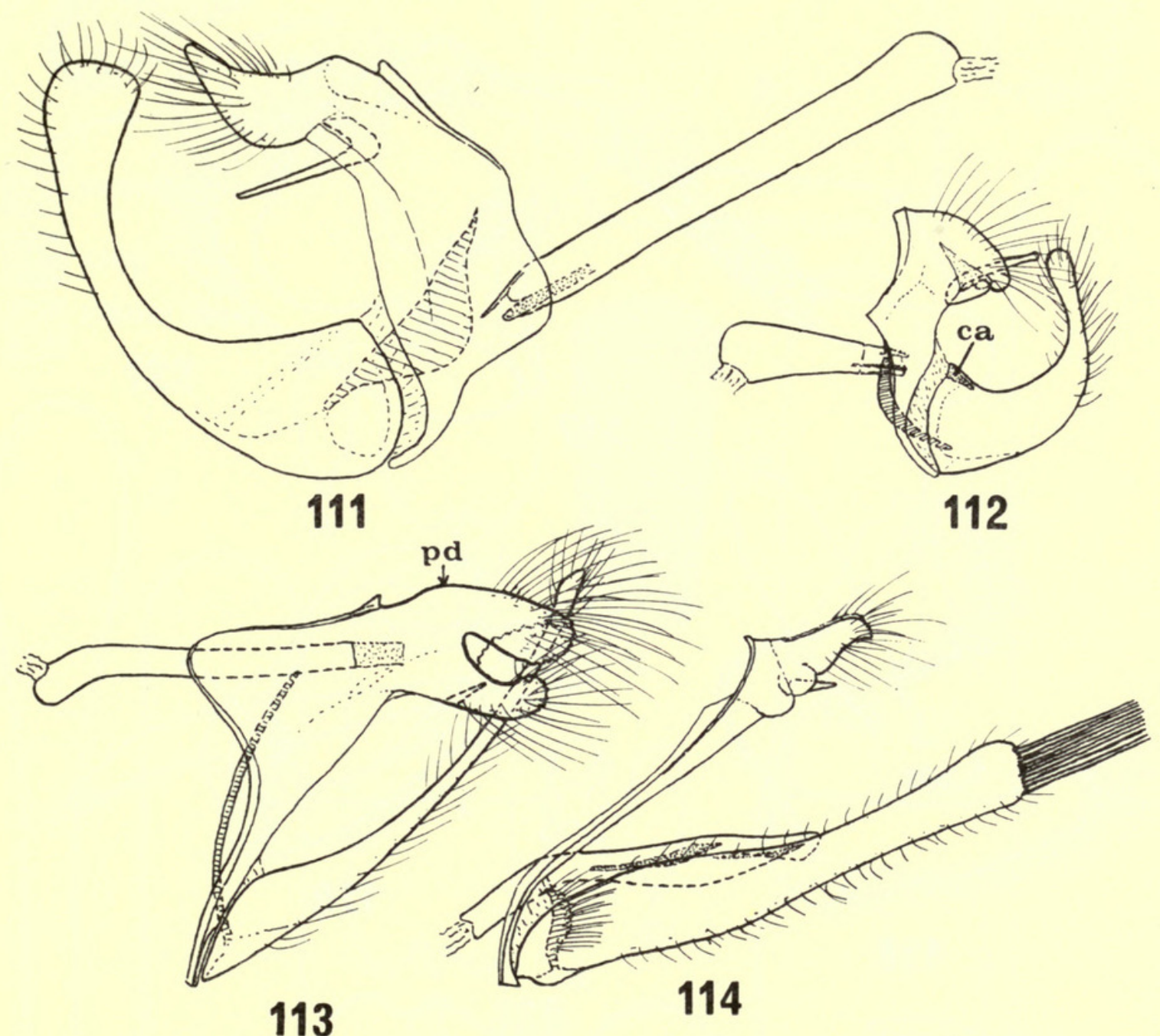

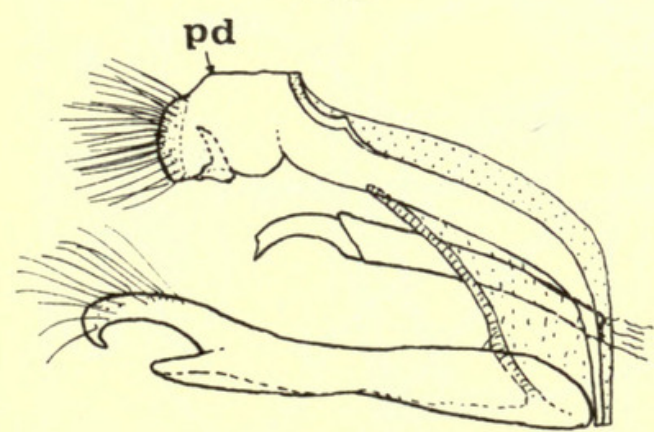

115

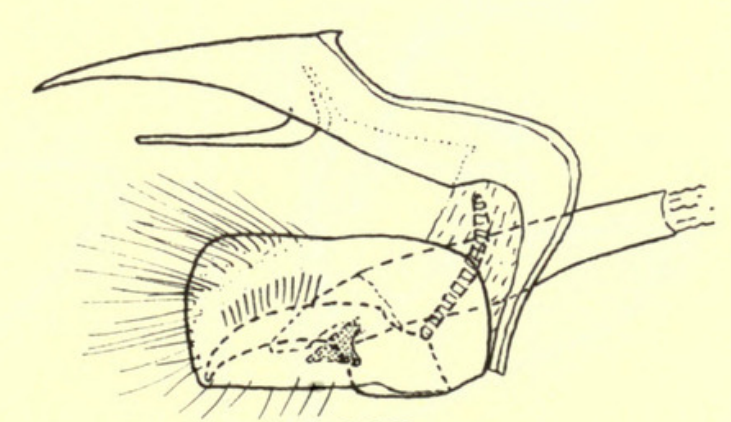

116

Figs iII-II6. Male genitalia. III. Actizera stellata (Trimen), much enlarged compared with text-fig. II2. II2. Actizera lucida (Trimen). II3. Eicochrysops mahallakoena (Wallengren). II4. Azanus jesous (Guérin-Méneville). II5. Pithecops corvus Fruhstorfer. II6. Talicada nyseus (Guérin-Méneville). 


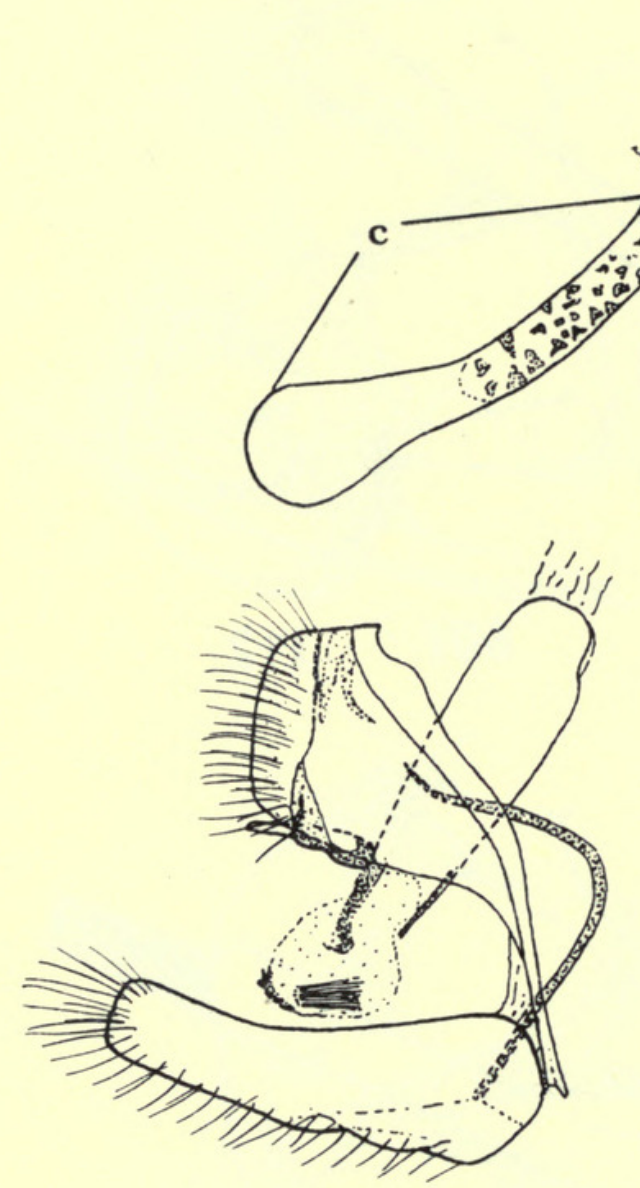

118
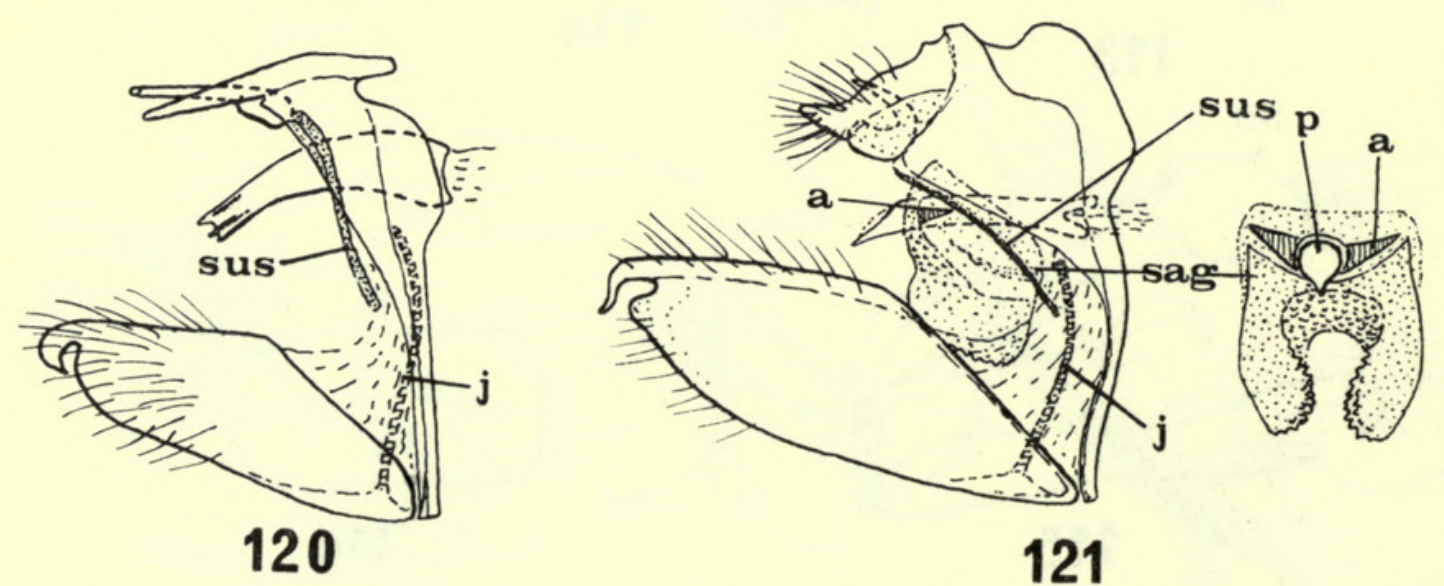

Figs II7-I2I. Male genitalia. II7. Rhinelephas arrhina Toxopeus. II8. Scolitantides orion (Pallas). I 19. Euchrysops cnejus (Fabricius). I20. Chilades laius (Cramer). I2I. Pseudolucia chilensis (Blanchard). 


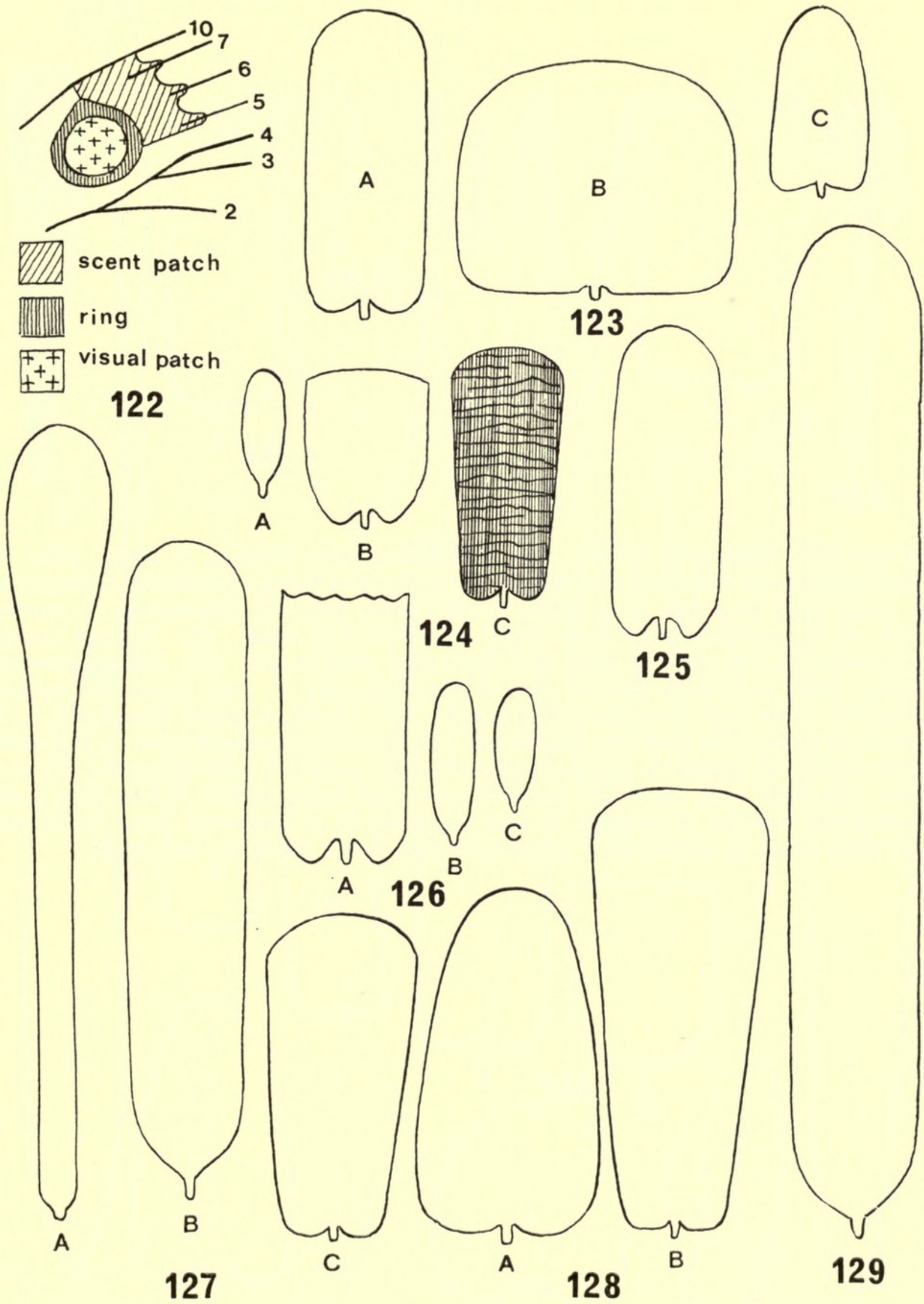

Figs I22-I29. Male wing brand and scales. I22. Fore wing brand of 'Thecla' bitias (Cramer). I23. Scales from brand of ' $T$ '. bitias. A, scale from visual patch; B, scale from ring; C, scent scale. 124. Catapaecilma elegans (H. Druce), A, scent scale from fore wing vein I; B, fuscous under-scale; C, purple top-scale. I25. Drupadia ravindra (Horsfield), presumed scent scale from hind wing brand. I26. Rapala iarbas (Fabricius), A, red top-scale; B, scent scale from fore wing vein 4 ; C, scent scale from hind wing brand. I27. Micandra platypteva (Felder), A, pale blue scale from fore wing brand; B, fuscous scale from fore wing brand; C, blue top-scale. I28. Trichonis theanus (Cramer), A, presumed scent scale from hind wing brand; B, blue top-scale. I29. Purlisa giganteus (Distant), presumed scent scale from abdominal brand. 
FIgS 130-138. Male wing scales. 130. Drina discophora (Felder), A, scent scale; B, short plume scale from fore wing brand. I3I. Tomares ballus (Fabricius), A, top-scale; B, scent scale from fore wing brand. I32. Pentila tropicalis (Boisduval), A, normal scale; B, C, modified scales from under surface of fore wing. I33. Aslanga vininga (Hewitson), A, top-scale; B, scent scale from hind wing brand. I34. Miletus chinensis Felder, scent scale from swollen part of fore wing vein 4. 135. Hemiolaus coeculus (Hopffer), scent scale from hind wing brand. 136. Dacalana vidura (Horsfield), A, B, presumed scent scales from fore wing brand. I37. Poritia erycinoides (Felder), A, B, C, scales from abdominal brand, A, being a presumed scent scale; $\mathrm{D}$, blue top-scale; $\mathrm{E}$, scent scale from hind wing brand; F, polished scale from under surface of fore wing. I38. Aethiopana honorius (Fabricius), A, blue top-scale; B, C, presumed scent scales from fore wing veins; $\mathrm{D}$, specialized (? scent) scale from vein I above the hair fringe. 


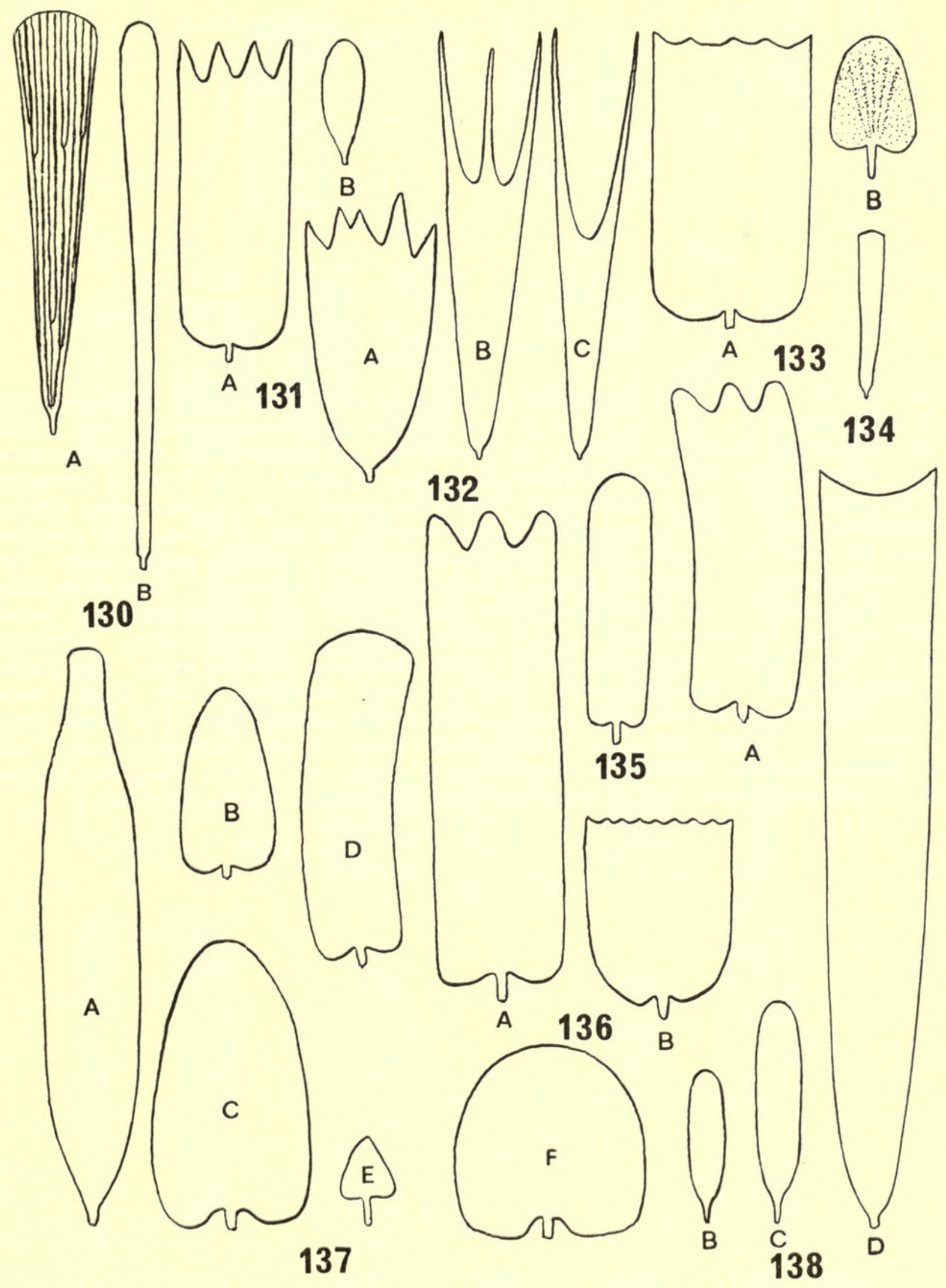


Figs I39-I62. Male wing scales. I39. Rysops scintilla (Mabille), A, blue top-scale; B, battledore scale. I40. Catochrysops strabo (Fabricius), battledore scale. I4I. Zizina otis (Fabricius), battledore scales. I42. Brephidium exilis (Boisduval), battledore scale. I43. Zizeeria maha (Kollar), battledore scale. I44. Actizera lucida (Trimen), battledore scale. I45. Itylos moza (Staudinger), battledore scales. I46. Azanus mirza (Plotz), battledore scale. I47. Agrodiaetus ripartii (Freyer), battledore scale. I48. Petrelaea dana (de Nicéville), paddle scale. I49. Azanus ubaldus (Cramer), paddle scale. I50. Freyeria trochylus (Freyer), A, brown top-scale; B, gelbe schuppe; C, battledore scale. I5I. Upolampes evena (Hewitson), battledore scale. I52. Pseudonacaduba sichela (Wallengren), battledore scale. I53. Famegana alsulus (Herrich-Schäffer), battledore scale. I54. Psychonotis purpurea (H. H. Druce) comb. n., battledore scale. 155. Zintha hintza (Trimen), battledore scale. 156. 'Holochila' absimilis Felder, dagger scale. I57. Uvanothauma antinorii (Oberthür), modified short plume scale. I58. Danis danis (Cramer), battledore scale. I59. Theclinesthes miskini (Lucas), battledore scale. I6o. Niphanda tessellata Moore, 'hieroglyphically-marked' scale. r6r. Lampides boeticus (L.), androconial scale. I62. Uvanothauma nubifer (Trimen), short plume scale. 


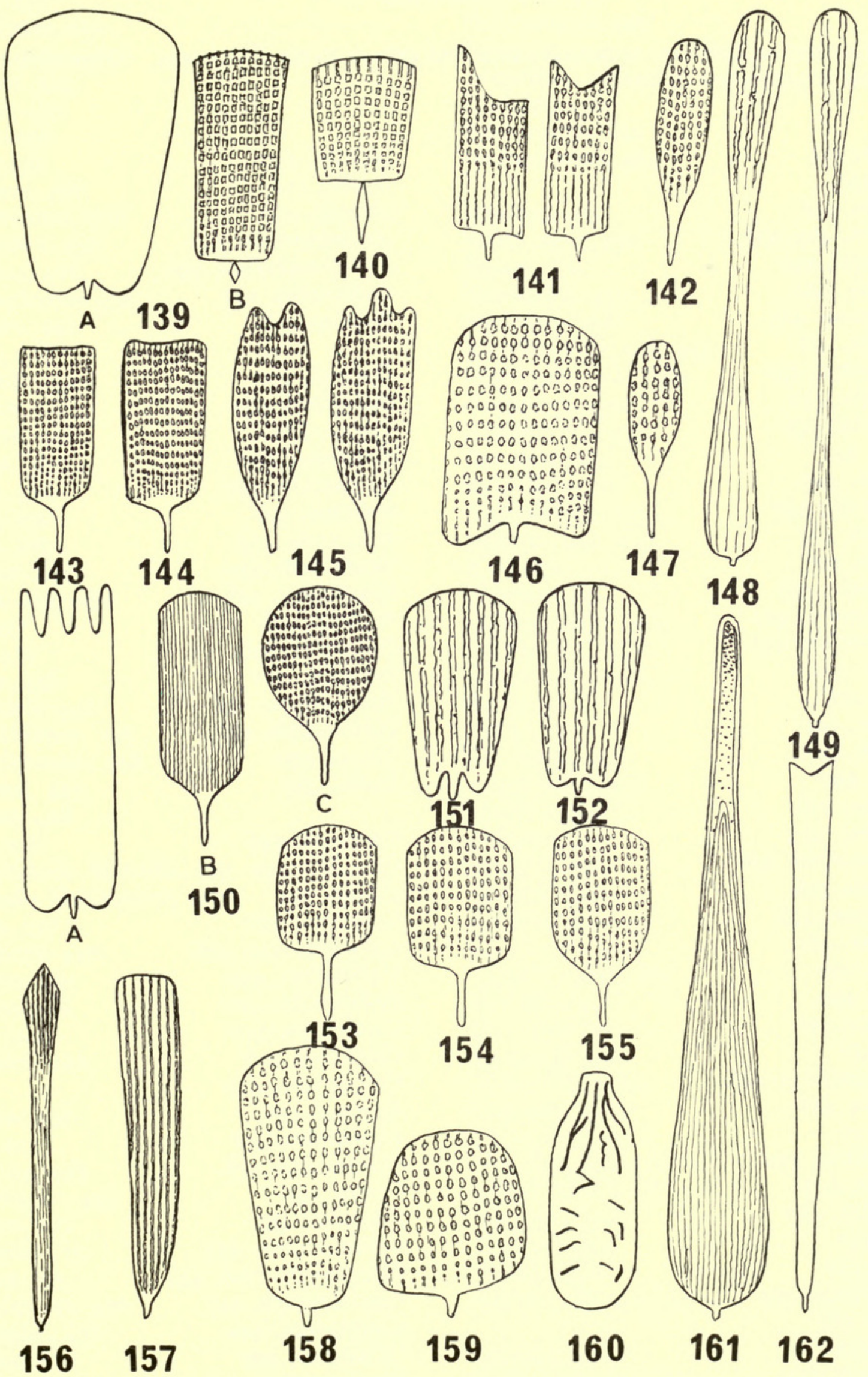




\section{IN DEX}

Index to the subfamilies, tribes and included genera in the Diagnoses. Objective synonyms and invalid names are in italics.

Acesina, 43I

Actis, 439

Actizera, 447

Acupicta, 433, 45I

Acytolepis, 449

Adaluma, 442

Aethiopana, 425

Agriades, 450

Agrodiaetus, $45^{\circ}$

Ahlbergia, 440

Akasinula, 449

Alaena, 423

Albulina, 450

Allosmaitia, 440

Allotinus, 427

Aloeides, 436

Amblopala, 430

Amblyopodia, 432

Amblypodiini, 432

Ancema, 438

Anops, 428

Anthene, $44^{2}$

Antigius, 430

Apelles, 449

Apharitis, 436

Aphnaeini, 435

Aphnaemorpha, 436

Aphnaeus, 436

Aphniolaus, 437

Apporasa, 43I

Araotes, 439

Araragi, 430

Arawacus, $44^{\circ}$

Arcas, 440

Archaeogerydus, 426

Argiolaus, 437

Argus, 440

Argyrocheila, 424

Arhopala, 43I

Arhopalini, 430

Aricia, 450

Arletta, 449

Arrhenothrix, 437

Arrugia, 428

Artipe, 439

Artopoetes, 430

Aslauga, 426

Athysanota, 449
Atlides, $44^{\circ}$

Aurea, 43I

Aurotis, 430

Austromyrina, 432

Austrozephyrus, 430

Axiocerces, 436

Azanus, 448

Bakeria, 440

Baliochila, 424

Baspa, 439

Batelusia, 425

Bergmania, 430

Bidaspa, 439

Biduanda, 435

Bindahara, 439

Binghamia, 448

Bothria, $44^{8}$

Bothrinia, $44^{8}$

Brangas, $44^{\circ}$

Brephidium, 448

Britomartis, 437

Bryna, $45^{\circ}$

Bullis, 437

Cacyreus, 446

Caerulea, 449

Caleta, 444

Callicista, $44^{\circ}$

Callictita, 445, 446

Callipareus, 440

Callipsyche, $44^{\circ}$

Callophrys, $44^{\circ}$

Calycopis, $44^{\circ}$

Calystryma, $44^{\circ}$

Camena, $43^{8}$

Candalides, 442

Candalidini, 442

Capys, 439

Castalius, 447

Catapaecilma, 433

Catapaecilmatini, 432

Catochrysops, 445

Catopyrops, 444

Celastrina, 449

Chaetoprocta, 430

Chalceria, $44^{\circ}$

Chalybs, $44^{\circ}$ 
Charana, 437

Chattendenia, $44^{\circ}$

Cheritra, 435

Cheritrella, 435

Cheritrini, 435

Chilades, $45^{\circ}$

Chliaria, $43^{8}$

Chloroselas, 436

Chlorostrymon, 440

Chrysorychia, 436

Chrysoritis, 436

Chrysozephyrus, 430

Chysoptera, 44I

Cigaritis, 436

Citrinophila, 424

Cnodontes, 424

Cooksonia, 424

Cophanta, 437

Cordelia, 430

Coreana, 430

Corydon, 425

Cosmolyce, 445

Cowania, 435, $45^{\circ}$

Creon, 437

Creusa, 437

Crudaria, 436

Cupidesthes, 442

Cupido Hübner, 435

Cupido Schrank, 448

Cupidopsis, 443

Curetinae, 428

Curetis, 428

Cyaniriodes de Nicéville, 425

Cyaniriodes Matsumura, 449

Cyaniris, $45^{\circ}$

Cyanophrys, $44^{\circ}$

Cyclargus, $45^{\circ}$

Cyclyrius, 446

Cycnus, 440

Cyprotides, 442

Dacalana, 437

Damis, 445

Danis, 444, 445

Dapidodigma, 435

Darasana, 43I

Deloneura, 425

Deramas, 425

Desmolycaena, 436

Deudorigini, 438

Deudorix, 439

Diopetes, 439

Dipsas, 430

Discolampa, 444
Disparia, 44I

Dolymorpha, 440

Drina, 434

Drupadia, 435

Durbania, 424

Durbaniella, 424

Durbaniopsis, 424

Ebepius, 425

Echinargus, $45^{\circ}$

Edales, 450

Edwardsia, 440

Egumbia, 426

Eicochrysops, 448, 449

Electrostrymon, 440

Endymion, 440

Eooxylides, 434

Epamera, 437

Epidemia, 44I

Epimastidia, 445

Epitola, 424, 425

Epitolina, 425

Eresina, 424

Eresinopsides, 424

Eresiomera, 424

Erikssonia, 436

Erina, $44^{2}$

Erora, $44^{\circ}$

Erschoffia, 440

Erysichton, 444

Etesiolaus, 437

Ethion, 444

Euaspa, 430

Eucharia, $44^{\circ}$

Euchrysops, 449

Euliphyra, 426

Euliphyrodes, 426

Eumaea, 440

Eumaeini, 439

Eumaeus, $44^{\circ}$

Eumedonia, $45^{\circ}$

Eumenia, 440

Eupsyche, 440

Eupsychellus, $44^{8}$

Euristrymon, 440

Euthecta, 424

Evenus, 440

Everes, 448

Esakiozephyrus, 430

Falcuna, 424

Famegana, 447, 453

Favonius, 430

Felderia, $44^{\circ}$ 
Feniseca, 427

Fixsenia, 440

Flos, 43I

Freyeria, 450

Gaeides, 44I

Gerydus, 426

Ginzia, 440

Glaucopsyche, 449

Gonatomyrina, $43^{8}$

Gonerilia, 430

Gynomorphia, $45^{\circ}$

Habrodais, 430

Hadothera, 445

Harpendyreus, 446

Heliophorus, 44I

Helleia, 44I

Hemiargus, $45^{\circ}$

Hemiolaus, 437

Heodes, 44I

Heterosmaitia, 440

Hewitsonia, 425

Hirsutina, $45^{\circ}$

Holochila, $44^{2}$

Horaga, 435

Horagini, 434

Horsfieldia, 432

Howarthia, 430

Hypaurotis, 430

Hypochlorosis, 433

Hypochrysops, 429

Hypojamides, 444

Hypokopelates, 439

Hypolycaena, 438

Hypolycaenini, 438

Hypomyrina, 439

Hypophytala, 425

Hypostrymon, 440

Hypothecla, 433

Hypotheclini, 433

Hyrcanana, 44I

Hyreus, 446

Hysudra, 439

Iaspis, 440

Icaricia, $45^{\circ}$

Ilerda, 44I

Incisalia, 440

Indoxylides, 434

Iolaini, 436

Iolana, 449

Iolaphilus, 437

Iolaus, 436, 437
Ionolyce, 444

Iophanus, 44I

Ipidecla, $44^{\circ}$

Iraota, 432

Iratsume, 430

Iridana, 424

Iridopsis, 424

Iris, 424,

Itylos, $45^{\circ}$

Jacoona, 437

Jalmenus, 432

Jamides, 4I 5

Japonica, 430

Keraunogramma, 43I

Klugia, 440

Kollaria, 440

Kopelates, 439

Kretania, 450

Lachnocnema, 428

Lachnocnemini, 427

Laeosopis, 430

Lampidella, 445

Lampides, 445

Lamprospilus, 440

Larinopoda, 424

Lectiles, 424

Lehera, 439

Lepidochrysops, 449

Leptomyrina, 438

Leptotes, 446

Leucantigius, 430

Leucolepis, 424

Licus, $44^{\circ}$

Lipaphnaeus, 436

Liphyra, 426

Liphyrinae, 425

Liptena, 424

Liptenara, 423

Lipteninae, 422

Liptenini, 423

Listeria, 439

Logania, 427

Loweia, 44I

Loxura, 434

Loxurini, 433

Lucia, 429

Luciini, 429

Luthrodes, $45^{\circ}$

Lycaeides, $45^{\circ}$

Lycaena, 44I

Lycaenesthes, 442 
Lycaenesthini, 442

Lycaeninae, 44I

Lycaenopsis, 449

Lycia, 44I

Lycus, $44^{\circ}$

Lysandra, $45^{\circ}$

Maculinea, 449

Macusia, $44^{\circ}$

Mahathala, 43I

Malais, 427

Mambara, 444

Maneca, 437

Manto, 437

Mantoides, 437

Marshallia, 434

Massaga, 425

Megalopalpus, 427

Megisba, 449

Meleageria, $45^{\circ}$

Micandra, 44I

Micropentila, 424

Microscena, $44^{2}$

Migonitis, 44I

Miletinae, 426

Miletini, 426

Miletographa, 426

Miletus, 426

Mimacraea, 424

Mimeresia, 424

Ministrymon, $44^{\circ}$

Mithras, 440

Mitoura, 440

Molus, 440

Monile, $44^{2}$

Monodontides, 449

Moorea, 449

Mota, 43I

Myrina, 432

Nabokovia, $45^{\circ}$

Nacaduba, 444

Nadisepa, 439

Nais, 436

Narathura, 43I

Neaveia, 425

Neocheritra, 437

Neochrysops, 449

Neoepitola, 425

Neolucia, 444

Neolycaena, $44^{\circ}$

Neomyrina, 434

Neopithecops, 449

Neozephyrus, 430
Nesiostrymon, $44^{\circ}$

Nesolycaena, $44^{2}$

Neurellipes, 442

Neurypexina, 442

Nilasera, 43I

Niphanda, 443

Niphandini, 442

Nomiades, $45^{\circ}$

Nordmannia, $44^{\circ}$

Notarthrinus, 449

Oboronia, 449

Oenomaus, $44^{\circ}$

Ogyrini, 43I

Ogyris, 43I

Olynthus, 440

Ops, 437

Oraidium, 448

Oreolyce, 449

Ornipholidotos, 423

Orthomiella, 443

Oxylides, 433

Oxylidini, 433

Paiwarria, 440

Palaeochrysophanus, 44I

Palaeoloweia, 44I

Palaeophilotes, 449

Pamela, 439

Panchala, 43I

Panthiades, $44^{\circ}$

Рариа, 449

Parachilades, $45^{\circ}$

Parachrysops, 429

Paraduba, 444

Paragerydus, 426

Paralucia, 429

Paralycaeides, $45^{\circ}$

Paraphnaeus, 436

Parapithecops, 449

Paraslauga, 426

Parelodina, 449

Parrhasius, $44^{\circ}$

Pathalia, 449

Pentila, 423

Pentilini, 423

Pepliphorus, 445

Peplodyta, 445

Petrelaea, 444

Phaedra, 428

Phaedrotes, 449

Phaeostrymon, $44^{\circ}$

Phasis, 436

Phengaris, 449 
Philiolaus, 437

Philiris, 429

Philotes, 449

Phlyaria, 446

Phoenicurusia, 44I

Phytala, 425

Pilodeudorix, 439

Pistoria, 444

Pithecops, $44^{8}$

Plebejus, $45^{\circ}$

Plebicula, $45^{\circ}$

Plebulina, 450

Poecilmitis, 436

Polyniphes, 440

Polyommatinae, 44I

Polyommatini, 443

Polyommatus, 449, 450

Poriskina, 425

Poritia, 425

Poritiinae, 425

Poultonia, 425

Powellana, 425

Praephilotes, 449

Pratapa, 437

Prosotas, 444

Protantigius, 430

Protialmenus, 432

Pseudaletis, 436

Pseudalmenus, 432

Pseuderesia, 424

Pseudiolaus, 437

Pseudoaricia, 450

Pseudocapys, 436

Pseudochliaria, 439

Pseudochrysops, $45^{\circ}$

Pseudodipsas, 429

Pseudolucia, 450

Pseudolycaena, 440

Pseudomyrina, 437

Pseudonacaduba, 444

Pseudoneaveia, 425

Pseudonotis, 433

Pseudophilotes, 449

Pseudotajuria, 438, 45I

Pseudothecla, Nabokov $45^{\circ}$

Pseudothecla Strand, $44^{\circ}$

Pseudozizeeria, 447

Psychonotis, 445

Ptelina, 423

Ptox, 449

Purlisa, 437

Pycnophallium, 444

Quercusia, 430
Rapala, 439

Rathinda, 435

Ravenna, 430

Rekoa, 440

Remelana, 438

Remelanini, 437

Rhinelephas, 449

Ritra, 435

Rumicia, 44I

Ruralis, 430

Rysops, 445, $45^{2}$

Sandia, $44^{\circ}$

Sarthusia, 44I

Satadra, 43I

Satsuma, $44^{\circ}$

Satyrium, 440

Scolitantides, 449

Scoptes, 439

Semanga, 43I

Sheffieldia, 424

Shijimia, 448

Shijimiaeoides, 449

Shirozua, 430

Siderus, 440

Simiskina, 425

Sinia, 449

Sinthusa, 439

Sithon, 439

Spalgini, 427

Spalgis, 427

Spindasis, 436

Stempfferia, 425

Sterosis, 426

Strymon, 440

Strymonidia, 440

Stugeta, 437

Suasa, 437

Sukidion, 437

Superflua, 440

Surendra, 43I

Symbiopsis, 440

Symetha, 426

Syntarucoides, 446

Syntarucus, 446

Syrmoptera, 433

Tajuria, 437

Talicada, 448

Tanuetheira, 437

Taraka, Doherty 427

Taraka, de Nicéville, 427

Tarakini, 427

Tarucus, 447 
Tatura, $43^{8}$

Telipna, 423

Teratoneura, 424

Teratozephyrus, 430

Teriomima, 424

Tetrarhanis, 424

Thaduka, 43I

Thamala, 434

Tharsalea, 44I

Thaumaina, 444

Thecla, 430

Theclinae, 428

Theclinesthes, 444

Theclini, 429

Thecliolia, 440

Theclopsis, 440

Theorema, $44^{\circ}$

Thereus, $44^{\circ}$

Theritas, 440

Thermoniphas, 449

Thersamonia, 44I

Thestius, 440

Thestor, 428

Thestorinae Clench, 427

Thestoridi Tutt, 427, 439

Thrix, 437

Thysonotis, 445

Ticherra, 435

Tiora, 448

Titea, 429, $45^{2}$

Tmolus, $44^{\circ}$

Tomares, 439

Tomarini, 439

Tongeia, $44^{8}$

Toxochitona, 424

Trichiolaus, 437

Trichonis, 44I

Triclema, 442

Tumerepedes, 425

Turanana, 449

Turania, 449
Tuttiola, $44^{\circ}$

Udara, 449

Ultraaricia, $45^{\circ}$

Una, 443

Ununcula, $44^{8}$

Upolampes, 444

Uranobothria, 449

Uranops, $45^{\circ}$

Uranotes, $44^{\circ}$

Uranothauma, 446

Ussuriana, 430

Utica, 444

Vacciniina, $45^{\circ}$

Vadebra, 439

Vaga, 449

Virachola, 439

Virgarina, 437

Wagimo, 430

Waigeum, 429

Xamia, $44^{\circ}$

Yasoda, 434

Zarona, 425

Zeltus, $43^{8}$

Zephyrus, 430

Zeritis, 436

Zerythis, 436

Zesiini, 43I

Zesius, 432

Zetona, 442

Zinaspa, 43I

Zintha, 447, 453

Zizeeria, 447

Zizera, $44^{8}$

Zizina, 447

Zizula, 447, $44^{8}$

Lt. Col. J. N. Eliot

Upcott House

Bishop's Hull

TAUNTON

SOMERSET 


\section{$2 \mathrm{BHL}$ Biodiversity Heritage Library}

Eliot, John Nevill. 1973. "The higher classification of the Lycaenidae (Lepidoptera): a tentative arrangement." Bulletin of the British Museum (Natural History) Entomology 28, 371-505.

https://doi.org/10.5962/bhl.part.11171.

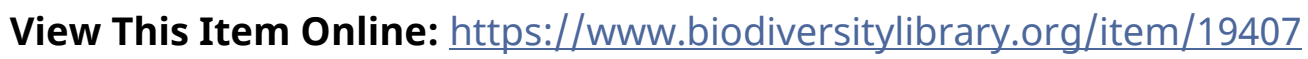

DOI: https://doi.org/10.5962/bhl.part.11171

Permalink: https://www.biodiversitylibrary.org/partpdf/11171

\section{Holding Institution}

Natural History Museum Library, London

\section{Sponsored by}

Natural History Museum Library, London

\section{Copyright \& Reuse}

Copyright Status: In copyright. Digitized with the permission of the rights holder.

Rights Holder: The Trustees of the Natural History Museum, London

License: http://creativecommons.org/licenses/by-nc-sa/4.0/

Rights: http://biodiversitylibrary.org/permissions

This document was created from content at the Biodiversity Heritage Library, the world's largest open access digital library for biodiversity literature and archives. Visit BHL at https://www.biodiversitylibrary.org. 